\title{
MONOGRAPH OF THE FAMILY MORDELLIDAE (COLEOPTERA) OF NORTH AMERICA, NORTH OF MEXICO
}

BY

EMIL LILJEBLAD

\author{
ANN ARBOR \\ UNIVERSITY OF MICHIGAN PRESS \\ DeCEMBer 24, 1945
}




\section{PRICE LIST OF THE MISCELLANEOUS PUBLICATIONS OF THE MUSEUM OF ZOOLOGY, UNIVERSITY OF MICHIGAN}

Address inquiries to the Director of the Museum of Zoology, Ann Arbor, Michigan.

\section{Bound in Paper}

No. 1. Directions for Collecting and Preserving Specimens of Dragonflies for Museum Purposes. By E. B. Williamson. (1916) Pp. 15, 3 figures

No. 2. An Annotated List of the Odonata of Indiana. By E. B. Williamson. (1917) Pp. 12, 1 map

No. 3. A Collecting Trip to Colombia, South America. By E. B. Williamson. (1918) Pp. 24. (Out of print)

No. 4. Contributions to the Botany of Michigan. By C. K. DoDGE. (1918) Pp. 14

No. 5. Contributions to the Botany of Michigan, II. By C. K. DoDGE. (1918) Pp. 44, 1 map

No. 6. A Synopsis of the Classification of the Freshwater Mollusca of North America, North of Mexico, and a Catalogue of the More Recently Described species, with Notes. By Bryant Walkme. (1918) Pp. 213 , 1 plate, 223 figures

No. 7. The Anculosae of the Alabama River Drainage. By CaLvin Goodrich. (1922) Pp. 57, 3 plates

No. 8. The Amphibians and Reptiles of the Sierra Nevada de Santa Marta, Colombia. By Alexander G. Ruthren. (1922) Pp. 69, 13 plates, 2 figures, 1 map

No. 9. Notes on American Species of Triacanthagyna and Gynacantha. By E. B. Williamson. (1923) Pp. 67, 7 plates

No. 10. A Preliminary Survey of the Bird Life of North Dakota. By NormaN A. Wood. (1923) Pp. 85, 6 plates, 1 map ...............................................

No. 11. Notes on the Genus Erythemis, with a Description of a Now Species (Odonata). By E. B. Williamson.

The Phylogeny and the Distribution of the Genus Erythemis (Odonata). By CLARENCE H. KeNNEDY. (1923) Pp. 21, 1 plate ................................... $\$ 0.50$

No. 12. The Genus Gyrotoma. By CALviN GoodricH. . (1924) Pp. 29, 2 plates ... $\$ 0.50$

No. 13. Studies of the Fishes of the Order Cyprinodontes. By CARL L. HUBBs. (1924) Pp. 23, 4 plates

No. 14. The Genus Perilestes (Odonata). By E. B. Williamson aND J. H. WIL-

NIIMSON. (1924) Pp. 36, 1 plate .................................................................... with Nomenclatorial Notes and Analytical Keys. By CARI L. HUBBS. (1926) Pp. 77, 4 plates

No. 16. Studies of the Fishes of the Order Cyprinodontes. VI. By CARL L. HUBBs. (1926) Pp. 79, 4 plates ……...................................................

No.17. The Structure and Growth of the Scales of Fishes in Relation to the Interpretation of their Life-History, with Special Reference to the Sunfish Eupomotis gibbosus. By Charles W. Creaser. (1926) Pp. 80, 1 plate, 12 figures

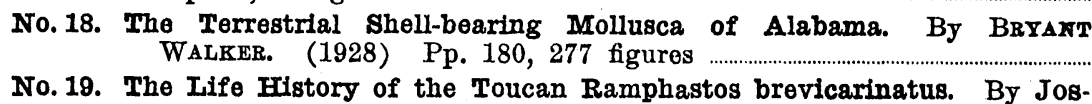

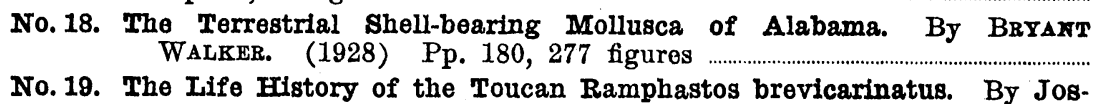
SELYN VAN TYNe. (1929) Pp. 43, 8 plates, 1 map ..............................

No. 20. Materials for a Revision of the Catostomid Fishes of Eastern North America. By CARL L. HUBBs. (1930) Pp. 47, 1 plate ...............................

No. 21. A Revision of the Libelluline Genus Perithemis (Odonata). By F. Ris. (1930) Pp. 50, 9 plates

No. 22. The Genus Oligoclada (Odonata). By Donald J. Borror. (1931) Pp. 42,7 plates

No. 23. A Revision of the Puer Group of the North American Genus, Melanoplus, with Remarks on the Taxonomic Value of the Concealed Male Genitalia in the Oyrtacanthacrinae (Orthoptera, Acrididae). By TreoDORE H. HUBBELL. (1932) Pp. 64, 3 plates, 1 figure, 1 map 



\section{ADVERTISEMENT}

The publications of the Museum of Zoology, University of Michigan, consist of two series-the Occasional Papers and the Miscellaneous Publications. Both series were founded by Dr. Bryant Walker, Mr. Bradshaw H. Swales, and Dr. W. W. Newcomb.

The Occasional Papers, publication of which was begun in 1913, serve as a medium for original papers based principally upon the collections of the Museum. The papers are issued separately to libraries and specialists, and, when a sufficient number of pages have been printed to make a volume, a title page, table of contents, and index are supplied to libraries and individuals on the mailing list for the entire series.

The Miscellaneous Publications, which include papers on field and museum techniques, monographic studies, and other contributions not within the scope of the Occasional Papers, are published separately, and as it is not intended that they will be grouped into volumes, each number has a title page.

Frederick M. Gaige Director of the Museum of Zoology 


\section{MONOGRAPH OF THE FAMILY MORDELLIDAE (COLEOPTERA) OF NORTH AMERICA, NORTH OF MEXICO}

BY

EMIL LILJEBLAD 


$$
\cdot
$$




\section{CONTENTS}

PAGE

INTRODUCTION

The Mordellidae

Glipodes Leconte

Conalia Mulsant and Rey

16

Isotrilophus, New Genus

18

Glipa Leconte

Mordella Linnaeus

20

Tomoxia Costa

Mordellistena Costa

Mordellistena Costa

Diclidia Leconte

187

Pentaria Mulsant

196

Naucles Champion

202

Sphingocephalus, New Genus

206

Anaspis Geoffroy

207

Silaria Mulsant

219

Larisia Emery

220

Nassipa Emery

222

BIBLIOGRAPHY

224

Index of Genera ANd Species 



\section{ILLUSTRATIONS}

(Plates I-VII follow page 226)

PLATE

I. FIG. 1. Position of the carinated ridges on the posterior legs in the subfamily Mordellini.

FIG. 2. Glipodes sericans Melsheimer, male.

FIG. 3. Conalia helva Leconte.

FIG. 4. Isotrilophus erratica Smith, male.

FIG. 5. Glipa hilaris Say, male.

FIG. 6. Glipa oculata Say.

FIG. 7. Glipa octopunctata Fabricius.

FIG. 8. Glipa bidentata Say.

II. FIG. 1. Glipa inflammata Leconte.

FIG. 2. Glipa perlineata Fall.

FIG. 3. Mordella knulli Liljeblad.

Fig. 4. Mordella signata Champion.

FIG. 5. Mordella schwarzi, new species.

FIG. 6. Mordella quadripunctata Say.

FIG. 7. Mordella lunulata Helmuth.

FIg. 8. Mordella obliqua Leconte.

FIG. 9. Mordella melaena Germar.

FIG. 10. Mordella brevistylis Liljeblad.

III. FIG. 1. Tomoxia serval Say.

FIG. 2. Mordella insulata Leconte.

FIG. 3. Mordella marginata Melsheimer.

FIG. 4. Mordella marginata Melsheimer.

FIG. 5. Mordella cinereoatra, new species.

FIG. 6. Mordella atrata Melsheimer.

FIG. 7. Mordella angulata Leconte.

FIG. 8. Mordella deserta Casey, elytra.

FIG. 9. Mordella albosuturalis Liljeblad.

FIG. 10. Mordella hubbsi Liljeblad.

FIG. 11. Mordella grandis Liljeblad.

FIG. 12. Mordella invisitata, new species.

FIG. 13. Tomoxia inclusa Leconte.

FIG. 14. Tomoxia borealis Leconte.

FIG. 15. Tomoxia fascifera Leconte.

FIG. 16. Tomoxia lineella Leconte.

FIG. 17. Tomoxia undulata Melsheimer.

FIG. 18. Tomoxia discoidea Melsheimer.

FIG. 19. Tomoxia triloba Say.

FIG. 20. Mordella carinata Smith.

IV. FIG. 1. Mordellistena frosti Liljeblad.

FIG. 2. Mordellistena arida Leconte.

FIG. 3. Mordellistena bicinctella Leconte.

FIG. 4. Mordellistena tarsalis Smith, elytra. 
FIG. 5. Mordellistena vilis Leconte.

FIg. 6. Mordellistena pauxilla, new species.

FIg. 7. Mordellistena vapida Leconte.

FIG. 8. Mordellistena intermixta Helmuth.

Fig. 9. Mordellistena trifasciata Say.

FIG. 10. Mordellistena sexnotata Dury.

Fig. 11. Mordellistena scapularis Say.

FIG. 12. Mordellistena limbalis Melsheimer.

Fig. 13. Mordellistena dimidiata Helmuth.

FIG. 14. Mordellistena nebulosa, new species.

Fig. 15. Mordellistena ornata Melsheimer.

FIG. 16. Mordellistena argenteola, new species.

FIg. 17. Mordellistena syntaenia Liljeblad.

Fig. 18. Mordellistena egregia, new species.

FIg. 19. Mordellistena comata Leconte.

FIG. 20. Mordellistena cervicalis Leconte.

FIg. 21. Mordellistena aspersa Melsheimer.

FIG. 22. Mordellistena rufilabris, new species.

Fig. 23. Mordellistena rubrilabris Helmuth.

Fig. 24. Mordellistena pullata, new species.

V. Fig. 1. Mordellistena minuta Smith.

FIG. 2. Mordellistena picilabris Helmuth.

FIG. 3. Mordellistena minutalis, new species.

FIg. 4. Mordellistena infima Leconte.

FIg. 5. Mordellistena andreae var. andreae Leconte, male.

FIG. 6. Mordellistena andreae var. andreae Leconte, female.

FIG. 7. Mordellistena andreae var. ancilla Leconte, male.

FIg. 8. Mordellistena andreae var. ancilla Leconte, female.

Fig. 9. Mordellistena andreae var. ustulata Leconte.

FIG. 10. Mordellistena semiusta Leconte.

FIG. 11. Mordellistena guttulata Helmuth.

FIG. 12. Mordellistena nigricans Melsheimer.

FIG. 13. Mordellistena parva, new species.

Fig. 14. Mordellistena subfucus, new species.

FIG. 15. Mordellistena wickhami, new species.

FIG. 16. Mordellistena ruficeps Leconte.

FIG. 17. Mordellistena floridensis Smith.

FIg. 18. Mordellistena blandula, new species.

Fig. 19. Mordellistena tantula, new species.

FIG. 20. Mordellistena ambusta Leconte.

FIG. 21. Mordellistena nunenmacheri Liljeblad.

Fig. 22. Mordellistena pustulata Melsheimer.

FIG. 23. Mordellistena convicta Leconte.

Fig. 24. Mordellistena discolor Melsheimer.

FIG. 25. Mordellistena bihamata Melsheimer.

Fig. 26. Mordellistena pubescens Fabricius.

FIG. 27. Mordellistena hebraica Leconte.

FIG. 28. Mordellistena liturata Melsheimer.

FIG. 29. Mordellistena pulchra Liljeblad, male.

FIG. 30. Mordellistena pulchra Liljeblad, female. 
VI. FIG. 1. Mordellistena fuscipennis Melsheimer.

Fig. 2. Mordellistena leporina Leconte.

FIG. 3. Mordellistena masoni Liljeblad.

FIG. 4. Mordellistena gigas Liljeblad.

FIG. 5. Mordellistena incommunis Liljeblad.

FIG. 6. Mordellistena attenuata Say.

FIG. 7. Mordellistena husseyi, new species.

FIG. 8. Mordellistena unicolor Leconte.

FIG. 9. Mordellistena aemula Leconte.

FIG. 10. Mordellistena aethiops Smith.

FIG. 11. Mordellistena vera Liljeblad.

FIG. 12. Mordellistena splendens Smith.

FIG. 13. Mordellistena divisa Leconte.

FIG. 14. Diclidia greeni Liljeblad.

FIG. 15. Diclidia obscura, new species.

FIG. 16. Diclidia laetula Leconte.

FIG. 17. Diclidia sexmaculata, new species.

FIG. 18. Diclidia propinqua Liljeblad.

FIG. 19. Sphingocephalus ovalis, new species.

VII. FIG. 1. Pentaria trifasciatus var. trifasciatus Melsheimer.

FIg. 2. Pentaria trifasciatus var. nubilus Leconte.

FIG. 3. Pentaria dispar Liljeblad.

FIg. 4. Naucles pusio Leconte.

FIG. 5. Naucles basalis Champion.

FIG. 6. Anaspis atrata Champion.

FIG. 7. Anaspis seposita, new species.

FIG. 8. Anaspis sericea Mannerheim.

FIG. 9. Anaspis flavipennis Haldeman.

FIG. 10. Anaspis militaris Smith.

FIG. 11. Anaspis duryi, new species.

FIG. 12. Anaspis beardsleyi, new species.

Fig. 13. Anaspis collaris Leconte.

Fig. 14. Anaspis rufa Say. 
. 


\section{MONOGRAPH OF THE FAMILY MORDELLIDAE (COLEOPTERA) OF NORTH AMERICA, NORTH OF MEXICO ${ }^{1}$}

\section{INTRODUCTION}

THIs monograph is the result of several years of interrupted study, which have been devoted to gathering material and the necessary literature, comparing and identifying specimens from almost every state, and making notes and drawings.

It is hoped that the examination of more than twenty thousand specimens from North America, including the old supposed types of Melsheimer and Leconte, in order to make the following account as complete as possible, will be of assistance to other workers in this field.

Since the publication in 1862 of Leconte's Synopsis of the Mordellidae of the United States, very little has been written that is of any help in the identification of specimens. Although several new species have been added by various authors, the system of arrangement made by Leconte has been changed but little.

At the beginning of this work the problem appeared to be very easy, but as more dependence had to be placed on the very brief descriptions given by previous writers (in some cases only a line or two), the identification and classification of these forms became increasingly more difficult. A great majority of the specimens sent for identification had been incorrectly identified by the collectors. Several times, especially at the beginning of the undertaking, I made similar errors, because of undescribed differences between the sexes. Sexual divergences were very rarely, if at all, mentioned in the older descriptions-a great mistake, since the males and females of several species, especially in the genus Mordellistena, differ considerably in color, ridges of the posterior legs, antennae, and maxillary palpi.

It was not long before I found it necessary to examine the available types of Melsheimer, Leconte, and Smith. This examination was somewhat unsatisfactory, since most of these so-called types were not designated, many were without dates, many did not agree with the original descriptions, and several could not be located. It has always been understood that the first specimen of each species in the Leconte collection, now in the Museum of Comparative Zoology, should be considered as the type, but I am doubtful of the value of this belief. In looking over some of Leconte's not very large series, it was evident that sometimes several species had been placed under one name. This might seem to indicate that Leconte himself was not sure of his species, but, in my opinion, this is not the case. Perhaps many differ-

1 The manuscript was completed in 1929. The only addition beyond that date was the substitution of the generic name Pentaria for Anthobates, see p. 196. 
ent persons have had access to the boxes in recent years, and it is impossible to be sure that no shifting of specimens has taken place in that time. A supposed type is of questionable value if it is without a label indicating either locality or type designation and if it is not at all in harmony with the original description.

At the present time the Mordellidae of North America, north of Mexico, include 193 species, distributed among fifteen genera. The first beetle of this family to be recognized from North America was described by Fabricius in 1775 , and fifteen authors have since contributed new species.

To the Mordellini belong a large number of small, usually wedge-shaped beetles, more or less arched, with the head bent downward and the abdomen usually prolonged into a more or less pointed process called a style. In the Anaspini the beetles are not arched, but are somewhat fusiform, the abdomen is not prolonged, and the sculpture is more or less transversely strigate.

These insects are usually covered with silky hairs, and many species are very prettily ornamented by having these hairs arranged in the form of lines, bands, and spots. The adults are found on dead or partly dead trees, but a great many frequent various flowers. The larvae live in dead trees or bore in the pith of plants; some are said to be carnivorous in habit and to feed upon lepidopterous and dipterous larvae.

The principal and most important characters used for separating the genera and species of Mordellini have been and are at present the ridges on the posterior tibiae and tarsi. These ridges are more or less carinated and are not formed merely by spinules or coarse pubescence, since denuded of this, a structural carina may be seen. These ridges differ in number, length, and direction and are transverse, oblique, or longitudinal.

Several species may have the same number of ridges. This is frequently the case in the genus Mordellistena. When this occurs, those species are grouped together, being then separated by other characters, such as color and the shape of the antennae or the maxillary palpi. J. B. Smith (1882: 73) said: "As a means of separating species this character is excellent, as a generic distinction its value is doubtful." I am fully convinced, however, that these ridges form a safer guide to generic distinction than does any other character mentioned. As a specific character in Mordellistena their value is a little doubtful, but, usually, they can be relied upon in finding the group to which the different species belong. Rudimentary ridges have been described by several writers on Mordellidae, but these ridges are not satisfactory characteristics. These writers mean by a rudimentary ridge a spinule or two of coarse pubescence, sometimes seen on one leg and not on the other, and it is of great importance to avoid including this in the count of the true ridges.

When identifying a specimen of Mordellistena the utmost care should be 
taken not to include the apical or subapical ridge, which also appears in the genus Mordella, nor to include the upper (sometimes faintly indicated) rudimentary ridge or ridges. On failure to succeed with the identification at the first attempt, a second trial should be made with the assumption of one more or one less ridge, especially if the ridges are not well indicated. The worker must be sure that the number is the same on both legs.

If these carinated ridges were to be omitted from consideration as generic characters, several changes would have to be made in the keys constructed by J. B. Smith (1882: 79). Tomoxia inclusa Leconte would then be the only true Tomoxia in North America, for it is the only species which agrees with the original description of the genus by Costa. The other three species, bidentata, lineella, and hilaris, do not possess the principal character of the genus: the last joint of the antennae should be "oblique truncate-emarginato."

Any one with specimens of the two species usually placed in the genus Glipodes, sericans and helva, can see without much trouble that there is very little to justify their being placed in the same genus. If the principal characters of the genus Mordella, as described by Linnaeus, should be followed, even as reviewed by Leconte or Smith, very few of the sixteen species included in it will be found to agree with the generic description, which says: "Hind tibiae and tarsi without ridges except the short subapical one of the former"'; Mordella borealis, fascifera, undulata, triloba, carinata, and discoidea all have a carinated ridge on the dorsal edge of the tibiae.

The length of the antennae as a whole, as well as the length of the individual segments, proves to be a rather constant character in the several species, and the shape of the last segment of the maxillary palpi is also a very good index to the species, especially among the entirely black forms.

By taking the ridges as the most prominent character in the group including Mordellistena aspersa and nigricans several species were merged as one. I have found, however, that it is impossible to use the ridges alone in the separation of these species, because, among certain specimens with the same number of ridges, some have the antennae reaching far beyond the base of the thorax whereas others have them reaching only to the middle of the thorax. In some the antennae are strictly filiform and in others they are more or less serrate; sometimes the fifth to tenth segments are each twice as long as broad, and in others they are short and nearly as broad as long; and the length of the third to fifth segments varies greatly. The shape of the terminal segment of the maxillary palpi is a very good character, but very few specimens are mounted so as to exhibit this part to good advantage, and it is necessary, in many smaller species, to dissect and mount it on the flat surface of the triangle, so as to get a correct outline of the segment, the angles of which vary considerably.

In nearly all the species the male characters were used for separation, 
and since rather large series were available for study it was possible to use males which had the genitalia extruded. I can say with full satisfaction that the many forms usually united with aspersa (as well as those included with nigricans) cannot be considered as the same species, even though they all possess the same number of ridges and are somewhat alike in coloration. A collector may find any of the above species, especially aspersa, from early spring to late fall, during the whole collecting season, but he will discover, after close examination, that the antennae and palpi of the specimens are not at all alike in shape and that they also vary greatly in size.

It is a very difficult undertaking to separate by their descriptions Mordellistena comata Leconte, picicornis Leconte, cervicalis Leconte, auricoma Helmuth, conformis Smith, texana Smith, exilis Liljeblad, insolita Liljeblad, marginalis Say, and singularis Smith. In my early work on Mordellidae I followed the path of previous workers and based the species almost entirely on the ridges, with no distinction between the real and the so-called rudimentary ones, but this method could not be continued with success. Of the above-mentioned species, comata, marginalis, and singularis alone appear to be recognizably distinct and valid. The others are synonyms of comata.

Mordellistena comata Leconte is a valid species from the West and South; cervicalis is based on a male and picicornis on a female of the same species; auricoma is a female, thereby being the same as picicornis; exilis is a male, equal to cervicalis. The type of texana has not been located, but several specimens from Texas have been examined and fully agree with the description. Aside from the entirely ferruginous head and thorax and one or two more ridges nothing has been found to separate texana from cervicalis; insolita is the same, with a slight difference in the ridges. $M$. conformis, texana, and insolita usually have the head and thorax without any markings or dark cloud, but I have seen specimens from the same locality with indications of a dark cloud. The type of conformis has the elytra with rather dense grayish pubescence, but this is not mentioned in the original description, and, aside from that, no differences have been found which would separate the latter species from cervicalis.

The genera in the subfamily Anaspini have been separated somewhat in harmony with the characters used by Leconte, with the exception of five genera which have been added to the North American fauna.

Diclidia and Anthobates are separated mainly by the characters of the antennal and tarsal segments, but nearly all the species can readily be recognized by the form of the genital appendages in the male.

All the species of the genus Anaspis bear abdominal appendages on the third or fourth segments. Other species similar in form and without abdominal appendages are separated by other characters, such as the length of the tarsal segments and epipleura. To these belong three genera, that are 
recorded from North America for the first time: Silaria, Larisia, and Nassipa.

Two more genera, Naucles and Sphingocephalus, consist of very small beetles of which one (Naucles pusio, formerly Anaspis) has been recorded heretofore from North America. These two genera may easily be separated by the labial palpi and by the strigation on the elytra.

The females of the Anaspini are very difficult to separate if collected alone, especially if uniform in color. They are, however, generally more robust in form than are the males.

The form of the mesosternum has been figured in many of the Mordellini, but in the descriptions I have not tried to describe the shape. It is difficult to recognize this structure unless the head and thorax are forced upward or dissected, and it is not a very important taxonomic character.

All the drawings have been outlined and shaded by me with the exception of sixteen which were shaded by Mr. O. Lunden, of Chicago, Illinois.

I wish to acknowledge the generous gifts and loans of material as well as other favors of value for completion of this monograph, from the following institutions, private collectors, and friends: J. M. Aldrich, E. A. Schwarz, E. A. Chapin, H. S. Barber, and W. S. Fisher, of the United States National Museum; L. L. Buchanan, of the United States Department of Agriculture; Henry Skinner and E. T. Cresson, of the Academy of Natural Sciences of Philadelphia; P. Engelhard and Charles Schaeffer, of the Brooklyn Institute of Arts and Sciences ; Andrew J. Mutchler, of the American Museum of Natural History; Hugo Kahl, of the Carnegie Museum; W. J. Gerhard, A. B. Wolcott, and J. T. Zimmer, of the Chicago (Field) Natural History Museum; Charles W. Johnson, of the Boston Society of Natural History; Nathan Banks, of the Museum of Comparative Zoology; J. C. Bradley, of Cornell University ; F. M. Gaige, C. L. Hubbs, and Melville H. Hatch, of the University of Michigan; John J. Davis, of Purdue University; Theodore H. Frison, of the University of Illinois; James S. Hine, of Ohio State University ; H. B. Hungerford, of the University of Kansas ; G. F. Ferris, of Leland Stanford University ; J. N. Knull, of the Pennsylvania Department of Agriculture; Norman Criddle and Ralph Hopping, of the Department of Agriculture, Canada ; Kenneth F. Auden, of the University of British Columbia; G. A. Akerlind; W. S. Blatchley; J. F. Brimley; Maurice Bristol; A. B. Champlain; K. F. Chamberlain; Charles Dury; P. J. Darlington; Henry Dietrich ; C. A. Frost ; H. C. Fall ; J. W. Green ; R. F. Hussey ; T. N. Hubbell; V. Harnach; W. Knaus; H. P. Loding; Miss Edith W. Mank; L. L. Muchmore; Frank R. Mason ; F. W. Nunenmacher ; Frank J. Psota ; O. Park ; Wirt Robinson; H. Ramstadt; Dayton Stoner; C. Sellinger; F. J. W. Schmidt; H. F. Wickham; and A. K. Wyatt.

The names of institutions are abbreviated hereinafter as follows : A.M.N.H. 
(American Museum of Natural History), C.U. (Cornell University), I.S.N.H.S. (Illinois State Natural History Survey), I.U. (University of Illinois), K.U. (Kansas University), U.M. (University of Michigan), P.U. (Purdue University), St.U. (Leland Stanford University), U.S.N.M. (United States National Museum).

\section{THE MORDELLIDAE}

\section{KEY TO SUBFAMILIES OF MORDELLIDAE}

Abdomen with last dorsal segment prolonged, conical; claws cleft and pectinate; posterior femora large

(p. 14) MORDELLINI

Abdomen without anal prolongation; claws not cleft; posterior femora moderate (p. 187) ANASPINI

\section{KEY TO GENERA OF MORDELLINI}

Posterior tibiae without subapical ridge on outer face

Posterior tibiae with subapical ridge on outer face

2. Posterior tibiae with a carinated ridge along outer dorsal edge and furnished with a long oblique ridge on outer face, the two united near outer apical angle of tibiae; first segment of posterior tarsi also with a similar oblique ridge.

(p. 14) Glipodes

Posterior tibiae with a narrowed carinated ridge along outer dorsal edge and furnished with a long oblique ridge on outer face, the two united near outer apical angle of tibiae, as in Glipodes; first segment of posterior tarsi with two short, very oblique ridges, as in Mordellistena (p. 16) Conalia

Posterior tibiae with a long oblique carinated ridge from outer apical angle of tibiae; first and second segments of posterior tarsi also with similar ridge.

(p. 18) Isotrilophus

3. Eyes not reaching occiput, head somewhat extended behind eyes (p. 20) Glipa

Eyes reaching occiput

4. Antennae more or less clavate, or strongly serrate; scutellum triangular; legs without carinated ridges, except the short subapical one (p. 30) Mordella

Posterior tibiae with a carinated ridge along outer dorsal edge; first segment of posterior tarsi with a similar ridge less strongly indicated ............... (p. 54) Tomoxia

Posterior tibiae with one to six short, more or less oblique, ridges on outer face; first, second, and third segments of posterior tarsi with similar ridges, although the number differs in different species (p. 68) Mordellistena

\section{GLIPODES LECONTE}

Glipodes Leconte, 1862, p. 47. Emery, 1876, p. 79. Smith, 1882, pp. 74, 84. Champion, 1891, p. 305. Blatchley, 1910, pp. 1309, 1315.

DESCRIPTION.-The species of this genus are large, cuneiform, brownish, and covered with dense, sericeous, yellowish brown pubescence; scutellum small, rounded, triangular; anal style moderately long; posterior tibiae without subapical ridge, but carinated along outer dorsal edge and furnished with a long oblique ridge on outer surface, reaching half the length of the tibiae, the two connected near outer apical angle of tibiae; first segment of 
posterior tarsi bearing similar, but somewhat shorter, carinated dorsal ridges; second and third segments of posterior tarsi each with a short oblique ridge extending a little upward from outer apical angle, the latter very much prolonged; eyes very large, pointed on basal outer angle, rather coarsely granulated, and hairy; antennae feebly serrate; last segment of maxillary palpi broad, more securiform than scalene triangular, and, in male, with an external, articulated, bifurcated appendage at base, branches of which are nearly as long as segment; no vestige of this visible in female; last segment of labial palpi triangular, broadly emarginate at tip.

REMARKS.-This genus differs from Conalia principally in the carinated ridges on the posterior first tarsal segment, these consisting of a carinated ridge along the outer edge and an oblique ridge running inward, whereas in Conalia the first segment of the posterior tarsi has two short, slightly oblique ridges at about the middle, of the same type as in Mordellistena (Pl. I, Fig. 1a).

Formerly, two species of this genus were recorded from North America, G. sericans Melsheimer and G. helva Leconte, but as the latter species agrees exactly with the genus Conalia in the ridges of the posterior tibiae and tarsi and differs in other respects from sericans I retain only sericans in the genus Glipodes.

\section{Glipodes sericans (Melsheimer)}

$$
\text { (PI. I, Fig. 2) }
$$

Mordella sericans Melsheimer, 1846, p. 312, Pennsylvania.

Glipodes sericans Leconte, 1862, p. 48. J. B. Smith, 1882, p. 84. Blatchley, 1910, p. 1315.

DESCRIPTION.-Cuneiform; upper surface entirely reddish brown or dark rufous with sericeous, yellowish brown pubescence; antennae reddish brown; palpi flavo-testaceous; underside more rufous; anterior femora flavo-testaceous, rest of legs fuscous.

Head somewhat large, one-fourth narrower than elytra at base and onethird broader than long, densely and coarsely punctured; eyes unusually large, covering two-thirds of head, broadly rounded in front and acutely pointed at basal outer angle, reaching occiput, covered with fine stiff hairs, which are denser and longer at front and sides, and coarsely granulated; antennae filiform with two stout basal segments; second segment one-half length of first; third and fourth segments narrow, slightly broader at apex, fourth one-fifth longer than third; fifth longest, one-third longer than fourth; sixth to tenth elongate, narrow, each diminishing in width to tenth segment and each about one-fourth longer than fourth; eleventh longer than tenth, sides parallel; last segment of maxillary palpi securiform in male and with an external, articulated, bifurcated appendage extending outward from base, the branches of which are nearly as long as the segment; no trace of this in female; undersurface of palpi with a dense brush of hairs. 
Pronotum a little broader than elytra at base, one-third broader than long; when viewed from above the sides appear evenly rounded to apex; when viewed from side they are nearly straight two-thirds of distance from base ; apical and basal angles obtuse ; surface moderately punctured; base at middle, in front of scutellum, somewhat narrow, rounded; scutellum small, triangular.

Elytra four times as long as thorax, sides very slightly curved inward, apex rounded, surface reticulate and finely punctured; anal style comparatively short, twice as long as last abdominal segment, bluntly pointed and black at tip; posterior tibiae without subapical ridge, but carinated along outer dorsal edge and furnished with a long oblique ridge on outer surface, reaching half way or more basad, the two ridges being connected near outer apical angle of tibiae; first segment of posterior tarsi bears similar somewhat shorter carinated dorsal ridges; second and third segments of posterior tarsi each with a short oblique ridge beginning at outer apical angle, following segments very much prolonged.

Length: to apices of elytra, 7-8 $\mathrm{mm}$.; to tip of anal style, 9-10 mm.

REMARKS.-This large and interesting species is readily recognized by the uniform reddish brown color, by the carinated ridges on the posterior tibiae and first tarsal segments, and by the structure of the male maxillary palpi. It seems to be exceedingly rare, since only a few specimens have been received for identification. Charles Dury has collected this species on the foliage of ash. Through the courtesy of Nathan Banks, I have seen Melsheimer's type in the Museum of Comparative Zoology. This type is a female, without posterior tarsi, but in Leconte's collection there are two specimens, a male and a female. One of these, in perfect condition, agrees with the above description. The figure given by J. B. Smith in his Synopsis of the Mordellidae of the United States (1882, Pl. 2, Fig. 10) is not correctly drawn.

Previous RECORDS.-Pennsylvania (Melsheimer); central, southern, and western states (Leconte); central and southern states (Smith); Cincinnati, Ohio (Dury); Posey County, Indiana (Blatchley); Great Falls, Virginia (Banks).

Material examined.-Kansas: no locality (P.U., Ashburn coll.).

\section{CONALIA MULSANT AND REY}

Conalia Mulsant and Rey, 1858, p. 313.

The chief characters given by Mulsant and Rey for this genus are as follows: "Tibias postérieurs sans dent sur leur arête dorsale; rays sur leur face externe d'une hachure ou d'une ligne, naissant de leur angle postéroexterne et longitudinalement avancée au moins jusqu'a la moitié de la longueur des dits tibias, en s'écartant graduellement un peu du bord ex- 
terne." This description was taken from a mutilated specimen without hind tarsi, from Hungary, and the insect was named Conalia baudii. Schilsky (1895: 29) gave a more complete description of this insect and added that the first segment of the hind tarsi bears also two short, slightly oblique ridges, and that the second and third segments are without ridges (Pl. I, Fig. 1 $b$ ).

I have two specimens of this insect from Moravia, and they agree with the above description so far as the tibiae and the first segment of the tarsi are concerned, but in addition they show plainly a fine carinated ridge along the outer dorsal edge of these segments, as in Glipodes, although less strongly indicated. This ridge seems to have been entirely overlooked by previous writers. One of the North American species formerly placed in Glipodes agrees exactly with the European Conalia baudii in respect to these ridges, and, therefore, I propose to add this genus with the following species to the North American Mordellini.

\section{Conalia helva (Leconte)}

(Pl. I, Fig. 3)

Glipodes helva Leconte, 1862, p. 48, Georgia. Smith, 1882, p. 84 .

DESCRIPTION.-Cuneiform, upper surface and undersurface entirely fuscous, in some specimens light reddish brown (except eyes and ridges, which are black), densely covered with sericeous, yellowish brown pubescence.

Head large, nearly as broad as elytra at base, minutely punctured and with surface very finely aciculate; eyes moderate in size, coarsely granulated, covered with fine hairs; antennae filiform or very slightly serrate, reaching to about base of thorax; third segment very little longer than fourth; fifth one-fourth longer than fourth; sixth to tenth equal in length, each a little shorter than fifth; eleventh one-third longer than tenth; last segment of maxillary palpi somewhat cultriform, or nearly the shape of an isosceles triangle.

Pronotum a little broader than elytra at base, about one-fifth broader than long, evenly rounded to apex; basal angles obtuse; basal lobe in front of scutellum broadly rounded; surface finely punctured; scutellum very small, triangular.

Elytra with surface reticulate, more strongly punctured, tip gradually rounded from the sides; middle legs with tibiae longer than all tarsal segments combined; posterior tibiae with a carinated ridge along outer dorsal edge and a long, oblique, carinated ridge, reaching two-thirds the length of tibiae, connected with outer dorsal ridge near outer apical angle; first segment of posterior tarsi with two short, oblique ridges on outer face; anal style rather narrow, pointed, more than twice as long as last abdominal segment. 
Length : to apices of elytra, 3.5-4.25 mm.; to tip of anal style, $4.5-6 \mathrm{~mm}$.

REMARKS.-This species was described by Leconte as Glipodes, but I cannot associate it with that genus because of the great difference in ridges, palpi, antennae, eyes, and other characters. It agrees exactly with Conalia, which was founded on Conalia baudii from Hungary, as mentioned in the generic notes. It is rare in collections. It varies but little in color, although specimens from Florida are more finely pubescent than are those from other localities. The type of this species, now in the Museum of Comparative Zoology, has been examined by me; it agrees with the above description. The species appears from June 6 to August 7.

Previous records.-Georgia (Leconte).

Material examined.-Florida: Paradise Key (Knull).

Georgia: Spring Creek, Decatur County (C.U.).

Indiana : Miller (Liljeblad).

Kansas : Rock County (Knaus) and Douglas County (Tucker, K.U.).

Louisiana: New Orleans, June 13 (Soltau, U.S.N.M.).

Massachusetts : Framingham (Frost).

\section{ISOTRILOPHUS, NEW GENUS}

Description.- Small, cuneiform beetles, having the pygidium or anal style very short, scarcely visible beyond the tip of the elytra; antennae short, with segments five to eleven broader, forming an elongated club; last segment of the maxillary palpi subcultriform; eyes not reaching the occiput; scutellum very small, triangular; posterior tibiae without subapical ridge, but furnished with a long, oblique, carinated ridge on the outer face, from the outer apical angle of the segment to near the middle and reaching to about one-third of the distance from base; the first and second segments of the posterior tarsi each bear a similar carinated ridge (Pl. I, Fig. 1c).

GENOTYPE.-I. erratica (Smith) is the only species recorded from North America.

Remarks.-This genus differs from Glipodes principally in size, in having no carinated ridge on the outer edge of the posterior tibiae, in having the first and second segments of the posterior tarsi with a ridge similar to that on the tibiae, and in having the anal style very short. It differs from the genus Conalia in the number of ridges on the first segment of the posterior tarsi; in Conalia the first segment bears two short, very oblique ridges, and there is no ridge on the second segment.

\section{Isotrilophus erratica (Smith) \\ (Pl. I, Fig. 4)}

Mordellistena erratica Smith, 1883, p. 80, Florida.

Conalia ebenina Champion, 1891, p. 306; 1896, p. 49. 
DESCRIPTION.--Short, cuneiform, entirely black or brownish black, covered with reddish brown pubescence.

Head rather large, very minutely punctured; eyes moderately large, not quite reaching occiput, not hairy, finely granulated; antennae short, nearly reaching base of thorax; segments one to four narrow ; fifth to eleventh about as broad as long; third and fourth subequal in length ; fifth triangular, onethird longer than fourth and much broader at apex; sixth to tenth subequal in length, as broad as long, each a little shorter than fifth; last segment of maxillary palpi rather stout, subcultriform, with inner angle one-half length of apical.

Pronotum about one-fifth broader than long, very little broader than elytra at base, surface minutely aciculate and finely punctured, basal angle obtuse, basal lobe broadly rounded at middle in front of scutellum; scutellum small, scarcely visible, triangular.

Elytra two and one-half times as long as pronotum, sides gradually tapering to apex, the apices rather broadly rounded, surface with fine raised punctures. Posterior tibiae without subapical ridge, but with a long carinated ridge on outer surface, running obliquely from outer apical angle upward to near middle at one-third distance from base, this ridge very strongly indicated ; first and second segments of posterior tarsi each bear a similar oblique ridge.

Length : $2 \mathrm{~mm}$.

REMARKs.-The type of Mordellistena erratica Smith, not fully described, has been examined by me; it is the same as Conalia ebenina Champion. It is difficult to say why Smith overlooked certain characters. He stated in his notes: "This species is curious and interesting by the structure of the posterior tibiae and tarsi; the subapical ridge of the tibiae is indistinct and the outer ridge very strongly marked, is very like that on the posterior tibiae of Glipodes." The type does not have any subapical ridge. The dorsal ridge starts from the very tip of the tibiae, and this alone should have been enough to keep erratica out of the genus Mordellistena. No ridge on the second segment of the posterior tarsi is mentioned in Smith's description, although a similar ridge, as on the first segment, is present on the type.

The type of Conalia ebenina Champion has not been examined by me, but the description, as well as the figure given by Champion, proves without doubt that he was in error in placing his species in the genus Conalia. This error was probably caused by the incomplete description given by Mulsant and Rey, whose type specimen of Conalia baudii was without posterior tarsi. It may also have been due to the carelessness of Smith in not fully describing his erratica and to his mistake in placing it in the wrong genus.

Nine specimens of this interesting species have been collected by Charles Dury at Brownsville, Texas, and from these specimens, as well as from the type of erratica, the present notations have been made. 
These specimens agree with Champion's description of Conalia ebenina, but I cannot place them in that genus while in possession of two specimens of Conalia baudii Mulsant and Rey, a species which has the posterior tibiae with a long oblique ridge, the first segment of the posterior tarsi with two short oblique ridges, and the second and third segments without ridges.

$C$. ebenina has a long oblique ridge on the posterior tibiae and a similar ridge on the first and second segments of the posterior tarsi, exactly like the type of Mordellisterna erratica Smith. These differences of the ridges are sufficient to withdraw ebenina from the genus Conalia, just as clearly as Glipodes is separated from Conalia. Because of the above facts, I propose a new genus, Isotrilophus, for M. erratica Smith, this species having eight years priority over ebenina Champion.

Previous RECORD.-Florida (Smith).

Material examined.-Texas : Brownsville (Dury).

\section{GLIPA LECONTE}

Glipa Leconte, 1859, p. 17; 1862, p. 46. J. B. Smith, 1882, p. 79. Champion, 1891, p. 236.

DESCRIPTION.-Cuneiform; eyes finely granulated, not reaching occiput (head more or less angularly extended behind the eyes); anal style generally stout; middle tibiae unusually long, a little longer than all tarsal segments combined on same pair of legs; posterior tibiae and tarsi without ridges, except the short subapical one; antennae more or less serrate; last segment of maxillary palpi variable (Pl. I, Fig. 1d).

REMARKs.-This genus was erected by Leconte (1859: 17) and based upon Mordella hilaris Say (1835: 190), with its characters given as follows: "Palpi maxillares articulo ultimo valde dilatate securiforme." Leconte, in his Synopsis of the Mordellidae of the United States (1862: 46), gave a more complete description as follows:

Cuneiform; the scutellum is rounded triangular, the anal style is short, and subemarginate; the hind tibiae and tarsi are without ridges, except the short, subapical one of the former; the eyes are very finely granulated, the antennae tolerably strongly serrate, and the last segment of the maxillary palpi very broadly securiform and moderately thick, with the extremity hollowed out.

J. B. Smith, in his Synopsis of the Mordellidae of the United States (1882: 79), placed Mordella hilaris Say in the genus Tomoxia, with the following remarks :

Mordella hilaris Say, for which Dr. LeConte described the genus Glipa, belongs I believe to this genus (Tomoxia). Glipa was based on the broadly securiform maxillary palpi and the non-emarginate scutellum; but $T$. lineella has the palpi nearly as broad, and the latter characteristic is so minute, and the emargination in Tomoxia (sensu LeConte) is so small that I cannot persuade myself to consider it as distinct. 
Champion (1891: 236) stated that Mordella hilaris Say also inhabits Central America, and said that Smith overlooked several characters. He noted especially that the eyes do not reach the occiput on this insect, and, therefore, he held the genus Glipa valid.

The above characters given by Leconte differ so slightly from those of other genera of Mordellini that Smith undoubtedly was justified in considering Glipa invalid, but Leconte, as well as Smith, entirely overlooked at least one character that differs completely from characters of either Tomoxia or Mordella - the eyes do not reach the occiput or rather the head is more or less angularly extended behind the eyes in Glipa hilaris. It is true that Mordella oculata Say, $M$. inflammata Leconte, $M$. octopunctata Fabricius, and $M$. perlineata Fall have the same character and for this reason should not have been placed in the genus Mordella, since the generic type, Mordella aculeata Linnaeus, has the eyes reaching the occiput. The same holds true in Tomoxia bidentata (Say), but not in the type species, Tomoxia biguttata Gyllenhal (nec bucephala Costa).

In view of these considerations I have retained the genus Glipa and propose also to merge Tomoxia bidentata, Mordella oculata, $M$. inflammata, $M$. octopunctata, and $M$. perlineata with this genus to which the preceding generic characters may be ascribed.

\section{KEY TO SPECIES}

Eyes hairy 2

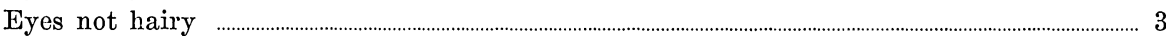

2. Last segment of maxillary palpi very broadly securiform; elytra with an irregular grayish band from base to near middle and an oblique band one-fourth from apex ; size large, 10-12 mm.; Pl. I, Fig. 5

(p 22) hilaris

Last segment of maxillary palpi less elongate securiform; elytra black, with large basal band including a black spot, and an angulated, cinereous spot behind middle; size smaller, 7-8 mm.; Pl. I, Fig. 6 (p. 23) oculata

Last segment of maxillary palpi scalene; elytra black, with a curved basal spot extending downward from near scutellum and a narrow oblique band from humerus, a more or less oblong spot at middle, and a reniform spot one-fourth from tip, with yellow or sometimes silvery pubescence; Pl. I, Fig. 7

(p. 25) octopunctata

3. Last segment of maxillary palpi elongate, somewhat securiform; elytra brownish with variegated cinereous spots or lines, with a long lunate spot extending from base downward to near scutellum, and a spot at middle near base more or less rhomboidal; Pl. I, Fig. 8 (p. 26) bidentata

Last segment of the maxillary palpi an isosceles triangle, or somewhat cultriform; elytra black with a large spot at base surrounding scutellum and reaching sides, orange colored, somewhat golden, leaving a triangular black spot near humeral angle and a lunate spot of bright orange one-fourth from apex; Pl. II, Fig. 1

(p. 28) inflammata

Last segment of maxillary palpi broadly triangular, nearly securiform; elytra black, with suture and four narrow stripes cinereous; Pl. II, Fig. 2 ........ (p. 29) perlineata 


\section{Glipa hilaris (Say)}

(Pl. I, Fig. 5)

Mordella hilaris Say, 1835, p. 190, Pennsylvania; Leconte ed., 1859, p. 661.

Glipa hilaris Leconte, 1859, p. 17 ; 1862, p. 46. Champion, 1891, p. 236, Pl. XI, Fig. 12. Glipa hieroglyphica Schwarz, 1878, p. 372.

Tomoxia hilaris Smith, 1882, pp. 79, 80, Pl. I, Figs. 30, 32. Blatchley, 1910, p. 1311.

Description.-Cuneiform; head black, with violaceous reflection in certain lights; maxillary palpi with basal segment testaceous in male, fuscous in female, apical segments in both sexes more or less fuscous; antennae black, basal segments a little paler in male; thorax black, with sparse grayish pubescence, leaving an irregular quadrate spot on each side of middle; scutellum with dense grayish or silvery pubescence; elytra black, with an irregularly grayish pubescent band from base to near middle, of the following form: a band from base near scutellum downward to a little below, then obliquely upward to near humeral angle; from middle of this band is a double band downward to about one-third from base, surrounding an obovate spot, the two elements of this band confluent in some specimens, forming a grayish spot, then obliquely outward to near middle of elytra, then again obliquely upward a short distance, and then abruptly outward to margin; a short grayish pubescent spot at side below humeral angle; a narrow sutural line from base to one-third from apex, where it is connected with an irregular oblique band, which extends downward to near margin onefourth from tip; upper lateral area above basal band black, area below this band has sericeous yellowish brown pubescence; underside black, with more or less violaceous luster, partly covered with fine grayish pubescence; legs black, except anterior femora in male, which are testaceous; tibial spurs reddish brown.

Head large, densely and rather deeply punctured; eyes large, obovate, very finely granulated, hairy; last segment of maxillary palpi broadly securiform; antennae short, reaching middle of thorax, with second segment one-fourth shorter than third; third segment one-third longer than second and one-half narrower at base, slightly decreasing in width to apex; fourth very little longer than third, but nearly twice as broad at apex; fifth to tenth equal in length, about as broad as long, or strongly serrate; eleventh a little longer than tenth, broadest at middle and rounded at apex.

Pronotum one-third broader than long, broadest at middle, sides slightly rounded, basal and apical angles slightly obtuse or subacute; basal lobe broadly rounded in front of scutellum; scutellum rounded triangular.

Elytra narrower at base than thorax, with an oblique costa from humerus to near middle, broadest at base, slightly acuminate to near apex, which is rounded, densely punctured and scabrose; underside finely punctured ; posterior tibiae with a short subapical ridge near tip, middle tibiae longer than 
all tarsal segments of same pair of legs; last abdominal segment at middle excavated or furrowed in male, not so in female; anal style short, carinated above, rather broad at tip and very slightly bilobed; anterior femora and tibiae more curved in male, and femora with setae on inner side.

Length: to apices of elytra, 8.5-9 mm.; to tip of anal style, 10.5-11 mm. REMARKS.-This is one of the largest species of Mordellini and is therefore comparatively easy to recognize. It varies a little in the color and markings, but the general pattern is constant. Schwarz's hieroglyphica was, no doubt, the male of this species, for he mentioned the excavated fifth ventral segment. It seems to be rather rare and has been taken on the flowers of Hydrangea cordata. Its movement is said to be very rapid.

Previous RECords.-Pennsylvania (Say); middle and western states (Leconte); southwestern Pennsylvania (Hamilton); Cincinnati, Ohio (Dury) ; Posey County, Indiana ? (Blatchley).

Material examined.-Illinois: Havana, June 14 and Parker, June 4 (Hart, I.U.) and Grant Tower, June 29 (I.S.N.H.S.).

Kansas: Chautauqua County (Beamer); Douglas County (Williams); Onaga (Knaus); no locality (Ashburn coll., P.U.).

Missouri: Atherton, July 16 (Adams, K.U.).

Texas : Lexington, June (Birkmann, I.U.).

\section{Glipa oculata (Say)}

(Pl. I, Fig. 6)

Mordella oculata Say, 1835, p. 190, Pennsylvania and Indiana; Leconte ed., 1859, p. 661. Leconte, 1862, p. 47. Smith, 1882, pp. 81, 83. Blatchley, 1910, pp. 1312, 1314. Mordella jovialis Leconte, 1878, p. 428.

DESCRIPTION.-Cuneiform; black or sometimes more reddish brown; head black with cinereous pubescence; antennae dull rufous, dusky toward tip; maxillary palpi with basal segments dull rufous, apical segments darker; thorax black, with base, margin, and a band each side of middle with cinereous pubescence, in some specimens only faintly indicated; scutellum with cinereous pubescence; elytra black or sometimes reddish brown, with a large, round basal band, extending posteriorly on each elytron to a point near middle, with cinereous pubescence, including a black spot in center and an angulated cinereous band behind middle, which reaches suture and lateral margin in some specimens cinereous, suture very narrowly cinereous except in well-marked specimens; anal style black, with cinereous pubescence at base; underside black with more or less cinereous pubescence at sides and on abdominal segments, which also are a little rufous at apex; anterior legs, as well as tibiae and tarsi on middle, and posterior legs more or less rufous.

Head rather densely and finely punctured; antennae long, a little longer than head and thorax, fifth to tenth segments serrate; fourth segment one- 
fourth longer than third; fifth about equal in length to fourth, but much broader at apex; sixth to tenth subequal in length, each diminishing in width to tenth; eleventh oval; last segment of maxillary palpi securiform, in female somewhat longer, or more scalene; eyes not quite reaching occiput, finely granulated and hairy.

Pronotum broader than long, densely and finely punctured, evenly rounded to apex but nearly straight when viewed from side; basal angles subacute, apical angles rounded; base in front of scutellum broadly rounded; scutellum triangular, rounded at apex.

Elytra twice as long as broad, surface reticulate and with deep punctures, apex rounded, with no distinct margin; underside somewhat densely and coarsely punctured; anterior tarsi with second to fourth segments dilated; middle tibiae a little longer than all tarsal segments of same pair of legs; posterior tibiae with subapical ridge near tip ; anal style long, blunt at tip; male separated from female by the more securiform maxillary palpi, also by the anterior femora and tibiae, which in male have long setae on inner side.

Length : to apices of elytra, 5-6 mm.; to tip of anal style, 7-8.5 mm.

REMARKs.- This species is rather rare. It is said to have been taken on Ambrosia and to appear from May to October. It is readily identified by the large, basal, cinereous-pubescent area, which usually surrounds a black spot, and the cinereous spot a little below the middle. These bands and spots vary considerably, especially the basal band, which in some specimens is broken, more like a lunule, and sometimes has a broken line from humerus to middle. The middle band sometimes does not reach either suture or margin. Mordella jovialis Leconte is, no doubt, only a well-marked variation of this species ; I have not found two examples that are exactly alike in their markings. Two specimens from Pennsylvania and Michigan have the marking's with yellowish or golden pubescence.

Previous RECords.-Pennsylvania and Indiana (Say); middle, southern, and western states (Leconte); Bosque County, Texas (Belfrage); southwestern Pennsylvania (Hamilton); Cincinnati, Ohio (Dury); Ames, Iowa (Osborn) ; Iowa City, Iowa (Wickham); Riverton, Iowa (Shimek); and Indiana, southern half of state (Blatchley).

Material examined.-Georgia: Spring Creek (Bradley).

Illinois: Eggers (Wolcott); Chicago (Liljeblad); Muncie, Normal, Urbana, and Karnak (I.U.).

Indiana: East Gary (Liljeblad).

Kansas: Onega (Warren) ; Salina (Knaus); Douglas County (Alexander, K.U.) ; Labette County (Beamer, K.U.) ; no locality (Ashburn coll., P.U.).

Maryland: Plummers Island, July 9 (Fisher, U.S.N.M.). 
Michigan: Washtenaw County (Hubbell and Hatch); Pigeon, Huron County (Hussey); Paw Paw Lake (Liljeblad).

Missouri: Atherton (Adams, K.U.).

Ohio : Cincinnati (Soltau, U.S.N.M.).

Pennsylvania: Waynesburg (Gayton); Jeannette (Knull).

\section{Glipa octopunctata (Fabricius)}

(Pl. I, Fig. 7)

Mordella octopunctata Fabricius, 1775, p. 263. Leconte, 1862, p. 46. Smith, 1882, pp. 81, 82. Blatchley, 1910, p. 1313.

DESCRIPTION.-Cuneiform; black with yellowish markings; head black, covered with cinereous pubescence; antennae with segments five to eleven black, basal segments dark testaceous; maxillary palpi black; thorax black, with base, sides, and apical margin cinereous, a reticulated or scalloped band on apical third, two pointed projections extending upward each side of middle and two downward from scalloped band; scutellum black; elytra black, with a curved basal band surrounding scutellum and prolonged downward at middle to about one-fourth of elytra; a narrow oblique marginal band from humerus downward one-third of elytra, a small, half-rounded subsutural spot at middle, and a reniform spot at middle one-fourth from tip with yellowish pubescence, in some specimens more or less silvery ; underside black with cinereous pubescence, denser at sides and base of abdominal segments; legs black; anal style black with cinereous pubescence at base.

Head large, densely and finely punctured; antennae short, reaching to about middle of thorax, segments five to eleven serrate; fourth segment onefourth shorter than third; fifth to tenth each about as long as fourth, serrate; eleventh a little longer than tenth, curved outward on inner side; last segment of maxillary palpi scalene triangular or nearly an isosceles triangle; eyes not reaching occiput, finely granulated, not hairy.

Pronotum one-fourth broader than long, broader than elytra at base; evenly rounded to apex when viewed from above; viewed from side, nearly straight; basal angles subacute; apical angles rounded; basal lobe in front of scutellum broadly rounded; surface reticulate, finely punctured; scutellum trapezoidal, broadly rounded at apex.

Elytra two and one-half times longer than broad, surface reticulate, finely punctured; apices widely separated, pointed, and finely margined; anterior tarsi with second to fourth segments dilated; middle tibiae as long as all tarsal segments of same pair of legs, posterior tibiae with a short, subapical ridge near tip ; anal style long and slender ; male with anterior femora and tibiae more curved and set with long setae.

Length: to apices of elytra, 6-7 mm.; to tip of anal style, 8-9 mm.

REMARKS.-This species is rather common on flowers of many species 
from June to August. The markings do not differ very much, but the pubescence is either gray, silvery, or yellowish.

Previous Records.-North America (Fabricius); central and southern states (Leconte); southern Virginia (Horn); southwestern Pennsylvania (Hamilton); Cincinnati, Ohio (Dury); Ames, Iowa (Osborn); Iowa City, Iowa (Wickham); Cedar Rapids, Iowa (Brendel); Indiana, southern half of state (Blatchley); Plano, Texas (Tucker); New York state (Nicolay).

Material examined.-Illinois: Havana, Galena, Freeport, Mahomet, Anna, Aldridge, Savanna, Metropolis, Fox Lake, Algonquin, and Carbondale (I.U.) ; and Du Bois, Pulaski, and Murphysboro (I.S.N.H.S.).

Indiana: Mineral Springs, Miller, and East Gary (Gerhard, Wolcott, and Liljeblad).

Kansas: Haskell and Cowley County (K.U.); no locality ( $\Lambda$ shburn coll., P.U.).

Kentucky: Wickliffe (I.U.).

Maryland : Beltsville (I.U.).

Michigan: Muskegon (Wolcott) ; Washtenaw County (Hubbell, U.M.) ; Pentwater, Whitehall, and Paw Paw Lake (Liljeblad).

Minnesota: St. Anthony Park (I.U.).

Missouri : St. Louis (Liljeblad).

New Jersey: Phillipsburg (J. W. Green), Ridgewood (Leonard coll., C.U.).

New York: Rochester Junction (Leonard coll., C.U.); Ithaca (Anderson) ; Farmingdale (Morrow coll.).

North Carolina: Southern Pines (Manee); Asheville (Harnach).

Ohio: Columbus (Liljeblad).

Pennsylvania: Philadelphia (C.U.); Montgomery County (Crew coll., C.U.).

Tennessee: Knoxville (Hill); Chattanooga (Hubbell).

Texas : Lexington (Birkmann, I.U.).

Virginia: Quantico (Duncan); Falls Church (Hubbell) ; Nelson County (Robinson).

Wisconsin : Kilbourn (Liljeblad).

\section{Glipa bidentata (Say)}

(Pl. I, Fig. 8)

Mordella bidentata Say, 1823, p. 277, Missouri; 1859, p. 164.

Tomoxia bidentata Leconte, 1862, p. 45. Linell, 1887, p. 171 . Smith, 1882, p. 79.

Blatchley, 1910, p. 1311. Frost, 1913, p. 126.

DesCRIPTION.-Cuneiform, much narrower in male than in female, covered with long, cinereous pubescence, denser near eyes; antennae and palpi rufo-testaceous; thorax dusky, a little browner at base, with cinereous 
pubescence in spots and lines; a broad line on each side of middle, from base upward to middle; two spots on each side of this, nearer margin, apex, and sides; scutellum with cinereous pubescence; elytra brownish, with variegated cinereous spots and lines as follows: a long lunate mark from base near scutellum extending downward one-fourth, a spot at middle near base, a double line extending downward from near base with the two elements connected a little below middle, a sutural streak one-fourth from base, running: downward to a little below central double line and curving outward to near margin, a curved apical band reaching suture and margin, and a spot each side near middle (these bands and spots are sometimes confluent and therefore difficult to describe); anal style with cinereous pubescence near basal underside black or dark reddish brown, rather densely covered with cinereous pubescence; leg's with femora black, tibiae and tarsi more reddish.

Head comparatively large, somewhat coarsely punctured; antennae with fifth to tenth segments serrate; fourth segment one-third longer than third; fifth segment about equal in length to fourth, triangular, much broader at apex; sixth to tenth equal in length, each a little shorter than fifth; eleventh large, rounded on inner side; last segment of maxillary palpi elongate, more securiform than scalene triangular; eyes large, finely granulated, not hairy, and not reaching occiput (head extended behind eyes).

Pronotum one-third broader than long, broader than elytra at base, evenly rounded to apex; basal angle acute, apical obtuse; basal lobe broadly rounded at middle, in front of scutellum; surface roughly sculptured and with fine punctures; scutellum strongly emarginate, apical angles pointed.

Elytra twice as long as broad, slightly narrowed to apex, which is obliquely truncate, without distinct margin and with sutural angle prolonged in a short spine; surface sculptured in wavy lines like ridges, punctures fine; underside finely punctured; anterior tarsi with third and fourth segments dilated, middle tibiae about as long as all tarsal segments of same pair of legs; posterior tibiae with subapical ridge near tip; anal style short, blunt at tip.

Length: to apices of elytra, 7-10 mm.; to tip of anal style, $8.25-13 \mathrm{~mm}$.

REMARKS.-This large species is readily distinguished from all other forms of Mordellini by the elytra markings and other characters. The color and markings differ slightly in some examples, and old specimens often become greasy, the color then appearing nearly black. C. A. Frost (1913: p. 126) gave a splendid account of this species and its larvae. It appears from February to August.

Previons Records.-Missouri (Major Long); central and western states (Leconte); southwestern Pennsylvania (Hamilton); Cincinnati, Ohio (Dury); Ames and Iowa City, Iowa (Wickham); Maspeth, New York (Shoemaker) ; Nyack, New York (Davis) ; Palisades, Van Cortlandt, New York (Nicolay); Lake, Vigo, and Posey counties, Indiana (Blatchley). 
Material examined.-Illinois: Elgin (Bristol); Quincy (I.U.); River Forest, Glen View, Evanston, Bowmanville, Edgebrook, Beverly Hills, Willow Springs, and Palos Park (Gerhard, Psota, Wolcott, Selinger, and Liljeblad).

Indiana : East Gary (Liljeblad).

Iowa : Grinnell (Stoner).

Kansas: Wallace County and Winfield (Knaus); Wabaunsee County (Anderson, K.U.).

Maine: Monmouth (Frost).

Massachusetts : Forest Hill (Wilcox) ; Lenox (Bradford coll., A.M.N.H.).

Michigan: Washtenaw County (Hubbell); Pentwater and Paw Paw Lake (Liljeblad).

Missouri : St. Louis (Liljeblad).

New Jersey: Trenton (J. W. Green).

New York: Ithaca and Perry (C.U.) ; Rochester (Leonard coll., C.U.) ; Flushing (A.M.N.H.).

North Carolina: Hereford County (Liljeblad coll.).

Ohio: Columbus (Liljeblad).

Pennsylvania: Overbrook, Darby, and Angora (J. W. Green).

\section{Glipa inflammata (Leconte)}

(Pl. II, Fig. 1)

Mordella inflammata Leconte, 1862, p. 46, Florida. Smith, 1882, pp. 81, 82.

DeSCRIPTION.-Cuneiform, male narrower than female; black with slight bluish reflection and marked with bright orange spots on thorax and elytra; head black with cinereous pubescence, base very narrowly fringed with light yellowish pubescence; thorax black with base, two dorsal projections on each side, and a narrow scalloped band near apex, with orange pubescence; elytra black with a large spot at base, surrounding scutellum and reaching sides, with bright orange pubescence, leaving a triangular black spot near humeral angle and a lunate spot one-fourth from apex with bright orange pubescence; underside black with more or less cinereous pubescence on sides; anal style black with cinereous hairs near base.

Head coarsely punctured; antennae short, reaching middle of thorax, iffth to tenth segments serrate; third and fourth segments narrow, fourth one-third shorter than third; fifth one-fourth longer than fourth, but much broader at apex; sixth to tenth each a little shorter than fifth, broadest at tip ; eleventh oval ; last segment of maxillary palpi scalene or nearly an isosceles triangle; eyes large, not reaching occiput, finely granulated, not hairy.

Pronotum about one-third broader than long; viewed from above evenly rounded to apex; viewed from side nearly straight; basal and apical angle obtuse; sculpture coarsely punctured in raised wavy lines; base in front of scutellum broadly rounded; scutellum triangular, broadly rounded at apex. 
Elytra more than twice as long as broad, with apices obliquely separated and obtusely pointed; no distinct margin, but set with short spinules; surface reticulated with well-raised punctures; underside coarsely punctured; anterior tarsi with second to fourth segments dilated; middle tibiae as long as all tarsal segments of same pair of legs; posterior tibiae with a subapical ridge near apical margin; anal style long and slender, pointed; males can readily be distinguished by the more pronounced arcuation of the anterior femora and tibiae.

Length : to apices of elytra, 8-9 mm.; to tip of anal style, 10-11.25 mm.

REMARKs.- This large and very prettily marked species can be separated readily from all the other known forms by the bright shiny orange spots at the base and near the apex of the elytra. It appears to be found only in Florida and has been reared from rotten oak logs by Hubbard. It appears in May.

Previous RECORDS.-Florida (Leconte).

MATERIAl eXÁmined.-Florida: Enterprise (six specimens).

\section{Glipa perlineata (Fall)}

(Pl. II, Fig. 2)

Mordella perlineata Fall, 1907, p. 254, New Mexico.

\section{DESCRIPTION.-}

Elongate, moderately attenuate, disk of elytra somewhat flattened; black, prothorax varied with cinereous nearly as in marginata, elytra with the suture and four narrow vittae on each cinereous, the inner one extending only to the middle or slightly beyond; beneath as in marginata.

Length: $4-4.5 \mathrm{~mm}$.

Remarks.-New Mexico (Clouderoft and Wootens), collected by Cockerell, Knaus, and Viereck.

This species is most nearly related to octopunctata and marginata, but differs markedly from the latter in its more flattened dorsum, the elytra being evidently less strongly arched when viewed in profile. The antennae are of the same type as in marginata but broader, the median segments widest, a little longer and more evidently serrate in the male, in which sex the outer sides (especially) of the segments bristle with short, fine, erect hairs. Last segment of the maxillary palpi broadly triangular, with the inner angle sharply defined in the male, more narrowly triangular, with the inner angle more or less rounded in the female. The head is relatively wider than in any other species of the genus now before me except octopunctata, being in the male as wide as the elytra at base. (Fall)

Through the courtesy of H. C. Fall I had the pleasure of examining one of his specimens (from which the accompanying drawing was made). In that specimen the eyes do not reach the occiput, and they are finely granulated and not hairy ; antennae with segments five to eleven more clavate than serrate; the fourth segment one-fourth shorter than the third; fifth to tenth about subequal; eleventh oval; last segment of maxillary palpi scalene triangular; scutellum broadly rounded at apex; elytra with surface reticulate 
and finely punctured; apex with fine but distinct margin; anterior tarsi with segments two to four slightly dilated; middle tibiae as long as all the tarsal segments of the same pair of legs; posterior tibiae with a short subapical ridge near the tip; anal style rather long.

On account of the position of the eyes, the species does not properly belong to Mordella. It seems to be very rare.

Previous Records.-Clouderoft and Wootens, New Mexico (Fall).

Material eXAMINed.-Arizona: no locality (U.S.N.M.).

New Mexico: no locality (Cockerell, Knaus, and Viereck).

\section{MORDELLA LINNAEUS}

Mordella Linnaeus, 1758, p. 420.

Sphalera Leconte, 1859, p. 17.

Descriptron.-Cuneiform; eyes reaching occiput and granulated; antennae more or less serrate or clavate; last segment of maxillary palpi long, more or less triangular; scutellum triangular; posterior tibiae and tarsi without ridges, except the short subapical one in former, anal style long and slender.

Remarks.-Sphalera Leconte, founded upon M. melaena Germar, is not sufficiently distinct. The specimens are usually on flowers (Pl. I, Fig. 1d).

This genus was erected by Linnaeus and based upon the species Mordella aculeata. The original description follows:

Antennae filiformis. Caput inflexum sub collo. Elytra dorsum curva apicem versus. Ante femora lamina lata ad basim abdominis.

Aculeata. 1. M. atra, abdomine spina terminato. Fn. Suec. 534, Mordella oblongo atra, cauda acules terminata.

Habitat in Europa.

\section{KEY TO SPECIES}

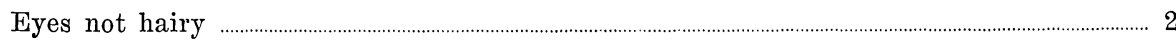

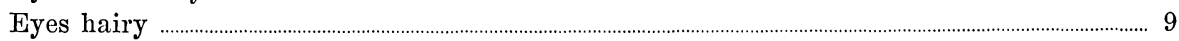

2. Elytra with strongly indicated markings …….................................................................................. 3

Elytra with faintly indicated markings ……..................................................................................... 4

Elytra without markings ....................................................................................................................... 6

3. Black; elytra with a curved and angulated band from base near scutellum, which on the two elytra combined forms a somewhat cordate spot at middle, a round spot at middle, and an oblique, triangular band on each elytron one-fourth from apex, connected with middle spot along suture, Pl. II, Fig. 3 .............................. (p. 32) knulli

Head and thorax black; elytra ferruginous with an oblique band from humerus downward one-third from base, a large spot near suture sometimes confluent with basal band, and a large angular band one-fourth from apex, not reaching suture, with yellowish cinereous pubescence; Pl. II, Fig. 4 .................... (p. 33) signata

Elytra in four colors-a large cupreous spot at base, a black, ornamented area at middle surrounded by a band of silvery pubescence, and apical third with peculiar yellowish or silvery pubescence; Pl. II, Fig. 5 ........................................ (p. 34) schwarzi

4. Elytra nearly uniformly dark, densely covered with cinereous pubescence and with a double whitish spot one-third from apex (p. 35) capillosa 
Elytra black with two spots on each elytron, one near base, other below middle, latter sometimes double; Pl. II, Fig. 6 .............................................. (p. 35) quadripunctata

Elytra with more or less oblique humeral markings 5

5. Elytra black, with suture and a very short, oblique vitta from humerus cinereous, 5.5 mm.; Pl. II, Fig. 7 (p. 37) lunulata

Elytra black, with a narrow sutural line and a rather long oblique vitta from humerus to below middle (sometimes indistinct), cinereous, $4.25 \mathrm{~mm}$; Pl. II, Fig. 8 (p. 38) obliqua

6. Antennae with seventh to tenth segments clavate 7

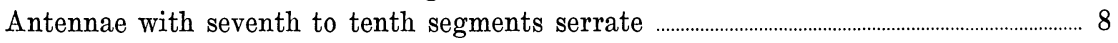

7. Entirely black, robust; pubescence nearly black, except base of anal style; third antennal segment longer than fourth, seventh to tenth clavate; Pl. II, Fig. 9

(p. 39) melaena

Black; pubescence dark reddish brown; third and fourth antennal segments equal in length, seventh to tenth serrate; Pl. II, Fig. 10

(p. 41) brevistylis

8 Antennae subserrate; elytra with gray pubescence at sides and along suture, leaves a dark area in the middle; Pl. III, Fig. 5 .................................................. (p. 41) cinereoatra

9. Elytra with one or more bands .................................................................................................................. 10

Elytra with spots or lines .................................................................................................................... 11

Elytra without markings …….................................................................................................................. 12

10. Elytra with two transverse cinereous bands, angulate near suture; Pl. III, Fig. 7 (p. 42) angulata

Elytra with an oblique band from humerus to near suture and a transverse spot behind middle; and suture cinereous; Pl. III, Fig. 2

(p. 43) insulata

11. Elytra with variable spots or blotches, sometimes with abbreviated short lines having cinereous pubescence; Pl. III, Fig. 4

(p. 44) marginata

Elytra with cinereous, pubescent markings forming lines ............... (p. 45) marginata v.

lineata

Elytra with suture more or less white ……………................................................................................ 15

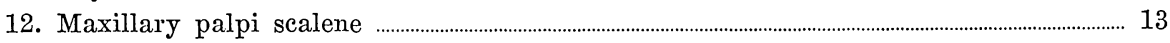

Maxillary palpi securiform ......................................................................................................................... 14

13. Entirely black; pubescence above brownish gray; Pl. III, Fig. 6 ................ (p. 45) atrata

Black; elytra conspicuously sprinkled with single, shining, cinereous or brown hairs

(p. 47) atrata var. lecontei

Black; very densely covered with brownish gray pubescence ........... (p. 47) fuscocinerea

14. Black, with brownish gray pubescence; antennal segments longer than broad, fourth segment longest; last segment of maxillary palpi securiform; Pl. III, Fig. 12

(p. 48) invisitata

15. Elytra black, with narrow white suture; last segment of maxillary palpi securiform (p. 49) immaculata

Black; elytra with narrow suture and two lateral vittae extending from humeri to apex, fulvo-cinereous; Pl. III, Fig. 8

(p. 49) deserta

Black; scutellum rounded at apex; second segment of maxillary palpi very large in male; Pl. III, Fig. 9 .............................................................................. (p. 50) albosuturalis

Black, with anterior and middle femora ferruginous; Pl. III, Fig. 10 ..... (p. 51) hubbsi Black; scutellum triangular, pointed at apex; PI. III, Fig. 11 ................ (p. 52) grandis

(The species angulata, immaculata, and deserta, have not been examined by me and have therefore been placed in the key according to their descriptions.) 


\section{Mordella knulli Liljeblad}

(Pl. II, Fig. 3)

Mordella lenulli Liljeblad, 1922, pp. 57, 58, Florida.

DESCRIPTION.-Cuneiform; ground black; head densely covered with fine argenteous pubescence except on a large median triangular spot where pubescence is less dense, showing through black ground; antennae and palpi black; eyes dull yellowish, transparent, with facets and margin black; entire margin of prothorax with argenteous pubescence except median third of apical margin, an angulated band one-third from apex and reaching side margins, a streak in middle from apex downward to middle band, and a streak each side of the middle from middle band downward but not quite reaching base, which forms five large spots of black pubescence; scutellum with argenteous pubescence; elytra each with black pubescence, except for a curved band reaching from scutellum outward and downward to about one-third from base and then extended outward to side margin (leaving a somewhat cordate black spot in middle of the two elytra and a somewhat angulated black spot at each humeral angle), a round spot in middle of each elytron very close to suture, and a sutural streak from near base, slightly widened to one-fourth from apex, where it is connected with an oblique triangular band that reaches margins, which are supplied with argenteous pubescence; underparts black, densely covered with argenteous pubescence, except for a black spot on posterior margin of mesosternum and metasternum; a similar denuded spot near hind coxal plate, and one near posterior lateral margin of each abdominal segment; legs with argenteous pubescence on femora and outer margin of tibiae and tarsi ; anal style black, with a little argenteous pubescence near base.

Head rather large, somewhat triangular in shape, finely punctured; eyes large, obovate, reaching occiput, finely granulated, not hairy but with long hairs below on edge; antennae strongly serrate or nearly clavate, not reaching base of thorax; first to fourth segments narrow; fifth to tenth nearly clavate; third and fourth equal in length; fifth one-fourth longer than fourth, and much wider at apex; sixth to tenth equal in length, each onefourth shorter than fifth; eleventh a little longer than tenth, rounded on inner angle; last segment of maxillary palpi scalene triangular.

Pronotum one-third broader than long, finely punctured; basal lobe in front of scutellum broadly rounded, sides feebly rounded and converging to apex; anterior and posterior angles acute; scutellum triangular.

Elytra more than twice as long as broad; surface reticulate with raised punctures; apex rounded and finely margined; middle tibiae longer than all tarsal segments of same pair of legs; anal style long, slender, pointed, and emarginate at apex.

Length : to apices of elytra, $7.5 \mathrm{~mm}$.; to tip of anal style, $10 \mathrm{~mm}$.; breadth, $3.5 \mathrm{~mm}$. 
REMARKs.-This large and very interesting species is known from a single specimen, presumably a female, collected on April 20, at La Belle, Florida, by J. N. Knull. It is entirely different in its markings from any other North American species of the genus, differing particularly in the distinct silvery pubescent pattern on the whole upper surface.

\section{Mordella signata Champion}

(Pl. II, Fig. 4)

Mordella signata Champion, 1891, p. 276, Mexico, Nicaragua. Liljeblad, 1922, p. 51.

DESCRIPTION.-Cuneiform; head black, with cinereous pubescence; prothorax black with yellowish cinereous pubescence becoming denser on sides; elytra with ground ferruginous, darker toward apex, marked with a rather broad oblique band from humerus downward one-third length of elytra near middle, a large oblong spot on inner side of this band near suture, sometimes confluent with basal band, and a large angular spot on disk beyond middle, with yellowish cinereous pubescence.

Head with surface aciculate, finely punctured; eyes reaching occiput, coarsely granulated and not hairy; antennae with first to fourth segments narrow; fifth to tenth serrate, fourth segment one-fourth shorter than third, fifth equal in length to fourth but much broader at apex; sixth a little shorter than fifth; seventh to tenth about equal in length, each a little shorter than sixth; eleventh oval; last segment of maxillary palpi elongate, scalene triangular.

Pronotum about one-third broader than long, closely and finely punctured; basal and apical angles obtuse; base in front of scutellum broad, nearly truncate; scutellum triangular, rather pointed.

Elytral sculpture reticulate, finely punctured; apex somewhat pointed and crenate; anterior tarsi with segments two to four dilated; middle tibiae as long as all tarsal segments of same pair of legs; posterior tibiae with a short subapical ridge near tip; anal style comparatively short, bluntly rounded at apex.

Length: to apices of elytra, $8 \mathrm{~mm}$.; to tip of anal style, $10 \mathrm{~mm}$.

REMARKs.-This is a large and well-marked species. The above description and plate figure were made from a specimen in my collection from Del Labo, New Mexico. A second specimen from Socorro County, New Mexico, collected by E. J. Gerhard, is in the Chicago Natural History Museum and agrees well with the other example. The characters of these two specimens differ slightly from those given in the original description, but as Champion cites two "variations," one from Mexico, it seems probable that the slight differences in coloration are not of specific significance. 


\title{
Mordella schwarzi, new species
}

\author{
(Pl. II, Fig. 5)
}

Type.-From Biscayne, Florida. Collected on May 14 by Hubbard and Schwarz; in the collection of the United States National Museum.

Paratype.-Same locality, May 17 ; in the Museum of Zoology, University of Michigan (Liljeblad coll.).

DEscription.-Elongate oval; head black with silvery gray pubescence, denser near base; clypeus, antennae, and palpi fusco-ferruginous, latter with second segment very pale; eyes black; pronotum cupreous, with entire basal lobe in front of scutellum and a streak extending upward each side of lobe to about one-third from apex with long argenteous pubescence; scutellum with argenteous pubescence; elytra with a large, circular, cupreous spot near base, which is connected to base near humeral angle; this spot almost entirely surrounded by long argenteous pubescence, broadest at base and near middle; suture black to a little below middle; a small black spot near scutellum and an irregular larger area at middle shaped somewhat like a bird with a long neck standing on uneven ground and surrounded by argenteous pubescence, which forms a narrow band below; beneath this the elytra are covered to tip with a peculiar yellowish, silvery gray pubescence, which in certain lights shows a somewhat ferruginous color; anal style argenteous; underside nearly black, with abdominal segments more or less ferruginous and with argenteous pubescence on pectus, sides of hind coxal plates, and sides of first abdominal segment.

Head large, minutely aciculate, and punctured; antennae short, reaching nearly to base of thorax; fifth to eighth segments slightly serrate; all segments nearly equal in length; fifth segment broadest; sixth to eleventh gradually diminishing in width; last segment of maxillary palpi elongate, apical side less than half as long as outer; second segment very broad, triangular. Eyes large, reaching occiput, not hairy, finely granulated, and with a very small emargination near antennae.

Pronotum one-fourth broader than long, broadest at middle, sides evenly rounded to apex, basal angles obtuse ; basal lobe in front of scutellum broadly rounded; surface minutely aciculate and punctured.

Elytra a little narrower than thorax at middle, sides converging a little to rounded apex; surface very finely aciculate. Middle tibiae as long as all tarsal segments of same pair of legs; anal style rather long and pointed.

Length: to apices of elytra, $3 \mathrm{~mm}$; to tip of anal style, $4 \mathrm{~mm}$; width, $1.5 \mathrm{~mm}$.

REMARKS.-This prettily decorated species is unlike any other of the North American Mordellidae and can readily be recognized by its quadricolored ornamentation. 


\section{Mordella capillosa, new name}

Mordella pubescens Liljeblad (nec Fabricius, 1798, p. 127), 1921, p. 182, Colorado.

Description.-Body moderately elongate, very slightly cuneiform; entirely covered with rather stiff, sericeous-cinereous pubescence; ground color mostly black, but elytra with a double whitish spot, situated at one-third the distance from apex to base.

Head very finely punctate; eyes reaching occiput, finely granulated, not hairy; antennae short, not reaching middle of thorax, with first to fourth segments narrow, fifth to tenth strongly serrate; third segment one-fifth longer than fourth; fifth one-fifth longer than fourth, but nearly twice as broad at apex; sixth to tenth segments about equal in length, each one-fourth shorter than fifth and very broad; eleventh segment one-third longer than tenth, sides slightly converging toward apex ; last segment of maxillary palpi an isosceles triangle.

Pronotum one-third broader than long, a little broader than elytra at base, evenly rounded from base to apex, hind angles obtuse; surface finely punctured, slightly canaliculate in middle near apex and with a faint fovea each side of it; base in front of scutellum very broadly rounded; scutellum triangular.

Elytra with surface reticulate, finely punctured; apex set with fine spines; no distinct margin; underside finely punctured; anterior tarsi with segments one to four dilated; middle tibiae as long as all tarsal segments of same pair of legs; posterior tibiae with a short subapical ridge near tip; anal style very short, comparatively broad, and blunt at tip.

Length: to apices of elytra, $6 \mathrm{~mm}$.; to tip of anal style, $7 \mathrm{~mm}$.

REMARKS.-This species is most nearly allied to Mordella quadripunctata (Say), from which it differs markedly in the much shorter form and in the color of the elytral pubescence, which is gray (more brownish black in $M$. quadripunctata).

Previous Records.-Littleton, Colorado (Liljeblad).

\section{Mordella quadripunctata (Say)}

(Pl. II, Fig. 6)

Anaspis quadripunctata Say, 1824, p. 276; 1859, p. 163.

Mordella quadripunctata Leconte, 1854 , p. 220 ; 1862, p. 46 . Smith, 1882, pp. 80, 82.

DESCRIPTION.-Cuneiform, robust; black, entirely covered with sericeous, brownish cinereous pubescence, more coarsely on head and thorax than on elytra; scutellum with silvery white pubescenec; elytra each with two cinereous argenteous spots, the larger exterior and somewhat linear, rather beyond middle, sometimes broken into two unequal spots, the smaller one obsolescent, subsutural, near base; lower parts with argenteous pubescence at sides of abdominal segments. 
Head minutely punctured; eyes moderately large, reaching occiput, finely granulated, not hairy; antennae short, reaching middle of thorax, first four segments small, fifth to eleventh clavate; third and fourth segments about equal in length; fifth a little longer than sixth and nearly twice as wide at apex as fourth; sixth to tenth about equal in length, clavate, forming an elongated club; eleventh one-third longer than tenth, tapering to apex; last segment of maxillary palpi scalene triangular.

Pronotum one-third broader than long, very little broader than elytra at base, evenly rounded and converging to apex; surface finely punctured; hind angles obtuse; base in front of scutellum broadly rounded; scutellum triangular.

Elytra with surface reticulate, more coarsely punctured, with two faintly indicated costae extending from humerus obliquely to slightly beyond middle; apex rounded, crenate, with no distinct margin; anterior tarsi with segments two to four dilated; middle tibiae as long as all tarsal segments of same pair of legs; posterior tibiae with a short subapical ridge near tip; inner edges of anterior femora bear long setae in male, only fine pubescence in female.

Length: to apices of elytra, 6-7 mm.; to tip of anal style, 7-8 $\mathrm{mm}$.

REMARKs.- This is one of the largest and most completely black species of Mordella. It is somewhat rare, but occasionally is numerous. It differs from the larger western species, $M$. hubbsi and $M$. grandis, by the cinereous pubescent spots on the elytra, the less strongly developed segments of the maxillary palpi, hairless eyes, and shorter anal style. The typical form has two spots on each elytron, but many specimens do not show the basal spots and some barely show the middle spot. Such examples, therefore, are difficult to distinguish from $M$. melaena, which has no spots, but the antennae are more clavate in the latter species and the apices of the elytra are finely margined, and the specimens are usually of smaller size. M. quadripunctata is found on flowers from June 22 to July 29.

Previous Records.-Missouri (Major Long') ; Kansas (Leconte) ; Kansas (Smith).

Material examined.-Colorado: Mount Lookout and Littleton (Frost).

Iowa: Indianola (Stoner).

Kansas: Belvidere, Kiowa County (Knaus).

Maine: Wales and Monmouth (Frost).

Manitoba: Aweme (Criddle).

Michigan : Sand Point, Huron County (Hubbell).

New York: Cranberry Lake (Hatch).

West Virginia: White Sulphur Springs (Frost).

Wisconsin: Worden Township, Clark County (A.M.N.H.). 


\section{Mordella lunulata Hellmuth}

(Pl. II, Fig. 7)

Mordella lunulata Hellmuth, 1865, p. 96, Illinois. Smith, 1882, pp. 81, 83. Blatchley, 1910, pp. 1312, 1313.

DESCRIPTION.-Cuneiform, black, with cinereous markings; head black, except mentum and four basal segments of antennae, which are a little fuscous; palpi black; prothorax black with cinereous pubescence at base, on a short abbreviated line near basal angle, a narrow lateral margin, and apical angle; scutellum cinereous pubescent; elytra black, with suture and a short oblique humeral vitta gray; underside black, with cinereous pubescence at sides and at base of abdominal segments; anal style black, with cinereous pubescence at base.

Head with surface aciculate, minutely punctured; eyes reaching occiput, finely granulated, not hairy; antennae with first to fourth segments narrow; fifth to tenth broadly serrate; fourth segment a little shorter than third; fifth to tenth about subequal in length, each a little longer than fourth but much broader at apex; last segment of maxillary palpi scalene triangular.

Pronotum one-fourth broader than long, finely punctured; basal and apical angles obtuse; base in front of scutellum broadly rounded; scutellum subtruncate at apex.

Elytra with surface reticulate, finely punctured; apex with distinct margin; anterior tarsi with segments two to four dilated; middle tibiae as long as all tarsal segments of same pair of legs; posterior tibiae with a short subapical ridge near tip ; anal style short, pointed ; last abdominal segment much longer in male than in female.

Length : to apices of elytra, $4.5 \mathrm{~mm}$.; to tip of anal style, $5.5 \mathrm{~mm}$.

REMARKs.-This species is rather rare. M. obliqua Leconte was considered to be the same as this species by Smith (1882: 83), but it can be readily separated from that species by its more elongate form, the much broader segments of its antennae, its stronger and more silvery pubescent sutural line, its finer silky appearance, and its short humeral vittae. It is usually present on flowers and appears from June 8 to September 1.

Previous Records.-Illinois (Hellmuth) ; Maryland, Michigan, Virginia, and Illinois (Leconte and Smith); Cincinnati, Ohio (Dury); Fort Montgomery, New York (Davis).

Material examined.-Colorado: Denver, June 1 (I.U.).

Connecticut: Lyme (Kirk and Champlain).

District of Columbia: June 20 (Middleton, U.S.N.M.).

Illinois : Ravinia (Liljeblad) ; Riverside (Selinger) ; Palos Park and Willow Springs (Gerhard, Wolcott, and Liljeblad).

Iowa: Dubuque (Stoner).

Maryland: Odenton (Dietrich). 
Massachusetts : Essex County, Sherborn, and Framingham (Frost).

Michigan : Ann Arbor, Washtenaw County (Hubbell, U.M.).

New Jersey : Phillipsburg (J. W. Green).

New York : Lake Keuka (C.U.).

Pennsylvania: Speeceville, Jeannette, and Mechanicsburg (Knull).

Ohio : Kent (Wendellke, C.U.).

\section{Mordella obliqua Leconte}

(Pl. II. Fig. 8)

Mordella obliqua Leconte, 1878, p. 428, Maryland. Liljeblad, 1921, p. 183.

DESCRIPTION.-Cuneiform, black, with cinereous markings; head black, covered with cinereous pubescence; antennae black or fuscous, more fuscotestaceous in female; palpi fusco-testaceous; thorax black, with two more or less distinct cinereous pubescent vittae on each side, starting from base and curving outward to about middle; rest of thorax with fine gray or brownish gray pubescence; scutellum cinereous; elytra black, with cinereous pubescence in a very narrow sutural line and an oblique vitta from humerus to a little below middle, where it becomes obsolete; underside black, with cinereous pubescence, more dense and silvery at sides of abdominal segments ; anal style black, silvery pubescent at base.

Head minutely punctured; eyes reaching occiput, finely granulated, not hairy ; antennae short, reaching base of thorax ; first to fourth segments narrow, fifth to tenth serrate; third segment a little shorter than fourth; fifth segment one-third longer than fourth, much broader at apex; sixth to tenth subequal, each about one-fourth shorter than fifth ; last segment of maxillary palpi scalene triangular, a trifle broader in female, with inner angle more rounded.

Pronotum one-third broader than long, finely punctured, sides very slightly curved, basal and apical angles obtuse; base in front of scutellum broadly rounded; scutellum triangular, broad, and slightly rounded at tip.

Elytra with surface reticulate, rather coarsely punctured, apex rounded with slightly beaded margin; anterior tarsi with segments two to four dilated; middle tibiae about as long as all tarsal segments of same pair of legs; posterior tibiae with a short subapical ridge near tip; anal style long, pointed; male with last abdominal segment longer, palpi more strongly angular, and anterior femora and tibiae more curved, with setae on inner side.

Length: to apices of elytra, $2.75-3 \mathrm{~mm}$.; to tip of anal style, $4-4.25 \mathrm{~mm}$.

REMARKS. - This species is rare. It was wrongly placed by Smith (1882: 80,83 ) in synonymy with $M$. lunulata. It resembles the latter to some extent in color, but is much shorter in form and has narrower antennae. It also resembles $M$. marginata in form, but the markings on the elytra are more or 
less spotted in that species. The oblique vitta on the elytra is, in some specimens, indistinct, but it is more or less indicated at the humerus. In fully colored examples it should run obliquely downward from the humerus to a little below the middle. This insect appears from May 18 to August 2.

I could not locate the type of this species in Leconte's collection, but found three specimens of it placed as M. lunulata. Perhaps these had been removed from obliqua after it was (erroneously) placed in synonymy with lunulata.

Previous ReCords.-Maryland (Zimmerman); Detroit, Michigan (Schwarz); Odenton, Maryland (Dietrich); Berrien County, Michigan (Hubbell).

Material examined.-Georgia : Spring Creek (Bradley).

Illinois : no locality (Liljeblad coll.).

New Jersey : Jamesburg (Liljeblad coll.).

New York : Flatbush, June 27 (Zabriskie, A.M.N.H.).

Pennsylvania: Enterline, Dauphin, and Ohio Pl. (Knull); Roberts (Bradley).

Virginia : Cape Charles (Knull).

\section{Mordella melaena Germar}

(Pl. II, Fig. 9)

Mordella melaena Germar, 1824, p. 169.

Sphalera melaena Leconte, 1859, p. 17.

Mordella melaena Leconte, 1862, p. 46. Smith, 1882, pp. 80, 82. Champion, 1891, p. 272. Blatchley, 1910, p. 1312. Liljeblad, 1922, p. 52.

DESCRIPTION.-Cuneiform, robust; black, upper surface entirely covered with fine sericeous, brownish cinereous pubescence (nearly black in some specimens); base of anal style with cinereous pubescence at base; lower parts black with cinereous argenteous pubescence at sides of abdominal segments.

Head comparatively large, minutely punctured; eyes reaching the occiput, finely granulated, rounded in male, more oval in female, not hairy; antennae with first to fourth segments slender; fifth to eleventh strongly serrate, or nearly clavate, forming an elongated club; third segment a little longer than fourth, which is a little broader at apex; fifth one-fourth longer than sixth; sixth to tenth equal in length; eleventh longer than tenth, triangular, rounded on inner and apical angles ; last segment of maxillary palpi scalene triangular, more rounded on inner angle in female than in male.

Pronotum one-third broader than long, rather finely punctate, broadest a little before base, evenly rounded and converging to apex, its base at middle broadly rounded in front of triangular scutellum.

Elytra a little narrower at base than thorax, sides at middle slightly sinuate and tapering to apex, surface reticulate with deep punctures, apex finely margined; anterior tarsi with segments one to four slightly dilated; 
middle tibiae as long as all tarsal segments of same pair of legs; posterior tibiae with a short, subapical ridge near tip; anal style short and blunt at tip.

Length : to apices of elytra, 5-6.5 mm.; to tip of anal style, 6-7.5 mm.

REMARKS.-This, also, is one of the rarer species; it is usually on flowers of many species. It appears to be closely allied to $M$. quadripunctata, but may be readily distinguished from it by the absence of the cinereous spots on the elytra. Care must be taken to avoid confusion of this species with $M$. grandis, which it closely resembles; in that species, however, the antennae are much longer, more serrate and less clavate, and the suture has more or less silvery pubescence. The same characters also differentiate Melaena from two smaller western species, albosuturalis and hubbsi. The best character by which melaena may be separated from atrata is the form of the antennae, which are more clavate, the outer segments being more dilated and compact, rather than serrate; further, the scutellum is more sharply triangular, and the anal style is always short and blunt at the tip, not long and slender. The insect appears from June 7 to September 13.

Previous REcoRDS.-Central, southern, and western (?) states (Leconte), southern Virginia (Horn); Wallace County, Kansas, and Dome Rock, Platte Canyon, Colorado (Snow); Adirondack Mountains, New York (Smith); Custer County, Colorado (Cockerell); Sparrow Lake, Ontario, Canada (Hamilton); southwestern Pennsylvania (Hamilton); South Fork of San Miguel and the Canyon of Big Blue and Little Willow Creek, Colorado (Bowditch and Haywood) ; Beaver Brook, Colorado (Bowditch); Micawber Mine, Custer County, and West Cliff, Colorado (Cockerell) ; and Indiana, throughout the state (Blatchley).

Material examined.-Colorado: East Spanish Peak, July 25 (Gaige) and Mount Lookout, Golden, July 10 (Frost).

Connecticut: Cornwall, May 20 (Chamberlain).

Dakota: Black Hills (Wortman, A.M.N.H.).

District of Columbia: Washington, June 11 (U.S.N.M.).

Florida: Alachua County, May 18 (Walker, U.M.).

Illinois: Oregon, July 9 and Glen View, June 27 (Liljeblad), Savanna, July 26 (Hart, I.U.) ; Urbana, July 21 (Hucke, I.U.) ; Mahomet, June 30 (I.U.).

Iowa: McGregor, July 15 (Liljeblad).

Maine: Monmouth (Frost).

Manitoba: Aweme (Criddle).

Maryland: Hyattsville, August 27 (Knab, U.S.N.M.).

Massachusetts: Sudbury and Sherborn (Frost).

Michigan: Pentwater (Liljeblad); Portage Lake, Livingston County (Hubbs, U.M.).

New York: Ithaca (C.U.) ; Cranberry Lake (Hatch) ; Buffalo (U.S.N.M.). 
Ohio : Kent (Wendellke, C.U.).

Oklahoma: Wister, July 3 (H. S. Barber, U.S.N.M.).

Ontario: Gravenhurst, Muskoka District, June 24 (A.M.N.H.) ; Toronto (C.U.).

Texas: Alpine, June 28 (Wickham).

Virginia : Fredericksburg, June 5 (Richardson, U.S.N.M.).

Wisconsin: Delavan (Bristol) ; Stanley, July 14 (A.M.N.H.) ; Warden, Clark County, June 20 (Schmidt).

\section{Mordella brevistylis Liljeblad}

(Pl. II, Fig. 10)

Mordella brevistylis Liljeblad, 1922, pp. 56, 57.

DESCRIPTION.-Subcuneiform; black; both upper and lower surfaces with black or dark reddish brown pubescence; sides of breast, and first and second abdominal segments at sides with cinereous pubescence.

Head finely punctured; eyes large, rounded, very little or not at all sinuate in front, reaching occiput, rather coarsely granulated, not hairy; antennae with first to fourth segments narrow; fifth to tenth serrate; third and fourth equal in length, fourth widest; sixth to tenth about as wide as long, nearly alike in shape; fifth with sides straight; eleventh oval, a little longer than tenth; last segment of maxillary palpi scalene triangular.

Pronotum very little wider than elytra at base, one-fourth wider than long, widest a little before base, then evenly rounded to apex; base nearly truncate or very slightly emarginate in front of scutellum; scutellum triangular, broadly rounded at apex.

Elytra with surface reticulate, very finely punctured, no distinct margin; anterior tarsi with segments three to four very slightly dilated; middle tibiae as long as all tarsal segments of same pair of legs; posterior tibiae with a short subapical ridge near tip; anal style short, shorter than thorax and blunt at tip.

Length: to apices of elytra, $4.25 \mathrm{~mm}$.; to tip of anal style, $5.25 \mathrm{~mm}$.

Remarks.-This species somewhat resembles Mordella atrata Melsheimer, but is readily distinguishable by its more elongate form and the shorter, blunt anal style.

Previous Record.-New Mexico (Crew coll., C.U.).

\section{Mordella cinereoatra, new species}

(Pl. III, Fig. 5)

Txpe.-From Tampa, Florida. A male, collected on June 9 by Hubbard and Schwarz; in the collection of the United States National Museum.

Allotype.-A female, same data as type.

Paratypes.-One male and one female, same data as type; in the collection of the Museum of Zoology, University of Michigan. 
DEscription.-Nearly parallel, female more robust; entirely black or blackish brown; head and thorax with gray pubescence, the latter more dense at sides; elytra with gray pubescence at the sides and broadly along the suture, leaving a black area in the middle from base to apex and broadest at base.

Head large, about one-fifth narrower than the elytra at base, surface minutely aciculated and punctured; eyes finely granulated and with fine hairs, no emargination; antennae short, not reaching base of thorax, somewhat like Mordella marginata, but less serrate; segments eight to ten not at all serrate; last segment of the maxillary palpi broad, with the apical side twice as broad as the inner and slightly incurved.

Pronotum nearly twice as broad as long, surface more coarsely aciculated and with rather deep punctures; basal angles rounded; basal lobe at middle in front of scutellum broadly rounded.

Elytra nearly parallel to near the apex; surface like the pronotum; anal style short and rather broad to near the tip.

Length : to apices of elytra, $3-3.25 \mathrm{~mm}$; t to tip of anal style, $3.75-4 \mathrm{~mm}$.

REMARKs.-This species may easily be taken for Mordella fuscocinerea, but that species is longer in form, has the antennal segments five to ten serrate, the eyes broadly emarginate behind the antennae, and the pubescence uniform.

\section{Mordella angulata Leconte}

(Pl. III, Fig. 7)

Mordella angulata Leconte, 1878, p. 427, Florida. Smith, 1882, p. 81.

\section{DESCRIPTION.-}

Black, finely pubescent, elongate. Elytra with two cinereous, somewhat oblique, transverse spots, one at the anterior third, the other at the second third of the length; these spots are each connected at the inner end with an oblique line running backwards to the suture. Anal process long and slender.

Length: $2.7 \mathrm{~mm}$.

Lake Ashby, Florida, one specimen. Longer and narrower than the preceding ( $M$. fascifera), having the form of many Mordellistenae, or of Mordella discoidea. (Leconte)

REMARKs.-The type of this species, which I have examined, is in the Museum of Comparative Zoology and from this has been made a few notations as well as an outline of the pubescent spots on the elytra.

The form is like that of Mordella insulata. It is entirely black with grayish pubescence as follows : a narrow basal and scutellar streak; a broken band one-third from base, of which the inner part is somewhat angular near the suture, and an oblique band below the middle, not reaching margin or suture; antennae and anterior legs brownish.

This species is no doubt exceedingly rare, as no specimen except the type has been seen by me. 


\section{Mordella insulata Leconte}

(P1. III, Fig. 2)

Mordella insulata Leconte, 1859, p. 16, Kansas; 1862, p. 47. Smith, 1882, pp. 81, 83.

Description.-Subcuneiform; black, with sericeous markings on thorax and elytra; head black, with dense cinereous pubescence; antennae, palpi, and anterior legs testaceous; thorax black with cinereous pubescence at base, apex, and a long stripe each side of middle from base to apex; scutellum with cinereous pubescence; elytra black, with an oblique band from humerus almost to suture, angularly pointed downward; a complete sutural line, extended in well-marked specimens upward along base to humeral band, and a transverse spot behind middle, with sericeous cinereous pubescence; spot behind middle is markedly variable in shape and size in different specimens, no two of which seem to be alike; underside black, abdominal segments more or less reddish brown, with cinereous pubescence at sides; anal style black, with cinereous pubescence near base.

Head large, nearly as broad as elytra at base; surface aciculate and with minute punctures; eyes reaching occiput, finely granulated and hairy; antennae with first to fourth segments narrow; fifth to tenth serrate; fourth segment longer than third; fifth to tenth each slightly diminishing in length and fifth very little shorter than fourth; eleventh oval; last segment of maxillary palpi elongate, scalene triangular, differing a little in the two sexes, male shorter and more securiform in shape, female comparatively larger in all segments.

Pronotum about one-third broader than long, finely punctured; base and apical angles obtuse; base in front of scutellum broadly rounded; scutellum triangular, broadly rounded at tip.

Elytra narrower in male than in female; surface reticulate and finely punctured; apex rounded and with distinct margin; anterior tarsi with second to fourth segments slightly dilated; middle tibiae as long as all tarsal segments of same pair of legs; posterior tibiae with a short subapical ridge near tip ; anal style rather long and pointed; male distinguished from female by the much narrower form, and by having the last segment of maxillary palpi more securiform than scalene.

Length: to apices of elytra, 3.5-4.5 mm.; to tip of anal style, 5-6.5 mm.

REMARKs.-This is a well-marked species which can be readily distinguished by the entire sutural line; the rest of the markings somewhat resemble those of $G$. oculata, which, however, is much larger. The present species is rare in collections, and only a few specimens have come to hand for examination. It appears from June 24 to July 22.

Previous records.-Fort Riley, Kansas (Xanthus); Kansas (Leconte); Lawrence, Douglas County, Kansas (Snow); Galinas Cañon, New Mexico (Snow); Kansas and Texas (Smith). 
Material examined.-Arizona: no locality (C.U. and Morrison, U.S.N.M.).

Arkansas : Fayetteville (Knaus).

Colorado: Denver (Stoner).

Illinois : Quincy, July 2 (I.U.).

Kansas: Wyandotte (Warren) ; Douglas County, July 9 (Brown, K.U.) ; Hodgman, July 7 (K.U.).

Texas: Lexington, June (Birkmann).

\section{Mordella marginata Melsheimer}

(Pl. III, Figs. 3 and 4)

Mordella marginata Melsheimer, 1846, p. 312, Pennsylvania. Leconte, 1862, p. 47. Smith, 1882, pp. 81, 83. Blatchley, 1910, pp. 1312, 1313.

Description.-Cuneiform; black, with grayish pubescence; head black with more or less dense cinereous pubescence; antennae black, a little lighter at base; prothorax black with an entirely longitudinal narrow band each side of middle, an abbreviated band toward hind angles, and a spot or oblique abbreviated band on each side reaching margin at middle with cinereous or silvery pubescence; these markings are variable and in some specimens are only faintly indicated, but the basal part can always be seen in certain lights; scutellum silvery pubescent; elytra black with silvery or cinereous pubescence in spots (or blotches) or somewhat abbreviated lines, or both, being so variable that hardly two specimens are alike; underside black, varied with cinereous pubescence, more dense at sides and bases of abdominal segments; anal style black, silvery pubescent at base.

Head with surface aciculate, minutely punctured; eyes reaching occiput, finely granulated and covered with minute hairs; antennae with first to fourth segments narrow; fifth to tenth serrate; fourth segment a little shorter than third; fifth to tenth subequal, each triangular and each about as long as third; last segment of maxillary palpi scalene triangular, more rounded on inner side in female.

Pronotum one-third broader than long, finely punctured; base in front of scutellum broadly rounded; scutellum triangular, rounded at apex.

Elytra with surface reticulate, finely punctured; apex with distinct margin; anterior tarsi with segments two to four dilated; middle tibiae as long as all tarsal segments of same pair of legs; posterior tibiae with a short, subapical ridge near tip; anal style comparatively short, pointed.

Length : to apices of elytra, 3-3.5 mm.; to tip of anal style, 4-5.5 mm.

REMARKs. - This species is very abundant in the middle and eastern states, being found on flowers of many species. The markings are very variable. In the same locality certain specimens may have only a few spots or broken lines on the elytra, and on others the whole surface is covered 
with blotches, which are sometimes like fasciae, but the markings on the thorax are more constant. It is the most variable of all species of Mordella and is very common in collections. Melsheimer's supposed type of marginata in the Museum of Comparative Zoology, which has been examined by me, agrees with the above description. Mordella lineata Melsheimer (1845: 313) has the markings on the elytra in confluent lines and can be considered as only a variation of this species, since these markings are not constant. The present species appears from May to August.

Previous records.-Pennsylvania (Melsheimer) ; Atlantic Ocean to Kansas, Louisiana to Winnipeg (Leconte); United States (Smith); Sparrow Lake, Ontario (Hamilton) ; Sudbury District, Ontario (Evans) ; southwestern Pennsylvania (Hamilton); Cincinnati, Ohio (Dury); Ames, Iowa (Osborn); Iowa City and Independence, Iowa (Wickham); Indiana, throughout the state (Blatchley); and New York state (Nicolay).

Material EXAMINED.-I have examined specimens from more than one hundred and twenty-five localities, too numerous to mention except by reference to the following: Maine, New Hampshire, Massachusetts, Rhode Island, New York, Connecticut, New Jersey, Maryland, District of Columbia, Vermont, Pennsylvania, Michigan, Indiana, Illinois, Iowa, Virginia, West Virginia, North Carolina, Kansas, Tennessee, Louisiana, Florida, Texas, New Mexico, Nebraska, Colorado, southwestern Arizona, and Nova Scotia, Canada.

\section{Mordella marginata var. lineata Melsheimer}

Mordella lineata Melsheimer, 1846, p. 313, Pennsylvania. Leconte, 1862, p. 47.

\section{Description.-}

Black; elytra with four narrow longitudinal ashy lines. $1 \frac{1}{2} \mathrm{~L}$. long. Pennsylvania. Mordella lineata Melsh. Catal.

Black, antennae black; thorax pictured as in the preceding species: scutal yellowishsericeous; elytra with the sutural and lateral edges and four longitudinal, posteriorly abbreviated lines, ashy or yellowish; beneath and feet black, ashy sericeous; abdominal segments as the preceding species. (Melsheimer)

REMARKs.- - This variety differs from the typical form only in having the grayish pubescence forming four to six longitudinal lines, more or less abbreviated; otherwise it is identical with marginata. It is not so common as the typical marginata, but has about the same range.

\section{Mordella atrata Melsheimer}

(P1. III, Fig. 6)

Mordella scutellaris Fabricius, 1801, p. 123. Leconte, 1862, p. 46. Smith, 1882, pp. 80, 82. Blatchley, 1910, pp. 1312, 1313. Champion, 1891, p. 275.

Mordella atrata Melsheimer, 1846, p. 313, Pennsylvania. Liljeblad, 1922, p. 53. 
Description.-Cuneiform, more robust in female than in male; black, pubescence of upper surface brownish or very slightly cinereous, that of scutellum cinereous; that of lower parts brownish, sometimes nearly black; sides and anterior margin of abdominal segments and base of anal style with sericeous-cinereous hairs.

Head with surface aciculate, densely and minutely punctured; eyes moderately large and rounded (particularly in males), reaching occiput, finely granulated and with very short hairs; antennae with first to fourth segments slender; fifth to tenth serrate; third segment a little longer than fourth; fifth triangular, one-third longer than third and twice as broad at apex; sixth one-third shorter than fifth; seventh to tenth of uniform width, serrate, about as broad as long; eleventh constantly very little longer than tenth and rounded on inner side; last segment of maxillary palpi scalene triangular in male, inner angle rounded in female.

Pronotum one-third broader than long, a little broader than elytra at base, widest a little before base, then evenly rounded to apex, finely punctured; base broadly rounded in front of scutellum; basal angles obtuse; scutellum triangular, broadly rounded at tip.

Elytra with surface reticulate, moderately punctured; apex rounded, with fine but distinct margin; anterior tarsi with segments one to four slightly dilated; middle tibiae a little longer than first four segments of tarsi combined of same pair of legs; posterior tibiae with a short subapical ridge near tip.

Length : to apices of elytra, $3.5-4.5 \mathrm{~mm}$.; to tip of anal style, $5.5-6.5 \mathrm{~mm}$.

ReMarKs.-This is one of the most common species of Mordella. It is usually on flowers of many species and sometimes can be collected in hundreds by sweeping. It is, therefore, very common in collections. It occurs in nearly every state from Canada to Florida, except in the west, where M. albosuturalis takes its place. It varies in size and somewhat in pubescence, but not otherwise, and is comparatively easy to separate from the other black forms. It closely resembles Mordella atrata var. lecontei, which has the elytra sprinkled with single shining cinereous or sometimes brown hairs; it also resembles the western $M$. albosuturalis, but that species has the suture cinereous, the second joint of maxillary palpi much larger in the male, and the antennae more tapering to the tip.

This species formerly has been called Mordella scutellaris, but that name undoubtedly belongs to a South American insect, and therefore I have used the name atrata for the North American species (Liljeblad, 1922: 53) :

Since Fabricius (1801: 123) states in the original description of scutellaris that the head and thorax are ferruginous or rusty-red ("Caput et thorax ferrugineo paullo nitidula") and the elytra black, and gives as the type locality South America, whereas in the present North American species the color is wholly black, with gray or brownish pubescence, the writer cannot agree in regarding as available the name scutellaris. The oldest tenable name for the North American species here discussed appears to be Mordella atrata, for it best agrees with Melsheimer's original account of atrata. 
MATERIAL EXAMINED.-It has been recorded from many states by previous writers, who, however, did not separate it from the western forms. Consequently, I do not think it justifiable to mention these older ambiguous records. It is so common, however, that I have accumulated several pages of data, which are too numerous to mention beyond reference to Canada and the following states: Maine, Connecticut, Pennsylvania, Vermont, Massachusetts, New York, New Jersey, Maryland, North Carolina, Kansas, Virginia, Colorado, Michigan, Wisconsin, Iowa, Ohio, Illinois, Indiana, Missouri, Mississippi, Tennessee, and Florida.

\section{Mordella atrata var. lecontei Csiki}

Mordella irrorata Leconte, 1862, p. 46, Florida (nec Trost, 1801, p. 27). Smith, 1882, p. 82. Blatchley, 1910, p. 1313.

Mordella lecontei Csiki, 1915, p. 23. Liljeblad, 1922, pp. 53. 54.

DESCRIPTION.-Cuneiform, black; head and thorax rather closely covered with black and brownish or grayish brown pubescence; elytra with black pubescence, sparingly (sometimes rather closely) but conspicuously sprinkled with single, shining, cinereous or brown hairs; otherwise like Mordella atrata.

REMARKs.-This variety is rather common, but is not so common as is atrata. The single, shiny, pubescent hairs on the elytra vary much in density, but can easily be detected on fresh specimens. Leconte's type of Mordella irrorata from Baldwin, Florida, a male in the Museum of Comparative Zoology, has been examined by me and is doubtless a variety of the foregoing $M$. atrata. The insect appears from May 18 to August 19.

Previous REcords.-Southern and western states (Leconte) ; and New York state (Smith); Halifax, Nova Scotia, and Hastings and Soudbury counties, Ontario, Canada (Evans).

Material examined.-Pennsylvania, Maryland, Massachusetts, Maine, West Virginia, Ohio, Indiana, Illinois, Wisconsin, North Carolina, Georgia, and Texas.

\section{Mordella fuscocinerea Fall}

Mordella fuscocincrea Fall, 1907, p. 254, New Mexico.

\section{Description.-}

Rather slender, strongly cuneiform, black, clothed uniformly above with sericeous, brownish cinereous hair ; the scutellum slightly, the elytral suture not at all, paler. Beneath cinereous pubescent; a piceous spot near the posterior margin of the hind coxal plate and the ventral segments fuscous posteriorly, especially at the sides.

Length: $31-4 \frac{1}{4} \mathrm{~mm}$.

Alamogordo, New Mexico (Viereck).

Nearly allied to scutellaris, but narrower and more strongly attenuate posteriorly, and of quite a different aspect because of the much paler pubescence. The antennal and palpal structure is nearly as in scutellaris. The sexes differ only very slightly, the eyes 
being a trifle larger in the male, the antennae scarcely stouter or more serrate in the female sex, the outer joints (8-10) about as long as wide. (Fall)

REMarks.-I have not seen the type. A few specimens, however, have been received, including a female from Fall, that agree with the description. The species is rather rare in collections and is readily recognized by its form, which is like that of a male marginata, but it has the surface rather heavily covered with silky, brownish gray pubescence; the head is large, about as wide as the elytra at base; the eyes are large, with very short and fine hairs, scarcely visible in the male; the last segment of the maxillary palpi is scalene in the male, rounded on the inner angle in the female; pronotum one-third broader than long, with basal angles obtuse; the lobe at middle in front of scutellum broadly rounded; anterior tarsal segments a little dilated; middle tibiae about as long as all the tarsal segments of the same pair of legs.

Material examined.-New Mexico : no locality (Crew coll., C.U.).

Arizona: Winslow (R. and H.).

\section{Mordella invisitata, new species}

(Pl. III, Fig. 12)

Trpe.-From Alachua County, Florida. A male in the Museum of Zoology, University of Michigan (Liljeblad coll.), collected on April 29, 1923, by Alexander and Walker.

Description.-Cuneate; black, with brownish gray pubescence, except four basal segments of antennae and anterior legs, which have a slight shade of brown.

Head rather large, surface minutely aciculated and finely punctured; eyes comparatively small, nearly round, with a narrow margin, moderately granulated, hairy, not emarginated; antennae short, reaching to base of thorax, serrate and rather broad beyond fourth segment, which is the longest, nearly twice as long as third ; fifth a little shorter than fourth; sixth to tenth each very little shorter than fifth, eleventh oval; last segment of maxillary palpi strongly securiform, with dense setae on undersurface.

Pronotum one-third broader than long; surface with minute and fine punctures; basal angles rounded; basal lobe at middle broadly rounded; scutellum rounded at apex.

Elytra a little narrower than pronotum, gradually tapering to rounded apex; surface reticulated, finely punctured, and with a faint, oblique costa from humeral angle downward one-third length of elytra; anal style long.

Length: to apices of elytra, $5 \mathrm{~mm}$.; to tip of anal style, $7 \mathrm{~mm}$.

Remarks.-This species on superficial examination resembles any of the larger black species of Mordella, but differs considerably from them in the shape of the last segment of the maxillary palpi, which is very broad; the other segments are somewhat similar to those of Glipa oculata; the antennae also differ by having the segments longer than broad. 


\section{Mordella immaculata Smith}

Mordella immaculata Smith, 1883, p. 5, District of Columbia.

\section{DESCRIPTION.-}

Terminal point of maxillary palpi broad, securiform; slender; entirely black, suture narrowly clothed with white pubescence, else immaculate.

Length: $6 \mathrm{~mm}$.

Hab. D. C. No: 19.

This species is the most slender of those in this genus and is readily distinguished from the others by this character. The form of palpi allies it most nearly to insulata. (Smith)

REMarks.-This species is entirely unknown to me, and I have not been able to locate the type.

\section{Mordella deserta Casey (Pl. III, Fig. 8)}

Mordella deserta Casey, 1884, p. 186, Arizona.

\section{DESCRIPTION.-}

Form rather robust; sides nearly parallel. Pubescence very coarse, close, recumbent and sericeous, setiform, very pale fulvo-cinereous on the flanks of the head and pronotum, piceous on the middle portions of the disk; also fulvo-cinereous in two broad lateral vittae extending from the humeri of the elytra to the apex and slightly increasing in width through the basal third; also on the scutellum and very narrowly along the suture; on the remainder of the elytral surface dark piceous-brown by reflected light, dark reddish purple by transmitted light; integuments uniformly piceous-black, very finely feebly and closely punctate, much more finely so on the prothorax than on the elytra. Head slightly wider than long; interocular surface broadly and very evenly convex throughout; eyes continuous in curvature with it and somewhat large, rather finely granulated; anterior margin of the epistoma narrow and very feebly arcuate, slightly less than one-half as long as the distance between the eyes; last joint of the maxillary palpi more than twice as long as wide, so obliquely truncate as to be scalene in outline, truncated edge very broadly arcuate; antennae short, scarcely longer than the width of head, first and second joints nearly equal in length, shorter than the third, first four joints subcylindrical, five to ten decreasing in length, narrowed toward base, trapezoidal, the former slightly longer than wide, the latter distinctly transverse, eleventh longer than wide, oval in outline, obtusely rounded at tip, joints five to eleven strongly flattened. Prothorax one-third wider than long, rather strongly and evenly convex; sides feebly and evenily arcuate; apex very slightly shorter than the base, broadly and somewhat angularly arcuate, the latter strongly and abruptly arcuate through the middle third. Scutellum slightly wider than long, evenly and acutely rounded behind, sides feebly arcuate, surface flat, finely and asperately punctate. Elytra at base just visibly narrower than the pronotum; sides parallel and nearly straight for three-fourths the length from the humeri, thence rather obtusely rounded behind; each elytron evenly and rather acutely rounded at apex; disk conjointly very slightly more than twice as long as wide. Legs and undersurface of the body black, with fine fulvo-cinereous pubescence; posterior tarsi longer than the femora, first joint much longer than the next two together, slightly shorter than the tibiae; tibiae and first three tarsal joints densely fimbriate at tip with short, stout, equal spinules; claws feebly arcuate, not at all cleft nor pectinate, but having on the inner edge two or three very 
minute tuberculiform denticulations; spurs of posterior tibiae rather long, very stout, arcuate, straight and very unequal.

[Length:] From tip of anal style, $4.5 \mathrm{~mm}$.; width of pronotum $1.7 \mathrm{~mm}$.

Arizona, 1.

According to the table given by Mr. J. B. Smith, this species would enter the first of his groups in the second division of Mordella, and I see nothing there which will at all fit the above description. (Casey)

REMARKs.-Information has been kindly furnished me by Edward A. Chapin that the above description does not entirely agree with Casey's type in the United States National Museum. The pubescence of the head is uniform in coloration. The two broad lateral vittae end abruptly at about the basal three-fifths and do not extend to the apex as described. The suture is fulvocinereous only in the basal three-fifths. The sketch of the elytra was furnished by Chapin.

\section{Mordella albosuturalis Liljeblad}

(Pl. III, Fig. 9)

Mordella albosuturalis Liljeblad, 1922, p. 54, California.

Description.-Cuneiform, male usually narrower than female; color black, with fine reddish brown pubescence; basal margin of thorax and elytra, scutellum, and elytral suture with argenteous pubescence; underparts with cinereous pubescence, densest on sides and anterior margins of ventral segments.

Head shining, very minutely punctured; eyes reaching occiput, elongaterounded or egg-shaped, sinuate on upper side near antennal cavity in male (this sinuation obsolete in female), finely granulated and with fine hairs; antennae with first to fourth segments slender; fifth to tenth serrate; third and fourth equal in length, fourth widest; fifth about equal in length to fourth, but one-third broader at apex, with sides straight; sixth to tenth serrate, with inner sides rounded, sixth broadest, remainder diminishing slightly in width to tenth; eleventh segment one-third longer than tenth, more oval in shape; last segment of maxillary palpi elongate, scalene triangular in male, and with second segment much broader; female with last segment with inner side longer and angle more rounded.

Pronotum about one-third broader than long, very little wider than elytra, broadest near base, then evenly rounded to apex; finely punctured; its base in front of scutellum broadly rounded; scutellum triangular, rounded at apex, in male usually a little narrower than in female.

Elytra with surface reticulate and with fine punctures; apex rounded, with fine but distinct margin; anterior tarsi with segments one to four very slightly dilated; middle tibiae as long as all tarsal segments on same pair of legs ; posteriar tibiae with a short subapical ridge near tip.

Length : to apices of elytra, $3.25-5 \mathrm{~mm}$.; to tip of anal style, $5.5-6 \mathrm{~mm}$. 
Remarks.-This species somewhat resembles Mordella atrata, from which it differs by having the base and suture of the elytra with silvery pubescence, the outer segments of the antennae slightly tapering to apex, and the maxillary palpi more elongate, and by having the second segment of the maxillary palpi in the male much enlarged. It seems to occur only in the western states, where it has been taken on flowers of Heteromela arbutifolia and several composites. It is probably rather common, as several hundred specimens have been sent for examination. It appears from May to September.

Previous records.-The following localities in California: Mount Diablo, Blue Lakes, Carmel, and Jamul (Hubbs) ; Tule River (Daggett) ; Mariposa County (Nunenmacher) ; Paradise Valley (Bradley) ; Kings River (Beardsley); Sugar Pine, Madera County (Bradley); Hockett Meadow to Sequoia National Park, Los Gatos Canyon, Fresno County, and Felton (Bradley); Switzers Trail, San Gabriel Mountains (F. Grinnell, Jr.) ; Camp Baldy, Los Angeles County (Muchmore); Tulare County, Mount Lowe, Raymond, Palmas Spring (Frost); Giant Forest, Sequoia National Park (Bradley); Sherwood, Mendocino County (C.U.). Also from Josephine County, Oregon, and Esmeralda County, Nevada (Nunenmacher) ; Troy, Idaho (Mann); Glen, Montana (Adams); Bottineau, North Dakota (Hubbell).

Material examined.-British Columbia: Kaslo (Caudell, U.S.N.M.) ; Ainsworth (Currie, U.S.N.M.) ; Bear Lake (Caudell, U.S.N.M.).

California : Chiquito Creek, Madera County (Dietrich); Siskiyou County (U.S.N.M.) ; Mirror Lake, Yosemite (Miss E. W. Mank) ; Santa Cruz County (U.S.N.M.).

Canada : Beaverfoot Range, Rocky Mountains (Wenman coll. A.M.N.H.).

Colorado : Solida (Bruner, U.S.N.M.).

Idaho : Moscow (Piper, U.S.N.M.) ; Troy (I.U.).

Nevada: Ormsby County (Baker, U.S.N.M.) ; Kings Canyon, Ormsby County (St.U.).

Oregon : Gold Hill (Biedermann, U.S.N.M.).

Utah : Blue Springs, Lake Panguitch, and Wasatch Lake (Knaus).

Washington: Seattle (St.U.) ; Medical Lake (Shannon, U.S.N.M.).

Wyoming : National Park (U.S.N.M.).

\section{Mordella hubbsi Liljeblad}

(Pl. III, Fig. 10)

Mordella hubbsi Liljeblad, 1922, p. 55, California.

DESCRIPTION.-Cuneiform; color entirely black, iridescent, except the femora of anterior and middle legs, which are ferruginous; head and thorax with sericeous cinereous pubescence; elytra with black sericeous (sometimes a little more reddish brown) pubescence; basal margin of thorax, scutellum, and elytral suture with argenteous pubescence; underparts with cinereous 
pubescence, becoming more silvery at sides of mestosternum and abdominal segments; antennae dull red at base.

Head minutely punctured; eyes reaching occiput, rather large, rounded, and sinuate in front in male, more oval or egg-shaped with scarcely any sinuation in female, rather coarsely granulated and hairy; antennae with first to fourth segments narrow; fifth to tenth serrate; third segment onethird longer than fourth; fifth to tenth as wide as long, the fifth broadest; sixth to tenth slightly decreasing in width; eleventh little longer than tenth, oval; last segment of maxillary palpi scalene triangular in male, more rounded on inner angle in female; second segment very much enlarged in male.

Pronotum one-third broader than long, much wider than elytra at base, widest basally and evenly rounded, converging to apex; surface finely punctured, its base in front of scutellum broadly rounded; scutellum triangular.

Elytra with surface reticulate, finely punctured; apex finely margined; anterior tarsi with segments one to four dilated; middle tibiae nearly as long as all tarsal segments of same pair of legs; anal style long, blunt at tip, about one-half as long as elytra.

Length : to apices of elytra, 3.5-4.5 mm.; to tip of anal style, 5-6 mm.

REMARKs.- This species differs from the other black forms of the genus in the ferruginous color of the anterior and middle femora, and can easily be distinguished by this character. It appears from June 1 to August 1 . All of the known specimens have come from the western states.

Previous RECoRds.-The following localities in California: Carmel (Hubbs) ; Switzer's Trail, St. Gabriel Mountain (F. Grinnell, Jr.) ; Tulare County (Frost) ; Long Canyon, Mariposa County (Nunenmacher) ; Paradise Valley, King River (Beardsley) ; Kenworthy (Frost) ; Sherwood, Mendocino County (C.U.) ; Three Rivers, Giant Forest, Tulare County (Bradley); Coalinga, Fresno County (Bradley); Camp Baldy, Los Angeles County (Muchmore); Los Gatos Canyon, Fresno County (Bradley); Raymond and St. Gabriel Mountain (Frost).

Material examined.-California: Stevenson Creek (Dietrich) ; Los Angeles (Coquillet, U.S.N.M.) ; Cuyamachaka, San Diego County (A.M.N.H.) ; Dulzura (A.M.N.H.).

Idaho : Pocatello (U.S.N.M.).

\section{Mordella grandis Liljeblad}

(PI. III, Fig. 11)

Mordella grandis Liljeblad, 1922, p. 56, California, Oregon.

DESCRIPTION.-Cuneiform, more robust in female; entirely black; pubescence of upper surface very fine, sericeous black, with cinereous or brownish 
hairs intermixed; scutellum and elytral suture with argenteous pubescence; lower parts cinereous, sides of breast and abdominal segments more strongly argenteous pubescent.

Head densely and minutely punctured; eyes in male large, rounded, sinuate in front, in female more oval in shape, and less sinuate, reaching occiput, rather coarsely granulated, and hairy; antennae with first to fourth segments narrow; fifth to tenth serrate; third slightly longer than fourth, which is a little wider at apex; fifth to tenth each a little longer than broad; sixth widest; following segments slightly diminishing in width to tenth; eleventh longer than tenth, oval in shape in male (in female the fifth is a little longer than sixth and sixth to tenth are about as wide as long); last segment of maxillary palpi scalene triangular in male, more rounded on inner angle in female.

Pronotum densely and finely punctured, one-third wider than long, considerably wider than elytra at base, widest near base, and evenly rounded to apex; hind angles subacute; base broadly rounded in front of scutellum; scutellum large and triangular, more pointed in female than in male.

Elytra with surface reticulate, rather coarsely punctured; apex rounded, very finely margined; anterior tarsi with segments two to four slightly dilated; middle tibiae as long as all tarsal segments of same pair of legs; posterior tibiae with a short subapical ridge near tip; anal style as long as thorax, truncate at tip.

Length : to apices of elytra, 4-5.5 mm.; to tip of anal style, 6-7 mm.

REMARKs.-This species might readily be confused with Mordella melaena Germar, on account of its size and general appearance. It can best be separated from that species by the form of the antennae, which are longer, narrower (not clavate), and slightly tapering from the sixth segment, and by the silvery sutural line and the longer and narrower anal style. It is also closely allied to Mordella hubbsi Liljeblad, but the anterior and middle femora are entirely black, not ferruginous. It appears from May 17 to July 30.

Previous Records.-The following localities in California: Mariposa County (Nunenmacher); Tulare County (Frost) ; Long Canyon, Los Gatos Canyon, Fresno County (Bradley) ; Sherwood, Mendocino County (C.U.) ; Camp Baldy, Los Angeles County (Muchmore) ; Paradise Park, Kings River (Beardsley) ; Sonoma County (C.U.) ; Kaweah (Hopping) ; and Pendelton, Oregon.

Material examined-California: San Francisquito Creek (St.U.); Chiquito Creek, Madera County, and Stevenson Creek, Fresno County (Dietrich) ; San Gabriel, Los Angeles (U.S.N.M.) ; Santa Anna River (I.U.). 


\section{TOMOXIA COSTA}

Tomoxia Costa, 1854, p. 8.

DESCRIPTION.-The principal characters of this genus as given by Costa are as follows: "Abdomen postice aculeo terminatum. Antennae serratae, articulo ultimo oblique truncato-emarginato, apice acuto. Tarsi medii tibia multo longiores. Unguiculi subtus dentati' (Costa).

Remarks. - The above description was based upon a single species, Tomoxia bucephala Costa (1854:8), which afterward was found to be the same as Mordella biguttata Gyllenhal (1827: 520), described twenty-seven years before. Two variations also have been described, Mordella fasciata Paykull (1800: 455) and Tomoxia sericea Mulsant (1856:324). Only one species, up to the present time, has been described from Europe.

The principal generic characters of Tomoxia, according to Costa, Lacordaire, Leconte, Smith, Champion, and Schilsky are as follows: form cuneiform; antennae serrate; eyes finely granulated ("eyes not reaching the occiput"-Smith); last segment of the maxillary palpi more or less elongate; scutellum large, square, transverse ("emarginate"-Leconte and Smith) ; posterior tibiae without ridges, except the short subapical one; anal style short, obtuse.

The only disagreement shown by previous writers on the separation of Tomoxia from Mordella seems to be with regard to the form of the last segment of the antennae (Costa) and the form of the scutellum and the anal style (various authors). The scutellum is said by some to be transversely emarginate behind in Tomoxia, triangular in Mordella, and the anal style is said to be short and obtuse in Tomoxia and long and slender in Mordella. These generic characters are not shown by all the North American species placed in Tomoxia, and in the European species the scutellum is transverse and nearly truncate at the apex. Only one North American species, Tomoxia inclusa Leconte, resembles the European species in this respect. T. bidentata Say and lineella Leconte have the scutellum very strongly or deeply emarginate, with nearly an acute point at each side. This is the real form of the visible scutellum with the pubescence denuded; with the pubescence in place, the form appears a little different, being rather more rounded at the apex.

In European species the eyes reach the occiput, as in the North American lineella and inclusa, but in bidentata the eyes do not reach the occiput.

The posterior legs on the European species are like those of North American forms as far as the subapical ridge on the tibiae is concerned. All previous writers, however, have entirely overlooked an almost entire, dorsal, carinated ridge near the outer margin of the tibiae and the first segment of the tarsi, which is plainly visible in the European Tomoxia biguttata. This is the same kind of marginal ridge that is found in the genus Glipodes 
as well as in the European genus Conalia (except that it does not reach the tip in Tomoxia). Although not mentioned in the original description, this carinated ridge is distinctly evident in the North American Tomoxia lineella and inclusa, but is not found in Tomoxia bidentata.

If this ridge is of generic importance in the genus Glipodes, why not also in Tomoxia? The fact that the subapical ridge is present in Tomoxia and not in Glipodes should not invalidate the dorsal carinated ridge when present. It is a more important character than any other mentioned, and as a consequence of its being in the genotype, Tomoxia biguttata, one of the North American species, Tomoxia bidentata Say, will have to be placed in some other genus, and six of the species heretofore included in the genus Mordella will have to be placed in Tomoxia. The carinated ridges mentioned above are not mere ridges of spinules or coarse pubescence. If the pubescence is removed, a real cutaneous elevation that constitutes a structural ridge on the tibiae will be seen.

In view of the above facts, I redescribe the genus Tomoxia as follows: form cuneate; color generally blackish or brownish, but sometimes more striking, in bands or spots, with irregularly diffused pubescence; antennae with fifth to tenth segments more or less serrate; eyes oval, reaching the occiput, somewhat finely granulated; last segment of maxillary palpi more or less elongate; scutellum variable in shape, either truncate, emarginate, or rounded at apex; anal style comparatively short, blunt at tip, in some species rather long and slender; posterior tibiae with a short, subapical ridge, about parallel with the apical margin, and with a carinated ridge along the outer dorsal edge ; first segment of posterior tarsi also with a similar dorsal carinated ridge along the outer margin, less strongly developed (Pl. I, Fig. 1e).

\section{KEY TO SPECIES}

Anterior tarsal segments not dilated 2

Anterior tarsi with fourth segment dilated ……………………………………………………..................... 5

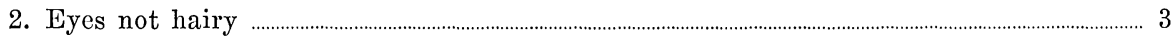

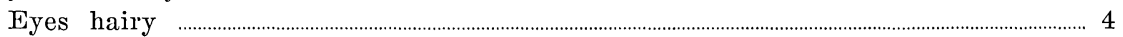

3. Last segment of maxillary palpi elongate oval; black; elytra with a broad basal fascia (sometimes formed in two narrow bands), a spot behind middle, a narrow band near apex, and suture, partly cinereous; Pl. III, Fig. 13 ......................... (p. 56) inclusa

Last segment of maxillary palpi securiform; blackish; thorax and elytra sprinkled with small rounded spots of cinereous or silvery pubescence; elytra usually with a band of similar pubescence behind middle, composed of confluent spots; Pl. III, Fig. 14 (p. 57) borealis

4. Last segment of maxillary palpi an isosceles triangle; black or brownish; elytra with narrow lines, a spot at middle sometimes like two confluent lines and a spot near apex, cinereous ; Pl. III, Fig. 16 (p. 58) lineella

Last segment of maxillary palpi scalene triangular; black; elytra with a broad band before middle and another at apex, with cinereous pubescence; Pl. III, Fig. 15 (p. 60) fascifera 
Last segment of maxillary palpi scalene triangular; elytra with two bands (one near base and one at middle) and apex, cinereous; Pl. III, Fig. 17 ........ (p. 61) undulata

Last segment of maxillary palpi elongate oval; black or dark reddish brown; elytra with numerous spots of short yellowish or gray hairs, a larger spot near base and a dentate band behind middle, and apex cinereous; Pl. III, Fig. 1 ........ (p. 62) serval

5. Maxillary palpi securiform

Maxillary palpi boat-shaped or hammer-shaped in male

Black; elytra with three bands of cinereous pubescence, one near base, one a little before middle and one one-third from apex; Pl. III, Fig. 19 (p. 63) triloba

Black; elytra with a rufous humeral spot, a narrow oblique streak from scutellum to near center, two spots sometimes confluent at middle, and a band near apex, cinereous; Pl. III, Fig. 20 (p. 65) carinata

7. Last segment of maxillary palpi boat-shaped or hammer-shaped in male, securiform in female; black; thorax yellow, with a large triangular black spot; elytra with an oblique humeral vitta, connected with a band before middle, another band behind middle, apex, margin, and suture behind second band, yellow; Pl. III, Fig. 18 (p. 66) discoidea

Elytra with a transverse spot before and another spot behind middle, yellow; thorax either black or yellow

(p. 67) discoidea var. flaviventris

\section{Tomoxia inclusa Leconte}

(Pl. III, Fig. 13)

Tomoxia inclusa Leconte, 1862, p. 45, western states. Smith, 1882, pp. 79, 80 .

DesCRIPTION.-Cuneiform, rather short, a little narrower in male than in female; black, except antennae, palpi, and anterior legs, which are more or less dark brown; head with fine grayish pubescence; thorax with more or less diffused grayish pubescent markings consisting of a streak each side of middle from base nearly to apex, a curved line from side margin upward to apex, and a short line connected with this one near middle, extending upward to margin; elytra with a more or less broken sutural line (which sometimes forms an elongated spot near scutellum, pointed upward, and at apex connected with a narrow band to side margin), a double oblique narrow band from humeri inward to near sutural mark, and a more or less triangular spot behind middle, with cinereous pubescence; underside black, with cinereous pubescence at sides of mesosternum and abdominal segments; anal style with cinereous pubescence near base.

Head rather large, sinuate behind at middle, finely punctured; eyes large, finely granulated, not hairy; fifth to tenth antennal segments serrate; last segment of maxillary palpi elongate oval in male, more oval or rounded in female.

Pronotum twice as broad as long, when viewed from above, evenly rounded from base to apex; basal angles acute; base in front of scutellum slightly emarginate or nearly truncate; surface finely reticulate and punctured; scutellum broad, very slightly emarginated at apex, and with long hairs. 
Elytra one-third broader at base than apex, which is rounded; surface reticulate and rather coarsely punctured, especially near base; anterior tarsal segments not dilated; anal style short and truncate at tip; anterior femora and tibiae more curved in male and with long hairs on inner side.

Length : to apices of elytra, $4.25 \mathrm{~mm}$.; to tip of anal style, $5 \mathrm{~mm}$.

REMARKS.-This species is most nearly allied to the European Tomoxia biguttata Gyllenhal and is rather rare. The grayish pubescent markings on the thorax and elytra vary to some extent; in some specimens they are more or less diffused. I have never seen a specimen with the whole suture grayish nor one from the western states, although Leconte in his description mentioned both. The supposed type, a male, in the Museum of Comparative Zoology, has a yellow tag which, according to the color key, indicates Central Valley, Illinois. The locality, "western states," given by Leconte in his description, may be a typographical error; if not, the specimen mentioned cannot be the type, although it agrees with the description. The species appears from June to August.

Previous RECORDS.- "Western (?) states" (Leconte); southwestern Pennsylvania (Hamilton); Catskill Mountains, New York (Nicolay).

Material eXAmined.-Illinois : Willow Springs, July 1 (Gerhard) ; Edgebrook, July 14 (Liljeblad).

Maine: Monmouth, July 8 (Frost).

Maryland: Plummers Island, June 28 (U.S.N.M.).

Michigan : Paw Paw Lake, July 22 (Liljeblad); Pigeon, Huron County, July 1 (Hussey, U.M.).

New Hampshire: Hampton (Shaw) and Durham, June 28 (I.U.).

New York: Rochester Junction, June 6 (Leonard, Crew coll., C.U.).

Ontario : Toronto, July 10 (Crew coll., C.U.).

Pennsylvania: Jeannette and Charter Oak (Knull).

Vermont : Middleburg, July 1 (Emerton).

\section{Tomoxia borealis (Leconte)}

(Pl. III, Fig. 14)

Mordella borealis Leconte, 1862, p. 46, northern states. Smith, 1882, pp. 80, 82. Blatchley, 1910, p. 1311.

DESCRIPTION.-Subcuneate; black, antennae and palpi reddish brown, densely covered with reddish brown pubescence, a little darker in some specimens; thorax, elytra, and anal style sprinkled with small rounded spots of silvery white pubescence, elytra with a rather broad band behind middle, not reaching suture; in female these spots are less indicated.

Head moderately large; eyes nearly obovate, reaching occiput, finely granulated, not hairy; antennae with first to fourth segments narrow; fifth to tenth strongly serrate; last segment of maxillary palpi securiform. 
Pronotum nearly twice as broad as long, a little broader than elytra at base, base at middle in front of scutellum broadly rounded; basal angles obtuse; surface minutely punctured.

Elytra very minutely aciculate and punctured, apex subtruncate with fine, distinct margin; anterior tarsal segments not dilated; middle tibiae longer than all tarsal segments of same pair of legs; posterior tibiae with a carinated dorsal ridge along outer edge, first segment of posterior tarsi with a similar carinated ridge, but less developed; anal style very little longer than last abdominal segment, bluntly pointed at tip; in male last abdominal segment cleft at middle to one-fourth from apex, broader and nearly truncate in female.

Length: to apices of elytra, $3-4 \mathrm{~mm}$.; to tip of anal style, $3.75-4.75 \mathrm{~mm}$.

REMARKs.-This species is readily recognized by the small silvery spots sprinkled over the upper surface. It resembles to some extent Tomoxia serval, but can be easily separated from that species by the silvery band below the middle. This band is only faintly indicated or is entirely wanting in some specimens, but the spots that surround this area are visible. The supposed type of this species, in the Museum of Comparative Zoology, has been examined by me, and it agrees with the above description. This insect is rather rare in collections. It appears from June to September.

Previous REcords.-Northern states (Leconte); Sudbury District, Ontario, Canada (Evans); Leadville, Colorado (Wickham); Cincinnati, Ohio (Dury) ; Catskill Mountains, New York (Pearsall).

Material examined.-British Columbia: Terrace, August 19 (Mrs. Hippisley) ; Bear Lake, July 20 (Caudell, U.S.N.M.).

Colorado: Fraser, July 1-5 (Frost).

Illinois : Algonquin (Nason coll., I.S.N.H.S.).

Maine : Monmouth, September 2 (Frost).

Michigan: Ann Arbor, June 10, and Huron Mountains, Marquette County, July 14 (Hubbell).

New Brunswick: Bathurst, June 21 (Knull).

New York: Cranberry Lake (Drake).

Ontario: Macdiarmid Lake, Nipigon, July 17 (Bigelow).

Pennsylvania : Manayunk (Liljeblad coll.).

Quebec: Lake Opasatika (Knull).

\section{Tomoxia lineella Leconte}

(Pl. III, Fig. 16)

Tomoxia lineella Leconte, 1862, p. 45, middle states. Smith, 1882, p. 79 . Linell, 1887 p. 171. Blatchley, 1910, p. 1311. Frost, 1913, p. 126.

DESCRIPTION.-Cuneiform, usually a little broader in female; color variable, in some specimens entirely black, in others reddish brown; antennae, 
palpi, and anterior legs ferruginous; middle legs more fuscous; posterior leg's fuscous, with cinereous or silvery gray pubescence; head rather densely covered with gray or silvery pubescence; thorax with base and a line each side of middle from base to apex (lateral markings more or less irregularly diffused), with gray or silvery pubescence; elytra with suture, two slightly oblique vittae from base to middle or a little below (sometimes with one or two additional vittae which, if present, are more or less abbreviated), each broadest at base, a double linear, sometimes nearly square, fascia a little below middle (in some specimens this fascia extends upward like broken lines) and a spot connected with sutural line near apex, with gray or silvery pubescence; underside with sides and base of abdominal segments covered with gray pubescence; anal style with gray pubescence at base.

Head large, nearly as broad as elytra at base, finely punctured; eyes large, finely granulated, hairy; antennae slender with fifth to tenth segments serrate; last segment of maxillary palpi on isosceles triangle with outer and apical sides about equal.

Pronotum one-third broader than long, broader than elytra at base, more coarsely punctured and reticulate; base in front of scutellum broad and slightly emarginate; basal angles acute; scutellum transverse, rather deeply emarginate, with apical angles acute.

Elytra cuneate; sculpture reticulate with rather coarse and deep punctures; apices separately rounded and with distinct margin; anterior tarsal segments not dilated; middle tibiae as long as first three segments of same pair of legs; posterior tibiae with usual subapical ridge, and with a rather strongly carinated dorsal ridge along outer margin; first segment of posterior tarsi also with a similar carinated ridge; anal style rather short, stout, and blunt at tip; the male of this species can be recognized by the more slender form and more pronounced arcuation of anterior tibiae, inner face set with erect hairs.

Length : to apices of elytra, 5-7.25 mm.; to tip of anal style, $6.75-8 \mathrm{~mm}$.

REMARKs.- This rather handsomely marked species is quite abundant in certain localities; on one occasion at Glen View, Illinois, I collected fortytwo specimens. It appears from early June to July and is usually on dead trees, such as elm, linden, ash, beech, and hickory. It differs from all the other species of Tomoxia by having the pubescent markings on the elytra in longitudinal lines, as well as by other characters. The color varies from black to reddish brown.

M. L. Linell (1887: 171) considered this species to be the male of bidentata, basing his opinion upon certain collecting experiences. Nevertheless, even if it occupies the same tree as bidentata, it cannot be the same. C. A. Frost (1913: 126) has a very interesting article concerning this species and bidentata to prove that the two are distinct, and I have collected both sexes 
of the two forms and found them to belong, not only to different species, but to different genera.

The supposed type of this species, a female, in the Museum of Comparative Zoology, has been examined by me; it agrees with the above description.

Previous RECoRds.-Central states (Leconte) ; Ohio (Smith); Cincinnati, Ohio (Dury); southwestern Pennsylvania (Hamilton); Iowa City, Iowa (Wickham); Catskill Mountains (Nicolay); Staten Island, New York (Davis).

MATERIAL EXAmined.-Illinois: Willow Springs, June 24 (Gerhard, Wolcott, and Liljeblad); Rock Island (I.U.).

Indiana: Wolf Lake (Wolcott); East Gary, July 4 (Liljeblad).

Maine: Monmouth, June 27 (Frost).

Maryland: Plummers Island, July 10 (Barber and Schwarz, U.S.N.M.).

Michigan: Paw Paw Lake, June 22 (Liljeblad); Pentwater, July 4 (Liljeblad).

New Brunswick: Bathurst, July 9 (Knull).

New York : Brown's Mills (A.M.N.H.).

Ohio: Columbus, July 14 (Liljeblad).

\section{Tomoxia fascifera (Leconte)}

$$
\text { (Pl. III, Fig. 15) }
$$

Mordella fascifera Leconte, 1878, p. 427, Florida. Smith, 1882, pp. 81, 84.

DESCRIPTION.-Cuneiform, female a little broader than male; black, except labrum, antennae, palpi, anterior and middle legs, and posterior tibiae and tarsi, which are more or less dark testaceous; thorax with grayish pubescence, forming two upward-pointed, wedge-shaped markings, one each side of middle (these, however, a little variable in length), and in some specimens with grayish pubescence also on base and lateral margin; elytra with a broad band before middle and apical third with grayish pubescence.

Head broader than long, surface minutely aciculated and punctured, with sparse grayish pubescence; antennae short, not reaching base of thorax when head is extended, serrate, third to fifth segments nearly subequal in length, fifth much broader at apex; sixth to tenth each one-fourth shorter than fifth; last segment of maxillary palpi rather short, triangular; eyes large, moderately granulated and hairy, with a very small emargination behind antennae.

Pronotum nearly twice as broad as long, sides evenly rounded to apex, hind angles rounded, surface finely aciculated and with fine raised punctures.

Elytra narrower than thorax, surface reticulate and finely punctured; anteroir tarsal segments not dilated; posterior tibiae with the usual subapical ridge and with a fine, carinated ridge on outer dorsal edge; male has inner side of anterior tibiae with long hairs; anal style long and pointed. 
Length : to apices of elytra, $2.5 \mathrm{~mm}$; to tip of anal style, $3.5 \mathrm{~mm}$.

REMARKs.- This species in shape and color resembles several species of Mordella, but the pubescent markings are entirely different; the elytra have a median and apical gray band, and the thorax sometimes has the basal angles and sides somewhat grayish in addition to the two wedge-shaped grayish points. The above description agrees with the supposed type from Cedar Keys, Florida, in the Leconte collection, in the Museum of Comparative Zoology. It is rare in collections, and comparatively few specimens have been seen by the writer. It appears in May and June.

Previous records.-Cedar Keys, Florida (Leconte); Texas (Smith).

Material examined.-District of Columbia: Washington, June 29, July 20 (Hubbard and Schwarz, U.S.N.M.).

Texas : Columbus, June 2-3 (Hubbard and Schwarz, U.S.N.M.).

\section{Tomoxia undulata (Melsheimer)}

(Pl. III, Fig. 17)

Mordella undulata Melsheimer, 1846, p. 316, Pennsylvania. Leconte, 1862, p. 47. Smith, 1882 , pp. 81,84 .

Description.-Cuneiform, broader in female; black in male, brownish or purplish black in female, except antennae, palpi, and legs, which are more or less fusco-ferruginous, covered with gray or silvery white and black pubescence; head with short, coarse, grayish pubescence; antennae and palpi fusco-ferruginous; thorax with narrow lines or bands, a curved, semicircular band or line at apex, a line each side of middle extending upward to apical curved band, a similar line from basal angle upward, and a faint spot at apical angles, with grayish pubescence; elytra with tip and two arcuate bands with grayish or silvery pubescence; one near base divided, enclosing a large black spot on inner side toward scutellum and suture, and a smaller, triangular, black mark at humeri; other band usually broader and situated a little below middle, reaching suture and margin; anal style black with grayish pubescence at base ; underside black with grayish pubescence, denser on abdominal segments.

Head rather large, minutely punctured; antennae short, with segments five to ten subserrate; last segment of maxillary palpi scalene triangular; eyes reaching occiput, finely granulated and hairy.

Pronotum one-third broader than long, broader than elytra at base, finely punctured, its base in front of scutellum rounded; basal angles obtuse; scutellum triangular, broadly rounded at tip.

Elytra cuneate, reticulate, and finely punctured; apex rounded with fine but distinct margins; legs with anterior tarsi not dilated; middle tibiae as long as four tarsal segments combined on same pair of legs, posterior tibiae with usual subapical ridge and a carinated dorsal ridge along outer margin; 
first segment of posterior tarsi also with a similar carinated ridge half the length of segment; anal style longer in male than in female, pointed. Male more slender and anterior femora and tibiae more arcuate and with erect hairs on inner side.

Length : to apices of elytra, $2.5-3 \mathrm{~mm}$; t to tip of anal style, $3-3.5 \mathrm{~mm}$.

REMARKs.-This species somewhat resembles Tomoxia triloba (Say) in having the elytra banded, but it differs from that species by having the apex with gray pubescence, whereas in triloba the last band is situated one-fourth from apex. It apparently is very rare, as only a few specimens have appeared for examination. Melsheimer's supposed type, a female, in the Museum of Comparative Zoology, has been examined by me; it agrees with the above description. The species has been collected from July to August.

Previous ReCords.-Pennsylvania (Melsheimer); central and western states (Leconte); southwestern Pennsylvania (Hamilton); Cincinnati, Ohio (Dury).

Material examined.-Illinois: Algonquin, July 20 (Mason coll., I.U.). Kentucky: Frankfort (Soltau, U.S.N.M.).

Maine: Monmouth, July 29 (Frost); Paris, July 5 (Frost).

Maryland: Plummers Island, August 3 (Barber, U.S.N.M.) ; Cape John Br., July 29 (Barber, U.S.N.M.).

Massachusetts : Sherborn, August 23 (Frost).

New Hampshire: Rumney, July 23 (Darlington).

New York: New York City, July 4 (Soltau, U.S.N.M.).

Ohio : Cincinnati, August (Soltau, U.S.N.M.).

Pennsylvania: Black Gap (Gayton); Hummelstown, June 16 (Knull).

\section{Tomoxia serval (Say)}

(Pl. III, Fig 1)

Mordella serval Say, 1835, p. 191, Indiana; 1859, p. 662. Leconte, 1862, p. 47. Smith, 1882, pp. 81, 83. Blatchley, 1910, pp. 1312, 1313.

DESCRIPTION.-Cuneiform; black or dark reddish brown; head black with mottled cinereous pubescence; antennae rufous, apical segments darker; palpi rufous; prothorax black, with numerous spots of short yellowish or gray hairs, more evenly pubescent at apex; scutellum with yellowish or gray pubescence; elytra black, with numerous small spots of short yellowish hairs, a little larger spot near base, a dentated band behind middle, and a narrow band at apex; underside black or brownish with more or less cinereous hairs, denser at sides and on outer angle of abdominal segments; legs dark, posterior ones more rufous; anal style with cinereous pubescence near base.

Head densely punctured, aciculate; eyes reaching occiput, somewhat more coarsely granulated, hairy; antennae with first to fourth segments narrow; fifth to tenth serrate; fourth segment one-third shorter than third; 
fifth equal in length to third, much broader at apex; sixth to tenth subequal, each a little shorter than fifth; eleventh oval; last segment of maxillary palpi elongate-oval.

Pronotum nearly twice as board as long, finely punctured; sides slightly narrowing to apex; basal and apical angles obtuse; base broadly rounded in front of scutellum; scutellum triangular, broadly rounded at tip.

Elytra with surface reticulate, deeply punctured; apex rounded with fine but distinct margin; anterior tarsi with segments not or very slightly dilated; middle tibiae as long as first four tarsal segments of same pair of legs; posterior tibiae with a short subapical ridge near tip; and a narrow carinated dorsal ridge along outer margin; anal style short and pointed; no sexual difference has been discovered.

Length: to apices of elytra, $3 \mathrm{~mm}$.; to tip of anal style, $4 \mathrm{~mm}$.

REMARKs.-This species in color and pattern somewhat resembles $T$. borealis, but differs from it in the much narrower palpi and in the hairy eyes. It seems to be rather rare, since comparatively few specimens have been sent for examination. A slight variation occurs, however, as some specimens lack the larger basal spot on the elytra. It appears from May 1 to August 13.

Previous records.-Indiana (Say); New York, Long Island, Michigan, and Ohio (Smith); southwestern Pennsylvania (Hamilton); Cincinnati, Ohio (Dury) ; Ames, Iowa (Osborn) ; Iowa City, Iowa (Wickham) ; Putnam County, Indiana (Blatchley); Catskill Mountains, New York (Nicolay); Staten Island, New York (Davis).

Material examined.-Illinois: Fox Lake, August 2 (Frison, I.U.); Algonquin, July 12 (Nason coll., I.U.) ; Parker, June 12 (I.U.) ; Willow Springs (Liljeblad).

Iowa : McGregor (Wolcott).

Maine : Monmouth (Frost).

Manitoba: Aweme (Criddle).

Maryland : Plummers Island, June 15-23 (Barber, U.S.N.M.).

Massachusetts : Monterey, July 8 (Frost).

Michigan: Berrien County (Hubbell); Huron County (Biol. Survey, U.M.).

Missouri : St. Louis (Liljeblad).

New York: Ithaca (C.U.).

Ohio : Cincinnati (Knaus).

Pennsylvania: Easton (J. W. Green); Cresco and Carlisle Jc. (Knull).

\section{Tomoxia triloba (Say)}

(Pl. III, Fig. 19)

Anaspis triloba Say, 1824, pp. 139, 216, Missouri and Pennsylvania.

Mordella triloba Leconte, 1862, p. 47. Schwarz, 1878, p. 428. Smith, 1882, pp. 81, 84. Blatchley, 1910, p. 1314. 
Description.-Subcuneiform, broadest in female; black, except mouth parts, antennae, and legs which are fusco-testaceous; head with fine pubescence; thorax with irregular lines or marks of yellowish gray pubescence comprising a line on each side of middle from base to near apex, with sides more or less diffused; elytra with three such bands, one near base (broad and curved from near humeral angle to suture, enclosing a large scutellar black spot), one at middle (broad, reaching suture and side margin), and a similar band one-fourth from apex, with yellowish gray pubescence; these bands in some specimens may be connected with a narrow marginal line of similar pubescence; remainder of elytra and thorax above with black pubescence; underside with grayish pubescence; anal style rather thickly covered with silvery pubescence.

Head rather large, minutely punctured; eyes reaching occiput, finely granulated and hairy; antennae short, with segments five to ten serrate; last segment of maxillary palpi elongate securiform.

Pronotum nearly twice as broad as long, broader than elytra at base and more coarsely punctured; base in front of scutellum broadly rounded, basal angles obtuse; scutellum triangular, rounded at apex.

Elytra reticulate, coarsely punctured; apex rounded with distinct margin; anterior tarsi with fourth segment dilated; middle tibiae as long as all five tarsal segments of same pair of legs; posterior tibiae with usual subapical ridge, and a carinated dorsal ridge along outer margin, and a similar less pronounced carinated ridge on first segment of posterior tarsi; anal style long and slender, pointed.

Length : to apices of elytra, $3.5 \mathrm{~mm}$; t to tip of anal style, $4.5 \mathrm{~mm}$.

REMARKS.-This species apparently does not vary greatly and is readily recognized by its three grayish bands on the elytra. It may be confused with the following species, carinata, but that species has the bands more curved and in some specimens with the middle band broken. Leconte (1878:428) mentioned a variety from Florida with the bands narrower and the humeral region dull ferruginous. This, no doubt, is Tomoxia carinata Smith, since Nos. 4, 5, and 6, in Leconte's collection belong to that species. T. triloba seems to be nowhere common. It appears from May to late August.

Previous RECords.-Missouri and Pennsylvania (Say); central and western states (Leconte); southwestern Pennsylvania (Hamilton) ; Cincinnati, Ohio (Dury) ; Putnam and Posey counties, Indiana (Blatchley); New York (Nicolay).

Material examined.-Alabama : Langdale (H. H. Smith, U.S.N.M.).

Illinois : Edgebrook, June 14, August 27 (Liljeblad) ; Yorkville, July 23 (Gerhard) ; Henry, July 14 (Ramstadt) ; Algonquin, July 8, August 7 (I.S.N.H.S.) ; Springfield, June 27 (Hart, I.U.).

Kansas: Douglas County (Alexander). 
Maryland : Plummers Island, July 31 (Shannon, U.S.N.M.) ; Cabin John, July 23 (Knab, U.S.N.M.).

Michigan: Paw Paw Lake, July 8 (Liljeblad); Wakelee, July 27 (Bristol).

Missouri : Atherton, May 25 (Adams, K.U.).

New York: Ithaca, July 10 (C.U.).

Pennsylvania : Jeannette, June (Knull) ; Philadelphia and Buck County, June 20 (Liljeblad).

Vermont: Dummerston, July 14 (Frost).

Virginia : Rosslyn, August (H. H. Smith, U.S.N.M.).

\section{Tomoxia carinata (Smith)}

(Pl. III, Fig. 20)

Mordella carinata Smith, 1883, p. 3, Florida, Texas, and Louisiana.

DESCRIPTION.-Cuneiform; black, with bands and strealss of grayish or silvery pubescence; head with fine grayish pubescence; mouth parts and antennae rufous; thorax with base, sides, and an upward streak on each side of middle with grayish or silvery pubescence, forming three large black spots, all connected above middle; elytra with a rather large rufous humeral spot reaching downward one-third of length; also an oblique line downward from near scutellum which is almost connected with humeral spot, two small spots near middle, and a curved band near apex reaching from near suture to lateral margin, with grayish or silvery pubescence; rest of upper surface with dark pubescence; underside with gray pubescence denser at base of abdominal segments ; anterior legs more or less rufous ; posterior legs darker ; anal style with grayish pubescence from base to middle.

Head rather large, minutely punctured; eyes comparatively large, reaching occiput, very sparsely and minutely hairy and finely granulated; antennae short, reaching base of thorax, fifth to tenth segments serrate; third segment elongate, narrow, a little longer than fourth; last segment of maxillary palpi elongate, somewhat securiform.

Pronotum one-third broader than long, broader than elytra at base, evenly rounded to apex, and finely punctured; base in front of scutellum broadly rounded; basal angles broadly rounded; scutellum small, triangular, rounded at tip.

Elytra wedge-shaped, reticulate, and rather deeply punctured; apex broadly rounded with fine but distinct margin; legs with fourth segment of anterior tarsi dilated and bilobed; middle tibiae as long as all tarsal seginents of same pair of legs; posterior tibiae and first segment of posterior tarsi with a carinated ridge along dorsal edge; anal style long and pointed.

Length : to apices of elytra, $3.25 \mathrm{~mm}$; t to tip of anal style, $4.25 \mathrm{~mm}$.

REMARKs.-This species is easily recognized by the markings on the 
elytra. The ground color is somewhat variable and some specimens, especially from Texas, seem to be more reddish brown than are others from Louisiana and Florida. The grayish or silvery pubescent streak extending obliquely outward from the scutellum is not mentioned in the original description, but I find it present on all of the eleven specimens examined; also the spots at middle of the elytra are somewhat confluent in some specimens. Smith further stated that this species is closely allied to Glipodes on account of the dorsal carina, but while there is similarity in this respect, it is carried no further ; apparently Smith entirely overlooked the carina on the first segment of the posterior tarsi. One of the original specimens of this species in the Carnegie Museum (no. 2) has been examined by me and found to agree with the above description; this specimen is no doubt the one mentioned by Smith as Ulke's no. 2 and therefore may be selected as lectotype. The species has been collected from May to July.

Previous Records.-Florida, Texas, and Louisiana (Ulke); and Plano, Texas (Tucker).

Material examined.-Louisiana: Opelousas, May and June (Knaus coll.).

Texas: Brownsville (Wickham).

\section{Tomoxia discoidea (Melsheimer)}

(P1. III, Fig. 18)

Mordella discoidea Melsheimer, 1846, p. 315, Pennsylvania. Leconte, 1862, p. 47. Smith, 1882, pp. 81, 84. Blatchley, 1910, p. 1314.

Description.-Cuneiform, a little broader in female; black and fulvous; head fulvous with a large triangular black spot on disk; mandibles black; eyes black; antennae and palpi fulvous; thorax fulvous with a large triangular black spot reaching nearly to base in some specimens; elytra black with a somewhat oblique humeral vitta dull ferruginous, connected with a broad yellowish band a little before middle and another a little behind middle; apex, suture, and lateral margin below second band more or less yellowish; underside mostly black varied with fulvous; legs pale; anal style fulvous.

Head very minutely punctured; eyes rather prominent, reaching occiput, with setae-like hairs, rather coarsely granulated; antennae with first to fourth segments small; fifth to tenth broader, subserrate; third and fourth about equal in length; last segment of maxillary palpi boat-shaped or hammer-shaped in male, elongate, narrow, and securiform in female.

Pronotum two-fifths broader than long, evenly rounded to apex, finely punctured; base in front of scutellum rounded; basal angles obtuse; scutellum small, triangular, rounded at tip.

Elytra reticulate and finely punctured; apex rounded with fine but dis- 
tinct margin; anterior tarsi with fourth segment dilated; middle tibiae as long as all tarsal segments of same pair of legs; posterior tibiae and first segment of tarsi with a fine carinated ridge along dorsal outer edge; anal style long and slender.

Length : to apices of elytra, $3.25 \mathrm{~mm}$.; to tip of anal style, $4.25 \mathrm{~mm}$.

REMARKs.-This prettily marked species does not seem to be abundant. The markings vary a little, especially in the females, where the pale apical fascia is more or less obliterated. Leconte mentioned a variety with only two bands. I am unable to say whether or not this refers to a female, but it is more likely to be Smith's M. flaviventris, described from Florida. I was unable to locate the type in Melsheimer's collection. The insect appears from May 18 to July 25.

Previous Records.-Pennsylvania (Melsheimer); central, southern, and western states (Leconte) ; Long Island (Smith); southwestern Pennsylvania (Hamilton) ; Cincinnati, Ohio (Dury) ; Ames, Iowa, and Iowa City, Iowa (Osborn); Posey County, Indiana (Blatchley).

Material examined.-District of Columbia : Washington, August (Hubbard and Schwarz, U.S.N.M.).

Illinois: Willow Springs, June 8 (Liljeblad) ; Fox Lake, July 25 (Gerhard); Henry, July 15 (Ramstadt).

Indiana : Hessville (Wolcott).

Iowa: McGregor, July 14 (Wolcott and Liljeblad).

Maryland: Plummers Island, July 19 (Schwarz, U.S.N.M.) ; Cape John Br., July 29 (Barber, U.S.N.M.).

New Jersey : Phillipsburg (Green).

New York : New York City, July 4 (Soltau, U.S.N.M.).

Tennessee : Cumberland County, July 10 (Hubbell).

Virginia : Fredericksburg, June 15 (Richardson, U.S.N.M.).

West Virginia : Berkeley (Hubbard and Schwarz, U.S.N.M.).

\section{Tomoxia discoidea var. flaviventris (Smith)}

Mordella flaviventris Smith, 1883, p. 3, Texas and Florida.

\section{Description.-}

Form slender; anal style elongate; palpi and posterior tibiae as in the preceding: (sic), (carinata); first joint of posterior tarsi also with a subapical ridge and dorsal carina. Black; head and thorax yellow, the latter sometimes black on dise; elytra with a transverse spot before and another behind the middle, yellow, the posterior paler. Anterior and middle legs and posterior tarsi fulvous, as are also the last dorsal and ventral segment except the base of the anal style.

Length: $4 \mathrm{~mm}$.

\section{REMARKS.-}

Hab. Texas and Florida, 2 specimens. A very pretty species and very readily distinguished, not only by the tibial and tarsal ridges but also by the maculation on the upper side, which somewhat resembles that of discoidea. Mr. Ulke's numbers are 3 and 4 . (Smith) 
This species is, no doubt, only a color variety of the foregoing, T. discoidea, and can therefore be separated readily by the colored markings. I have examined certain specimens, especially from Texas, Louisiana, and Florida, that agree fully with Smith's description of flaviventris, but the color is not constant throughout the series. Some specimens from Columbus, Texas, and Enterprise, Florida, have the thorax pale and others have it dark, while some have and others lack the humeral dash on the elytra, which is present on discoidea. So far as specimens have been available for study they have shown that the male thorax is dark and the female thorax is pale. The antennae and palpi in both sexes, as well as the characters of the legs, are as in discoidea, except that there is no subapical ridge on the first segment of the posterior tarsus (as was described by Smith, no doubt in error), but only the usual apical ridge. The differences in color from true discoidea are so great that I hesitate to place it in synonymy.

The above description agrees with the two specimens in Ulke's collection, numbered 3 and 4, from which the description was made. As no type was selected by the describer, I propose to designate no. 3 from Texas (now in the United States National Museum) as lectotype and no. 4 from Florida (in the Carnegie Museum) as paratype, both being females.

\section{MORDELLISTENA COSTA}

Mordellistena Costa, 1854, p. 16.

Description.-The principal characters of this genus are as follows: posterior tibiae with a short, transverse subapical ridge and one to six more or less oblique ridges on outer face; first to third segments of posterior tarsi with similar ridges; scutellum usually triangular; anal style long; antennae more or less serrate or filiform; last segment of maxillary palpi variable in form, usually more or less triangular but in some species oval, in others boatshaped, especially in male sex.

Remarks.-This genus of Mordellidae contains the greatest number of species, many of which are attractively colored. They are usually found, in the adult stage, on flowers of many species, some on leaves and a few on fungi. The sexes are rather difficult to separate unless the genitalia are extruded, but a good character in many species is in the shape of the terminal segment of the maxillary palpi, which may be boat-shaped or hammer-shaped in the male and oval or elongate in the female. In some species the inner angle of the maxillary palpi is more sharply defined in the male and rounded in the female.

The grouping of the species has been based on the number and position of the ridges on the posterior legs, since these are more reliable than are the antennae or other characters. The ridges may vary a little in some species, but if one or more small, upper, rudimentary ridges are found on specimens 
under examination the observer must be sure that they are present on both legs and are not simply one or two spinules or setae which cannot be considered a full ridge. The characters of color and palpi should prove useful in identifying the species.

\section{KEY TO SPECIES}

Posterior tibiae with one ridge on outer face …............................................................................................ 2

Posterior tibiae with two or more ridges on outer face ........................................................................... 5

2. First segment of posterior tarsi with one ridge ……........................................................................... 3

First segment of posterior tarsi with two ridges ........................................................................ 4

3. Head orange; thorax orange or with a dark cloud at base; elytra black or dark brown with two yellow bands; Pl. IV, Fig. 3 ..................................................... (p. 76) bicinctella

Head black; clypeus, base of antennae, and palpi testaceous; thorax black, basal angles and a line at base yellowish; elytra black; last segment of maxillary palpi hammer-shaped or boat-shaped; Pl. IV, Fig. 1 .............................................(p. 77) frosti

Black; elytra with an oblong, dull yellow humeral spot .............................. (p. 78) confusa

4. Tibial ridge entirely crossing outer face; black elytra with an orange yellow vitta; Pl. IV, Fig. 4

(p. 78) tarsalis

Tibial ridge short; first segment of posterior tarsi with two and second segment with one ridge; head and thorax shining black; elytra dark, with grayish pubescence

(p. 78$)$ viridescens

5. Posterior tibiae with two ridges on outer face

Posterior tibiae with three or more ridges ....................................................................................... 38

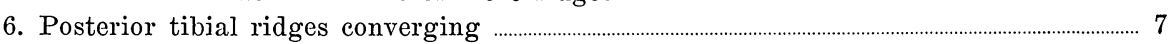

Posterior tibial ridges parallel, equal in length or nearly so ................................................... 11

Posterior tibial ridges with upper one extending nearly across the outer face ........... 30

7. First segment of posterior tarsi with two ridges and second with one ridge ..................... 8

First segment of posterior tarsi with three ridges and second with one ridge ........... 9

First segment of posterior tarsi with three ridges and second with two .................... 10

8. Entirely yellow testaceous ............................................................................................... (p. 80) lutea

9. Uniformly brownish or reddish yellow, except eyes, mandibles, tip of middle and posterior tibiae and tip of tarsal segments, which are black; last segment of maxillary palpi elongate, somewhat boat-shaped; Pl. IV, Fig. 2 ............. (p. 81) arida

10. Head and thorax dark brown, antennae, palpi, and elytra fusco-ferruginous; last segment of maxillary palpi elongate ……………............................................... (p. 82) knausi

11. First segment of posterior tarsi with two ridges and second with one ridge ................ 12

First segment of posterior tarsi with two ridges and second with two ......................... 19

Posterior tarsi with more or different ridges ..................................................................................... 20

12. Elytra with two colors in bands, spots, or lines .......................................................................... 13

Elytra uniform in color or nearly so .................................................................................................... 16

13. Elytra more or less banded, or with a humeral spot ..................................................................... 14

Elytra with suture more or less black ............................................................................................ 15

14. Elytra with three black and two yellow bands, basal like three connected spots; head, antennae, and palpi testaceous; thorax entirely testaceous in male, in female with a dark apical spot; Pl. IV, Fig. 9

(p. 83) trifasciata

Elytra with three separated spots at base, a spot on each elytron at middle, and a band one-fourth from tip; head and thorax yellow, latter dark on disk; Pl. IV, Fig. 10 (p. 86) sexnotata

Elytra black with reddish yellow humeral spot; antennae at base and palpi reddish yellow; Pl. IV, Fig. 11 (p. 87) scapularis 
15. Elytra testaceous, with suture and lateral margin black; head and thorax testaceous, latter with a black spot on disk; Pl. IV, Fig. 12 (p. 89) limbalis

Upper surface yellow; apical margin of thorax, suture, broad median band, and apex of elytra dark fuscous (p. 90) elegantula

Reddish yellow; suture and lateral margin black; abdomen nearly black; last segment of maxillary palpi scalene; Pl. IV, Fig. 13 (p. 91) dimidiata

16. Elytra entirely black 17

Elytra entirely brownish yellow, luteous or flavo-testaceous 18

17. Black, except the antennae in female which are dusky brown; last segment of maxillary palpi scalene; antennae not longer than head; Pl. IV, Fig. 5

(p. 92) vilis

Black, except basal segments of antennae which are dark rufous; last segment of maxillary palpi rounded on inner angle; antennae longer than head and thorax; Pl. IV, Fig. 6

(p. 93) pauxilla

Black, with front part of head, mouth parts, antennae, palpi, front and middle legs, hind tibiae and tarsi, and apex of anal style yellowish

(p. 94) paradisa

Head and thorax testaceous yellow; elytra fuscous with humeri and apical margin reddish yellow; abdomen, sternum, hind coxae, and femora blackish.

(p. 95) fulvicollis

18. Entirely luteous; last segment of maxillary palpi elongate securiform; Pl. IV, Fig. 7

(p. 96) vapida

Flavo-testaceous; head dark; undersurface black

(p. 79) wenzeli

Head and thorax black; mouth, antennae, palpi, and anterior legs dusky; elytra yellowish brown, dusky toward apical half; last segment of maxillary palpi elongate securiform; Pl. IV, Fig. 8

(p. 97) intermixta

19. Black; mouth, front, two small spots on apical margin of thorax, and anterior feet reddish yellow

(p. 97) bipustulata

Fulvo-piceous; head slightly paler; tibial ridges longer than usual........(p. 97) atriceps

Body black; elytra golden yellow; suture and lateral margin narrowly fuscous

(p. 98 ) pratensis

Entirely yellowish testaceous; last segment of maxillary palpi broadly triangular

(p. 98) errans

20. First segment of posterior tarsi with three ridges and second with one ridge ........... 21

First segment of posterior tarsi with three ridges and second with two ................. 22

First segment of posterior tarsi with four ridges and second with three ..................... 29

21. Piceous, with brown pubescence; elytra piceo-testaceous; last segment of maxillary palpi elongate, scalene

(p. 99) picipennis

Piceous, elytra rufous, suture and margin blackish; last segment of maxillary palpi short, scalene

(p. 99) pallipes

Head, thorax, antennae and palpi dark reddish brown; elytra black; last segment of maxillary palpi scalene; Pl. IV, Fig. 14 (p. 101) nebulosa

22. Elytra with a humeral spot

23

Elytra more or less striped, or with a vitta ........................................................................................... 24

Elytra without markings ..................................................................................................................... 25

23. Black with yellowish markings; head testaceous or nearly so; antennae and palpi testaceous; thorax partly black or testaceous; elytra black with long, triangular humeral spot; suture from near base almost to apex yellowish testaceous, this line broader one-third from apex, forming an obsolete band; Pl. IV, Fig. 15

(p. 101) ornata

Black; head and humeral spot of elytra reddish yellow; last segment of maxillary palpi scalene

(p. 104) militaris 
24. Head flavo-testaceous, dark at middle; thorax flavo-testaceous, dark on basal half; elytra black, with a broad vitta from base to near apex; last segment of maxillary scalene; Pl. IV, Fig. 16

(p. 104) argenteola

Head black, mouth parts and four basal segments of antennae fusco-ferruginous; thorax black; elytra black with two sericeous cinereous stripes; last segment of maxillary palpi securiform; Pl. IV, Fig. 17 ........................................ (p. 106) syntaenia

Head ferrugineous, vertex black; thorax black with rufous spot at each apical angle; elytra rufous with suture and lateral margin narrowly black; last segment of maxillary palpi elongate triangular; Pl. IV, Fig. 18 ................................ (p. 107) egregia

25. Above bicolored ............................................................................................................................................ 26

Above uniformly black or nearly so ................................................................................................. 27

Above uniformly pale or nearly so ...................................................................................................... 28

26. Head and thorax reddish yellow, sometimes with a faint cloud at base; elytra black, with pubescence dense, shining silvery, metallic; last segment of maxillary palpi scalene; Pl. IV, Fig. 19 (p. 108) comata

Black; thorax ferruginous, with linear dorsal cloud in male, with basal half more or less dark in female; Pl. IV, Fig. 20 ........................................................... (p. 109) cervicalis

Rufo-piceous; elytra darker with a large, indistinct, paler basal spot

(p. 111) indistincta

27. Black, except mentum, palpi, and two basal segments of antennae; antennae reaching to base of thorax; last segment of maxillary palpi scalene; Pl. IV, Fig. 21

(p. 111) aspersa

Black, front of head rufo-testaceous; four basal segments of antennae, palpi, anterior legs, and femora and tibiae of middle legs testaceous; antennae reaching to base of thorax; last segment of maxillary palpi elongate triangular........ (p. 113) rubrifascia

Head black, front rufous; thorax black, more or less rufous in front; elytra black, with pubescence reddish brown; antennae longer than head and thorax; last segment of maxillary palpi broadly triangular; Pl. IV, Fig. 22..... (p. 113) rufilabris

Similar to rufilabris, but antennae do not reach base of thorax; last segment of maxillary palpi elongate securiform; Pl. IV, Fig. 23 ................... (p. 114) rubrilabris

Entirely black; antennae reaching to near base of thorax; last segment of maxillary palpi scalene; Pl. IV, Fig. 24 (p. 115) pullata

Entirely black; head unusually large; last segment of maxillary palpi elongate, somewhat cultriform, or nearly an isosceles triangle, second segment very broad in male

(p. 116) nigella

28. Pale yellowish brown, apical half of elytra more dusky; last segment of maxillary palpi scalene in male, elongate securiform in female ................................... (p. 117) tosta

Pale yellowish testaceous; abdcmen infuscate except at apex; last segment of maxillary palpi strongly dilated …………..................................................... (p. 118) pallens

29. Fulvous yellow (p. 118) inornata

30. First segment of posterior tarsi with two ridges and second with one ridge ........... 31

First segment of posterior tarsi with three ridges and second with two .......................... 32

First segment of posterior tarsi with four ridges and second with two ......................... 37

31. Head black, front reddish yellow; thorax black; elytra with two yellowish bands; last segment of maxillary palpi elongate securiform; Pl. V, Fig. 1 (p. 119) minuta

Nearly black, except palpi, anterior legs, and basal segments of antennae which are reddish testaceous; last segment of maxillary palpi scalene; Pl. V, Fig. 2

(p. 120) picilabris

Entirely black; antennae short, reaching to base of thorax, second segment largest; last segment of maxillary palpi elongate securiform; Pl. V, Fig. 3

(p. 121) minutalis 
32. Elytra with more or less distinct markings ...................................................................................... 33

Elytra without distinct markings ................................................................................................................ 34

33. Black; elytra with three bands of grayish pubescence, one at base, one at middle, and one one-fourth from apex; last segment of maxillary palpi scalene; Pl. V, Fig. 4

(p. 122) infima

The male with head, thorax, antennae, palpi, and legs yellowish; female with head (except in front of antennae) and thorax black; elytra yellowish with base, suture, apex, and a large oblong marginal or nearly submarginal spot at middle, black; Pl. V, Figs. 5 and 6 (p. 123) andreae

Head, thorax, antennae, and palpi yellowish or more or less ferruginous; elytra ferruginous with suture and margin narrowly black; underside nearly black; Pl. V, Figs. 7 and 8 ...................................................................(p. 125) andreae var. ancilla

Head, thorax, antennae, and palpi yellowish or somewhat ferruginous; elytra ferruginous, with suture and margin very narrowly black; Pl. V, Fig. 9

(p. 126) andreae var. ustulata

Head, thorax, antennae, palpi, anterior legs, middle femora, and humeral spot of elytra ferruginous; remainder black; Pl. V, Fig. 10 ........................... (p. 127) semiusta

Head testaceous; thorax black with small ferruginous spot at apical angle; elytra black with an oblique, oval testaceous spot and one small spot one-third from tip

(p. 128) quadrinotata

Black; elytra with numerous cinereous spots; Pl. V, Fig. 11 ............. (p. 129) guttulata

34. Upper surface black or nearly so ................................................................................................... 35

Upper surface more or less ferruginous, fulvous, or yellowish .................................................. 36

35. Black; head, apical margin of thorax, palpi, anterior legs, middle femora, and last abdominal segment ferruginous ........................................................................... (p. 130) impatiens

Elongate, piceous, with dense, bright, sage green pubescence ............. (p. 130) delicatula

Nearly black. base of antennae and labrum rufo-testaceous; last segment of maxillary palpi triangular, inner side much shorter than apical; Pl. V, Fig. 12

(p. 131) nigricans

Almost entirely black; antennae reaching below thorax; last segment of maxillary palpi scalene; Pl. V, Fig. 13

(p. 133) parva

Black; antennae, palpi, anterior legs, middle tibiae and tarsi, and posterior tarsi ferruginous; antennae reaching to base of thorax ............................... (p. 133) blatchleyi

36. Fusco-ferruginous; antennae, apical segment of maxillary palpi in female black; last segment of maxillary palpi elongate scalene; Pl. V, Fig. 14 ........... (p. 134) subfucus

Fusco-ferruginous; elytra black, with pubescence dark ............... (p. 135) ferruginoides

Uniform dull brownish yellow (p. 135) testacea

Entirely fulvous, covered with silky yellowish pubescence; abdominal segments dark; Pl. V, Fig. 15 . ...................................................................................... (p. 135) wickhami

Entirely pale yellow or fulvous, with long, coarse, yellow hairs; basal lobe of thorax emarginate at middle (p. 136) crinita

Black; head ferruginous; antennae, palpi, anterior legs, middle tibiae and tarsi testaceous; Pl. V, Fig. 16 (p. 137) ruficeps

Ferruginous; sides of pectus and elytra darker ................................................ (p. 138) nubila

Piceo-testaceous, sometimes more or less rufous, densely covered with silvery pubescence; last segment of maxillary palpi elongate scalene ........ (p. 139) splendens

37. Almost entirely black; last segment of maxillary palpi triangular, inner side shorter than apical; Pl. V, Fig. 17 (p. 140) floridensis

Ferruginous; elytra with lateral margin and suture black ............................... (p. 141) rufa

38. Posterior tibiae with three oblique ridges on outer face ...................................................... 39

Posterior tibiae with four or more ridges 
39. Ridges parallel, about equal in length ...................................................................................... 40

Ridges parallel, second extending almost across outer face of tibiae ................................. 61

40. First segment of posterior tarsi with three ridges, and second with one or two ridges ............................................................................................................................................................... 41

First segment of posterior tarsi with three ridges and second with two .................... 42

Posterior tarsi with more or different ridges ..................................................................................... 51

41. Head and thorax black; antennae and palpi rufo-testaceous; elytra nearly black with an oblique humeral vitta; female with elytra more rufous .......... (p. 142) smithi

42. Upper surface entirely black or nearly so ................................................................................................ 43

Upper surface not entirely black ..................................................................................................... 46

43. Elytra without spots or markings ............................................................................................................. 44

Elytra with spots or longitudinal lines ........................................................................................ 45

44. Black, pubescence brownish gray ………….............................................................. (p. 142) morula

Black, with reddish brown and gray pubescence, base of thorax at middle with a V-shaped notch ; Pl. V. Fig. 21 ........................................................ (p. 143) nunenmacheri

45. Almost entirely black; elytra sprinkled with numerous cinereous spots; last segment of maxillary palpi elongate cultriform; Pl. V, Fig. 22

(p. 144) pustulata

Nearly black; elytral pubescence formed in brownish gray longitudinal lines; Pl. V, Fig. 23

(p. 146) convicta

Black, pubescence gray with sparse fuscous hairs which on elytra form longitudinal lines, giving a faint vittate appearance; last segment of maxillary palpi moderately dilated, inner and apical sides equal

(p. 148) suspecta

46. Elytra in bands, spots, fasciae, longitudinal lines, or vittae ……………………................. 47 Elytra uniform in color ........................................................................................................................ 48

47. Body black; elytra fuscous with pale cinereous pubescence, and with a narrow median band and a broader subapical fascia

(p. 148) hirticula

Black; mouth and anterior feet piceous; thorax with three black clouds; elytra with an undulated band before middle and a large oblong spot near tip fuscous

(p. 149) scalaris

Head and thorax black; elytra rufous, a basal spot, an undulated band behind middle (which reaches suture and side margin), tip and suture with silky yellowish pubescence; Pl. V, Fig. 24 (p. 149) discolor

Black; thorax black with three well-defined spots; elytra with humeral angle more or less ferruginous; a sutural line, a curved band from humeri to suture, a transverse band behind middle, and tip cinereous; Pl. V, Fig. 26 ........... (p. 150) pubescens

Head black; thorax black, with basal side margin more or less ferruginous; elytra reddish brown with yellowish pubeseence in a short band from humeri downward, two elongated marks near suture, two similar marks at lateral margin, and tip; these spots or bands sometimes connected; Pl. V, Fig. 25 ............... (p. 152) bihamata

Elytra black with cinereous markings; a narrow sutural line, an oblique basal band from humeri to suture, a transverse band behind middle, and a narrow submarginal line connecting basal and middle band and apex; Pl. V, Fig. 27

(p. 154) hebraica

Fusco-luteous; elytra darker brown near base; an oblique band from humeri to suture, a large oblique spot at middle, a broad spot at apex, and a narrow sutural line with silky yellowish pubescence; Pl. V, Fig. 28 (p. 155) liturata

Head ferruginous; thorax ferruginous with a dark streak at middle; elytra black with a short rufous streak at middle of base in male; this rufous streak is extended as a vitta to near apex in female; Pl. V, Figs. 29 and 30 (p. 157) pulchra

Same as pulchra but without any trace of a streak or vitta on elytra in either sex (p. 157) pulchra var. proxima 
48. Elytra black or fuseous ................................................................................................................................... 49

Elytra ferruginous or reddish brown ........................................................................................... 50

49. Head and thorax ferruginous with yellowish gray pubescence; elytra fuscous brown, densely covered with yellowish brown pubescence, silvery gray in female; anterior legs pale

(p. 158) caliginosa

Head dark brown, antennae and palpi fuscous; thorax, elytra, and underside black

(p. 159) tantula

Head and thorax testaceous; elytra fuscous with base, humeri, and sides to near middle testaceous .......................................................................................................... (p. 159) palmi

50. Ferruginous with yellowish white pubescence; last segment of maxillary palpi elongate scalene

(p. 160) blandula

Fusco-ferruginous or dark reddish brown; last segment of maxillary palpi elongate triangular; ridges very long and more oblique than usual ............... (p. 161) ambusta

51. First segment of posterior tarsi with three ridges, second with two, and third with one ridge

Posterior tarsi with more or different ridges

52

52. Head and thorax ferruginous; elytra black, with base, humeral angle, suture, and sometimes sides more or less ferruginous or with golden pubescence; Pl. VI, Fig. 1

(p. 162) fuscipennis

Head reddish brown; thorax dark reddish brown with blue-green luster; elytra eastaneous with yellowish pubescence; legs testaceous ................................. (p. 164) badia

53. First segment of posterior tarsi with three ridges, second with two, and third with two

First segment of posterior tarsi with four ridges and second with two .............................. 55

Posterior tarsi with more or different ridges ................................................................................. 58

54. Ferruginous; elytra black, pubescence fine and dark ............................ (p. 165) singularis

55. Elytra without bands or spots ............................................................................................................... 56

Elytra with bands or spots ....................................................................................................................... 57

56. Black, covered with brown sericeous pubescence; Pl. VI, Fig. 8 ........... (p. 165) unicolor

Black; pubescence fine and dark; mouth and anterior part of thorax ferruginous.

(p. 167) marginalis

Black with head and thorax partly rufo-testaceous; thorax with basal half black, outline sharply defined, bisinuate; elytra black with dense silky pubescence; Pl.

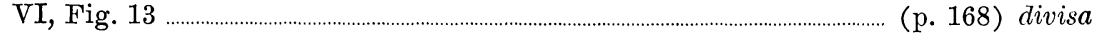

Black, very densely covered with sericeous cinereous pubescence; base of antennae and front and middle legs more or less pale; last segment of maxillary palpi twice as long as wide

(p. 169) sericans

57. Head and thorax fusco-ferruginous; elytra fuscous, humeral angle fulvous; a sutural line connected with a basal curved band extended downward to near suture; a somewhat interrupted band below middle, and a band one-fourth from apex, connected with sutural line; Pl. VI, Fig. 2

(p. 170) leporina

Ferruginous; elytra black, with a small, indistinct humeral spot fer'ruginous; abdomen blackish, anterior margin of ventral segments rufous ........................ (p. 172) schauppi

58. First segment of posterior tarsi with four ridges, second with two and third with two

First segment of posterior tarsi with four ridges and second with three

59. Black with silky brownish pubescence; elytra with pubescence forming a sutural line; Pl. VI, Fig. 11 (p. 172) vera

Head dark; prothorax yellowish with large black spot; elytra dark ferruginous, suture narrowly black (p. 173) lodingi 
60. Entirely black

(p. 174) aequalis

Body and elytra black; head and thorax rufous

(p. 175) conformis

Black with bluish green luster; elytra with golden yellow pubescence along suture and a rather broad vitta from near base to middle; last segment of maxillary palpi securiform; Pl. VI, Fig. 5

(p. 175) incommunis

61. Entirely black except palpi, basal segments of antennae, and anterior femora which are fusco-ferruginous; last segment of maxillary palpi nearly an isosceles triangle; Pl. VI, Fig. 7 (p. 176) husseyi

62. Posterior tibiae with four ridges on outer face 63

Posterior tibiae with five or more ridges on outer face

63. First segment of posterior tarsi with three ridges and second with two .

First segment of posterior tarsi with four ridges and second with two

Posterior tarsi with more or different ridges

64. Fuscous; pubescence dull golden

65. Rufo-piceous; mouth, antennae, legs and elytra paler (p. 177) fuscata

Head and thorax reddish brown; elytra dark brown with golden pubescence forming an oblique band from humeri to near suture, a marginal line, an abbreviated band at middle, a sutural streak, an apical blotch connected with marginal line, and several small spots situated between bands; Pl. VI, Fig. 3 (p. 178) masoni

Nearly black, except mouth, basal segments of antennae, and anterior and middle femora, which are ferruginous in male and black in female; last segment of maxillary palpi securiform; Pl. VI, Fig. 10

(p. 179) aethiops

66. First segment of posterior tarsi with four ridges and second with three ......................... 67

First segment of posterior tarsi with five ridges and second with three .......................... 68

Posterior tarsi with ridges on three segments ............................................................................... 69

67. Black, with sericeous pubescence; head, thorax and anterior legs ferruginous.

(p. 180) texana

68. Slender; pale reddish brown; anterior and middle legs dull reddish yellow.

(p. 181) hoosieri

Nearly black, except basal half of anterior femora; elytra with narrow sutural line; last segment of maxillary palpi nearly cultriform

(p. 181) suturella

69. First segment of posterior tarsi with four ridges, second with two, and third with one ridge

First segment of posterior tarsi with four ridges, second with three, and third with three

Posterior tarsi with more or different ridges .................................................................................. 72

70. Rufous; elytra black having humeral angle, basal margin, and suture with goldeu yellow pubescence; last segment of maxillary palpi short, securiform; PI. VI, Fig. 4 (p. 182) gigas

71. Slender, dark fuscous; four basal segments of antennae and anterior and middle feet piceous

(p. 183) fusco-atra

72. First segment of posterior tarsi with five ridges, second with three, and third with two ridges 73

First segment of posterior tarsi with five ridges, second with four, and third with three ridges

73. Black; pubescence of head and thorax brownish, of elytra black with suture narrowly gray; abdomen rufous varied with black (p. 183) rufiventris

74. Very slender; entirely black; pubescence fine and dark (p. 184) angusta

75. First segment of posterior tarsi with four ridges and second with one ridge ................ 76 First segment of posterior tarsi with five ridges and second with two 77 
76. Head rufous; thorax in male rufous or rufo-testaceous with a large dark spot on anterior disk; female black; elytra black with a somewhat oblique vitta from base nearly to apex, golden pubescent; Pl. VI, Fig. 6 (p. 184) attenuata

77. Entirely black with dense silvery gray pubescence, which, on elytra, is more or less mottled; Pl. VI, Fig. 9

(p. 186) aemula

\section{Mordellistena bicinctella Leconte}

(Pl. IV, Fig. 3)

Mordellistena bicinctella Leconte, 1862, p. 48, southern states. Smith, 1882, pp. 85, 90 ; 1883, p. 3. Champion, 1891, p. 346. Blatehley, 1910, p. 1316.

DESCRIPTION.-Posterior tibiae with one short ridge, subapical not included; first segment of posterior tarsi with one ridge, very rarely with the rudiment of a second ridge.

Form narrow, sides parallel; head, antennae, and palpi orange colored; thorax orange but sometimes with a dark cloud at base; elytra black or dark brown, covered with long yellowish pubescence and with two yellow bands, one near base interrupted at suture, other one-fourth from apex. Black band nearest base always has lower edge in a nearly straight line crossing the two elytra.

Head moderate in size, very minutely punctured; antennae short, filiform, very little longer than head; first and second segments large; third and fourth very small, each a little shorter than fifth; sixth to tenth subequal in length, but each a little broader than fifth ; last segment of maxillary palpi somewhat boat-shaped in male and scalene in female; eyes nearly oval, finely granulated.

Prothorax about one-fourth broader than long, minutely punctured; basal angles obtuse.

Elytra short, subparallel to near apex ; anal style rather long and pointed.

Length : to apices of elytra, $1.5-2.5 \mathrm{~mm}$.

REMARKS.-This species has a rather wide range. It is variable in color, as the thorax may be either black or reddish yellow or with a cloud at base. The type or first specimen in the Leconte collection, in the Museum of Comparative Zoology, is from Texas, and has the thorax black; no. 2, without any locality label, has a light thorax; no. 3, from North Carolina, has. a dark thorax; nos. 5 and 6 , from Louisiana, have a black shading and have the bands on the elytra sometimes more reddish than yellow. The species is very rare in collections, but several specimens have been examined by me, all of which agree with the type.

Previous Records.-Southern states (Leconte); Texas and District of Columbia (Smith); Steuben and Marshall counties, Indiana, June 11 to July 6 (Blatchley); and Cincinnati, Ohio (Dury).

Material EXAMined.-District of Columbia: Washington, June 13 (Hubbard and Schwarz, U.S.N.M.). 
Illinois : Mount Carmel, May 28 and Quincy, July 2 (I.U.).

Manitoba: Aweme, July 3 (Criddle).

Michigan : Milford, June 20 (Hubbell, U.M.).

Pennsylvania : Philadelphia Neck, July 10 (Hubbell, U.M.).

Texas: Brownsville, July (Wickham).

\section{Mordellistena frosti Liljeblad}

(P1. IV, Fig. 1)

Mordellistena frosti Liljeblad, 1918, p. 156, Maine.

Description.-Posterior tibiae with one short, strongly marked ridge, subapical not included; first segment of posterior tarsi with one small ridge near tip.

Linear; head shiny black, with clypeus and front around antennae, three basal segments of antennae, and palpi testaceous; prothorax black or brownish black, with basal angles and a narrow line at base yellowish, covered with long, silky yellowish pubescence; elytra black or brownish black, covered with fine, reddish brown, iridescent pubescence; undersurface black; anterior legs testaceous; middle and posterior legs fuscous.

Head rather large, finely punctured; antennae short, filiform, reaching to base of thorax; fifth to tenth segments uniform in width; third segment shortest; fourth to tenth subequal in length, each very little longer than third ; last segment of maxillary palpi hammer-shaped in male, elongate oval in female; eyes coarsely granulated, hairy.

Prothorax one-third broader than long, finely punctured, more coarsely at base; basal angles rather broadly rounded; basal lobe at middle in front of scutellum broadly rounded.

Elytra nearly parallel to near apex; surface reticulate and somewhat coarsely punctured; anal style short and very slender.

Length : to apices of elytra, $3.5 \mathrm{~mm}$; t to tip of anal style, $4.5 \mathrm{~mm}$.

REMARKS.-This species apparently is rather rare. In the original description it was said to be closely allied to Mordellistena confusa Blatchley, but the similarity exists only with respect to the ridges, and the species does not resemble any other in the markings of the thorax. There is a slight variation in the color of the antennae, the type having the apical angles of each segment yellowish, whereas the antennae are unicolorous in the paratype.

Previous Records.-Aziscoos Lake, Maine (Liljeblad).

Material examined.-Manitoba: Aweme, July 3 (Criddle).

New Brunswick: Bathurst, June 2 (Knull).

New Hampshire: Tamworth, June 25 to July 23 (Darlington). 


\section{Mordellistena confusa Blatchley}

Mordellistena confusa Blatchley, 1910, p. 1316, Indiana.

\section{Description.-}

Hind tibiae and first joint of hind tarsi each with a single short oblique ridge near tip.

Very slender, parallel. Black, sparsely clothed with brownish pubescence; elytra with an oblong, dull yellow humeral spot; labrum, palpi, tarsi and abdominal process dull brownish yellow.

Length: $2.5 \mathrm{~mm}$.

REMARKS.-

Martin County, rare. May 16. Resembles biplagiata in color, but much more slender and with but one ridge on the tibiae and first tarsal. (Blatchley)

I have not seen the type.

\section{Mordellistena tarsalis Smith \\ (Pl. IV, Fig. 4)}

Mordellistena tarsalis Smith, 1883, p. 80, Texas.

\section{DESCRIPTION.-}

Posterior tibiae with a single strongly marked oblique ridge, entirely crossing the outer face, subapical strongly marked; first joint of posterior tarsi with two oblique ridges.

Form stout, cuneate; black; mouth, margin of thorax and a broad vitta on elytra orange yellow; legs except posterior tibia pale.

Length: $1.5 \mathrm{~mm}$. (Smith)

ReMarks.- "A single specimen in my collection" (Smith).

I have not seen any specimen that agrees with it. A single specimen under the above name is in the United States National Museum, labeled as “Type No: 1233 from Columbus, Texas 3.6." This, however, does not agree with the description, as the posterior tibiae have the usual subapical ridge and, in addition, bear a longitudinal ridge on the outer dorsal margin. There is also a similar longitudinal ridge partly broken on the first segment of posterior tarsi. If the above "Type No: 1233"' is the original type of $M$. tarsalis Smith, then the species is wrongly described and must belong to the genus Tomoxia. The elytra are more yellow or brownish yellow than black; they have a humeral spot, an elongate marginal spot at middle, the suture, the scutellar area, and one-fourth of the apex black. The accompanying outline drawing of the elytra of this species was kindly furnished by Edward A. Chapin.

\section{Mordellistena viridescens, new species}

Trpe.-From Baldwin, Florida. A male, collected on June 1 by J. B. Smith; in the collection of the United States National Museum.

Aliotype.-A female, same data as type.

Paratypes.-Three, same data as type; one, Tampa, Florida, June 10; paratypes in the Museum of Zoology, University of Michigan. 
Description.-Posterior tibiae with one oblique ridge and a rudiment of a second in some specimens, subapical not included; first segment of posterior tarsi with two ridges, second with one ridge.

Narrow, cuneate; shining black; head and pronotum sparsely covered with brownish pubescence; antennae at base, palpi, and anterior legs of a dark brown color; elytra black, very densely covered with a heavy grayish pubescence that has a greenish blue iridescent luster; underside a little darker than elytra.

Head comparatively large, with surface very minutely aciculated; antemnae filiform or nearly so, reaching to base of thorax when head is extended, rather densely covered with hair; third and fourth segments subequal; fifth to tenth subequal in length, each one-fourth longer than fourth; last segment of maxillary palpi broadly triangular, apical side a little longer than inner; eyes margined behind, moderately granulated, not emarginated.

Pronotum one-fourth broader than long; basal angles obtusely rounded, surface finely aciculated, with somewhat raised punctures.

Elytra rather strongly tapering to apex, surface like pronotum. Anal style long and very pointed.

Length : to apices of elytra, $2 \mathrm{~mm}$.; to tip of anal style, $2.75 \mathrm{~mm}$.

REMARKs.-This species, which does not resemble any other Mordellistena, is readily recognized by its narrow form and by its shining black head and thorax, which, with their gray and greenish blue iridescent luster, are in contrast to the dark but heavily pubescent elytra.

\section{Mordellistena wenzeli, new species}

Type.-From Tybee Island, Georgia. A male, collected June 27-30, by H. W. Wenzel; in the collection of Ohio State University.

PARATYPes.-Two specimens, both males, same data as type; paratype in the Museum of Zoology, University of Michigan (Liljeblad coll.).

Description.-Posterior tibiae with two short, slightly oblique ridges, subapical not included; first segment of posterior tarsi with two ridges and second with one ridge.

Slightly cuneiform, nearly parallel; upper surface flavo-testaceous, head a little darker; undersurface nearly black; antennae, palpi, and anterior legs pale, posterior legs fuscous; upper surface with rather coarse, shining yellow pubescence; scutellum nearly black.

Head comparatively large, surface minutely aciculated; antennae short, filiform, reaching to middle of thorax ; first and second segments very robust, twice as thick as third; third and fourth about equal in length, narrow at base; fifth and sixth segments slightly serrate, a little longer than fourth; seventh to tenth equal in length, each a little narrower than sixth; last segment of maxillary palpi scalene triangular; eyes black, coarsely granulated. 
Pronotum about as broad as long, basal lobe in front of scutellum broad; surface minutely aciculate and punctured; scutellum broadly triangular.

Elytra about as broad as thorax, surface minutely aciculate, with fine, somewhat raised punctures; anal style long and very pointed.

Length : to apices of elytra, 1.75-2 mm.; to tip of anal style, 2-2.25 mm.

REMarKs.-This species somewhat resembles Mordellistena vapida Leconte, but is much narrower in form and differs in the color of the scutellum and undersurface and in the form of the antennae and palpi. It is one of the smallest forms of Mordellistena.

\section{Mordellistena lutea Melsheimer}

Mordella lutea Melsheimer, 1846, p. 315, Pennsylvania.

Mordellistena lutea Leconte, 1862, p. 48. Smith, 1882, pp. 85, 90. Blatchley, 1910, pp. 1310, 1316.

DesCRIPTION.-Posterior tibiae with two very oblique, converging ridges on outer face, subapical not included; first segment of posterior tarsi with two short, less oblique ridges, and second segment with one ridge.

Cuneiform; color entirely yellow testaceous, sometimes more brownish; eyes, ridges, tip of middle tibiae, and tip of hind tibiae and tarsae (which are black) densely covered with long, sericeous, yellowish gray pubescence, finer and shorter on head and thorax.

Head with surface minutely aciculate and finely punctured; eyes large. rather coarsely granulated, hairy, emarginate in front near antennae; antennae short, scarcely reaching base of thorax, filiform, or very slightly serrate, with third segment shorter than fourth, fourth a little shorter than fifth and sixth to tenth equal in length; last segment of maxillary palpi elongate, somewhat boat-shaped in male.

Prothorax very little broader than long; surface aciculate and finely punctured; basal and apical angles obtuse; basal lobe at middle, in front of scutellum, broadly rounded; scutellum triangular, rounded at apex.

Elytra finely punctured, more strongly near base; anterior tibiae curved in male; anal style long and pointed.

Length : to apices of elytra, $2.5-3 \mathrm{~mm}$.; to tip of anal style, $3.25-3.75 \mathrm{~mm}$.

REMARKs.-This species is rather rarely found. It somewhat resembles Mordellistena arida Leconte, but may be separated readily from that species by its smaller size, by having the two ridges on the first segment of posterior tarsi more separated and by having the posterior tibiae and tarsi shorter and less strongly developed; the pubescence, furthermore, is long and much coarser than it is in arida. The type of this species has not been located; it is not in the Melsheimer collection in the Museum of Comparative Zoology. The insect appears from June to August.

Previous Records.-Pennsylvania (Melsheimer); Pennsylvania and 
Georgia (Leconte and Smith); southwestern Pennsylvania (Hamilton); Cincinnati, Ohio (Dury); Marion, Orange, and Posey counties, Indiana (Blatchley).

Material examined.-Alabama: no locality (Palm, A.M.N.H.).

Delaware: Newark, June 19 (I.U.).

Illinois : northern part, July (I.U.).

Kansas : Rawlins County (Williams, K.U.).

Maryland: Plummers Island, June 28 (Barber, U.S.N.M.).

New York: Buffalo (I.U.) ; Flatbush, Long Island, August 1 (U.S.N.M.) ; no locality (Liljeblad coll.).

Pennsylvania: Jeannette (Klages); Philadelphia, June 30 (Liljeblad coll.).

Tennessee : no locality (Palm, A.M.N.H.).

\section{Mordellistena arida Leconte \\ (Pl. IV, Fig. 2)}

Mordellistena arida Leconte, 1862, p. 48, Pennsylvania. Smith, 1882, pp. 85, 90. Blatehley, 1910, pp. 1318, 1319.

Mordellistena rutila Liljeblad, 1917, p. 10.

Description.-Posterior tibiae with two very oblique, converging ridges on outer face, subapical not included and sometimes with a rudiment of a third ridge in female; first segment of posterior tarsi with three ridges and second segment with one ridge.

Cuneiform; color uniformly brownish or reddish yellow, except eyes, mandibles, tip of middle and hind tibiae, tip of hind tarsal segments, and ridges, which are black, densely covered with long, yellowish gray pubescence, finer and lighter on head and thorax.

Head minutely punctured, surface very minutely aciculate; eyes large, rounded, emarginate in front near antennae, and coarsely granulated and hairy; antennae short, reaching to base of thorax, filiform or very slightly serrate; third segment shorter than fourth, latter also shorter than fifth; sixth to tenth equal in length; last segment of maxillary palpi boat-shaped in male, elongate in female, and first segment much broader in male than in female.

Prothorax a little broader than long, finely punctured, basal and apical angles obtuse; basal lobe at middle, in front of scutellum, broadly rounded; scutellum triangular, broad at apex.

Elytra a little narrower at base than thorax, finely aciculate and finely punctured, apices a little separated; anal style long and slender.

Length : to apices of elytra, $4 \mathrm{~mm}$.; to tip of anal style, $5.5 \mathrm{~mm}$.

This species greatly resembles Mordellistena lutea Melsheimer, from which it differs mainly by its larger size and by having one more ridge on 
the first segment of hind tarsi. The pubescence on the elytra is finer, more smooth and silky, and the hind tibiae and tarsi are more strongly developed. It is more common than is lutea, but nevertheless is rather scarce in collections. Blatchley stated that it has been taken from flowers of the prickly pear cactus (Opuntia rafinesquii), and I have taken it on bur oak (Quercus macrocarpa). The type or first specimen in the Leconte collection, in the Museum of Comparative Zoology, has been examined by me; it agrees with the above description. Mordellistena rutila Liljeblad was described principally on the characters of the palpi and antennae, which afterward were found to be the same as for the female of the above species. This beetle appears from June to August.

Previous records.--Pennsylvania (Leconte) ; New York (Smith); Cincinnati, Ohio (Dury); mouth of Canyon of the Arkansas (Uhler); Lake, Porter, and Tippecanoe counties, Indiana (Blatchley) ; Bellport, New York (Nicolay); Long Island, New York (Shoemaker).

Material examined.-Arizona: Baboquivari Mountains, August 1-4 (A.M.N.H.) .

District of Columbia: Washington (U.S.N.M.).

Florida: Jacksonville, September 15 (I.U.).

Illinois : Urbana, July 8 (I.U.) ; Algonquin, July 31 (Nason coll., I.U.) ; Edgebrook, Palos Park, and Riverside, June to July (Liljeblad) ; Elgin, July 17 (Abbott) ; Henry, July 14 (Ramstadt).

Kansas : Lawrence, June (Tucker, St.U.).

Maryland: Plummers Island, June 15 (Barber, U.S.N.M.) ; Deer Park, July 4 (Hubbard and Schwarz).

Massachusetts : Framingham, August 4 (Frost).

Michigan: Grand Ledge, July 23 (Hubbard and Schwarz, U.S.N.M.).

New Jersey: Highlands, July 8 (U.S.N.M.).

New York: Spring Lake, Cayuga County, July 22 (C.U.).

Oklahoma: Atoka, June 13 (Wickham).

Pennsylvania : Reading, July 10 and Jeannette, August (Knull) ; Mount Blaine, Canonsburg, July 20 (Akerlind); Hummelstown, June 16 (Knull).

Tennessee: Cumberland County, July 10 (Hubbell, U.M.).

Virginia : Fredericksburg, June 8 (Richardson).

\section{Mordellistena knausi, new species}

Type.-From Coal Creek Canyon, Cedar City, Utah. A male, collected on June 27, at an elevation of 6250 feet, by W. Knaus; in the Museum of Zoology, University of Michigan (Liljeblad coll.).

Paratype.-A male, same data as type; in the collection of W. Knaus.

Description.-Posterior tibiae with two converging, very oblique ridges, the upper being shortest, subapical not included ; first segment of posterior 
tarsi with three ridges, upper rather short; second segment with two small ridges.

Subcuneate; head dark brown, front and mentum ferruginous, with fine grayish pubescence; antennae and palpi fusco-ferruginous; thorax dark brown, with grayish pubescence; elytra fusco-ferruginous, lighter toward base and humeral angles, covered with rather coarse, yellowish gray pubescence, finer and of a more shining appearance in one specimen; underside nearly black; legs fusco-ferruginous; anal style dark brown, finely pubescent.

Head nearly as broad as pronotum at apex, minutely punctured; antennae filiform, with fourth to tenth segments very faintly serrate; third segment one-fourth shorter than fourth; fourth segment one-fourth shorter than fifth, fifth the broadest; sixth about equal in length to fifth; seventh to tenth equal in length, each a little shorter than sixth; eleventh elongate oval, one-fourth longer than tenth; maxillary palpi with last segment elongate, parallel, as long as the two preceding segments combined; eyes rather large, coarsely granulated, hairy.

Pronotum finely punctured, as broad as elytra at base, about one-third broader than long, sides rounded and converging to apex, basal lobe in front of scutellum rounded; scutellum triangular, rounded at apex.

Elytra finely punctured, rounded at apex. Anal style long, very slender, pointed at tip.

Length: to apices of elytra, $3.25 \mathrm{~mm}$.; to tip of anal style, $4.25 \mathrm{~mm}$.; breadth, $1 \mathrm{~mm}$.

REMARKs.- This species is closely allied to the group that has the ridges on the posterior tibiae converging, such as Mordellistena arida Leconte, lutea Melsheimer, and avida Leconte, but it differs mainly from these species in the color, in the form of the maxillary palpi (the most unusual shape seen in any Mordellistena), and in having the second segment of the posterior tarsi with two ridges instead of one. The two specimens at hand differ slightly in color.

\section{Mordellistena trifasciata (Say)}

\section{(Pl. IV, Fig. 9)}

Mordella trifasciata Say, 1826, p. 243, Rocky Mountains; 1859, p. 308. Melsheimer, 1845, p. 312.

Mordellistena trifasciata Leconte, 1862, p. 48. Smith, 1882, pp. 86, 90. Blatchley, 1910, pp. 1317, 1318.

Mordellistena nigricollis Helmuth, 1864, p. 105.

Mordellistena lepidula Leconte, 1862, p. 48. Smith, 1882, pp. 86, 90. Blatchley, 1910, p. 1317.

Mordellistena amica Leconte, 1862, p. 49. Smith, 1882, pp. 87, 93. Blatchley, 1910, pp. 1322, 1323. 
Description.-Posterior tibiae with two parallel ridges, upper sometimes longer, subapical not included; first segment of posterior tarsi with two ridges and second with one ridge, all ridges well marked.

Elongate, nearly parallel; head testaceous, rarely with a dark cloud on disk; mandibles at tip and eyes black; antennae and palpi testaceous; thorax in male entirely testaceous or nearly so, female testaceous with a large, black, apical spot extended backward at middle, somewhat sinuate at sides, in some specimens leaving only a small testaceous spot at each basal angle and a narrow line at base; elytra black with two transverse yellow bands, one nearest base more or less interrupted at suture by prolongation of black basal band, and one below middle broadest near suture (in other words, with yellow as ground color, the elytra have three black bands, one at base prolonged at suture and sides, forming nearly three triangular spots connected at base, another at middle, and one at apex) ; underside in male almost entirely pale yellow or yellow-testaceous, only abdomen variegated fuscous; female nearly black, except last two or three abdominal segments which are more or less testaceous; legs usually pale in male, more or less fuscous or black in female; anal style pale at base, darker toward tip; pubescence rather long and coarse, somewhat yellowish, except on dark bands.

Head rather large, minutely punctured; antennae short, filiform, reaching to about middle of thorax, very hairy; third and fourth segments smallest, somewhat triangular, third a little shorter than fourth; fifth nearly as long as the third and fourth combined; sixth to tenth about equal in length, each a little shorter than fifth; eleventh longer than tenth, oval; last segment of maxillary palpi boat-shaped or scoop-shaped in male, elongate in female; eyes small, finely granulated, hairy.

Prothorax one-third broader than long, minutely aciculate and finely punctured; hind angles acute; basal lobe at middle, in front of scutellum, strongly developed and rounded; scutellum triangular, rounded at apex.

Elytra a little narrower than pronotum, sides very slightly tapering to near apex, surface finely aciculate, strongly but somewhat sparsely punctured; anal style long and pointed, a little more robust in female; male has anterior femora with long seta-like hairs on inner side.

Length : to apices of elytra, $2.5-3 \mathrm{~mm}$.; to tip of anal style, $3.5-4 \mathrm{~mm}$.

REMARKS.-This species can be readily distinguished by the color of the elytra, which have three black and two yellow bands. The sexes differ considerably in the last segment of the maxillary palpi, which is boat-shaped in the male and elongate in the female. The insect is rather scarce; it has been collected on the flowers of Ambrosia and Aralia.

While working to separate Mordellistena trifasciata Say, lepidula Leconte, amica Leconte, and minuta Smith, all of which had been described as bearing the same color markings on the elytra though differing to some 
extent in the color of the head and thorax and in the length of the second ridge on the posterior tibiae, I found that the first three species mentioned were identical.

Leconte separated trifasciata and lepidula from amica by the ridges on the posterior tibiae. The first two species were supposed to have two oblique, parallel ridges equal in length, and in amica the second ridge was supposed to be much longer and nearly to cross the outer tibial face. In the examination of about fifty specimens with the elytra similarly marked, only two specimens were found that could really be considered as trifasciata or lepidula, all of the remainder coming under either amica or minuta. By reason of certain other characters which have been overlooked by all previous writers, however, minuta stands apart, and, therefore, it cannot be classed with the other three. The second ridge differs in length in all the specimens examined. In some it is about equal in length to the first ridge and in others it crosses one-half, two-thirds, three-fourths, or in a few instances the entire width of the tibia. In some specimens the ridges are more oblique than in others and even differ slightly on the two legs. Because of these variations I do not consider the length of these ridges in the three species mentioned to be of important specific value.

I collected eleven specimens on a single occasion at Columbus, Ohio. A brief examination of their color pattern showed them to be either trifasciata or amica with the thorax more or less black, and lepidula with the thorax pale. According to the second ridge of their posterior tibiae they should be placed in the group near amica, but as this species has the thorax partly black, three of the eleven specimens with entirely pale thoraxes could not be included with amica, save as a variety.

A still closer study of these specimens showed that the three examples with pale thoraxes were of the male sex, and the other nine with part of the thorax black were all females. The color of the males therefore agrees with lepidula and that of the females with trifasciata or amica. The same difference in the color of the thorax holds true with two specimens, a male and a female, from Southern Pines, North Carolina.

Since the original description does not mention any differences between the sexes, I am of the opinion that trifasciata, lepidula, and amica are all one species, the oldest valid name for which is Mordellistena trifasciata (Say). The supposed types of Leconte's lepidula and amica, now in the Museum of Comparative Zoology, have been examined by me and found to be the same as trifasciata.

Previous Records.-Rocky Mountains (Say); central, western, and southern states (Leconte) ; New York (Smith) ; Catskill Mountains and Van Cortlandt, New York (Nicolay); southwestern Pennsylvania (Hamilton); Cincinnati, Ohio (Dury) ; Burlington, Iowa (Wickham) ; and Putnam, Spenser, Pulaski, and Monroe counties, Indiana (Blatchley). 
Material examined.-Alabama: Birmingham, June 20 (Soltau, U.S.N.M.) ; Langdale, Chambers County (H. H. Smith, U.S.N.M.).

Connecticut: Cornwall, June 24, August 13 (Chamberlain).

District of Columbia: Washington, June 2-27 (Hubbard and Schwarz, U.S.N.M.).

Illinois: New Lenox, July 5, and Rock Island, July 14 (Liljeblad); Henry, July 14 (Ramstadt) ; Algonquin (I.S.N.H.S.) ; Springfield, July 4 (Hart, I.U.) ; Urbana, July 13 (Kahl, I.U.) ; Monticello, August 1 (I.U.).

Iowa: Iowa City, June 4 (Stoner).

Kansas: Onega (Knaus).

Maine : Paris, July 17 (Frost).

Maryland: Plummers Island, July 24, August 4 (Schwarz, U.S.N.M.) ; Odenton, June 23 (Dietrich).

Massachusetts : Sherborn, Framingham, and Malden, June 18 to October 4 (Frost) ; Marblehead, August 23 (Miss E. W. Mank).

Michigan: Detroit (Hubbard and Schwarz, U.S.N.M.) ; Milford, June 20 (Hubbell, U.M.).

New Hampshire: Rumney (Darlington).

New Jersey: Phillipsburg, July 12, August 2 (Green).

New York: Ithaca, July 27 (C.U.); Denby, July 24 (Dietrich).

Ohio: Columbus, July 12-20 (Liljeblad).

Pennsylvania: Pittsburgh and Rockville, July (Knull).

Virginia: Drummond, June 8 (H. A. Barber, U.S.N.M.) ; Fredericksburg, June 12, July 23 (Richardson, U.S.N.M.).

\section{Mordellistena sexnotata Dury \\ (Pl. IV, Fig. 10)}

Mordellistena sexnotata Dury, 1902, p. 176, Kentucky.

Mordellistena festiva Fall (nec Champion, 1891), 1907, p. 255.

Mordellistena falli Csiki, 1915, p. 34, nom. nov. pro festiva Fall, preoccupied.

Description.-Posterior tibiae with two oblique, parallel ridges, subapical not included; first segment of posterior tarsi with two ridges and second with one ridge.

Brownish yellow, sparsely covered with coarse hairs, which are finer and more sparse on head. Humeri each with a very dark brown spot. Another in middle of elytra, beginning at base surrounding scutellum and extending backward in triangular shape about one-third the length. A large nearly round spot on each elytron at middle, but not attaining suture. And a sixth spot or band across the elytra at posterior fourth, not attaining the tip. A faintly darker spot on disk of thorax. Tibia with three oblique black ridges, the one nearest the tip being shorter. First segment of tarsi with two, second with one. Legs all pale.

Length: $3 \mathrm{~mm}$. (Dury)

REMARKS.-

One specimen, Ky. opp. Cin., O. (Dury) 
Form and size of trifasciata and lepidula. Yellow throughout, the elytra (Mordellistena festiva Fall) with black markings as follows: An elongate scutellar spot; a small humeral spot connected along the base with the former; a broad median black fascia interrupted at suture and a narrower subapical fascia. Hind tibiae with two strongly oblique, equal, parallel ridges extending half way across. Length $2 \mathrm{~mm}$.

Las Vegas, Hot Springs (Barber and Schwarz). Closely allied to trifasciata and lepidula, in both of which, however, the elytral apex is always black. (Fall)

Two specimens of this species have been seen by me, the type of sexnotata Dury, and a specimen in the United States Natural Museum from Las Vegas, Hot Springs, New Mexico, collected by Barber and Schwarz, at the same place and by the same collector as Fall's type of Mordellistena festiva. The latter specimen agrees in all respects with Fall's description, except that the subapical fascia does not quite reach the suture, but has a very narrow line of yellow dividing it. The two species are, no doubt, the same and differ from trifasciata principally by having a subapical fascia instead of an apical one.

Dury, in his description of sexnotata, stated: "Tibiae with three oblique black ridges, the one nearest the tip being shorter," and in his figure he showed the condition he described. The ridge nearest the tip proves to be the subapical one, present in all the species of Mordellistena and usually not counted with the other ridges; therefore the species sexnotata does not have more than two ridges on the tibiae. Fall, in his description of festiva, did not say anything about the ridges on the tarsal segments. Aside from the above notations, I cannot find any differences between $M$. festiva and sex. notata.

\section{Mordellistena scapularis (Say)}

$$
\text { (Pl. IV, Fig. 11) }
$$

Mordella scapularis Say, 1824, p. 277, United States; 1859, p. 164.

Mordellistena scapularis Leconte, 1862, p. 49. Smith, 1882, pp. 86, 92. Blatchley, 1910, p. 1318.

Mordellistena biplagiata Helmuth, 1864, p. 105. Smith, 1882, pp. 86, 91. Blatchley, 1910, p. 1318.

Description.-Posterior tibiae with two short, parallel, slightly oblique ridges, subapical not included; posterior tarsi with two ridges and second with one ridge. In some specimens there is a small rudimentary ridge on the tibiae as well as on the first and second segments of the tarsi.

Subcuneiform; black, with yellow or reddish yellow markings; head black with short cinereous pubescence; antennae black with three or four basal segments pale reddish yellow; maxillary palpi reddish yellow; prothorax black with sericeous, reddish yellow pubescence; scutellum with cinereous pubescence; elytra black with a yellow or reddish yellow, more or less oblong, humeral spot, not reaching scutellum, suture or lateral margin; anal style reddish yellow, sometimes more silvery; underside black, 
except abdomen which is more or less reddish yellow; legs with all femora blackish, tibiae and tarsi more or less reddish yellow.

Head comparatively large, its surface minutely aciculate and finely punctured; eyes finely granulated and hairy; antennae filiform, as long as head and thorax, a little broader in female than in male; third segment triangular, one-fourth shorter than fourth in male, subequal to fourth in female; fifth to tenth subequal in length, each a little shorter than fourth; last segment of maxillary palpi elongate, hammer-shaped in male, elongate, clubshaped, or obovate in female.

Pronotum one-fourth broader than long, rather abruptly narrowed to apex; viewed from sides slightly rounded; basal angles obtuse; basal lobe at middle in front of scutellum broadly rounded; surface finely punctured; scutellum triangular, rounded at tip.

Elytra with surface reticulate, finely punctured; apex rounded; anal style long and slender. Male usually narrower than female and with last abdominal segment one-half the length of anal style; in the female it is onefourth.

Length: to apices of elytra, 3-4.5 mm.; to tip of anal style, $4-5.75 \mathrm{~mm}$.

Remarks.-This species is very readily recognized by the ridges, although in some specimens they are somewhat variable, and by the black coloration with the humeral spot on the elytra, which in some specimens is somewhat yellow or reddish yellow. The abdomen is also variable in color, ranging from reddish yellow to nearly entirely black.

According to Leconte and other writers, M. biplagiata differs from scapularis only by having no third ridge on the first segment of posterior tarsus and no second ridge on the second segment. After a careful study of a large series of biplagiata I found that many specimens have the ridges snentioned by Leconte as occurring in scapularis, but they are of a rudimentary nature and often are different on the two legs. Say, in his description, did not mention any ridges; they were reported by Leconte thirtyeight years later. Since no other characters have been suggested to separate the two species, I am convinced that the two are the same. The humeral spot is somewhat variable in size. J. B. Smith stated that he had seen a specimen only $1.7 \mathrm{~mm}$. in length from the Catskill Mountains, New York. In the vicinity of Chicago, Illinois, this species is rather common on flowers in early summer. It appears from May to August.

Previous Records.-United States (Say); Illinois (Helmuth); New York (J. B. Smith); Cincinnati, Ohio (Dury); Indiana (Blatchley).

Material examined.-Illinois : Algonquin, June 1 (I.S.N.H.S.) ; Evanston, Fort Sheridan, Palos Park, Beverly Hills, Willow Springs, Edgebrook, and Eggers, May 20 to July 19 (Gerhard, Wolcott, Selinger, and Liljeblad); Rock Island, July 4 (Liljeblad). 
Maine : Paris, Wales, and Monmouth, June 1 to July 15 (Frost).

Manitoba: Aweme, July 20 (Criddle).

Maryland: Plummers Island, June 7 (McAtee, U.S.N.M.).

Massachusetts: Hopkinton, May 25, Natick, May 29, Framingham, June 5, Duxbury, June 27, Sudbury, July 4, and Sherborn, June 16 (Frost).

Michigan: Charity Island, June 23 (Andrews); Washtenaw County, June 10 (Hubbell); Whitehall and Pentwater, July 12 to July 20 (Liljeblad).

New Brunswick : Bathurst, June 25 (Knull).

New Hampshire: Mount Pleasant, July (Frost).

New York: Ithaca, May 9 to June 17, Peekskill, June 18, and Peru, June 10 (C.U.) ; Port Byron, Cayuga County, June 30 (Dietrich) ; Middletown, July 2 to 20 (Spooner).

Nova Scotia: Millsville (C.U.).

Ontario: Toronto and Forks Credit (Crew coll., C.U.) ; Prince Edward County, July 26 (Brimley).

Quebec: Aylmer, June 11 (Knull).

\section{Mordellistena limbalis (Melsheimer)}

(P1. IV, Fig. 12)

Mordella limbalis Melsheimer, 1846, p. 315, Pennsylvania.

Mordellistena limbalis Leconte, 1862, p. 49. Smith, 1882, pp. 86, 90. Blatchley, 1910, pp. 1317, 1318.

Description.-Posterior tibiae with two parallel, oblique ridges, subapical not included ; first segment of posterior tarsi with two ridges and second with one ridge.

Slender, nearly parallel; color testaceous, with black markings; head testaceous with a dusky cloud between eyes; antennae pale at base, dusky outwardly; palpi dusky ; mandibles black at tip; thorax pale testaceous with a black spot on disk, varying in outline, triangular, rhomboidal, or sometimes oval; anterior angles more or less dusky; elytra testaceous with suture and lateral margins black, lateral broadest, basal margin in some specimens a little dusky; legs and metasternum pale, pectus and abdomen more or less dusky; pubescence long, yellowish, except at base and sides of elytra and middle of thorax, where it is black.

Head densely and minutely punctured; eyes small with short fine hairs, finely granulated; antennae filiform, two last segments reaching below thorax, third segment small, triangular, a little shorter than fourth; fifth to tenth about equal in length, each slightly narrowing to tenth; eleventh onethird longer than tenth, oval; last segment of maxillary palpi boat-shaped, much broader in male than in female.

Pronotum one-fourth broader than long, rather convex, very slightly 
broader than elytra at base; hind angles obtuse; basal lobe at middle in front of scutellum rounded; scutellum small, triangular, broadly rounded at tip.

Elytra very slightly tapering to near apex, surface with fine raised punctures, apex rounded; anal style long and very slender, pointed.

Length : to apices of elytra, $3.25 \mathrm{~mm}$.; to tip of anal style, $5 \mathrm{~mm}$.

REMARKs.-This species is comparatively easy to identify being readily distinguished by the markings on the elytra, which have the suture and margin black. The elytral markings are rather constant, but the dorsal spot on the thorax varies somewhat in size and shape and sometimes the dark markings of the underside are entirely absent. In Melsheimer's collection, in the Museum of Comparative Zoology, there are two specimens of this species labeled "Oregon" which agree with the above description. The species appears from June to August and has been taken on the flowers of spirea and other plants. It is comparatively scarce in collections.

Previous Records.-Pennsylvania (Melsheimer); middle states (Leconte) ; New York (Smith) ; Cincinnati, Ohio (Dury); Ames, Iowa (Wickham) ; Lake, Tippecanoe, and Knox counties, Indiana (Blatchley).

MATERIAL EXAMINED.-District of Columbia: Washington (U.S.N.M.).

Illinois: Eggers, July 7 (Wolcott) ; Muncie, July 25 (I.S.N.H.S.) ; Springfield, June 27 (Hart, I.U.).

Indiana: Lafayette, July 5 (Wolcott).

Kansas : Douglas County (Alexander, K.U.).

Kentucky: Louisville, June 22 (Soltau, U.S.N.M.).

Maine: Monmouth, Paris, and Wales, July 5 to 30 (Frost).

Manitoba: Aweme, July 20 (Criddle).

Maryland: Plummers Island, June 15 (Barber, U.S.N.M.).

Massachusetts : Sherborn and Framingham, July 17 to 28 (Frost) ; Attleboro, June 27 (Frost).

Michigan: Huron Mountains, Marquette County, July 11 (Hubbell); Milford, June 21 to 26 (Hubbell, U.M.).

New Hampshire: Durham, July 21 (I.U.).

New Jersey : Phillipsburg, July 19 (Green).

New York: Ithaca (Green).

North Carolina: Crestmont, Haywood County, July 19 (Hubbell).

Nova Scotia: Truro, July 4 (Matheson, C.U.).

Pennsylvania: Easton and Pocono Lake (Green); Jeannette (Klages).

Virginia: Rosslyn, August 7 (H. H. Smith).

\section{Mordellistena elegantula Smith}

Mordellistena elegantulus Smith, 1882, pp. 86, 90, Long Island.

Description.-Posterior tibiae with two parallel, oblique ridges on outer face, subapical not included; first segment of posterior tarsi with two and second with one ridge. 
Yellow; above clothed with dense sericeous pubescence; apical margin of thorax, suture, broad median band and apex of elytra dark fuscous.

Length: $2.5 \mathrm{~mm}$. (Smith)

REMARKS.-

Long Island. Differs from the other species in this section by the pale color and brown markings. One specimen only, from Long Island, my collection. (Smith)

This species is unknown to me. The markings given by Smith in his figure seem to separate this species from the others in this group, but how much it differs from the variation $b$ of Mordellistena trifasciata Melsheimer, which has the basal band of the elytra wanting, I am unable to say. The figure (Pl. II, Fig. 21) from Smith's synopsis does not agree with the statement in his key, "apical margin of thorax dark fuscous," whereas the figure shows the basal margin black, not the apical.

A specimen under this name, in the United States National Museum, marked type, No. 1239, has no locality label and does not agree with Smith's description.

\section{Mordellistena dimidiata Helmuth}

(Pl. IV, Fig. 13)

Mordellistena dimidiata Helmuth, 1864, p. 105, Illinois. Smith, 1882, pp. 86, 90. Blatchley, 1910, pp. 1317, 1319.

Description.-Posterior tibiae with two oblique, parallel ridges, subapical not included ; first segment of posterior tarsi with two ridges in male and a strongly marked, third rudimentary ridge in female; second segment with one ridge in male and a rudiment of a second in female.

Linear; color for the most part reddish yellow, with black markings; head, thorax, antennae at base, anal style, anterior and middle legs, and posterior femora and tibiae reddish yellow, ridges black; elytra reddish yellow from base to near middle; apical half more fuscous, suture and side margin black; pubescence on head and thorax light yellow, on elytra more brownish yellow; underside reddish yellow, abdomen black or nearly so.

Head with surface very finely aciculate and minutely punctured; eyes somewhat large, with short hairs, rather coarsely granulated; antennae about as long as head and thorax, filiform, with third segment triangular, onefourth shorter than fourth; fifth to tenth about equal in length, each a little shorter than fourth; eleventh oval ; last segment of maxillary palpi elongate, scalene triangular.

Pronotum about one-third broader than long, surface finely punctured; sides evenly rounded to apex when viewed from above, margin very slightly curved when viewed from side; basal angles acute; basal lobe at middle, in front of scutellum, rounded; scutellum triangular, broadly rounded at tip.

Elytra very slightly tapering to near rounded apex with fine distinct margin; surface reticulate and with rather deep punctures; anal style comparatively long and very slender. 
Length: to apices of elytra, $3-3.75 \mathrm{~mm}$.; to tip of anal style, $4-4.75 \mathrm{~mm}$.

REMARKS.-The type of this species has disappeared and probably has been destroyed. I collected two specimens, a male and a female, from Illinois, that agree with Helmuth's description. Since these are from the type locality, the male has been selected as lectotype.

This species somewhat resembles Mordellistena tosta Leconte, which, however, does not have the elytral suture and side margin black. A darker form has been observed from Rumney, New Hampshire, which comes very close to the present species, but differs by being more robust and, in some specimens, by having the meso- and metasternum, as well as the abdomen, dark. This may be Mordellistena errans Fall, according to specimens so identified by that author; however, his description reads, "entirely testaceous," and consequently errans cannot well be the same as dimidiata. The Rumney specimen, therefore, is placed with dimidiata in my collection, as a variety. The species seems to be rather rare.

Previous RECORD.-Illinois (Helmuth).

MATERIAL EXAMINED.-Alabama: Birmingham, June 20 (Soltau, U.S.N.M). Illinois : Glencoe, July 6 (Liljeblad).

Massachusetts : Framingham and Sudbury, July 4 (Frost).

New Hampshire: Rumney, July 13, August 25 (Darlington).

New York: Olcott, July 4 (Dietrich and Miss E. W. Mank) ; Van Courtland Park (A.M.N.H.).

Pennsylvania: Natron, July 12 (Dietrich).

Texas : Brownsville, June 11 (U.S.N.M.).

\section{Mordellistena vilis (Leconte) \\ (Pl. IV, Fig. 5)}

Mordella vilis Leconte, 1858, p. 76, California.

Mordellistena vilis Leconte, 1862, p. 49. Smith, 1882, pp. 86, 91.

Description.-Posterior tibiae with two parallel, oblique ridges, subapical not included; first segment of posterior tarsi with two ridges, sometimes with rudiment of third ridge, second with one ridge.

Elongate, sublinear; entirely black, except for antennae in female, which are somewhat dusky brown, sparingly covered with sericeous, reddish brown and gray pubescence.

Head moderately large, but somewhat longer than usual; surface very minutely aciculate and finely punctured; eyes elongate oval, finely granulated and hairy; antennae very short, not longer than head (or, when head is recumbent, reaching to middle of thorax), filiform, very slightly broadening to apex; third segment a little longer than fourth; fifth nearly as long as third and fourth combined; sixth to tenth subequal in length, each onefourth shorter than fifth; eleventh oval; female antennae with third and 
fourth segments equal in length, each a little longer than in male; last segment of maxillary palpi scalene triangular.

Pronotum very little broader than elytra at base, about as broad as long; surface minutely aciculate and finely punctured; basal angles subacute, apical angles rounded; basal lobe at middle, in front of scutellum, rounded; scutellum triangular, rounded at tip.

Elytra nearly parallel to near apex; surface minutely aciculate, punctures fine and somewhat raised, more so near base; apex rounded and with distinct margin; anal style rather long and pointed.

Length : to apices of elytra, $1.75-2 \mathrm{~mm}$. ; to tip of anal style, $2.6-3 \mathrm{~mm}$.

REMARKs.-This small species, presumably restricted to the western states, is easily recognized by its small size, its unusually long head, and elongated eyes. The ridges on the legs are mostly very small and, therefore, difficult to distinguish. It resembles very closely the eastern Mordellistena pauxilla Liljeblad, but this has much longer antennae, and the last segment of the maxillary palpi is rounded. The first specimen under the name vilis in Leconte's collection, in the Museum of Comparative Zoology, is no doubt the type from California, although it is in rather poor condition; the other two under that name are not vilis. Several specimens from the eastern states have been named erroneously as this species by me as well as by others, before some of the best distinguishing characters were found for the separation of this form. The localities of these misidentified specimens cannot be included, for they may belong to Mordellistena pauxilla.

Previous Records.-San Diego, California (Leconte); Mount Vitis, British Columbia (Selyvn); and Cincinnati, Ohio (Dury).

Material examined.-California: San Diego, May 25 (Psota); Felton, Santa Cruz Mountains, May 15 (Bradley, C.U.) ; Mount Lowe, July 24 (Miss E. W. Mank) ; San Bernardino County, June (Coquillet, U.S.N.M.) ; La Mesa, San Diego County, April 21 (L. O. Howard, U.S.N.M.).

Colorado : Regnier, June 6-9 (A.M.N.H.).

Texas : San Diego, June 26 (Schwarz, U.S.N.M.).

\section{Mordellistena pauxilla, new species}

(P1. IV, Fig. 6)

Trpe.-From Palos Park, Illinois. A male, collected June 25 by Emil Liljeblad; in the Museum of Zoology, University of Michigan (Liljeblad coll.).

Paratypes.-Two males, same data as type.

Description.-Posterior tibiae with two short, parallel oblique ridges, subapical not included; first segment of posterior tarsi with two ridges and second with one ridge.

Nearly linear; entirely black, except three or four basal segments of 
antennae which are dark rufous, covered with rather coarse cinereous pubescence.

Head large, as broad as elytra at base, surface minutely aciculate; eyes rather coarsely granulated and hairy; antennae filiform, longer than head and thorax, very hairy ; third segment shortest, triangular; fourth one-third longer than third; fifth one-third longer than fourth; sixth to tenth about equal in length, each very little longer than fifth; female with antennae as in male, but with segments a little shorter; last segment of maxillary palpi somewhat scalene, rounded on inner angle.

Pronotum one-fifth broader than long, broader than elytra at base, surface minutely aciculate; lateral margin slightly rounded; basal and apical angles obtuse; basal lobe at middle, in front of scutellum, rounded; scutellum small, rounded at tip.

Elytra nearly parallel to near apex; surface aciculate and reticulated with fine punctures; apex rounded, with distinct margin. Anal style short and slender.

Length: to apices of elytra, $2.25 \mathrm{~mm}$; to tip of anal style, $2.75 \mathrm{~mm}$.

Remarks.- This species is most nearly related to Mordellistena vilis Leconte, but differ from it in color, in the length of the antennae, and in the shape of the maxillary palpi.

\section{Mordellistena paradisa, new species}

Type.-From Paradise Key, Florida. Collected March 3, by Schwarz and Barber; in the United States National Museum.

Paratrpes.-Three from Crescent City, Florida, one from Poinsette, Florida, May 1, and one from Capron, Florida, April 11, all collected by Hubbard and Schwarz.

Description.-Posterior tibiae with two small, oblique ridges, subapical not included ; first segment of posterior tarsi with two ridges and second with one ridge.

Elongate, narrow; upper part of head dark; underside, hind femora, and base of anal style more or less black; fore part of head, mouth parts, antennae, palpi, front and middle legs, hind tibiae and tarsi, and apex of anal style yellowish, surface rather sparingly covered with yellowish pubescence.

Head nearly as broad as thorax, minutely aciculate and punctured; eyes pointed below antennae, coarsely granulated and hairy; antennae short, subfiliform, very little dilated toward apex; fifth segment about as long as third and fourth combined; third a little longer than fourth; last segment of maxillary palpi elongate, with inner and outer sides not angulated.

Pronotum about as broad as long; sides nearly straight; basal angle subacute; surface minutely aciculated and punctured.

Elytra as wide at base as thorax, sides nearly parallel two-thirds from 
base toward rounded apex; surface finely aciculate and punctured. Undersurface more strongly punctured. Anal style long and pointed.

Length : to apices of elytra, $1.5 \mathrm{~mm}$; ; to tip of anal style, $2.25 \mathrm{~mm}$.

ReMarks.-This species is somewhat like Mordellistena vapida Leconte, but cannot be identified with it, although it resembles it in color and has the same number of ridges on the posterior legs. The present species is narrower and shorter than vapida, its antennae are more filiform, not at all serrate, and the last segment of the maxillary palpi is rounded on the inner angle.

\section{Mordellistena fulvicollis (Melsheimer)}

Mordella fulvicollis Melsheimer, 1846, p. 315, Pennsylvania.

Mordellistena fulvicollis, Lcconte, 1862, p. 49. Smith, 1882, pp. 86, $92 . \quad$ Blatchley, 1910, p. 1318.

Description.-Posterior tibiae with two parallel, oblique ridges and a rudiment of a third ridge in some specimens, subapical ridge not included; first segment of posterior tarsi with two ridges and a rudimentary third ridge, second with one ridge.

Elongate; head, thorax, antennae, palpi, and anterior and middle legs, yellow or testaceous yellow; posterior tibiae and tarsi, anal style and last two segments of abdomen darker or reddish yellow, females usually darker than males; elytra nearly black, with long, somewhat sparse, light reddish yellow pubescence; base in some specimens, especially males, with a faint ferruginous area, and extreme apical margin also more or less yellowish ferruginous; posterior femora and underside black or nearly so.

Head broad, surface minutely aciculate and punctured; antennae long, filiform, reaching quite below thorax; third and fourth segment short, combined about as long as fifth; sixth to tenth subequal in length, each a little shorter than fifth; last segment of maxillary palpi scalene triangular; eyes rather coarsely granulated and hairy.

Pronotum one-third broader than long; surface minutely aciculate and finely punctured; basal angle obtuse; basal lobe at middle in front of scutellum broadly rounded. Scutellum triangular.

Elytra with sides nearly parallel to near rounded apex; surface finely aciculate with rather coarse, raised punctures. Anal style long, narrow, and pointed.

Length : to apices of elytra, $2-2.5 \mathrm{~mm}$; t to tip of anal style, $3-3.5 \mathrm{~mm}$.

REMARKS.-This species is easily recognized, after the ridges have been examined, by the yellowish head and thorax and the black elytra with the extreme apex pale. The figure given by J. B. Smith, in his synopsis, shows the pale basal and apical areas entirely too large. The supposed type or first specimen in Melsheimer's collection, now in the Museum of Comparative Zoology, is a male and agrees with his description, especially with his variety $a$. 
Previous Records.-Pennsylvania (Melsheimer); Illinois (Leconte); New Jersey (Smith); Cincinnati, Ohio (Dury).

Material EXAMined.-Illinois : Edgebrook, July 16 (Liljeblad).

Maryland : Pineypoint (Hubbard and Schwarz, U.S.N.M.).

Massachusetts : Sherborn (Frost).

Michigan : Pigeon, Huron County, June 29, on Caprinus (Hussey).

Virginia: Pennington Gap, June 30 (Hubbard and Schwarz, U.S.N.M.).

\section{Mordellistena vapida Leconte}

(Pl. IV, Fig. 7)

Mordellistena vapida Leconte, 1862, p. 49, Pennsylvania. J. B. Smith, 1882, pp. 86, 91. Blatchley, 1910, pp. 1317, 1319.

DESCRIPTION.-Posterior tibiae with two oblique, parallel ridges on outer face, subapical not included ; first segment of posterior tarsi with two ridges and second with one ridge.

Subcuneiform; entirely luteous, except eyes which are black; surface sparsely covered with sericeous, coarse yellowish pubescence; a little darker shading is visible on apical half of elytra, due to effect of dark wings underneath.

Head about as broad as elytra at base, with its surface minutely aciculate, finely punctured; eyes prominent, coarsely granulated, hairy; antennae short, filiform, or very slightly serrate, reaching to about middle of thorax, a little longer in female; third and fourth segments small, triangular; fifth segment one-third longer than fourth and much broader at apex; sixth nearly equal in length to fifth; seventh to tenth equal in length, each a little shorter than sixth; eleventh oval; last segment of maxillary palpi elongate, securiform, more rounded at inner angle in female.

Pronotum about one-fifth broader than long; basal angles subacute, hind angles rounded; surface minutely aciculate and finely punctured; basal lobe at middle in front of scutellum broadly rounded; scutellum triangular, somewhat pointed.

Elytra at base a little narrower than thorax; surface with raised punctures; sides from middle gradually tapering to apex, which has a fine margin; male with last abdominal segment slightly cleft or emarginate at apex, rounded in female; anal style short, pointed in male, much longer in female.

Length : to apices of elytra, $2.5 \mathrm{~mm}$; t to tip of anal style, $3.25 \mathrm{~mm}$.

REMARKs.-This is a rather rare species. I have seen only a few specimens, including the supposed type in the Leconte collection, in the Museum of Comparative Zoology, which agrees with Leconte's description. It resembles several other paler forms, but may best be recognized by the ridges on the legs and by the shape of the antennae and palpi. 
Previous Records.-Pennsylvania (Leconte); New York (Smith); Cincinnati, Ohio (Dury) ; Iowa City, Iowa (Wickham) ; Orange County, Indiana, May 28 (Blatchley).

Material examined.-Illinois : Edgebrook, August 14 (Liljeblad).

Maryland : Plummers Island, June 2 (Schwarz, U.S.N.M.).

Ohio: Columbus, July 20 (Liljeblad).

\section{Mordellistena intermixta Helmuth}

(Pl. IV, Fig. 8)

Mordellistena intermixta Helmuth, 1865, p. 96, Illinois. J. B: Smith, 1882, pp. 86, 91. Blatchley, 1910, p. 1318.

Description.-Posterior tibiae with two equal, parallel ridges on outer face, subapical not included; first segment of posterior tarsi with two ridges and second with one ridge.

"Black, mouth, front legs and elytra piceous; pubescence of elytra dark brown, with light hairs intermixed" (Helmuth).

REMARKs.-I have been unable to find any specimen that agrees with the original description. Two specimens have been received from Massachusetts that may belong to this species, judging by the color of the elytra, but their head and thorax are not black. J. B. Smith stated: "Readily recognized by the contrast in color between the thorax and elytra, the latter of which is sometimes more rufous. Specimens from California and New York (Adirondack Mountains) agree in every respect with each other and with the description." There cannot be very much contrast, however, between black and piceous, and as the type is, no doubt, destroyed, at least one specimen should be found with the color exactly as described by Helmuth before the species is redescribed.

\section{Mordellistena bipustulata Helmuth}

Mordellistena bipustulata Helmuth, 1864, p. 105, Illinois. Smith, 1882, pp. 86, 91.

DESCRIPTION.-

Posterior tibiae wtih two oblique, parallel, equal ridges, the subapical not included; first and second joints of posterior tarsi each with two ridges.

Black; mouth, front, two small spots on the apical margin of the thorax, and anterior feet reddish-yellow; pubescence light-brown sericeous. (Helmuth)

REMARKs.-This species is unknown to me. A few specimens have been seen, which agree with the description in color but not in ridges.

\section{Mordellistena atriceps Smith}

Mordellistena atriceps Smith, 1882, pp. 86, 91, New York.

\section{DESCRIPTION.-}

Hind tibiae with two oblique ridges on outer face; ridges parallel equal; first and second joints of hind tarsi each with two oblique ridges. 
Fulvo-piceous with fine dense sericeous pubescence, head slightly paler; tibial ridges more oblique than usual.

Length: $4 \mathrm{~mm}$.

Distinguished from the preceding ( $M$. bipustulata) by the paler color, larger size, heavier form, and the longer and unusually oblique tibial ridges. One specimen only, my collection. (Smith)

Remarks.-This species is entirely unknown to me, and the type has not been located.

\section{Mordellistena pratensis Smith}

Mordellistena pratensis Smith, 1883, p. 80, Florida.

\section{DESCRIPTION.-}

Posterior tibiae and first and second joints of posterior tarsi each with two short oblique ridges; all distinctly marked.

Body black, elytra golden yellow with fine sericeous pubescence; suture and side margins narrowly fuscous; legs all pale.

[Length:] $1 \frac{1}{2} \mathrm{~mm}$.

A single specimen in $m y$ collection differing from all others in its group by the color of elytra. (Smith)

REMarks.-The supposed type of this species, from Florida, now in the Museum of Comparative Zoology, agrees very well with the above description, but also agrees somewhat with the description of a female Mordellistena dimidiata, although it is much smaller in size. As no specimens of dimidiata from Florida have been available for study and as the antennae and palpi could not be examined on the type of pratensis, I do not find it advisable for the present to place this species in synonymy.

\section{Mordellistena errans Fall}

Mordellistena errans Fall, 1907, p. 257, Massachusetts.

\section{DESCRIPTION.-}

Hind tibiae with two rather short oblique ridges, not reaching the middle of the face of the tibiae, and a very small rudimentary third ridge; first and second joints of hind tarsi with two very oblique ridges, the second joint with rudiments of a third ridge.

Entirely yellow testaceous. Terminal joint of maxillary palpi broadly triangular, scarcely one-half longer than wide, the apical edge as long as the inner. Fourth antennal joint longer than the fifth.

Length: $3.6 \mathrm{~mm}$.

Tyngsboro, Mass. (Mr. Blanchard).

The fourth antemnal joint longer than the fifth is a rery unusual character, which I do not recall seeing elsewhere. (Fall)

REMARKs.- The type has not been seen by me, but if it is as described, entirely yellowish testaceous without any markings, then it undoubtedly represents a good species. 


\section{Mordellistena picipennis Smith}

Mordellistena picipennis Smith, 1882, pp. 86, 91, New York, Georgia. Blatchley, 1910, p. 1318.

\section{DESCRIPTION.-}

Hind tibiae with two oblique ridges on the outer face. Ridges parallel, equal. First joint of hind tarsi with three, second with one oblique ridge.

Piceous, clothed with brown sericeous pubescence; elytra paler, piceo-testaceous.

Length: $4 \mathrm{~mm}$.

New York, Georgia.

The combination of tibial and tarsal ridges peculiar to this and the two following species (M. pallipes and $M$. fulvicollis) is shown on Plate II, figure 25. Distinguished from the others in this group by not having the elytra variegated. Three specimens, New York; two, my collection; Georgia, one, coll. Dr. Horn. (Smith)

Remarks. - The type has not been located. Several specimens in the United States National Museum and three in my collection very probably belong to this species. They have a rudimentary ridge on the posterior tibiae and some of them also have a small rudiment of a second ridge on the second segment of the posterior tarsi. Head and thorax entirely black or nearly so, with silky, yellowish gray pubescence; elytra entirely dark reddish brown; underside nearly black; palpi reddish brown; basal segments of antennae reddish brown, apical segments black; anterior and middle legs reddish brown; posterior tibiae and tarsi dark; anal style black; antennae filiform, with third and fourth segments short, both combined as long as or shorter than fifth; eyes finely granulated, with short hairs; last segment of maxillary palpi elongate, scalene triangular in male, more elongate and with shorter apical side in female.

The present species is rather difficult to identify by its short original description, as the color and the ridges are very similar to those of two other species, and no other characters are given for separation. The type or type series has not been located, and it is therefore uncertain if the specimens identified by me as of this species are like those described by Smith.

Material examined.-Florida: Orange County, May 11 (U.S.N.M.).

Maryland: Plummers Island, June, "breed in chestnut" (Schwarz and Barber, U.S.N.M.).

New York: Olcott, July 4 (Miss E. W. Mank).

Pennsylvania: Phillipsburg, August 2 (J. W. Green).

Virginia: Pennington Gap, July 2 (Hubbard and Schwarz, U.S.N.M.).

\section{Mordellistena pallipes Smith}

Mordellistena pallipes Smith, 1882, pp. 86, 92, New York.

\section{DESCRIPTION.-}

Hind tibiae with two oblique ridges on the outer face. Ridges parallel, equal. First joint of hind tarsi with three, second with one oblique ridge. 
Piceous; legs pale, elytra rufous, suture and margin blackish; tibia with a distinct rudiment of a third ridge.

Length: $2.5 \mathrm{~mm}$., N. Y.

All the legs pale testaceous - an unusual character in the genus-this point and the darker margins of elytra render the species readily recognizable. The rudiment of the third ridge is very short, having but two or three spinules but the pale color of the legs renders it easily noted, as the spinules are black. One specimen, Ithaca, N. Y. my collection. (Smith)

REMARKs.-I have three specimens that undoubtedly belong to this species, although the legs are darker than is reported in the description. Smith said that his species "has the legs pale testaceous, an unusual character in this genus," but the same character is present in lutea, arida, tosta, and many others; he also stated that the color is piceous with the elytra rufous, but in his figure the thorax is entirely pale. The specimens before me differ so slightly from Smith's description that it is unwarrantable to describe them as new. The species, therefore, may be redescribed as follows :

Posterior tibiae with two equal, parallel, oblique ridges, and a rudiment of a third ridge, subapical not included; first segment of posterior tarsi with three short ridges and second with one ridge.

Cuneiform; head black except near mouth parts, covered with cinereous pubescence; antennae dark testaceous, a little darker at base; palpi testaceous; thorax black, covered with cinereous pubescence; scutellum dark testaceous; elytra testaceous with suture and margin black and with yellowish pubescence; underside black; anterior legs more or less testaceous, middle legs darker; posterior femora and tibiae black, tarsi dark testaceous; anal style black.

Head minutely aciculate and with very fine punctures, denser at sides; eyes finely granulated and with short hairs; antennae short, slightly serrate, about as long as head and thorax; third segment shortest, triangular, onefourth shorter than fourth; fifth to tenth segments about equal in length; last segment of maxillary palpi short, scalene triangular.

Pronotum about one-fourth broader than long'; surface minutely aciculate and with fine raised punctures; basal angle subacute, apical angle rounded; basal lobe at middle in front of scutellum broadly rounded; scutellum small.

Elytra attenuate; apex rounded, with fine margin; surface with fine raised punctures; anal style short, slender.

Length : to apices of elytra, $2.5 \mathrm{~mm}$.; to tip of anal style, $3 \mathrm{~mm}$.

This species is readily recognized by the black head and thorax and by the testaceous elytra with suture and margin blackish. It differs from limbalis and dimidiata by having the head and thorax black and also by having somewhat differently shaped maxillary palpi. The type has not been located. The insect seems to be very rare. 
Previous Record.-Ithaca, New York (Smith).

Material examined.-Manitoba: Aweme, June 26 (Criddle).

Massachusetts: Framingham and Natick, June 3 and 5 (Frost).

Michigan : Grand Ledge, July 23 (Hubbard and Schwarz, U.S.N.M.).

New Hampshire: Tamworth, June 22 (Darlington).

\section{Mordellistena nebulosa, new species}

(Pl. IV, Fig. 14)

Type.-From Columbus, Ohio. Collected July 12 by E. Liljeblad; in the Museum of Zoology, University of Michigan (Liljeblad coll.).

Description.-Posterior tibiae with two short oblique ridges and a rather strongly marked rudimentary third ridge, subapical ridge not included; first segment of posterior tarsi with three ridges and second with one small ridge.

Linear; head, thorax, antennae, and palpi very dark reddish brown; elytra black, covered with long, sparse, yellowish gray pubescence; underside more or less fuscous; abdomen black; anterior leg's, middle femora, and posterior femora and tibiae dark testaceous, middle tibiae and tarsi and posterior tarsi black, anal style black.

Head comparatively large, surface minutely aciculate and with very fine punctures; eyes finely granulated, scarcely at all hairy; antennae filiform, scarcely as long as head and thorax; third segment a little longer than fourth; fifth twice as long as fourth, with sides parallel; sixth to tenth about equal in length, each one-fourth shorter than fifth; eleventh oval; last segment of maxillary palpi scalene triangular, inner and apical sides nearly equal in length.

Pronotum about as broad as long, basal angles acute, apical angles rounded, basal lobe rounded at middle in front of scutellum, surface minutely aciculate and punctured; scutellum small, triangular.

Elytra parallel to about one-third from apex, thence rather abruptly tapering to a pointed apex; surface very finely aciculate, with fine raised punctures. Anal style moderately long and slender.

Length : to apices of elytra, $2.5 \mathrm{~mm}$.; to tip of anal style, $3.25 \mathrm{~mm}$.

REMARKs.- The only specimen at hand, a male, of this peculiarly colored Mordellistena, does not resemble any other known North American species. It may be recognized by its dark reddish brown head and thorax and black elytra. The sparse, light pubescence on the black elytra appears very distinct; the ridges are small and somewhat difficult to distinguish. The last segment of the maxillary palpi is unusually small, and the fifth to tenth antemnal segments are parallel.

\section{Mordellistena ornata (Melsheimer)}

(PI. IV, Fig. 15)

Mordella ornata Melsheimer, 1846, p. 315, Pennsylvania. 
Mordella pectoralis Leconte, 1850, p. 231, Kakabeka; 1862, p. 50. J. B. Smith, 1882, pp. 88, 95.

Mordellistena decorella Leconte, 1862, p. 49. J. B. Smith, 1882, pp. 86, 91. Blatchley, 1910, p. 1318.

Mordellistena ornata Leconte, 1862, p. 49. J. B. Smith, 1882, pp. 86, 92. Blatchley, 1910, p. 1318.

Description.--Posterior tibiae with two oblique, parallel ridges on outer face, subapical not included; first segment of posterior tarsi with three ridges in male and two in female, second segment with two ridges. A small rudimentary ridge may be found in some specimens on the tibiae as well as on the tarsal segments.

Subcuneiform; slender, black with yellowish markings; head either entirely testaceous or with vertex more or less black-some specimens testaceous only near mouth parts; antennae testaceous, a little cloudy at tip; palpi testaceous; prothorax variable in color, sometimes with basal half black and apical half testaceous, sometimes with basal half black and a large spot at middle near apex leaving a somewhat quadrate testaceous spot each side, or sometimes almost entirely black, with only a very small testaceous spot on each side near apical angle; scutellum testaceous; elytra black with a rather large triangular yellowish humeral spot, which reaches downward to near middle; a more or less testaceous sutural line from near base of elytra almost to apex, broadened one-third from apex, forming an obsolete band which, in some specimens, is connected with a short marginal line extending downward from middle; whole surface somewhat coarsely and sparsely covered with yellowish gray pubescence; underside variable in color, entirely yellowish or testaceous, or sometimes distinctly blackish on sides and abdominal segments; legs pale, except on hind tarsi which, in some specimens, are a little fuscous; anal style pale, rarely dusky.

Head moderate in size, surface minutely aciculate and finely punctured; eyes prominent, rather coarsely granulated and hairy; antennae filiform, a little more serrate in female, third segment narrow, short; fourth segment one-third longer than third and much broader; fifth equal in length to fourth; sixth to tenth subequal in length, each a little shorter and narrower than fifth; eleventh oval; last segment of maxillary palpi elongate, with apical side one-third shorter than the inner.

Pronotum about one-third broader than long, broadest near base; basal angles obtuse, apical angles broadly rounded; surface finely aciculate and punctured; basal lobe broadly rounded at middle in front of scutellum; scutellum small, triangular, rather broadly rounded at tip.

Elytra attenuated; surface with fine raised punctures; apex rounded; anal style somewhat long and slender.

The female is a little broader than the male and has a shorter anal style.

Length : to apices of elytra, $2.75-4 \mathrm{~mm}$; to tip of anal style, $3.75-5 \mathrm{~mm}$. 
REMARKS.-This rather handsome species is easily distinguished from all other species in Mordellistena by the coloration of the elytra. The color of the head, thorax, and underside is somewhat variable, and the number of ridges on the first segment of the hind tarsi also varies from two to three. While making the above notation, I had before me forty-two specimens and found none among them to warrant the recognition of Leconte's decorella, although its description is applicable to the females of Melsheimer's ornata, the type of which is a male. Some specimens have a rather strong rudimentary ridge on the posterior tibiae and the first segment of the tarsi, in agreement with the description of Mordellistena pectoralis Leconte. Since the third ridge is not equally strong on both leg's, it cannot be considered as more than rudimentary, and since the type of pectoralis is identical with ornata except in respect to the ridges, I believe that pectoralis does not possess strong enough characters to be worthy of a name.

The types of the three above mentioned species are supposed to be in the Museum of Comparative Zoology, but only two could be located, ornata and pectoralis, and both agree with the description as given on the preceding page.

Previous Records.-Pennsylvania (Melsheimer); central and southern states (Leconte); southwestern Pennsylvania (Hamilton); Cincinnati, Ohio (Dury) ; Ames, Iowa (Wickham) ; and throughout Indiana, May 21 to July 13 (Blatchley).

Material examined.-Colorado : no locality (Crew coll., C.U.).

District of Columbia: Washington, June 13 (Hubbard and Schwarz).

Illinois: Edgebrook, June 13 and Palos Park, June 17-26 (Liljeblad); Eggers, June 27 (Wolcott) ; Elgin, June 4 (Bristol); Algonquin, June 10 (I.S.N.H.S.).

Indiana : Marshall County, May 11 (Blatchley).

Iowa: McGregor, July 15 (Wolcott).

Maine : Monmouth, June 16, July 14 (Frost).

Manitoba: Aweme, July 17-19 (Criddle).

Maryland: Plummers Island, July 30 (Hubbard and Schwarz, U.S.N.M.).

Massachusetts : Sherborn, June 13 (Frost).

Missouri: Atherton, May 25 (Adams, K.U.).

Montana: Missoula (Adams).

North Dakota: Devils Lake, July 28 and Stump Lake, July 24, Nelson County (Hubbell).

Ontario: Toronto, June 13 (Crew coll., C.U.).

Pennsylvania: Cumberland, July 10, Inglenook, June 15 and Hummelstown, May 31 (Knull) and Montgomery and Chester counties, May 31 to June 20. 


\section{Mordellistena militaris Leconte}

Mordellistena militaris Leconte, 1862, p 49, middle and northern states. J B. Smith, 188ः, pp. 86, 92. Blatchley, 1910, p. 1319.

Description.-Posterior tibiae with two oblique, parallel ridges on outer face, subapical not included; first segment of posterior tarsi with three ridges, second with two.

"Black, head and humeral spot of elytra reddish yellow; anterior feet yellow, hind feet black, varied with testaceous, .09. Middle and Southern States"' (Leconte).

REmarks.-Three specimens, two from Southern Pines, North Carolina, and one from Flatbush, Long Island, agree very closely with the above description, differing only slightly in the color of the thorax. In view of Leconte's description of the "head and humeral spot of elytra reddish-yellow," I cannot see any reason for Smith's note (1882: 92) that "this species will probably turn out to be a variety of Mordellistena scapularis Say," which has the head black and is twice as long as militaris.

The specimens before me have the ridges as described above. Head reddish yellow, a little dusky between eyes in female; antennae fusco-ferruginous; a little lighter at base; pronotum in male with apical half reddish yellow, and basal half blackish, in female with only a trace of reddish yellow at apex, remainder black; elytra black with a reddish yellow humeral spot; pubescence brownish yellow; underside black; front legs pale testaceous; hind legs with femora black and tibiae and tarsi testaceous; antennae filiform; third and fourth segments about equal in length; fifth one-fourth longer than fourth; last segment of maxillary palpi short, scalene triangular, somewhat as in $M$. pallipes.

The female agrees very closely with Leconte's description. The supposed type or first specimen in the Leconte collection, now in the Museum of Comparative Zoology, also agrees with the above description. Numbers one, two, three, and five in the Leconte collection are militaris, the other four are not. This species seems to be rather rare.

Previous ReCords.-Middle and northern states (Leconte); Cincinnati, Ohio (Dury).

Material Examined.-New York: Flatbush, Long Island, July 7 (Zabriskie, A.M.N.H.).

North Carolina: Southern Pines, June 23 (Manee).

\section{Mordellistena argenteola, new species}

$$
\text { (Pl. IV, Fig. 16) }
$$

TrPe.-From Sevier Lake, Utah. A male, collected July 3 by H. F. Wickham; in the Museum of Zoology, University of Michigan (Liljeblad coll.). 
Allotype.-A female, same data as type, in the collection of the Museum of Zoology, University of Michigan (Liljeblad coll.).

Paratypes.-Two, same data as type. One, Provo, Utah, collected by H. F. Wickham. Forty, Globe, Arizona, July, collected by D. K. Duncan. Paratypes in the collections of H. F. Wickham and of the Museum of Zoology, University of Michigan.

Description.-Posterior tibiae in male with two short ridges, in female with rudiment of a third ridge, subapical not included; first segment of posterior tarsi in male with three ridges, in female with rudiment of a fourth ridge; second segment with two short ridges in both sexes; all ridges somewhat well marked.

Linear; head flavo-testaceous, with a somewhat darker cloud at middle, which is nearly black in some specimens, densely covered with sericeo-argenteous pubescence; antennae with four basal segments testaceous; fifth to eleventh segments fuscous, densely covered with setae; maxillary palpi testaceous, a little darker in female; thorax flavo-testaceous, much darker on basal half, especially in female, and with dense sericeo-argenteous pubescence; scutellum argenteous; elytra with ground color seemingly black, and with a broad vitta of dense sericeo-argenteous pubescence from base to near apex, broadest at base; suture and sides with black or brownish black pubescence, connected at apex; underside except prosternum at base, black, densely covered with grayish pubescence; anterior legs testaceous; middle legs more or less fuscous; posterior legs black; anal style black.

Head rather large, one-fourth narrower than thorax, finely punctured; antennae with first four segments narrow, fifth to tenth broader and very slightly serrate; first and second segments parallel; second a little shorter than first; third and fourth triangular, equal in length, third narrower at base; fifth triangular, one-fourth longer than fourth and much broader at apex; sixth to tenth subparallel, each a little shorter than fifth; eleventh a little longer than tenth, oval; maxillary palpi scalene triangular, with inner angles more sharply defined in male than in female; eyes coarsely granulated, in male with a slight emargination in front.

Pronotum very little broader than long, a little broader than elytra at base; its sides rounded, finely punctured; its base rounded in front of scutellum; scutellum very small, triangular, rounded at tip.

Elytra parallel to apical fourth, then converging to tip, finely punctured; underside finely punctured; abdomen with last segment longer in male than in female; anterior femora in male with long setae on inner side, finely pubescent in female. Anal style very short.

Length: to apices of elytra, 2.5-3.5 mm.; to tip of anal style, 3.25$4.25 \mathrm{~mm}$.

Remarks.-This species differs from other members of the Mordellistenae 
mainly in the color pattern, the head and thorax being partly flavo-testaceous and the elytra black, with a broad, shining, silvery gray vitta. It is also recognizable by the ridges on the posterior legs.

\section{Mordellistena syntaenia Liljeblad}

(Pl. IV, Fig. 17)

Mordellistena syntaenia Liljeblad, 1921, p. 184, Massachusetts.

DesCRIPTION.-Posterior tibiae in male with two short, parallel ridges on outer face, in female with three such ridges, subapical not included; first segment of posterior tarsi with three ridges and second with two in both sexes; all ridges short and somewhat indistinct.

Body linear; head black, with rather long and coarse sericeo-cinereous pubescence; antennae black, with four basal segments fusco-ferruginous; mouth parts fusco-ferruginous; prothorax black, with long, coarse, sericeous pubescence; elytra black, each elytron with two sericeo-cinereous stripes or vittae, one near suture, widening' basally and there dividing to enclose a narrow black streak in the center, other vitta narrow, near margin, connected with first at base and apex, enclosing a broad black space on disk, and leaving suture and lateral margin black; undersurfaces black, covered with cinereous pubescence; anterior legs ferruginous, becoming fuscous on apex of femora and tarsi; middle legs a little darker; posterior legs black, becoming ferruginous on tibial spurs.

Head a little narrower than thorax, closely and finely punctured; antennae filiform, reaching nearly to base of thorax; first and second segments equal in length; third a little shorter than second; fourth one-third longer and a little broader than third; fifth one-third longer and a little broader than fourth; sixth to tenth about equal in length; eleventh longer than tenth; apical segment of maxillary palpi securiform; eyes moderately large, finely granulated and hairy.

Pronotum about as broad as long in male, a little broader in female; its base as broad as elytra, broadest at middle; its sides evenly rounded and slightly converging to apex; basal lobe truncate or very slightly emarginate at middle in front of scutellum.

Elytra widest at middle and slightly tapering to apex, finely and closely punctured. Inner edges of femora and tibiae of anterior legs bearing long erect setae in male, only fine hairs in female; inner spur of posterior legs one-third longer than outer. Anal style long and slender.

Length : to apices of elytra, $3 \mathrm{~mm}$.; to tip of anal style, $4 \mathrm{~mm}$.

REMarks.-This species is unlike all other North American forms of Mordellistena, being readily distinguishable by the elytral markings and the ferruginous anterior legs. The ridges on the posterior legs vary much in size, being small and faintly indicated in many specimens. Some examples have slight indications of rudimentary ridges. 
In the Leconte collection in the Museum of Comparative Zoology the supposed type or first specimen of Mordellistena convicta Leconte belongs to the present species. I am of the opinion, however, that Leconte did not have a specimen of syntaenia before him when he described convicta. (See note under $M$. convicta.)

The type of the above species is in the collection of the Museum of Zoology, University of Michigan (Liljeblad coll.).

Previous Records.-Duxbury, Massachusetts, June 27, Sherborn, Natick, and Southboro, Massachusetts, May 25 to June 22, and Dummerston, Vermont, July 14 (Frost).

Material examined.-Massachusetts : Kopkinton, May 25, on Crataegus (Frost) and Ellis (Edwards coll., A.M.N.H.).

New Hampshire: Rumney, June 17 to 21 (Darlington).

\section{Mordellistena egregia, new species}

(Pl. IV, Fig. 18)

Trpe.-From Mariposa County, California. A male, collected June 13, 1914, by F. W. Nunenmacher; in the Museum of Zoology, University of Michigan (Liljeblad coll.).

Allotype.-Same locality, Jume 5, collected by F. W. Nunenmacher.

Description.-Posterior tibiae with two strongly marked, parallel, oblique ridges reaching middle, subapical not included; first segment of posterior tarsi with three small ridges, second with two.

Cuneiform; head ferruginous, with vertex black, sparsely covered with yellowish gray pubescence; antennae with four basal segments rufous, remainder fuscous; palpi fusco-ferruginous; thorax black, with a rufous spot on each side extending from apical margin to near middle, covered somewhat sparsely with yellowish gray pubescence, densest at sides; elytra rufous, with suture narrowly black and lateral margin black at middle; underside black, with metasternum more or less ferruginous; abdomen densely covered with silky yellowish hairs; all legs more or less ferruginous, posterior legs fuscoferruginous in female; anal style ferruginous in male, nearly black in female.

Head moderately large; surface minutely aciculate and with very fine punctures; eyes rather small, finely granulated, hairy; antennae long, last two segments reaching below base of thorax, more strongly serrate in female than in male, third segment triangular, fourth seg'ment nearly twice as long as third; fifth one-fifth shorter than fourth; sixth to tenth about equal in length; last segment of maxillary palpi elongate.

Pronotum one-third broader than long; surface minutely aciculate and with fine punctures; basal angles subacute; apical angles obtusely rounded; basal lobe broadly rounded at middle in front of scutellum; scutellum triangular, somewhat broadly rounded at tip. 
Elytra attenuate; apex rounded, with very fine margin. Anal style long and slender.

Length : to apices of elytra, $3.75 \mathrm{~mm}$; to tip of anal style, $4.75 \mathrm{~mm}$.

REMARKs.-This rather prettily marked species somewhat resembles several others in the elytral markings, but is easily recognized by the color of the head and thorax and by the tibial and tarsal ridges. The elytra perhaps has an orange rather than a ferruginous cast in the male, and the female has a darker shade on the apical half of the elytra which, in turn, are much broader. The single female examined also has a rudimentary third ridge on the left tibia and a rudiment of a fourth ridge on the first segment of the left hind tarsus, but these ridges can only be considered aberrant structures.

\section{Mordellistena comata (Leconte)}

(PI. IV, Fig. 19)

Mordella comata Leconte, 1858, p. 75, California.

Mordellistena comata Leconte, 1862, p. 49. J. B. Smith, 1882, pp. 87, 92; 1883, p. 4. Blatchley, 1910, pp. 1318, 1319.

Description.-Posterior tibiae with two small, equal, oblique ridg'es, subapical not included, rarely with a rudiment of a third ridge; first segment with three, sometimes four, second with two ridges, upper sometimes rudimentary.

Nearly parallel, especially in male sex; head, thorax, palpi, four basal segments of antennae, and anterior leg's testaceous, posterior leg's darker; thorax in some females a little dark near base; surface covered with fine, silky yellowish pubescence; apical segments of antennae dark; elytra black, densely covered with rather coarse, silvery, iridescent pubescence, in some specimens unusually fine; underside somewhat dark with bluish reflections, a little testaceous on pectus; pubescence same as above, dense but finer; anal style a little dark.

Head a little narrower than thorax, with surface very minutely aciculate; eyes moderately large, rather coarsely granulated with sparse seta-like hairs and with a small emargination behind antennae; last segment of maxillary palpi scalene with inner side nearly as long as apical; antennae subserrate, reaching to about base of thorax and with segments nearly subequal in length; fifth segment the broadest; sixth to eleventh slightly diminishing in width.

Pronotum a little broader than elytra at base, evenly curved to apex; hind angles nearly acute; basal lobe, in front of scutellum, broad, nearly truncate at middle; surface finely aciculate and punctured. Scutellum small, rounded at apex.

Elytra nearly parallel to near apex; surface like pronotum but with punctures somewhat raised; undersurface finely punctured; anal style rather short, pointed. Anterior femora and tibiae of male more curved, inner side set with setae; those of female straight and with fine pubescence. 
Length : to apices of elytra, $2.75-3.5 \mathrm{~mm}$.; to tip of anal style, $3.25-4 \mathrm{~mm}$.

REMARKs.-This species seems to be somewhat rare. It is very frequently considered to be the same as Mordellistena cervicalis, picicornis, or auricoma, but the dense, silky, metallic, silvery pubescence on the elytra and undersurface, and the testaceous or rufo-testaceous head and thorax should be sufficient to identify it; the other species have black elytra. The ground color of the elytra in some specimens, especially those from Texas, seems to have a reddish yellow cast, with very fine, silky pubescence, which gives the insect a very beautiful shading. There is only one specimen of comata in the Leconte collection. This is the supposed type or first specimen in the series and is a female, having a golden tag, which indicates California. This specimen is somewhat faded and has the pubescence matted down, but it is readily separable from specimens placed near it, cervicalis or picicornis.

According to J. B. Smith's synopsis (1882: 92) picicornis, cervicalis, and auricoma are identical with comata, for the expressed reason that the color of the head and thorax and, more particularly, the color of the pubescence are not safe guides in this genus. I am of the opinion, however, that both color and pubescence must be taken into consideration for the separation of the species as well as of the varieties. Among a thousand specimens of cervicalis, picicornis, and auricoma from the northern, central, or eastern states, collected and identified, not one has yet been found that in color can be said to approach the western or southern comata.

Previous Records.-Fort Yuma, California (Leconte); and Florida (J. B. Smith).

Material examined.-Arizona: Black Dike Prospect, Sierritas, July 26-29, San Xavier, near Tucson, July 24, Tucson, August 14-17, Palo Alto, July 29-30, and Kits Peak, Rincon, Baboquivari Mountain, August 1-4 (A.M.N.H.).

Texas: Columbus, July 13 to September 6 (Hubbard and Schwarz, U.S.N.M.).

\section{Mordellistena cervicalis Leconte}

(Pl. IV, Fig. 20)

Mordellistena cervicalis Leconte, 1862, p. 49, New York.

Mordellistena picicornis Leconte, 1862, p. 49.

Mordellistena auricoma Helmuth, 1865, p. 96.

Mordellistena comata, J. B. Smith (nec Leconte), 1882, pp. 87, 92.

Mordellistena exilis Liljeblad, 1917, p. 10.

Description.-Posterior tibiae with two parallel, oblique ridges on outer face, subapical not included; first segment of posterior tarsi with three or four ridges, second with two. In some specimens there may be a third rudimentary ridge on the tibiae.

Elongate parallel; head reddish yellow with a large black spot or cloud at base, covered with grayish white pubescence; antennae with four basal 
segments pale; fifth to eleventh segments black; palpi pale; prothorax ferruginous with narrow basal margin and a black spot or line at base, latter more strongly marked in female, covered with grayish or brownish pubescence, somewhat iridescent on dark part; elytra black with pubescence like thorax; undersurface black, pubescence like that of thorax; anterior and middle legs pale, and posterior legs black in male, all legs usually black in female; anal style black, with silvery pubescence at base.

Head large, minutely aciculate and punctured; antennae subfiliform, reaching a little below thorax; first and second segments rather large; third a little shorter than fourth, which also is a little shorter than fifth; fifth longest but fifth to tenth each about equal in length; all segments with sides somewhat parallel; last segment of maxillary palpi scalene triangular; eyes moderately granulated, hairy.

Pronotum very little broader than long, finely aciculate and punctured; basal angles obtuse; basal lobe broadly rounded in front of scutellum.

Elytra with sides parallel to near apex; surface aciculate and with raised punctures, stronger at base; anal style rather long and pointed, less so in female.

Length: to apices of elytra, $2.5 \mathrm{~mm}$. in male, $3.75 \mathrm{~mm}$. in female; to tip of anal style, $3 \mathrm{~mm}$. in male, 4.75 in female.

REMARKS.-This very common species is in nearly every collection under the name comata. The ridges vary a little, as a rudimentary ridge may be found in some specimens. Mordellistena picicornis, cervicalis, and auricoma were placed by J. B. Smith in the synonymy of comata (see note under comata). It appears, however, that cervicalis is the male and picicornis is the female of the same species and that auricoma and picicornis are male and female of the same species. I propose to use the male, cervicalis, as the type of the species. The color of the elytra and undersurface is entirely black, with the pubescence a little reddish or reddish brown, whereas in comata it is dense silvery, so dense that the ground color of the elytra can scarcely be distinguished.

Previous RECords.-Central states and New York (Leconte); Illinois (Helmuth) ; Ames, Iowa (Wickham) ; Iowa City, Iowa (Wickham) ; Ridgeway, Ontario, Canada (Alva H. Kilman); southwestern Pennsylvania (Hamilton); Indiana, southern two-thirds of state, May 27 to June 21 (Blatchley).

Material examined.-Connecticut: Sound Beach, July 23 (A.M.N.H.).

District of Columbia: Washington, June 11 (McAtee, U.S.N.M.).

Illinois : Edgebrook, Bowmansville, Fort Sheridan, Palos Park, and Willow Springs, May to September (Gerhard, Wolcott, and Liljeblad); Algonquin, June 4 (Mason coll., I.U.).

Indiana: Hessville and Miller, July-Aug'ust (Liljeblad). 
Kansas: Douglas County, June 24 (Hoffman, K.U.).

Kentucky : no locality (I.U.).

Maine: Wales, August 2 (Frost).

Manitoba: Aweme (Criddle).

Maryland : Kensington, July 4 (Knab, U.S.N.M.).

Massachusetts : Chatham, July 14, Malden, August 12, Framingham, September 9, Sherborn, August 4-28, Berlin, August 8 (Frost) ; Springfield, May 21 (Knab, U.S.N.M.).

Michigan : Detroit, September 1 (Hubbell, U.M.).

Nebraska: Malcolm, July 24 (Oertel).

New Hampshire: Mount Washington, July 4 (Frost).

New Jersey: Phillipsburg, June 14 (J. W. Green); Anglesia, July 2 (J. W. Green) ; Lakehurst, May 31 (A.M.N.H.).

New York: Middletown, July 2-20 (Spooner, C.U.) ; Rhinebeck, July 27 (Crosby, C.U.) ; Friville, July 4, and Ellis, June 13 (C.U.) ; Woodwardia Bog, Thomkins County (C.U.) ; Ithaca, June 13-22 (Dietrich) ; Pearl River, June 21 (A.M.N.H.) ; Flatbush, Long Island, July 25 (U.S.N.M.).

North Carolina: Southern Pines (Manee).

Ohio: Kent, September (Wendellke, C.U.).

Ontario: Toronto (C.U.).

Pennsylvania: Pocono Lake, August 14 (J. W. Green).

Virginia: Great Falls, June 19 (Knab, U.S.N.M.) ; Fredericksburg, June 6 to July 21 (Richardson) ; Rosslyn, July 4 (Knab, U.S.N.M.).

\section{Mordellistena indistincta Smith}

Mordellistena indistincta Smith, 1882, pp. 87, 93, New York.

\section{DESCRIPTION. -}

Hind tibiae with two oblique ridges on the outer face. Ridges parallel, equal. First joint of hind tarsi with three, second with two ridges.

Rufo-piceous; pubescence dense brown scriceous; elytra darker, with a large indistinct paler basal spot; legs and antennae more rufous. 3-4 mm. New York.

Easily known by the pale color and the indistinet basal spot on elytra; it seems to eonnect the black species with the following. Seventeen specimens, Adirondack Mts., N. Y.; my collection. (Smith)

REMARKS.-I have not been able to locate the type, nor to find any specimen that agrees with the description.

\section{Mordellistena aspersa (Melsheimer)}

(Pl. IV, Fig. 21)

Mordella aspersa Melsheumer, 1846, p. 314, Pennsylvania.

Mordellistena aspersa, Leconte, 1862, p. 49. J. B. Smith, 1882, pp. 87, 93. Blatehley, 1910, pp. 1318, 1319.

Description.-Melsheimer's description is as follows:

Blackish; elytra obsoletely specked with white; size as the preceding (M. pustulata). 1. L. long. Pennsylvania. 
Blackish with ashy pubescence; antennae hardly as long as the thorax, slightly serrate, entirely black; mouth and palpi piceous; elytra black, passing into dark reddishbrown, obsoletely sprinkled with numerous white points and irregular small spots; all the feet and underside black; ventral style moderate. Quite distinct from the preceding species (M. pustulata).

REMARKS.-Leconte (1862: 49) added the following note concerning the type: "The pubescence of this species is described by Dr. Melsheimer as being mottled, but the type furnished by him, on being carefully cleaned and remounted, shows a uniformly diffused covering of brownish gray hair."

From the above descriptions and notes, I am convinced that more than one species has commonly been included under this name and that the true aspersa is a small beetle not more than $3 \mathrm{~mm}$. long and almost entirely black.

Posterior tibiae with two parallel, oblique ridges and rudiment of a third ridge, this third ridge sometimes rather long, but very narrow and usually more oblique than the others, subapical not included; first segment of posterior tarsi with three and second with two ridges.

Linear, narrow; ground color entirely black except mentum, palpi, and two or three basal segments of antennae, which are piceous brown, almost black; surface covered with brownish gray pubescence.

Head rather large, nearly as broad as elytra at base, minutely punctured; surface very finely aciculate; eyes not quite reaching occiput, somewhat coarsely granulated and hairy; antennae filiform, as long as head and thorax together; fifth to tenth segments very slightly serrate; third and fourth segments about equal in length, triangular, fourth a little broader; fifth elongate, as long as third and fourth combined, or nearly so; sixth to tenth elongate, each nearly as long as fifth; all segments very hairy; last segment of maxillary palpi scalene triangular, apical side longer than inner.

Pronotum about as broad as long, a little broader than elytra at base; surface very finely aciculate and with fine, somewhat raised punctures; basal lobe broadly rounded in front of scutellum; basal angles subacute; scutellum small, rounded at apex.

Elytra nearly parallel to near apex, surface reticulate, with rather strongly raised punctures; apex rounded; anal style rather long, pointed. Inner side of femora and tibiae with long setae in male; in female, with fine pubescence; also antennal segments five to ten are more coarsely serrate in male.

Length : to apices of elytra, 2-2.5 mm.; to tip of anal style, $2.5-3 \mathrm{~mm}$.

This species is readily recognized by its small size, dark color, and brownish gray pubescence. It is very common. The larvae have been found boring in the pithy walls of the gall formation of the Trupaneid fly Eurosta solidaginis, two larvae sometimes being found in one gall formation. I have examined specimens from nearly every state in the Union. 


\section{Mordellistena rubrifascia, new species}

TyPE.-From Edgebrook, Illinois. A male, June 28, collected by Emil Liljeblad ; in the Museum of Zoology, University of Michigan (Liljeblad coll.).

Allotype.-Same data as type.

Paratypes.-Same locality as type, June 14-28; Hessville, Indiana, May 30, and Columbus, Ohio, July 21, all collected by Emil Liljeblad.

DESCRIPTION.-Posterior tibiae with two oblique, parallel, equal ridges, subapical not included; first segment of posterior tarsi with three, second with two ridges.

Elongate, parallel; males largely black; front of head rufo-testaceous; four basal segments of antennae, maxillary palpi, anterior legs, femora and tibiae of middle legs more or less testaceous, covered with sericeo-cinereous pubescence, denser and longer on elytra; female similar in color but with antennae more or less testaceous throughout and with middle legs black.

Head large, nearly as broad as elytra at base, minutely aciculate and finely punctured; eyes finely granulated, hairy; antennae short, reaching to near base of thorax, filiform; fifth to tenth segments very slightly serrate; third and fourth segments short, the two combined about as long as fifth; sixth to tenth subequal in length, each a little shorter than fifth; last segment of maxillary palpi elongate, scalene triangular, with apical side a little shorter than inner.

Pronotum one-fifth broader than long; surface aciculate, with fine raised punctures; basal angle obtuse, apical angle broadly rounded; base broadly rounded at middle in front of scutellum; scutellum somewhat triangular, rounded at tip.

Elytra nearly parallel to near apex in male, broader at middle in female; surface with more strongly raised punctures; apex oblique. Anal style long and slender, a little broader in female. Anterior femora and tibiae, in male, with long hairs on inner side.

Leng.th : to apices of elytra, $2.75-3 \mathrm{~mm}$.; to tip of anal style, $3.5-3.75 \mathrm{~mm}$.

REMARKS.-This species is readily distinguished from the other species most nearly allied to Mordellistena aspersa by the filiform antennae, the color of the head and anterior legs, and the form and pale coloration of the maxillary palpi. Ten specimens have been examined.

\section{Mordellistena rufilabris, new species}

(Pl. IV, Fig. 22)

Trpe.-From False Bay, California. A male, collected on June 11 by C. L. Hubbs; in the Museum of Zoology, University of Michigan (Liljeblad coll.).

Allotype.-A female, same data as type.

PARATyPes.-Five, same data as type. 
Description.-Posterior tibiae with two parallel, oblique ridges, subapical not included; first segment of posterior tarsi with three, second with two ridges.

Subcuneate; black with front part of head rufous in both sexes; vertex black; thorax in male black with a certain amount of rufous suffusion, in female entirely black; four basal seginents of antennae dull rufous, remaining segments black; palpi dull rufous; anterior and middle femora more or less rufous; tibiae, tarsi, and posterior leg's black in both sexes, covered with rather long, reddish brown pubescence.

Head rather large, minutely aciculate and finely punctured; eyes somewhat coarsely granulated, obliquely truncate in front, not hairy; antennae a little longer than head and thorax, subfiliform; fifth to tenth segments very feebly serrate; third and fourth segments narrow, subequal in length; fifth to tenth about equal in length, each one-fourth longer than fourth and much broader; each segment slightly diminishing in width from fifth to apex; last segment of maxillary palpi rather broad in male, more elongate in female, scalene triangular in shape.

Pronotum about one-fourth broader than long, much broader than elytra at base; basal angles obtuse; apical angle broadly rounded, base broadly rounded at middle in front of scutellum, somewhat subtruncate medially; surface aciculate and finely punctured; scutellum rather large, triangular, rounded at apex.

Elytra elongate, subparallel, at base a little narrower than thorax; surface reticulate and with fine punctures; apex rounded, without distinct margin but with fine spinules. Anal style comparatively short.

Length : to apices of elytra, $3 \mathrm{~mm}$; to tip of anal style, $4 \mathrm{~mm}$.

REMARKS.-This species somewhat resembles other species in the aspersa group, but it is readily recognized by the form of the antennae (of which the fifth segment is the broadest and the sixth to the eleventh are about equal in length and gradually decrease in width to the apex), by the broader maxillary palpi, and by the partly rufous thorax in the male.

\section{Mordellistena rubrilabris Helmuth}

(Pl. IV, Fig. 23)

Mordellistena rubrilabris Helmuth, 1864, p. 105, Illinois.

Description.-Posterior tibiae with two oblique, parallel, equal ridges, subapical not included; first segment of posterior tarsi with three, second with two ridges.

"Black, linear, mouth rufous, .13. Illinois" (Helmuth).

Linear ; black; front of head rufous; pronotum at apex sometimes more or less dull rufous; anterior legs dull rufous in male, black in female; remainder of insect entirely black, covered with fine, reddish brown or grayish pubescence. 
Head minutely aciculate and finely punctured; eyes somewhat coarsely granulated and with sparse hairs; antennae short, subfiliform, reaching nearly to base of thorax; third and fourth segments small, equal in length, each a little shorter than fifth; sixth to tenth subequal to fifth in length, very little longer than broad; eleventh oval; last segment of maxillary palpi elongate, nearly securiform.

Pronotum broader than elytra at base; basal angle subacute; apical angle broadly rounded; surface finely aciculate and punctured; basal lobe in front of scutellum broadly rounded, somewhat emarginate at middle; scutellum triangular, rounded at tip. Elytra a little broader at middle than at base; surface with fine raised punctures; apex rounded. Anal style rather short, pointed.

Length: to apices of elytra, $3-4 \mathrm{~mm}$; to tip of anal style, $3.75-4.25 \mathrm{~mm}$.

REMARKs.-This species, although placed in synonymy by J. B. Smith (1882: 93), is undoubtedly valid. It was described from Illinois. The type is no doubt destroyed, but I have specimens that agree with the description as far as it is given by Helmuth, and they do not agree with that for aspersa. The species is larger than aspersa is and is readily recognized by its size, antennae, and maxillary palpi. In the characters of ridges and general appearance it resembles other species in the aspersa group, but in size and color it is nearest to Mordellistena rufilabris.

\section{Mordellistena pullata, new species}

(Pl. IV, Fig. 24)

Type.-From Yuba County, California. A male, collected on June 19 by F. W. Nunenmacher; in the Museum of Zoology, University of Michigan (Liljeblad coll.).

Allotype.- $A$ female, same data as type.

Description.-Posterior tibiae with two equal, oblique, parallel ridges, subapical not included; first segment of posterior tarsi with three, second with two ridges.

Cuneiform; entirely black, covered with fine reddish brown pubescence. Head rather elongate, comparatively small, glabrous, with minute punctures; eyes moderately large, rather coarsely granulated, and with sparse hairs on lower margin; antennae short, subfiliform, reaching to near base of thorax; fifth to eleventh segments broadest; third and fourth segments nearly triangular and about equal in length but fourth a little broader; fifth to tenth much broader than third, each nearly as broad as long; last segment of maxillary palpi scalene triangular, inner side nearly as long as apical.

Pronotum one-third broader than long and one-fourth broader than elytra at base; surface minutely aciculate and with fine punctures; hind angles obtuse, apical angles broadly rounded; scutellum triangular, rounded at apex. 
Elytra with surface reticulate and rather deeply punctured; apex rounded and with a distinct margin; underside with close, raised punctures. Anal style long and very slender, pointed.

Length : to apices of elytra, $2.75 \mathrm{~mm}$.; to tip of anal style, $3 \mathrm{~mm}$.

REMARIKS.-This species is closely related to the other species in the aspersa group, but differs mainly in the form of the antennae and the shape of the maxillary palpi; it is entirely black and has the anal style very slender.

\section{Mordellistena nigella, new species}

TYPe.-From Pasadena, California. A male, collected on April 6, 1909, by C. A. Frost ; in the Museum of Zoology, University of Michigan (Liljeblad coll.).

Allotype.-A female, same data as type.

Paratypes.-Five, Pasadena, California, May, 1897, collected by Ralph Hopping ; in the Canadian National collection.

Description.-Posterior tibiae with two oblique ridges, subapical not included; first segment of posterior tarsi with three, second with two ridges.

Elongate, narrow; entirely black except mouth parts which are slightly tinged with reddish brown.

Head unusually large, nearly as broad as thorax; surface minutely aciculate and punctured; antennae filiform, hairy, longer than head and thorax; third segment shortest, triangular; fourth segment longer than third; fifth about one-fourth longer than fourth; sixth to tenth each a little shorter than fifth; eleventh longer than tenth and oval; last segment of maxillary palpi rather long, scalene triangular, with inner side less than one-half as long as apical side and about one-third as long as outer side; second segment very broad; eyes moderately large, hairy, not quite reaching occiput.

Pronotum one-third broader than long; sides when viewed from above apparently ending in a point at middle of head; basal angle obtuse; basal lobe at middle broadly rounded; surface minutely aciculate and punctured.

Elytra rather long, nearly parallel, a little narrower at base and as broad at middle as pronotum; surface reticulate and somewhat coarsely punctured; pubescence long and sparse, brownish gray; anal style long and narrow; female like male but with antennae shorter and segments more equal in length.

Length: to apices of elytra, $2.5 \mathrm{~mm}$.; to tip of anal style, $3.5 \mathrm{~mm}$.

REMARKs.-This addition to the confused aspersa group differs from the other species in the narrower elongate form and in the shape of the maxillary palpi, which, in the male, have the second segment very broad and the apical segment nearly in the form of an isosceles triangle, with the inner side less than half the length of the apical. 


\section{Mordellistena tosta Leconte}

Mordellistena tosta Leconte, 1862, p. 49, Georgia. J. B. Smith, 1882, pp. 87, 93.

DESCRIPTION.-Posterior tibiae with two, equal, parallel, oblique ridges on outer face, subapical ridge not included; first segment of posterior tarsi with three, second with two smaller ridges; all ridges well marked; in some specimens a rudimentary ridge on the tibiae.

Subcuneate; pale yellowish brown, except eight apical segments of antennae, apical third of elytra, and abdominal segments, which are more or less dusky; covered with sericeous yellow pubescence, more grayish and coarser on elytra.

Head comparatively large, minutely punctured; eyes rather coarsely granulated and with fine hairs; antennae long, filiform, or very slightly serrate; third segment shortest, one-fourth shorter than fourth; fifth to tenth about equal in length, each a little shorter than fourth; eleventh longer than tenth, pointed at tip; last segment of maxillary palpi scalene in male, more elongate securiform in female.

Pronotum one-fourth broader than long, broadest a little before base; basal angle subacute; basal lobe in front of scutellum broadly rounded, not very prominent; surface finely punctured; scutellum small, triangular, rounded at tip.

Elytra very little narrower than thorax at middle, slightly tapering to apex, and a little divergent at apical suture; surface finely punctured. Anal style long and slender, pointed.

Length : to apices of elytra, 3-3.5 mm.; to tip of anal style, $3.75-4.5 \mathrm{~mm}$.

REMARKS.-This species is not common anywhere. It may be readily recognized, after the ridges have been examined, by its pale coloration with the dusky appearance on the apical third of the elytra and on the abdominal segments. Some specimens, especially those from Illinois, have pale abdominal segments. The supposed type or first specimen of this species in the Leconte collection is a male; the pin label is brick-red, indicating the Gulf states. This specimen, however, does not exactly agree in color with the original description, which says "pale yellowish brown," while it is more reddish brown or castaneous, although the specimen may have turned darker with age.

Previous ReCords.--Georgia (Leconte); New York (Smith); southwestern Pennsylvania (Hamilton); Cincinnati, Ohio (Dury).

Material Examined.-Illinois: Edgebrook, June 10-14 (Liljeblad); Algonquin, June 10 (I.S.N.H.S.).

Kansas: Gray County, July 9 (K.U.) ; Hodgeman County, July 17 (K.U.).

Maine : Monmouth, July 18-30 (Frost).

Manitoba: Aweme, August 2-30 (Criddle). 
Massachusetts : Sherborn, August 22, Framingham, July 20, and Hopkinton, June 26 (Frost).

Michigan : Berrien County, June 26, July 9, and Huron County, June 17 (Hubbell).

New Jersey: Phillipsburg, July 19 (J. W. Green).

New York : Ithaca, July 12-21 (Groteclose, C.U.).

North Dakota: Devils Lake, July 28 (Hubbell).

Ohio: Cincinnati, June 26 (Soltau, U.S.N.M.).

Ontario : Toronto, July 1-11 (Crew coll., C.U.).

Pennsylvania: Pocono Lake, July 30 (J. W. Green) ; Jeannette, August (Knull) ; Harrisburg (bred specimens, reared from alder by Champlain).

Tennessee: Brunette County, February (Frost).

Texas: San Diego, June 29 (E. A. Schwarz, U.S.N.M.) and no locality (I.U.)

\section{Mordellistena pallens Fall}

Mordellistena pallens Fall, 1907, p. 255, New Mexico.

DESCRIPTION.-

Hind tibiae with two rather short oblique ridges, the upper slightly more oblique, and with a trace of a third ridge; first joint of hind tarsi with three ridges, the second with two.

Pale yellowish testaccous; abdomen infuscate, except at apex; antennae with outer joints dusky. Form slender, linear, pubescence pale yellow. Antennae slender, fourth joint four-fifths as long as the fifth, the latter evidently shorter than the third and fourth united. Terminal joints of maxillary palpi not very strongly dilated, about twice as long as wide, the outer edge shorter than the inner.

Length: $3.3 \mathrm{~cm}$.

Mesilla, July 31, at light. (Cockerell)

Closely allied to tosta, the type of which is entirely pale, the fourth joint of the antennae about two-thirds as long as the fifth, the latter as long as the two preceding united; the tibial ridges longer. (Fall)

I have not seen the type. A few specimens have been examined, however, that agree with the above description, especially one in the United States National Museum labeled "Mesilla, New Mexico, August 2 (Ckll.)," with the same locality and collector as the type. This specimen agrees well with the original description. The pubescence on the upper surface of the elytra is very fine and iridescent, and the eyes are large, rather coarsely granulated and hairy. It is, no doubt, very near tosta, but how close cannot be ascertained before a larger series of both sexes is examined. The supposed type of tosta is a male which, when examined, was found to be castaneous or light reddish brown with the underside darker (see note under tosta).

\section{Mordellistena inornata Smith}

Mordellistena inornata Smith, 1882, pp. 87, 93, Texas. 
DESCRIPTION.-

Hind tibiae with two oblique ridges on the outer face. Ridges parallel, equal. First joint of hind tarsi with four, second with three very oblique ridges. Tibiae with a rudiment of a third ridge; fulvous yellow. $3 \mathrm{~mm}$. Texas.

Like the preceding (tosta) in color, but distinct by the combination of tibial and tarsal ridges. One specimen, Texas; Coll. Dr. LeConte. (Smith)

Remarks.-With the exception of the ridges this species is seemingly very nearly allied to Mordellistena tosta. No specimen could be found in the Leconte collection, but there is one in the Belfrage collection from Texas, which may be the type. The color resembles that of tosta, but the ridges differ somewhat; the antennae could not be examined. Aside from this, only one specimen, from Arizona, has been seen that agrees with the above description.

\section{Mordellistena minuta Smith}

$$
\text { (Pl. V, Fig. 1) }
$$

Mordcllistena minuta Smith, 1882, pp. 87, 93, Georgia.

Posterior tibiae with two ridges, upper one longer and more oblique, nearly crossing outer face of tibiae, subapical ridge not included; first segment of posterior tarsi with two small, oblique, parallel ridges, and second segment with one small ridge.

Subcuneate; head in front reddish yellow, elsewhere black; antennae and palpi yellow; prothorax black; elytra black with two yellowish bands, one near base (interrupted at suture), other below middle; undersurface black except abdominal segments which, in some specimens, are somewhat lighter; legs more or less yellowish ; pubescence on thorax and elytra long and coarse.

Head shining, finely punctured; eyes finely granulated and hairy; antennae short, about $.75 \mathrm{~mm}$. long, not reaching middle of thorax; first and second segments large, each about as long as third and fourth combined; third and fourth segments very small ; fifth to tenth subequal in length; each one-third longer than fourth and much broader; eleventh a little longer than tenth, pointed at tip ; last segment of maxillary palpi elongate securiform, with inner side a little shorter than outer.

Pronotum about one-fourth broader than long with fine, somewhat raised punctures; basal angles acute; basal lobe in front of scutellum broadly rounded; scutellum triangular, rounded at tip.

Elytra nearly parallel to below middle; surface more coarsely punctured; apex narrowly rounded; undersurface with fine, raised punctures. Anal style rather long and very pointed.

Length : to apices of elytra, $1.5-1.75 \mathrm{~mm}$.; to tip of anal style, $2-2.5 \mathrm{~mm}$.

Remarks.-This is one of the smallest species of Mordellistena. It resembles $M$. trifasciata in the color of the elytra, but differs from it in the color of the head and thorax and in the much shorter antennae, with the 
third and fourth segments equal to the second in length. Although the type of this species has not been located, there is no doubt that the specimens from which the above description is taken are like the one Smith had before him.

Previous ReCord.-Georgia (Smith).

Material examined.-Arkansas: Fayetteville, May 3 (Knaus).

Florida: Dunedin, February 3 to June 3 (Blatchley).

Georgia: St. Catharine Island, June 19 (U.S.N.M.).

North Carolina: Southern Pines, June 5 (Manee).

\section{Mordellistena picilabris Helmuth}

(P. V, Fig. 2)

Mordellistena picilabris Helmuth, 1864, p. 105, Illinois. J. B. Smith, 1882, pp. 87, 93. Blatchley, 1910, p. 1320.

Description.-Posterior tibiae with two parallel ridges, the anterior one extending almost across the outer tibial face, subapical ridge not included; first segment of posterior tarsi with two ridges, second with one ridge.

"Black, pubescence grayish; mouth and basal joints of antennae piceous. .08. Illinois" (Helmuth).

Remarks.-Of this species I have seen only four specimens that nearly agree with Helmuth's description, differing but slightly from the color as given.

Helmuth's type is undoubtedly destroyed, and it is impossible to discover from the brief description what sex it may have been. The four specimens available for study are all of the male sex.

Linear; entirely black except four basal segments of antennae, palpi, and anterior legs, which are dark reddish testaceous, covered with fine, sericeous, reddish brown and grayish pubescence, more sericeous on head and thorax.

Head with surface minutely aciculate and punctured; eyes finely granulated and very sparsely hairy; antennae subfiliform or very slightly serrate, a little longer than head and thorax; third segment one-fourth shorter than fourth; fifth one-third longer than fourth, much broader; sixth to tenth subequal in length, each one-fifth shorter than fifth and diminishing in width to eleventh, which is oval; last segment of maxillary palpi somewhat scalene triangular.

Pronotum one-fourth broader than long, lateral margin nearly straight; basal and apical angles obtuse; basal lobe in front of scutellum broadly rounded; surface minutely aciculate and with fine punctures; scutellum small, triangular, rounded at tip.

Elytra nearly parallel to near apex, surface aciculate, more reticulate near base and with fine punctures; underside reticulate and more finely punctured on abdominal segments. Anal style long and slender.

Length: to apices of elytra, $2.5 \mathrm{~mm}$; to tip of anal style, $3.25 \mathrm{~mm}$. 
REMArks.-The type was recorded from Illinois and a neotype has now been selected from Palos Park, Illinois.

Previous records.-Illinois (Helmuth); Cincinnati, Ohio (Dury); Bellport, New York (Nicolay).

Material examined.-Illinois: Palos Park, June 25, 1916 (neotype, Liljeblad) ; Beverly Hills, June 15 (Liljeblad).

Maine : Paris, July 8 (Frost).

Massachusetts : Framingham, July 27 (Frost).

\section{Mordellistena minutalis, new species}

(Pl. V, Fig. 3)

Trpe.-From San Diego, California. A male, collected on June 12 by C. L. Hubbs ; in the Museum of Zoology, University of Michigan (Liljeblad coll.).

Allotype.-A female, same data as type.

Paratypes.-Twenty-three, same data as type.

Description.-Posterior tibiae with two parallel, oblique ridges, subapical not included, outer extending almost across outer face of tibiae; first segment of posterior tarsi with two ridges, second with one ridge.

Subcuneate: entirely black, with dense sericeous cinereous or reddish brown pubescence.

Head large; surface minutely aciculate and with fine raised punctures; eyes rather coarsely granulated, hairy; antennae filiform, short, slightly widened toward tip, beginning with third segment and reaching to base of thorax; second segment largest; third segment small, triangular, one-fifth shorter than fourth; fifth to tenth subequal, each a little longer than fourth; eleventh one-third longer than tenth, oval; last segment of maxillary palpi elongate, securiform, slightly rounded on inner angle.

Pronotum one-fourth broader than long; surface minutely aciculate and with fine raised punctures; basal and apical angles obtuse; basal lobe at middle in front of scutellum broad, very slightly emarginated at middle; scutellum small, triangular, rounded at tip.

Elytra nearly parallel to near apex, a little narrower at base than pronotum; surface aciculate and with fine, raised punctures; apex rounded, with a fine margin; underside with fine, raised punctures. Anal style long, comparatively stout.

Length : to apices of elytra, $1.75-2.25 \mathrm{~mm}$.; to tip of anal style, $2-3 \mathrm{~mm}$.

Remarks.-This species, on superficial examination, resembles Mordellistena vilis Leconte, but the ridges on the posterior tibiae will readily separate it from that species. Furthermore, it is more cuneate and somewhat shorter, the antennae are shorter, and the eyes are more elongated. It also resembles Mordellistena nigricans Melsheimer in the matter of ridges, but not in size, color, and antennae. 


\section{Mordellistena infima Leconte}

(Pl. V, Fig. 4)

Mordellistena infima Leconte, 1862, p. 49, South Carolina. J. B. Smith, 1882, pp. 87,

93. Blatchley, 1910, p. 1320.

Description.-Posterior tibiae with two ridges, upper long, entirely crossing outer face of tibiae and very oblique, subapical not included; first segment of posterior tarsi with three short oblique ridges and second with two.

Subcuneate; entirely black, except four basal segments of antennae and palpi, which are dark reddish brown; upper surface covered with cinereous pubescence; elytra with three bands formed of long, grayish pubescence, one at base, somewhat connected along suture with a larger band at middle and one one-fourth from apex.

Head moderately large, with minute punctures; eyes finely granulated and with very short hairs on outer edge; antennae long and narrow, somewhat filiform, longer than head and thorax and with three apical segments reaching beyond thorax; fifth to seventh segments slightly serrate; third segment one-fourth shorter than fourth, fifth one-third longer than fourth; sixth to tenth subequal in length; fifth broadest and, from this to tenth, each segment slightly decreases in width; all segments covered with dense liairs; last segment of maxillary palpi scalene triangular with apical side longer than inner.

Pronotum about as long as broad; surface reticulate and with fine punctures; basal angles nearly acute; basal lobe in front of scutellum rather broad, truncate at middle; scutellum broadly triangular.

Elytra nearly parallel to beyond middle; apex rounded, with distinct margin; surface reticulate and with fine, slightly raised punctures; anal style long and very slender, pointed; female similar to male, but with last abdominal segment shorter.

Length : to apices of elytra, 2-2.5 mm.; to tip of anal style, $2.75-3.5 \mathrm{~mm}$.

REMARKS.-This small, almost entirely black species was described by Leconte from South Carolina, although J. B. Smith, in his synopsis, stated "South California." The above description agrees with the supposed type or first specimen (which bears a brick-red label, indicating the Gulf states) now in the Museum of Comparative Zoology. It is very readily distinguished from other black forms by the tibial ridges, by the three heavily pubescent gray bands on the elytra, and by the form of the antennae and maxillary palpi. Two specimens have rather long grayish pubescence on the apex of the elytra, but there is not enough difference exhibited to warrant their description as a new species. Comparatively few specimens have been seen by me. The species appears from April to August.

Previous records.-South Carolina (Leconte); southern California ? (Smith); Cincinnati, Ohio (Dury). 
Material examined.-Alabama: Langdale, Chamber County (H. H. Stmith); Oak Grove, June 11 (Soltau, U.S.N.M.).

Florida : Orlando, April 29 (D. M. Long) ; Crescent City, April 24 (VanDuzee, A.M.N.H.).

Illinois: Springfield, July 4 (Hart, I.U.).

Maine : Paris and Wales, July 9-10 (Frost).

Manitoba: Aweme, August 27 (Criddle).

Maryland: Breton Bay, July 13 (Barber, U.S.N.M.).

Massachusetts : Framingham, June 1, and Southboro, June 5 (Frost).

Michigan: Washtenaw County, July 26 (Hatch) ; Berrien County, July 9 (Hubbell).

New Hampshire: Rumney, July 25, August 3 (Darlington).

New Jersey : Hopatcong (Palm, A.M.N.H.).

New York: Whiteface Mountains, August 22-24 (C.U.) ; Ithaca, August 3 (C.U.).

Ohio: Buckeye Lake, July 15 (Liljeblad).

Pennsylvania: Woolrich, May 25 (Knull).

\section{Mordellistena andreae Leconte}

(Pl. V, Figs. 5 and 6)

Mordellistena andreae Leconte, 1862, p. 50, central states, Georgia. J. B. Smith, 1882, pp. 87, 94. Blatchley, 1910, p. 1320.

Mordellistena grammica Leconte, 1862, p. 50. J. B. Smith, 1882, pp. 87, 94.

Description.-Posterior tibiae with two oblique ridges, subapical not included, anterior ridge more oblique, extending entirely across outer face of tibiae; first segment of posterior tarsi with three, second with two ridges.

Elongate; male with head, antennae, palpi, and legs yellowish; thorax yellowish; elytra yellowish with base, suture, apex, and a large oblong marginal or nearly submarginal spot at middle black; underside yellow, with abdomen more or less dark; posterior tibial spurs yellow; upper surface with yellowish pubescence; female with head black except a space in front of antennae which is yellowish; thorax black; underside black except base of coxal plate which is ferruginous or yellowish; rest like male; anal style dark.

Head comparatively large, minutely aciculate and finely punctured; antennae rather long, nearly filiform, reaching a little below thorax; third segment very little longer than fourth; fifth about as long as third and fourth combined; last segment of maxillary palpi triangular, outer side shortest; eyes moderately granulated, hairy, and with shallow emargination behind antennae.

Pronotum one-fourth broader than long, broadest at middle; hind angles obtuse; surface minutely aciculate and punctured. Elytra at base a little 
narrower than pronotum; sides at middle very little broader than at base, slightly acuminate to apex, which is rounded; surface reticulate and with fine punctures; anal style rather long and pointed.

Length : to apices of elytra, 2-3 mm.; to tip of anal style, $2.75-4 \mathrm{~mm}$.

REMARKS.-This species is now composed of a combination of grammica (male) and andreae (female), as is discussed in the notes that follow. It is readily recognized by the yellow thorax of the male and the black one of the female, and by the large, elongate, black marginal or submarginal spot on the elytra. Leconte did not recognize the color difference of the sexes; therefore, it has been necessary to combine his two forms into one. The types, now in the Museum of Comparative Zoology, have been examined by me and found to agree with the above description. The form is no doubt very rare, as only four specimens besides the type have been available for study.

Mordellistena andreae, grammica, ancilla, varians, and ustulata form a compact group and are very difficult to separate by the short descriptions and the figures given by previous writers. J. B. Smith, in his synopsis (1882: 94) said about these five names: "I am certain that there are two species more than there is any necessity for, described; but I have not unfortunately, a series large enough to prove it." Blatchley, in his notes under Mordellistena grammica (1910: 1321), included ustulata as a variation of that species. He also mentioned a specimen of varians, which seems to form a connecting link between that species and grammica.

From my observations of Leconte's types and type material of the various species mentioned above, now in the Museum of Comparative Zoology, it appears that the first specimen of $M$. andreae Leconte differs from the first specimen of $M$. grammica Leconte only in the color of the head and thorax, which are black in andreae and yellow in grammica. M. ancilla Leconte differs from $M$. andreae by having the head and thorax less dark and with a little ferruginous color. $M$. varians Leconte has the basal half of the thorax black, the underside nearly black, and the remainder as in ancilla. M. ustulata Leconte has the head and thorax ferruginous and the underside black except the coxal plate; otherwise it is like varians.

After a careful examination of fifty-seven specimens, only two females resemble the type of andreae, and two, both of which are males, are like grammica. Eight males agree very closely with the description of grammica but not with the type, although they vary in the marginal and apical marking's. Ten specimens are very close to varians, and ten are somewhat like ustulata, judging by the color of the underside. Only one specimen in the lot can be said to resemble ancilla, and this is between andreae and grammica.

What makes the validity of these species still more questionable is the 
fact that among seven specimens from Fredericksburg, Virginia, all collected on the same date, there are three of these named forms represented, and among eleven specimens from Langdale, Alabama, presumably collected on one date, four of the species are present.

From this association there can be no doubt that these five forms are very closely related and I believe that they should be considered as a single species. The color differences are so great, however, that I propose to recognize several varieties by name. The specimens with sharp distinct markings on the elytra are held to be the typical variety, to which the name Mordellistena andreae Leconte is applicable. It is believed that the first specimen in the Leconte collection under the name grammica, a male, supposed to be the type, should be considered as a synonym of this variety. This, in every respect except the color of the head and thorax, is like the type of $M$. andreae which, in turn, is a female. $M$. ancilla as the female and $M$. varians as the male can be regarded merely as a variety of andreae, ancilla having line priority. M. ustulata, of which both sexes are nearly alike, also should be considered as a variety of andreae.

Previous Reconds.-Middle states and Georgia (Leconte).

Material examined.-Alabama: Langdale, Chambers County (H. H. Smith, U.S.N.M.).

Virginia : Fredericksburg (Richardson, U.S.N.M.).

All other records are questionable.

\section{Mordellistena andreae var. ancilla Leconte}

(Pl. V, Figs. 7 and 8)

Mordellistena ancilla Leconte, 1862, p. 50, Georgia. J. B. Smith, 1882, pp. 87, 94. Blatchley, 1910, p. 1320.

Mordellistena varians Leconte, 1862, p. 50. J. B. Smith, 1882, pp. 87, 94. Blatchley, 1910, pp. 1320, 1321.

Description.-Posterior tibiae with two oblique ridges, anterior more oblique, extending entirely across outer face of tibiae, subapical ridge not included; first segment of posterior tarsi with three (sometimes with rudiment of a fourth) and second with two ridges.

Elongate; head usually yellowish or ferruginous in both sexes; thorax yellowish or ferruginous in male, sometimes with a shading at base; female usually with basal half of thorax black, sometimes entirely black; elytra yellowish or ferruginous with whole suture and lateral margin (broadest at middle) black; underside more or less black; otherwise like andreae.

Remarks.- This species is very variable. It is closely allied to $M$. andreae, from which it differs by the less distinct marginal and apical black area on the elytra. It is more common than andreae.

Previous Records.-Georgia and the central and southern states (Leconte) ; New York (Smith) ; Staten Island, New York (Davis); Cincinnati, 
Ohio (Dury) ; Jamaica, New York (Nicolay); Floral Park, New York (Schott); and Indiana (Blatchley).

Material examined.-Alabama: Langdale, Chambers County (H. H. Smith, U.S.N.M.).

District of Columbia: Washington, June 11 (U.S.N.M.).

Florida: Monticello, October 4-8 (A.M.N.H.).

Illinois : Rock Island, July 4 (Liljeblad); Savanna, July 29 (Forbes, J.U.) ; Urbana, May 30 (Hart, I.U.).

Maryland: Plummers Island, June 11-21, September 7 (Barber, Knab, U.S.N.M.).

Massachusetts : Framingham, June 16, July 4 (Frost).

North Carolina: Southern Pines, June 3 (Manee).

Ontario : Toronto (Crew coll., C.U.).

Pennsylvania: Easton, June 7 (J. W. Green).

Virginia : Fredericksburg, June 6-16 (Richardson, U.S.N.M.) ; Rosslyn. August 7 (H. H. Smith, U.S.N.M.).

\section{Mordellistena andreae var. ustulata Leconte (Pl. V, Fig. 9)}

Mordellistcna ustulata Leconte, 1862, p. 50, central and southern states. J. B. Smith, 1882, pp. 87, 94.

Description.-Posterior tibiae with two oblique ridges, subapical not in. cluded, anterior one more oblique, extending entirely across outer face of tibiae; first segment of posterior tarsi with three and second with two ridges.

Elongate; head, thorax, antennae, and palpi yellowish or somewhat ferruginous; elytra ferruginous with base (sometimes), suture, and margin narrowly black; underside nearly black with coxal plates yellowish; otherwise like andreae.

REmarks.-This species is also variable and closely allied to the two foreroing species. It is usually recognized by the very narrow black markings on the elytra, with almost no shading of the marginal spot visible.

Previous Records.-Central and southern states (Leconte); southwestcrn Pennsylvania (Hamilton); Cincinnati, Ohio (Dury); and Ames, Iowa (Wickham).

Material examined.-Alabama: no locality (Palm, A.M.N.H.).

Illinois : Fountain Cliff, July 20 (I.S.N.H.S.) ; Pesotum, June 5 (Hart, I.U.) ; Bowmanville and Beverly Hills, July 8-15 (Liljeblad).

Michigan : Milford, June 20 (Hubbell, U.M.).

New Jersey: Hemlock Falls, July 10, and Woodbury, Jume 7 (Hubbell, U.M.).

New York: Flatbush, Long Island, July 25 (A.M.N.H.).

Texas : San Diego, May 4 (E. A. Schwarz, U.S.N.M.). 


\section{Mordellistena semiusta Leconte}

(Pl. V, Fig. 10)

Mordellistena semiusta Leconte, 1862, p. 50, central and southern states. J. B. Smith, 1882, pp. 87, 94 . Blatchley, 1910, p. 1320.

Description.-Posterior tibiae with two parallel, oblique ridges, subapical not included, upper one crossing entire outer face of tibiae; first segment of posterior tarsi with three, second with two shorter ridges.

Nearly linear; head, thorax, clypeus, antennae, palpi, anterior legs, middle femora, and a humeral spot on elytra ferruginous ; rest of elytra, undersurface, middle tibiae and tarsi, posterior legs, and anal style nearly black, covered with somewhat reddish brown pubescence, short on head and thorax, long and rather coarse on the elytra.

Head moderately large; eyes large, rather coarsely granulated and hairy ; antennae long, filiform, reaching to base of thorax; third and fourth segments about equal in length, the two combined as long as fifth segment; sixth to tenth subequal in length, each about as long as fifth; last segment of maxillary palpi scalene triangular, rather broad and somewhat rounded on inner angle.

Pronotum about as broad as long, with surface minutely punctured; hind angles obtuse; basal lobe truncate at middle in front of scutellum; scutellum small, triangular, rather pointed.

Elytra nearly parallel to beyond middle; surface reticulate with raised punctures; anal style long and slender.

Length : to apices of elytra, $2.25 \mathrm{~mm}$; to tip of anal style, $3.25 \mathrm{~mm}$.

REMARKS.-This species is readily recognized, after the ridges have been examined, by the ferruginous head and thorax and the dark elytra with their humeral ferruginous spot. A slight variation in color has been observed. One specimen from Tennessee has a dark triangular area on the thorax in front of the scutellum and has the middle tibiae and tarsi pale; one from Wales, Maine, has the basal half of the thorax dark. The supposed type in the Leconte collection, now in the Museum of Comparative Zoology, is a male and agrees with the above description.

Previous REcords.-Central and southern states (Leconte); Cincinnati, Ohio (Dury); and Iowa City, Iowa (Wickham).

Material examined.-California: Atwood and San Diego, August 6 (C.U.) ; Los Angeles (Coquillet, U.S.N.M.).

Florida: Paradise Key, February 23 (Barber, U.S.N.M.).

Illinois : Fox Lake, July 3 (Ray).

Indiana: East Gary, June 29-30 (Liljeblad).

Maryland: Plummers Island, June 6 and July 8 (Currie, U.S.N.M.).

Maine: Wales, July (Frost).

Tennessee: Grassy Cove, Cumberland County, July 10 (Hubbell, U.M.). 
Texas : Brownsville, September (U.S.N.M.).

Virginia : Fredericksburg, June 15 (Richardson, U.S.N.M.).

\section{Mordellistena quadrinotata Liljeblad}

Mordellistena quadrinotata Liljeblad, 1921, p. 183, Miller, Indiana.

Description.-Posterior tibiae with two oblique, parallel ridges, subapical not included, interior one extending entirely across outer face of tibiae ; first segment of posterior tarsi with three and second with two ridges; all ridges strongly marked.

Form nearly linear; head testaceous, sometimes nearly black, sparsely covered with cinereous pubescence; antennae testaceous, becoming a little fuscous on four terminal segments; palpi a little darker than head; eyes black; prothorax black with long flavo-testaceous pubescence and a small ferruginous spot at apical angle on each side; elytra black, with an oblique, oblong-oval, testaceous spot, extending from humeral angle one-third of distance to tip of elytra but not reaching suture and one small, pale spot located in middle of each elytron, one-third of distance from its apex to base; surface of elytra covered with long, rather stiff, flavo-testaceous pubescence; undersurface black, except on last two segments of abdomen, which are testaceous, with pubescence like that of elytra ; anterior legs testaceous ; femora and tibiae of posterior legs black, tarsi fuscous; anal style testaceous.

Head a little narrower than prothorax, finely punctured; antennae filiform, covered with bristle-like hairs; first and second segments equal in length, rather robust, third and fourth segments each one-third shorter and a little narrower than second, fifth to tenth segments about equal in length, each one-third longer and wider than fourth, eleventh segment oval, longer than tenth; last segment of maxillary palpi nearly oval or obovate.

Pronotum finely and sparsely punctured, about as long as wide, widest a little in advance of base, which is truncate in front of scutellum, and with its sides slightly converging toward apex.

Elytra nearly parallel on anterior two-thirds, tapering thence to apex, rather coarsely scabrose over entire surface; anal style long and slender.

Length: to apices of elytra, $2.5 \mathrm{~mm}$.; to tip of anal style, $3 \mathrm{~mm}$.

REMARKs.-This species seems to be most nearly allied to $M$. semiusta Leconte, but differs in having the prothorax black with a small ferruginous spot on the apical angle, and by having two spots on each elytron. Only a single specimen, the type, was collected by me at Miller, Indiana. Two specimens from Milford, Michigan, differ from the type by having the head dark, and one, apparently a male, from Cornwall, Connecticut, differs from the type by having the head and thorax nearly black.

Previous Records.-Miller, Indiana (Liljeblad). 
Material examined.-Connecticut: Cornwall, August 15 (Frost). Michigan : Milford, June 20-27 (T. H. Hubbell).

\section{Mordellistena guttulata Helmuth}

(Pl. V, Fig. 11)

Mordellistena guttulata Helmuth, 1864, p. 105, Illinois. J. B. Smith, 1882, pp. 88, 94.

Description.-Posterior tibiae with two oblique ridges, subapical not included, upper almost crossing outer face of tibiae; first segment of posterior tarsi with three and second with two ridges, all strongly marked.

Elongate; black except antennae, palpi, and anterior and middle legs, which are somewhat brown or dusky; pubescence on thorax very long, gray, more reddish brown at base and sides; that on elytra gray, mottled, or in patches or broken bands; underside with gray pubescence.

Head minutely aciculate and punctured; eyes moderately large, not quite reaching occiput, rather coarsely granulated and with short hairs; antennae short, filiform, not quite reaching base of thorax; third segment a little shorter than fourth; fifth very little longer than fourth; sixth to tenth subequal in length, each a little shorter than fifth; last segment of maxillary palpi elongate, rounded on inner angle.

Pronotum one-fourth broader than long, broadest a little before base; sides rounded; basal angles subacute; basal lobe at middle in front of scutellum nearly truncate; surface finely aciculate and punctured; scutellum triangular, pointed at tip.

Elytra narrower than pronotum at base, gradually broadening to near apex, rather abruptly rounded to suture; surface finely punctured; anal style long and narrow, pointed.

Length: to apices of elytra, $2.75 \mathrm{~mm}$.; to tip of anal style, $3.75 \mathrm{~mm}$.

REMarks.-This species somewhat resembles $M$. pustulata Melsheimer, but differs from it in the ridges on the tibiae and in the shape of the antennae and maxillary palpi, in addition to which the pubescent blotches or spots on the elytra are less distinct. It is very rare, and only three specimens have been examined that fully agree with Helmuth's description. A slight variation occurs in one specimen, in which the head in front is rather ferruginous in color. The species was described from Illinois, but the type seems to have been destroyed, and I, therefore, have selected a neotype from East Saint Louis, Illinois, which I collected July 6, 1907.

Previous Records.-Illinois (Helmuth); southwestern Pennsylvania (Hamilton); and Plano, Texas (Tucker).

Material examined.-Michigan: Detroit (Hubbard and Schwarz, U.S.N.M.).

Pennsylvania: Delaware County; June 20 (Hubbard and Schwarz U.S.N.M.). 


\section{Mordellistena impatiens Leconte}

Mordellistena impatiens Leconte, 1862, p. 50, South Carolina. J. B. Smith, 1882, pp. 87, 94.

DESCRIPTION.-Posterior tibiae with two parallel, oblique ridges, subapical not included, upper one crossing entire outer face of tibiae; first segment of posterior tarsi with three small oblique ridges and second with two.

Subcuneate; black, with head, apical margin of thorax, four basal segments of antennae, palpi, anterior legs, middle femora, and last abdominal segment partly ferruginous, pubescence sericeous, reddish brown, rather long on elytra; anal style fusco-ferruginous.

Head moderately large; eyes small, rather coarsely granulated and with very short hairs; antennae short with third and fourth segments equal to fifth in length; last segment of maxillary palpi scalene triangular, somewhat rounded on inner angle.

Pronotum about one-fourth broader than long; surface with fine, raised punctures; hind angles nearly acute; basal lobe broadly rounded at middle in front of scutellum. Elytra somewhat convex, surface reticulate and with raised punctures; underside with rather long cinereous pubescence; anal style long, pointed.

Length : to apices of elytra, $2 \mathrm{~mm}$; to tip of anal style, $2.5 \mathrm{~mm}$.

REMARKS.- This species is rather dark with the apical margin of thorax ferruginous. Comparatively few specimens have been examined that agree with the supposed type, now in the Museum of Comparative Zoology.

Previous Records.-South Carolina (Leconte) and New York (Smith). Material eXamined.-Alabama: Langdale, Chambers County (H. H. Smith, U.S.N.M.).

Connecticut: Branford, August 4 (Zabriskie, A.M.N.H.).

District of Columbia: Washington, June 6 (Hubbard and Schwarz, U.S.N.M.).

Florida : Paradise Key, March 1 (Hubbard and Schwarz, U.S.N.M.).

North Carolina: Valley of Black Mountains, August 17 (Beutenmuller, A.M.N.H.).

\section{Mordellistena delicatula Dury}

Mordellistena delicatula Dury, 1906, p. 255, Cincinnati, Ohio. Blatehley, 1910, p. 1320.

Description.-Posterior tibiae with two oblique ridges, subapical not included, anterior one extending across outer face of tibiae; first segment of posterior tarsi with three and second with two ridges.

"Elongate, very slender, piceous in color, with front of head, mouthparts, front and middle legs and antennae pale rufo-testaceous. The elytra thickly covered with rather coarse, sage-green pubescence. Length $3.3 \mathrm{~mm}$. Seven specimens, Cincinnati, Ohio", (Dury). 
REMARKS.-This species is very slender and is readily recognized by its bright, shining, sage-green pubescence. A male specimen, collected at Cincinnati, Ohio, was kindly presented to me by Charles Dury. It agrees with the above description with the following additions: black; posterior legs fuscous; antennae filiform; third segment a little shorter than the fourth; fifth as long or nearly as long as the third and fourth segments combined; sixth to tenth about equal in length, each one-fifth shorter than the fifth; eleventh a little longer than the tenth, pointed; last segment of the maxillary palpi in male scalene triangular, with apical and inner sides nearly equal in length.

Previous Records.-Cincinnati, Ohio (Dury).

Material examined.-Indiana: Richmond (Phillips, U.S.N.M.).

Ohio: Cincinnati, June 14 (Dury).

Texas : Brownsville, September 6 (Schwarz, U.S.N.M.).

\section{Mordellistena nigricans (Melsheimer)}

(Pl. V, Fig. 12)

Mordellistena nigricans Melsheimer, 1846, p. 313, Pennsylvania.

Mordellistena nigricans, Leconte, 1862, p. 50. J. B. Smith, 1882, pp. 87, 94 . Blatchley, 1910, p. 1320.

Mordellistena nigerrima Helmuth, 1865, p. 96.

DEscription.-Posterior tibiae with two somewhat parallel, oblique ridges, subapical not included, upper one crossing entire outer face of tibiae; first segment of posterior tarsi with three shorter oblique ridges and second with two.

Nearly parallel; black, with four basal segments of antennae and labrum rufo-testaceous; palpi a little darker; female entirely black; both sexes covered with sparse cinereous pubescence.

Head large, nearly as broad as thorax, minutely punctured; eyes moderately large, finely granulated and hairy; antennae subfiliform, reaching base of thorax; third and fourth segments subequal in length, triangular; fifth as long as third and fourth combined and much broader at apex; sixth to tenth about equal in length, each with sides more parallel and diminishing in width; last segment of maxillary palpi triangular, with inner side much shorter than apical.

Pronotum very little broader than elytra at base, its surface with fine, raised punctures; basal angles subacute; basal lobe in front of scutellum rather broadly rounded; scutellum small, triangular, rounded at tip.

Elytra parallel to near apex; surface with rather coarse raised punctures, apex broad; anal style long and narrow.

Length : to apices of elytra, 2-2.25 mm.; to tip of anal style, $2.75-3 \mathrm{~mm}$.

REMARKs.- This species somewhat resembles $M$. vilis and aspersa, but 
entirely differs in the ridges. Several species have hitherto been placed under this name, since the dark color and ridges have been the main characters used for separation, but in view of recent observations it now becomes necessary to examine also the antennae and maxillary palpi. The supposed type in Melsheimer's collection, now in the Museum of Comparative Zoology, agrees with the above description, but is without the abdomen. Helmuth's $M$. nigerrima was, no doubt, a female of the present species, since he described it as being entirely black.

This insect does not appear to be very common in collections, perhaps on account of its small size and likeness to aspersa. It has been found as a parasite in the galls of Eurosta solidaginis by William Brodie ${ }^{2}$ but it has also been reported as boring in the pithy substance of the same gall formation (Eurosta), not feeding at all on the fly, by W. Hague Harrington, Ottawa, Canada $;^{3}$ it has been taken on Chenopodium, Helianthus, and Medicago. It appears from May to July.

Previous Records.-Pennsylvania (Melsheimer); central and southern states (Leconte); Illinois (nigerrima Helmuth); Argenteuil County, Quebec, and Ottawa County, Ontario (D'Urban); Toronto, Canada (Brodie); southwestern Pennsylvania (Hamilton); Cincinnati, Ohio (Dury); Fort Collins, Colorado (Gillette); Iowa City, Iowa (Wickham); Chariton, Iowa (Shimek); Owen, Monroe, and Perry counties, Indiana, May 16 to June 19 (Blatchley).

Material examined.-California: Los Angeles County (Koebele, U.S.N.M.) .

Georgia: Black Rock Mountains, May 20-25 (Bradley, C.U.).

Illinois : Edgebrook, June 1, Glen View, June 27, and Palos Park, June 25 (Liljeblad).

Kansas: Salina (Knaus).

Manitoba: Aweme, June 1 to August 10 (Criddle).

Maryland: Dorchester County, July 10 (Barber, U.S.N.M.).

Massachusetts : Sherborn, June 8, Framingham, July 4-27, and Chatham, July 14 (Frost).

Minnesota : Rochester (Nason coll., I.U.).

New Jersey : Phillipsburg, June 21 (J. W. Green).

New York: Ithaca, June 28 to July 19 (C.U.) ; Olcott, July 4 (Miss. E. W. Mank).

Ohio: Salineville (C.U.) ; Columbus, July 21 (Liljeblad).

Tennessee: Knoxville, May 15 to June 24 (Hill).

2 "Canadian Galls and Their Occupants-Eurosta solidaginis, Fitch," Can. Ent., 24 (1892) : 137.

${ }_{3}$ "Occupants of the Galls of Eurosta solidaginus Fitch," Can. Ent., 27 (1895) : 197. 


\title{
Mordellistena parva, new species
}

\author{
(Pl. V, Fig. 13)
}

Trpe.-From Pentwater, Michigan. A male, collected on July 20 by Emil Liljeblad; in the Museum of Zoology, University of Michigan (Liljeblad coll.).

PARATYPe.-A male, same data as type.

Description.-Posterior tibiae with two parallel, oblique ridges, subapical not included, upper one entirely crossing outer face of tibiae; first segment of posterior tarsi with three and second with two ridges; all ridges well marked.

Nearly parallel, very narrow ; covered with rather sparse cinereous pubescence; entirely black except four basal segments of antennae, which are fusco-ferruginous.

Head nearly as broad as thorax; antennae unusually long, two or three segments reaching beyond base of thorax; third segment one-fourth shorter than fourth, the two very narrow; fifth scarcely more than one-fifth longer than fourth; sixth to tenth subequal in length, each as long as fifth; last segment of maxillary palpi scalene triangular; eyes small, rather coarsely granulated, hairy.

Pronotum very slightly broader than long, a little broader than elytra at base; hind angles obtuse; surface reticulate and with fine raised punctures; scutellum very small, scarcely visible.

Elytra long and narrow, broadest near middle; surface reticulate, more strongly so near scutellum, and with rather coarse raised punctures; anal style long, slender and very pointed.

Length: to apices of elytra, $2 \mathrm{~mm}$; to tip of anal style, $2.75 \mathrm{~mm}$.

RemarKs.-This species somewhat resembles $M$. nigricans Melsheimer, but its antennae and palpi are very different and it is also much more slender.

\section{Mordellistena blatchleyi, new species}

TyPE.-From Dunedin, Florida. A male, collected on March 29, 1919, by W. S. Blatchley, to whom this species is dedicated; in the Museum of Zoology, University of Michigan (Liljeblad coll.).

Paratype.-A male, Enterprise, Florida, collected on April 18 by D. M. Castle; in the collection of the Museum of Zoology, University of Michigan (Liljeblad coll.).

DESCRIPTION.-Posterior tibiae with two parallel, oblique ridges, subapical not included, upper one entirely crossing outer face of tibiae; first seg'ment of posterior tarsi with three and second with two ridges.

Parallel; black, with antennae, palpi, anterior legs, middle tibiae and tarsi, and posterior tarsi fusco-ferruginous; antennae reaching to base of thorax, with third to fifth segments subequal in length; last segment of 
maxillary palpi scalene triangular, inner side longer than apical; elytra covered with reddish brown pubescence; in other respects similar to $M$. nigricans.

Length : to apices of elytra, $2 \mathrm{~mm}$; to tip of anal style, $2.75 \mathrm{~mm}$.

REMARKS.-This species resembles $M$. nigricans and minutalis, differing mainly in the antennal segments, palpi, and in the color of the legs.

\section{Mordellistena subfucus, new species}

(Pl. V, Fig. 14)

TrPe.-From Nogales, Santa Cruz County, Arizona. A male, collected on July 26, 1906, by F. W. Nunenmacher; in the Museum of Zoology, University of Michigan (Liljeblad coll.).

Allotype.-A female, same data as type.

Paratypes.-Five males and one female, same data as type; in the collection of F. W. Nunenmacher.

DESCRIPTION.-Posterior tibiae with two parallel, oblique ridges, subapical not included, upper one crossing almost the entire outer face of tibiae; first segment of posterior tarsi with three and second with two short, oblique ridges; all ridges strongly marked.

Linear; fusco-ferruginous, with antennae, apical segments of maxillary palpi in female, and abdomen nearly black, covered with sericeous yellowish pubescence more dense and olive on elytra, a little lighter in male.

Head large, nearly as broad as thorax, finely punctured; eyes large, coarsely granulated, hairy; antennae long, reaching beyond base of thorax, subfiliform; third and fourth segments narrow, equal in length; fifth segment one-fourth longer than fourth but much broader at tip; sixth to tenth each equal in length to fifth; eleventh a little longer than tenth, oval; last segment of maxillary palpi elongate, scalene triangular, with inner side longer than apical.

Pronotum a little broader than elytra at base, one-fourth broader than long, broadest a little before base, with apex very little narrower than base; surface finely punctured; basal lobe at middle in front of scutellum broad, truncate or very slightly emarginate; scutellum small, rather broadly rounded at tip.

Elytra a little narrower than thorax at base; sides nearly parallel to below middle; apex more pointed than usual, with well-defined margin; surface reticulate, with raised punctures; anal style longer in male than in female, slender, pointed.

Length : to apices of elytra, $2.5 \mathrm{~mm}$. (male), $3.25 \mathrm{~mm}$. (female); to tip of anal style, $3.5 \mathrm{~mm}$. (male), $4 \mathrm{~mm}$. (female).

REMarks.-This species to some extent resembles $M$. nubila Leconte and was considered to be identical with it until the type was examined. The 
original description of nubila Leconte (1858:75) states: "Elytris sutura anguste, lateralis, busque prope medium paulo infuscatis" ("elytral suture narrowly, sides also at middle a little dark"). Leconte, however, in his later description in the Synopsis of the Mordellidae of the United States (1862: 50) did not say anything about the darkness of the suture and side margin of nubila, and thus the two descriptions by Leconte do not agree. J. B. Smith, in his synopsis (1882: 88) did not make the matter any clearer. The type has been examined by me, and was found to have the basal half of the elytral margin and the elytral suture narrowly dark.

\section{Mordellistena ferruginoides Smith}

Mordellistena ferruginoides Smith, 1882, pp. 87, 94, Georgia.

Description.-Posterior tibiae with two oblique ridges on outer face, subapical not included, ridges parallel, anterior one extending almost across outer face of tibiae; first segment of posterior tarsi with three and second with two oblique ridges.

Elytra without distinct markings. Fusco-ferruginous; elytra black, pubescence fine and dark. $2 \mathrm{~mm}$., Georgia.

Distinct from any of the others of this group by the contrasted elytra and body. One specimen only, coll. by Dr. Horn. (Smith)

REMARKs.- This species is unknown to me; the type has not been found. Specimens have been seen that agree more or less with the above description by Smith, but as the antennae and palpi are not alike in all the specimens, it is impossible to say which of them may belong to ferruginoides.

\section{Mordellistena testacea Blatchley}

Mordellistena testacea Blatchley, 1910, p. 1321, Putnam County, Indiana.

Description.-Posterior tibiae with two parallel ridges, subapical not included, upper one much longer and extending almost across outer face of tibiae; first segment of posterior tarsi with three and second with two ridges.

Elytra and entire body pale brownish yellow.

Slender, parallel. Uniform dull brownish yellow; pubescence rather close, paler yellow. Length: $2.3 \mathrm{~mm}$.

Putnam County: rare. July 25. Taken from flowers of Solidago. (Blatchley)

REMARKs.-I have not examined the type.

\section{Mordellistena wickhami, new species}

$$
\text { (Pl. V, Fig. 15) }
$$

TyPe.-From Leeds, Utah. A male, collected August 4 by H. F. Wickham; in the Museum of Zoology, University of Michigan (Liljeblad coll.).

Allotype.-A female, St. George, Utah, collected in July by H. F. Wickham; in the Museum of Zoology, University of Michigan (Liljeblad coll.). 
Paratype.-Same data as type; in the collection of H. F. Wickham, from whom the specimens were received and in whose honor this species has been named.

Description.-Posterior tibiae with two ridges, subapical not included, upper one almost crossing outer face of tibiae, and a small rudimentary third ridge; first segment of posterior tarsi with three ridges and rudiment of a fourth ridge; second segment with two ridges.

Elongate, narrow; entirely fulvous except abdominal segments, which are dark, with bluish reflections; eyes black; upper surface entirely covered with very fine, sericeous, yellowish pubescence which, on upper surface in certain lights, has a greenish tint.

Head large, finely aciculate and punctured; antennae filiform, a little longer than head and thorax; third and fourth segments short, the two combined about as long as fifth segment; sixth to tenth subequal in length, each one-fourth shorter than fifth in male but somewhat longer than fifth in female; last segment of maxillary palpi scalene triangular; eyes moderately large, coarsely granulated and hairy.

Pronotum very little broader than long, finely aciculate and punctured; hind angles obtuse; basal lobe broadly rounded at middle in front of scutellum.

Elytra elongate, feebly rounded at sides; surface finely reticulate and punctured; anal style long, pointed.

Length : to apices of elytra, $3.75-4 \mathrm{~mm}$.; to tip of anal style, 5-5.5 $\mathrm{mm}$.

REMARKS.-This species does not resemble any of those which have the second ridge of the posterior tibiae crossing the outer face; it is linear, narrow, and in shape somewhat like M. splendens Smith, though in color it is different, being nearly uniform pale yellowish or somewhat reddish yellowbrown, very silky in appearance, and with the abdominal segments dark.

\section{Mordellistena crinita, new species}

Trpe.-From Columbus, Texas. Collected June 3-6 by Hubbard and Schwarz; in the collection of the United States National Museum; sex undetermined.

Paratypes.-Three, same data as type, in the Museum of Zoology, University of Michigan (Liljeblad coll.).

Description.-Posterior tibiae with two oblique ridges, subapical not included, upper one crossing outer face of tibiae; first segment of posterior tarsi with three, second with two ridges.

Elongate; entirely pale yellow or fulvous, except eyes which are black; surface sparingly covered with long, coarse, yellow hairs.

Head comparatively large, very minutely aciculate, punctured; eyes coarsely granulate, hairy; antennae not reaching base of thorax; third and 
fourth segments very small, the two about as long as fifth, which is twice as broad at apex; sixth to tenth each nearly as long as fifth; last segment of maxillary palpi scalene triangular, with apical side a little longer than inner, inner angle somewhat rounded.

Pronotum one-fourth broader than long, a little broader than elytra at base; surface minutely aciculate, sparsely and finely punctured; hind angles obtuse; basal lobe emarginated at middle in front of scutellum, scutellum sharply triangular.

Elytra a little broader toward apical third; surface minutely aciculate, sparsely and finely punctured; anal style comparatively long and pointed.

Length : to apices of elytra, $2.5 \mathrm{~mm}$.; to tip of anal style, $3.5 \mathrm{~mm}$.

REMARKS.-This species may be closely allied to M. testacea Blatchley, the type of which I have not examined, but according to the description testacea should have very close pubescence, whereas the present species is very sparsely covered with long setae.

\section{Mordellistena ruficeps Leconte}

(Pl. V, Fig. 16)

Mordellistena ruficeps Leconte, 1862, p. 50, central and southern states. J. B. Smith, 1882, pp. 88, $95 . \quad$ Blatchley, 1910, p. 1320.

Description.-Posterior tibiae with two parallel, oblique ridges, subapical not included, upper much longer, crossing outer face of tibiae; first segment of posterior tarsi with three, second with two ridges.

Linear, a little broader in female; black, with head ferruginous; antennae, palpi, anterior legs, middle tibiae and tarsi, and apical margin of abdominal segments testaceous; female with hind tibiae and tarsi also testaceous; sparsely covered with brownish gray pubescence.

Head rather large, minutely punctured; eyes rather coarsely granulated, hairy; antennae short, third segment a little shorter than fourth, fifth to tenth subequal in length, each one-fourth longer than fourth; eleventh little longer than tenth, oval; last segment of maxillary palpi with the form of an isosceles triangle, inner and apical sides equal.

Pronotum one-third broader than long, a little broader than elytra at base; surface reticulate and with fine raised punctures; basal lobe nearly truncate at middle in front of scutellum or very slightly emarginate; scutellum triangular.

Elytra reticulate and with rather strongly raised punctures; apex broadly rounded; anal style long and slender, pointed.

Length : to apices of elytra, $2.25 \mathrm{~mm}$; t to tip of anal style, $3.25 \mathrm{~mm}$.

ReMarks.- This species is readily recognized, after the ridges have been examined, by its blackness and ferruginous head. The supposed type, ap- 
parently a female, in the Leconte collection, at the Museum of Comparative Zoology, has been examined by me and found to agree with the above description.

Previous RECORDs.-Central and southern states (Leconte); and New York (Smith).

Material examined.-California : Santa Barbara, August 3 (Miss E. W. Mank).

Florida: Crescent City, April 23 (A.M.N.H.) ; Paradise Key, February 23 (Schwarz and Barber, U.S.N.M.).

Indiana: Millers, July 4 (Liljeblad).

Maryland: Plummers Island, June 20 (Barber, U.S.N.M.).

Massachusetts : Sudbury, August 8 (Darlington).

New Jersey: Westville, July 21 (J. W. Green); Lakewood, May 26 (Hubbard and Schwarz, U.S.N.M.).

Ohio : Salineville (C.U.).

Pennsylvania: Point Pleasant, July 26 (J. W. Green).

West Virginia : Berkeley (Hubbard and Schwarz, U.S.N.M.).

\section{Mordellistena nubila (Leconte)}

Mordella nubila Leconte, 1858, p. 76, San Diego, California.

Mordellistena nubila (Leconte), 1862, p. 50. J. B. Smith, 1882, pp. 88, 95.

Description.-Posterior tibiae with two oblique, parallel ridges on the outer face, and a rudiment of a third ridge subapical not included, anterior ridge extending almost across outer face of tibiae; first segment of posterior tarsi with three, second with two ridges.

Elongate linearis, flavo ferruginea, dense luteo-pubescens subsericea, thorace latitudine haud breviore, ab basin utrinque mordice sinuato, disco postice paulo obscuriore, elytris sutura anguste, lateris-busque prope medium paulo infuscatis; stylo anali longo; parapleuris tarsisque posticis infuscatis. Long. 15 .

One specimen, San Diego, California (Leconte, 1858).

Hind tibiae with two oblique ridges on the outer face. Ridges parallel, the anterior one extending almost across the outer face of the tibiae. First joint of hind tarsi with three, second with two oblique ridges.

Elytra without distinct markings; pubescence brownish-gray; ferruginous; sides of pectus and elytra darker; hind tibia with a rudiment of a third, first joint of tarsi with a rudiment of a fourth ridge, 13. San Diego, California. (Leconte, 1862)

REMARKs.-Unfortunately, I have been unable to secure series of specimens of this species for examination, but have examined the supposed type, a female, in the Museum of Comparative Zoology. This specimen shows, very distinctly, the elytra with the suture and lateral margin from base to middle dark, otherwise flavo-ferruginous. A rudiment of a third ridge is seen on the tibiae, but the rudimentary fourth ridge on the first segment of the tarsi is but very faintly indicated. 


\section{Mordellistena splendens Smith}

(Pl. VI, Fig. 12)

Mordellistena splendens Smith, 1882, pp. 88, 95, Illinois and Florida; 1883, p. 81. Blatchley, 1910, p. 1320.

Description.-Posterior tibiae with two ridges, sometimes with rudiment of third, subapical not included, upper ridge more oblique and nearly crossing outer face of tibiae; first segment of posterior tarsi with three or sometimes four ridges, second with two.

Subcuneate, slender; head piceo-testaceous, sometimes nearly black, front more or less rufo-testaceous; basal segments of antennae and palpi rufo-testaceous; prothorax fusco-testaceous, sometimes more rufous, occasionally very dark; elytra like thorax in color; underside varying from fusco-testaceous to nearly black; all the legs usually testaceous; head with short, rather sparse, sericeo-cinereous pubescence; thorax and especially elytra densely covered with long sericeous, argenteous pubescence.

Head moderately large, with fine punctures; eyes large, finely granulated, hairy, denser in female; antennae short, reaching to about middle of thorax; all segments subequal in length; third and fourth segments narrow; fifth to tenth broader, somewhat serrate; third segment in male one-fourth longer than fourth; last segment of maxillary palpi scalene-triangular, inner side longer than apical, more sharply angled in male.

Pronotum one-third broader than long, broadest at base; surface reticulate and with fine raised punctures; basal lobe broad at middle in front of scutellum, and truncate (visible only in denuded specimens); basal angles subacute.

Elytra long, nearly four times as long as thorax, surface reticulate and with rather coarse raised punctures ; apex somewhat pointed ; anal style very long and slender.

Length : to apices of elytra, 4-5 mm.; to tip of anal style, $5.25-6.5 \mathrm{~mm}$.

REMARKS.-This species is readily recognized, after the ridges have been examined, by its beautiful silvery pubescence, noticeable in perfectly clean specimens, although older specimens often become greasy and have a blackish appearance. Rudimentary ridges may be found in some individuals, both on the tibiae and the tarsi. According to J. B. Smith, this species should have four ridges on the first segment of the posterior tarsi, but the supposed type (from Illinois), in the Museum of Comparative Zoology, has only three ridges with a rather strong rudiment of a fourth ridge on the right leg only, not visible on the left. I have retained this species in the group bearing four ridges on the first segment of the posterior tarsi since the other type (from Florida) has not been examined; moreover, there is some error in regard to the ridges of this and the following species, floridensis (see note under that species). 
Previous records.-Illinois, Florida, and Pennsylvania (Smith); Lake Worth, Florida (Hamilton); Cincinnati, Ohio (Dury); Ames, Iowa (Osborn); and Staten Island, New York (Davis).

Material eXamined.-Florida: St. Nicholas (Ashmead, U.S.N.M.).

Maryland: Plummers Island, July 7 (McAtee, U.S.N.M.).

New Jersey: Anglesea, August 13 (J. W. Green); Cape May (Mason).

New York: Barren Island, Long Island, August 7 (U.S.N.M.).

\section{Mordellistena floridensis Smith}

(Pl. V, Fig. 17)

Mordellistena floridensis Smith, 1882, pp. 88, 95, Florida. D. Sharp, 1901, p. 268.

Description.-Posterior tibiae with two parallel, oblique ridges, in some specimens with a rudimentary third ridge, subapical not included, anterior ridge crossing outer face of tibiae; first segment of posterior tarsi with four ridges, sometimes with only three and rudiment of a fourth ridge, second segment with two ridges and in some specimens, the rudiment of a third ridge.

Linear ; entirely black except mentum, antennae, palpi, and anterior legs, which are more or less fusco-ferruginous; surface covered with sericeous, reddish brown pubescence.

Head rather large, somewhat strongly punctured; eyes large, rather coarsely granulated, hairy; antennae filiform, about as long as head and thorax; third segment one-fourth shorter than fourth; third and fourth combined one-fourth longer than fifth; fifth to tenth each subequal in length; last segment of maxillary palpi triangular, with inner side much shorter than apical.

Pronotum about as broad as long; surface reticulate with fine punctures; basal lobe broad and nearly truncate at middle in front of scutellum; hind angles subacute; scutellum small, triangular, rather pointed.

Elytra long, tapering very little from middle to apex, which is rounded; surface reticulate with raised punctures; anal style very long and slender, pointed.

Length : to apices of elytra, 3.5-3.75 $\mathrm{mm}$.; to tip of anal style, 5.5-6 mm.

REMARKS.-This species resembles $M$. splendens except in color and the shape of the antennae and palpi. The eyes are unusually large. The specimens at hand agree well with Smith's description (1882: 88), but not with his notes (page 95), nor with the illustration (Pl. 3, Fig. 6). In the synopsis (page 88) Smith stated that this species should have the "first joint of hind tarsi with four, second with two oblique ridges," exactly the same as given for $M$. splendens, but in his note (page 95) he said, "closely related to the preceding (splendens) but distinct from it by the number of ridges on second tarsal joint." According to Plate 3, Figure 6 (tibiae of species 44-49, floridensis being 44) the species does not even belong to the group in 
which he placed it, since the drawing shows the tibiae with three ridges, the first segment of the tarsi with three and the second segment with two, and none of the ridges on the tibiae crosses the outer face. On account of these conflicting notes it is impossible to identify $M$. floridensis.

The type of this species has not been located by me, but there can be hardly any doubt that it fits the above description. One specimen from C'edar Keys, Florida, is under this name in the Leconte collection in the Museum of Comparative Zoology and may be the type; it agrees with the above description. The larva has been bred in stems of Uniola paniculata and a very interesting note on it is given by C. V. Riley. ${ }^{4}$

Previous Records.-Florida (Smith); Lake Worth, Florida (Hamilton). Material examined.-Alabama : Delchamps, June 11 to July 1 (Löding); Kushta, August 23 (A.M.N.H.).

California: Humboldt County, June 18 (H. S. Barber, U.S.N.M.).

Florida: Paradise Key, June 8 (D. M. DeLong); Enterprise (Ashmead, U.S.N.M.) ; no locality (Ashby, U.S.N.M.) ; Fort Myers, April 1 (A.M.N.H.)

Texas: Chisos Mountains, July 8, and Seabrook, August 6 (Green).

\section{Mordellistena rufa Liljeblad}

Mordellistena rufa Liljeblad, 1917, p. 11, Palos Park, Illinois.

Description.-Posterior tibiae with two oblique, somewhat parallel ridges, subapical not included, anterior one extending almost across outer face of tibiae; first segment of posterior tarsi with four ridges, second with two.

Ferruginous; elytra with lateral margin from base to middle, and suture black; mesosternum black; hind coxal plate and abdomen clouded with black.

Head finely punctured in circular rows; antennae subfiliform, about as long as thorax, densely covered with fine hairs; third and fourth segments about equal in length, the two combined as long as fifth; sixth to tenth each subequal in length, very little shorter than fifth; last segment of maxillary palpi scalene triangular, with inner side a little shorter than apical.

Pronotum a little broader than long, broadest near base; basal lobe slightly emarginate in front of scutellum; hind angles obtuse; surface with very fine and sparse punctures.

Elytra broadest at middle, gradually tapering to apex, which is narrowly pointed; surface with comparatively coarse punctures and rather long pubescence.

Length: to apices of elytra, $3 \mathrm{~mm}$; to tip of anal style, $4 \mathrm{~mm}$.

REMARKs.-This species resembles M. ustulata, but differs in the ridges, which are strongly indicated and somewhat in the basal lobe of the pro-

4 "Coleopterous Larvae with So-called Dorsal Prolegs," Proc. Ent. Soc. Wash., 2 (1892) : 319-25. 
notum. When more specimens can be made available for study this species may be considered as a variation of ustulata, which, no doubt, is extremely variable. The single known specimen (type) is preserved in the collection of the Museum of Zoology, University of Michigan (Liljeblad coll.).

\section{Mordellistena smithi Dury}

Mordellistena smithi Dury, 1906, p. 177, Cincinnati, Ohio. Blatehley, 1910, p. 1322.

\section{DESCRIPTION.-}

Piceous black. Anterior and middle legs testaceous. Elytra rufo-piceous with lighter red splotches on humeri extending obliquely backward toward the suture. The amount of red varies, in some specimens being more extended. Pubescence coarse, yellow.

Hind tibia with three, 1st tarsal joint with three, $2 \mathrm{~d}$, with one, well defined ridges. Length $3.5 \mathrm{~mm}$. 14 specimens, Cincinnati, Ohio. (Dury)

REMARKs.-This species is readily recognized by the color, after the ridges have been examined. Several specimens have been examined by me. Two of these were kindly presented to me by Dury, and from these the following notes were taken.

Posterior tibiae with three nearly equal, parallel ridges on outer face, subapical not included; first segment of posterior tarsi with three, second with two ridges.

Male with head and thorax black; antennae and palpi rufo-testaceous; elytra nearly black with an oblique humeral vitta, reaching to a little below middle of elytra, covered with cinereous pubescence; underside black with cinereous pubescence; anterior legs testaceous; posterior leg's fuscous; anal style black. Female like male with exception of elytra, which are shining rufo-piceous with a darker cloud, in certain lights, at base.

Antennae with first to fourth segments narrow; fifth to tenth slightly serrate, nearly twice as wide; third and fourth about equal in length, each one-fourth shorter than fifth; sixth to tenth about equal in length; eleventh one-third longer than tenth; antennae in male more filiform and less serrate than in female.

Previous Records.-Cincinnati, Ohio (Dury), and Putnam and Crawford counties, Indiana (Blatchley).

Material examined.-Arkansas : Fayetteville, August 10 (Knaus coll.).

Indiana: Marion County, July 16, August 3 (Blatchley).

Maryland: Plummers Island, July 21 (McAtee, U.S.N.M.).

Virginia : Rosslyn, August 7 (H. H. Smith, U.S.N.M.).

\section{Mordellistena morula Leconte}

Mordellistena morula Leconte, 1862, p. 50, Lake Superior and Minnesota. J. B. Smith, 1882, pp. 88, 96; 1883, p. 4. Blatchley, 1910, p. 1322.

DESCRIPTION.-Posterior tibiae with three short, oblique, parallel ridges, 
subapical not included; first segment of posterior tarsi with three, second with two ridges.

"Elytra not banded. Nearly linear, entirely black, pubescence brownish gray. .11-15. Lake Superior and Minnesota."

REMARKs.- - I have been unable to verify this species fully. It was originally described as entirely black with brownish gray pubescence, and the supposed type or first specimen in the Leconte collection, now in the Museum of Comparative Zoology, agrees with this account. The type, however, is not clean, and it is therefore impossible to say if it possesses any other characters that may separate it from the aspersa group, which it no doubt resembles. Smith followed Leconte, but added a note to the effect that since the species seemed to vary, he queried whether aspersa and morula did not intergrade. In a note on specimens "Nos. 12 D.C. and 18 Col." he said that the pubescence was paler than in any examples he had seen before. Blatchley said that the species resembles pustulata, but that the pubescence is yellowish, distributed unevenly over the surface. Several specimens have been seen by me that may be of this species, but for the present it is impossible to be certain.

Previous Records.-Lake Superior and Minnesota (Leconte) ; New York (Smith); District of Columbia and Colorado (Ulke); Cincinnati, Ohio (Dury) ; Staten Island, New York (Leng); West Point, New York (Davis); Dolores, Bellevue, Montrose, Garland, Veta Pass, West Cliff, and Fort Collins, Colorado (Wickham); and Lake County, Indiana (Blatchley).

\section{Mordellistena nunenmacheri Liljeblad}

(Pl. V, Fig. 21)

Mordellistena nunenmacheri Liljeblad, 1918, p. 157, Oregon and California.

Description.-Posterior tibiae with three short, slightly oblique, parallel ridges, subapical not included; first segment of posterior tarsi with three, second with two ridges. Some specimens have a small, rudimentary fourth ridge on the tibiae and first segment of tarsi ; all ridges small and difficult to distinguish.

Linear; entirely black, covered with fine reddish brown and gray pubescence. Head large, nearly as broad as thorax, finely punctured; eyes small, coarsely granulated, not hairy; antennae reaching to base of thorax; fifth to eleventh segments broad, nearly forming an elongated club; fourth segment shortest, a little shorter than third; last segment of maxillary palpi in male broadly scalene triangular; in the female narrower, more elongate.

Pronotum about one-fourth broader than long ("thorax longer than wide" is an error in the original description), finely punctured; basal angle subacute; basal lobe at middle in front of scutellum with a diagnostic V-shaped notch, sometimes less strongly indicated. Scutellum triangular, more pointed in male than in female. 
Elytra nearly parallel to near apices, which are obliquely truncate; anal style long, rather blunt at tip.

Length : to apices of elytra, $3.75 \mathrm{~mm}$; to tip of anal style, $5.75-6 \mathrm{~mm}$.

REMARKs.-This species is somewhat like $M$. unicolor, but the rather deeply notched middle thoracic lobe distinguishes it from other species. The type is in the Museum of Zoology, University of Michigan (Liljeblad coll.).

Previous RECords.-Josephine County, Oregon, and Plumas County, California (Liljeblad).

Material examined.-California: La Fevre Creek, Tulare County, May 2 (Hopping).

\section{Mordellistena pustulata (Melsheimer)}

$$
\text { (Pl. V, Fig. 22) }
$$

Mordella pustulata Melsheimer, 1845, p. 314, Pennsylvania.

Mordellistena pustulata, Leconte, 1862, p. 50. J. B. Smith, 1882, pp. 88, 95. Blatchley, 1910, p. 1322.

DESCRIPTION.-Posterior tibiae with three short, oblique, parallel ridges, subapical not included; first segment of posterior tarsi with three, second with two ridges. In very small individuals there may be only two ridges and a rudimentary third ridge.

Subcuneiform; entirely black, except the three or four basal segments of antennae, palpi, and anterior legs, which are fusco-ferruginous; pubescence on head and thorax fine, rather long, sericeous ; elytra sprinkled with numerous cinereous spots, which sometimes form narrow broken bands; underside with somewhat cinereous pubescence; anal style with cinereous pubescence at base.

Head minutely aciculate and punctured; eyes small, rather coarsely granulated and hairy; antennae long, filiform in male, shorter, more subserrate in female; third segment one-third shorter than fourth; fifth to tenth segments subequal in length, each one-fourth longer than fourth; third and fourth segments about equal in length in female; fifth to tenth each very little longer than third and fourth combined; last segment of maxillary palpi elongate in both sexes, somewhat cultriform.

Pronotum very little broader than long, finely punctured; basal lobe in front of scutellum not very prominent, rounded. Elytra more coarsely punctured; anal style long and slender.

Length : to apices of elytra, 2-4 mm.; to tip of anal style, $2.5-5.5 \mathrm{~mm}$.

REMARKS.-This species is one of the few in the genus that can be recognized at sight after the tibial ridges have been examined. The silvery gray pubescent spots on the elytra will, usually alone, suffice to identify it. The nearest allied species is $M$. guttulata, which seems to be very rare and which differs by having the upper ridge on the tibiae crossing the outer face. $M$. 
pustulata is rather variable in size and somewhat so in the darkness of the antennae and legs, but I have been unable to find any character sufficiently positive to split this well-marked species. The slight difference in the antennae is sexual, those of the male being filiform and those of the female subserrate and a little shorter. The smallest individuals seen are from Illinois and Florida and the largest from Canada. The insect appears from February to September. The larva has been reared in stems of Ambrosia trifida by F. M. Webster ${ }^{5}$ and in Xanthium strumarium by D. W. Coquillett.

Previous ReCORDS.-Pennsylvania (Melsheimer); central, southern, and western states (Leconte); United States (Smith); southwestern Pennsylvania (Hamilton) ; Cincinnati, Ohio (Dury) ; Denver, Fort Collins, La Veta, and Garland, Colorado (Wickham) ; Newark, Delaware (Houghton) ; Plano, Texas (Tucker); Indiana, throughout the state (Blatchley); and New York state (Nicolay).

Material examined.-Alabama: Langdale, Chambers County (H. H. Smith, U.S.N.M.).

Arizona: Bill Williams Fork, August (Snow, K.U.) ; Prescott (Palm, A.M.N.H.).

California: Westmoreland, August 14 (Bradley); Leona Mountains, August 27 (C.U.); Del Monte, April (Fenyes); Tupico, September 10 (Bradley); Los Angeles (Coquillett, U.S.N.M.).

Connecticut: New Haven, June 6 (Champlain).

District of Columbia: Washington (U.S.N.M.).

Florida: Enterprise, April 15 (Castle); Daytona, June 7 (Frost coll.); La Belle, April (A.M.N.H.); Alachua County, May 4 (Alexander and Walker) ; Paradise Key, February 22 (Hubbard and Schwarz, U.S.N.M.); Tampa (U.S.N.M.).

Georgia : Billys Island, Okefenokee Swamp, June; Tysbee Island, April 20 ; Black Rock Mountains, May 20-25; Chester, June (C.U.) ; Thunderbolt, Savanna, April 20.

Illinois : Palos Park and Willow Springs, Cook County, June 18 to July 10 (Gerhard, Wolcott, Psota, Selinger, and Liljeblad) ; Fox Lake, July 25 (Gerhard) ; Algonquin, Normal, Mount Carmel, Urbana, Quincy, Springfield, Anna, Grand Tower, Mattoon, Metropolis, Pulaski, and Fountain Bluff, May 13 to August 8 (I.U.) ; Clark, June 12, and Kankakee, August 25 (Wolcott).

Indiana: Millers and Mineral Springs, May 31 to July 4 ( Gerhard, Wolcott, and Liljeblad).

Iowa: Iowa City, June 4 (Stoner) ; Russell, May 29 (Titus, U.S.N.M.). Kansas : Salina, (Knaus) ; Harper, Cowley, Hodgeman, and Miami counties (Beamer, K.U.) ; Onaga (Baker, U.S.N.M.).

5 "Some Original Descriptions by Guenée," Can. Ent., 33 (1901) : 176. 
Kentucky : Fordsville (Ainslie).

Louisiana: Alexandria, April 2 (Bottimer); Opelousas (Pilate, U.S.N.M.) .

Maine: Monmouth, June 20, and Wales, July 10 (Frost).

Manitoba: Aweme, June 19 (Criddle).

Maryland : Plummers Island (U.S.N.M.).

Massachusetts : Framington, June 8 to August 4 (Frost) ; Lawrence, June (Miss E. W. Mank) ; Nantucket Island (I.U.).

Michigan: Milford, June 26 (Hubbell, U.M.).

Missouri, Atherton, May 25 (Adams, K.U.).

New Hampshire: Hampton, June 2 (Shaw); Belknap County (I.U.).

New Jersey : Phillipsburg, May 1 to July 12 (J. W. Green) ; Atco ; Woodbury and Westville, July 21; Riverton, May 30 (Castle).

New York: Ithaca, July (Atkinson, C.U.), and June 28 (Dietrich) ; Flatbush, June 11 (A.M.N.H.).

North Carolina: Southern Pines, May 13 (Manee).

Ohio: Columbus, July 16 to July 20 (Liljeblad) ; Salineville (C.U.).

Ontario : Toronto, May 16 (Crew coll., C.U.).

Pennsylvania: Philadelphia, April 21; Delaware County, June 20; Harrisburg, July 1 (Knull) ; Bloomfield, July 17 (Trimble) ; Enola, June 12 (Knull) ; Reading, August 5 (Gerhard).

South Dakota: Elmore, July 15 (Webb, U.S.N.M.).

Tennessee: Knoxville, May 30 (Hill).

Texas: Seebrook and Harrisburg, July 31, August 2 (J. W. Green); Sharpsburg, May 10 (Schwarz, U.S.N.M.) ; Brownsville, June 22 (I.U.).

Vermont: Dummerston, July 14 (Frost).

Virginia: Boykins, June 10; Fredericksburg, June 6 (Richardson, U.S.N.M.).

West Virginia: White Sulphur Springs, July (Fenyes).

\section{Mordellistena convicta Leconte}

(Pl. V, Fig. 23)

Mordellistena convicta Leconte, 1862, p. 50, Kentucky. J. B. Smith, 1882, pp. 88, 95. Blatchley, 1910, p. 1322.

DESCRIPTION.-Posterior tibiae with three short, oblique, parallel ridges, subapical not included; first segment of posterior tarsi with three ridges, second with two. Upper tibial ridge often very short, and first segment of posterior tarsi, in some specimens, with a rudimentary fourth ridge, especially in male.

"Black, linear, elytra with lines of brownish gray pubescence, confluent behind, 12. Kentucky" (Leconte).

Subcuneiform; entirely black, covered with fine brownish gray pubes- 
cence which, on elytra, is formed in four or five narrow, longitudinal lines; antennal segments, last segment of maxillary palpi, and punctation as in $M$. pustulata; the anal style, however, is rather unusual in being only onefourth longer than the last abdominal segment, and more abruptly pointed; it is variable in size, and the male is narrower than the female. It may easily be mistaken for $M$. aspersa, but differs from that species in the ridges, pubescence, and anal style.

Length : to apices of elytra, 2.5-3 mm.; to tip of anal style, $3-3.75 \mathrm{~mm}$.

REMARKs.-When I had the opportunity of examining the supposed type of $M$. convicta, the first specimen in Leconte's collection under that name, it became evident that it was identical with Mordellistena syntaenia Liljeblad. $M$. convicta was described from Kentucky. The first specimen in the Leconte collection has no exact locality label, only a yellow tag which is supposed to indicate the "central valley" (Illinois, Michigan, etc.). Smith, in his synopsis, said that he had seen Leconte's type and from it had drawn his figure, but this figure plainly shows five gray pubescent lines on each elytron (while syntaenia has only two) with the one nearest the suture only partly divided near the base. Furthermore, neither Leconte nor Smith mentioned anything about the ferruginous color of the antennae, mouth parts, and anterior legs, as shown by the supposed type or first specimen, although this character, when present, was always observed and mentioned by Leconte in his descriptions of species of Mordellistena, at least when the general color was not uniform.

From the above evidence, I am of the opinion that the specimen now the first in the Leconte collection under the name of convicta is not the original specimen that was before that author when he described the species.

Previous REcords.-Kentucky (Leconte); Cincinnati, Ohio (Dury); Marion and Perry counties, Indiana (Blatchley).

Material examined.-Alabama: Langdale, Chambers County (H. H. Smith, U.S.N.M.).

Illinois : Normal, June 27 ; Quincy, June 11; Anna, June 28; Algonquin, July 12; Urbana and Bishop, June 28 (I.U.) ; Palos Park, Cook County, June to July (Liljeblad) ; Fox Lake, July 25 (Gerhard).

Indiana: Hessville, Osburn, and Miller, May 30 to July 4 (Gerhard, Wolcott, and Liljeblad).

Kansas: Lawrence (K.U.).

Maine: Wales and Paris, June 23 to July 9 (Frost).

Manitoba: Aweme, June 19 (Criddle).

Maryland: Plummers Island, May 24 (McAtee, U.S.N.M.).

Massachusetts: Natick and Framingham, June 5 to August 4 (Frost); Monterey, July 15 (Frost).

Michigan: Sand Point, Huron County, June 23 (Hubbell); Pigeon, Huron County, July 1 (Hussey). 
New Hampshire: Hampton, May 22 (Shaw).

New Jersey: Phillipsburg, June 14 to August 2 (J. W. Green).

New Mexico: Cloudcroft, August 4 (Knaus).

New York: Ithaca, July 2 (C.U.) ; Cayuga Lake, June 6 (C.U.) ; Olcott, June 5 (Dietrich) ; Crugers, June 15 (A.M.N.H.).

Nova Scotia: Truro, August 5 (Frost).

Ohio: Salineville (C.U.) ; Columbus, July 12 (Liljeblad).

Pennsylvania: Saylorsburg, July 10 (J. W. Green); Edge Hill, May 24, Delaware County, July 8, and Harrisburg, June 25 (Knull) ; Rockville, June 13 (Kirk) ; Rochester, June 25 (Miss E. W. Mank).

\section{Mordellistena suspecta Fall}

Mordellistena suspecta Fall, 1907, p. 256, Pecos, New Mexico.

\section{DESCRIPTION.-}

Hind tibiae with three short slightly oblique ridges; first joint of hind tarsus with three, second with two not very oblique ridges.

Black, linear, pubescence cinereous with sparse fuscous hairs, which on the elytra tend to arrange themselves in longitudinal lines, giving a faint vittate appearance. Last joint of maxillary palpi moderately dilated, the apical edge subequal to the inner. Antennae piceous throughout, the fourth joint three-fourths as long as the fifth. Length, 2.5-3 $\mathrm{mm}$.

Pecos (Cockerell).

Apparently most nearly related to the eastern convicta. The latter is more evidently vittate, with the front legs and base of antennae pale. (Fall)

REMARKS.-The type of $M$. suspecta has not been examined by me, and I do not wish to place the species in synonymy, but there is very little doubt that it is the same as the true $M$. convicta Leconte. It is quite evident that the first specimen of the series under the name convicta in the Leconte collection is not the actual type, since it agrees neither with Leconte's description nor with the drawing, said to have been made from the type, given by J. B. Smith in his synopsis. It is rather difficult to say what specimen Leconte had before him, for no type was designated, and the original description is, therefore, the most reliable evidence. See note under convicta.

\section{Mordellistena hirticula Smith}

Mordellistena hirticula Smith, 1883, p. 4, Texas and Louisiana.

Description.-Posterior tibiae with three ridges, the subapical one not included; first segment of posterior tarsi with three and second with two ridges.

Body black, elytra fuscous, densely covered with pale cinereous pubescence, except a scutellar space, a narrow median and a somewhat broader subapical fascia which are naked; the median fascia in one of the specimens is incomplete; beneath the body is clothed with rather coarse and long hairs. $3 \frac{1}{2}$ to $4 . \mathrm{mm}$.

Texas, La. 2 specimens, 14 and 15. 
Obviously distinct from all other species by the arrangement of the pubescence and markings. (Smith)

Remarks.-Of the above types, No. 14 is in the United States National Museum, and No. 15 in the Carnegie Museum. Both specimens have been examined by me; they differ somewhat in markings. No. 14 has the head and thorax black and the lateral margin of the thorax ferruginous; pubescence pale yellow; thorax with a narrow basal margin yellowish pubescent and a small streak extending upward on each side of the middle lobe; mentum and antennae pale (three segments of antennae missing); elytra with a rather large, somewhat oval, basal spot near the scutellum, a median band or fascia somewhat oblique and a little elongated near the suture, and a subapical band; antennae with the third and fourth segments very narrow, each one-fourth shorter than the fifth, sixth to eighth subequal in length, each very little shorter than the fifth; eyes large, finely granulated and hairy; legs dark rufous, with tarsal segments missing. No. 15 is somewhat like No. 14, but the midale band or fascia is broken, with only a faint shading to indicate its presence. Length, 3.5-4 mm.

This form is unlike any other species of Mordellistena.

\section{Mordellistena scalaris Helmuth}

Mordellistena scalaris Helmuth, 1864, p. 105, Illinois. J. B. Smith, 1882, pp. 89, 97. Blatchley, 1910, p. 1324.

Description.-Posterior tibiae with three short, oblique, parallel ridges and a rudiment of a fourth ridge, the subapical one not included; first segment of posterior tarsi with three and second with two ridges.

Black; mouth, anterior feet and four basal joints of antennae piceous; pubescence grayish-brown; thorax with three black clouds; each elytron with a very undulated band before the middle, beginning near the lateral margin and joining that of the other side of the scutellum, and a large oblong spot near the apex fuscous, 17 . (4 mm.). (Helmuth)

REmarks.-The species is entirely unknown to me.

\section{Mordellistena discolor (Melsheimer)}

(Pl. V, Fig. 24)

Mordclla discolor Melsheimer, 1845, p. 313, Pennsylvania.

Mordellistena discolor, Leconte, 1862, p. 51. J. B. Smith, 1882, pp. 90, 98 . Blatchley, 1910, p. 1325.

Mordellistena cinereo-fasciata Smith, 1882, pp. 90, 98.

Mordellistena wolcotti Liljeblad, 1917, p. 12.

Description.-Posterior tibiae with three ridges and sometimes with three additional, small, rudimentary ridges, subapical not included; first segment of posterior tarsi with three to five ridges; second segment with two ridges and sometimes with a rudiment of a third ridge; all ridges small and difficult to distinguish. 
Cuneiform, rather robust; head black, closely covered with silky yellowish pubescence; antennae fuscous, four basal segments ferruginous; palpi fusco-ferruginous; prothorax black, with silky yellowish pubescence; elytra with the ground color somewhat dull rufous, plainly visible near base, where it forms a rather large spot; this color elsewhere covered by yellowish pubescence which posteriorly forms streaks or points; an undulated band below middle reaching suture and lateral margin; tip and suture with silky yellowish pubescence; underside and legs nearly black with yellowish gray pubescence; anal style black.

Head finely punctured; eyes coarsely granulated and hairy; antennae long, filiform, reaching to middle of the elytra; first to fourth segments short; fifth one-fourth longer than the third and fourth combined; sixth to tenth subequal in length, each one-fourth shorter than the fifth; last segment of maxillary palpi scalene triangular, inner and apical sides about equal in length.

Pronotum one-third broader than long, finely punctured; basal angles obtuse. Elytra very little narrower than pronotum at base, finely punctured and reticulate; apex rounded; anal style long, slender.

Length: to apices of elytra, $4.5 \mathrm{~mm}$; to tip of anal style, $5.5 \mathrm{~mm}$.

REMARKS.-This species is unique in its markings and may be recognized readily by its black head and thorax and by the nearly rufous elytra, which are somewhat banded at the base, below the middle and at the apex. After examining the supposed type of this species in Melsheimer's collection, now in the Museum of Comparative Zoology and Smith's type of cinereo-fasciata, No. 999 in the United States National Museum, I found that these two and my wolcotti are identical. In the original description of discolor Melsheimer said nothing about the ridges on the posterior legs. These were first discussed by Leconte, although he mentioned only the ridges on the tibiae, which he gave as five or six. These ridges on the type are very small and difficult to distinguish. Not more than three can be said to be real ridges. Aside from these five very small ridges can be seen on the first of the posterior tarsi and two on the second joint.

Previous Records.-Pennsylvania (Melsheimer); central and southern states (Leconte); Cincinnati, Ohio (Dury); Staten Island, New York (Shoemaker); Ithaca, New York (Smith); McGregor, Iowa (Liljeblad).

Material Examined.-Kentucky : Louisville, June 22 (Soltau, U.S.N.M.). New Jersey : Westville, July 21 (Mason).

\section{Mordellistena pubescens (Fabricius)}

$$
\text { (PI. V, Fig. 26) }
$$

Mordella pubescens Fabricius, 1798, p. 127, America; idem, 1801, p. 123.

Mordcllistena pubescens, Leconte, 1862, p. 51. J. B. Smith, 1882, pp. 89, 97. Blatchley, 1910, pp. 1324, 1325.

Mordella modesta Melsheimer, 1846, p. 314. 
DESCRIPTION.-Posterior tibiae with three short, parallel, oblique ridges, and a rudiment of a fourth ridge, which sometimes is so well defined as to constitute a full ridge, subapical not included; first segment of posterior tarsi with three, second with two ridges.

Cuneiform; head black, with cinereous pubescence; mentum, antennae, and palpi testaceous; prothorax black, densely covered with cinereous pubescence, leaving three well-defined black spots, one at middle and one on each side, middle spot sometimes divided into two elongate spots; elytra black with humeral angle in certain lights more or less ferruginous, and with sericeous, cinereous pubescent markings, as follows: a narrow sutural line, a curved basal band from humeri to suture, a crossband behind middle, and tip; these pubescent marking's vary considerably and the elytra are sometimes more reddish brown than black, but, if such is the case, the space surrounded by the basal band is always black; underside black; anterior legs testaceous; middle femora black; tibiae and tarsi testaceous; posterior legs more or less dark; anal style black.

Head minutely aciculate, densely and finely punctured; eyes finely granulated and hairy; antennae subfiliform, short, reaching a little below base of elytra; third and fourth segments subequal in length, narrow; fifth to tenth subequal in length, each one-fifth longer than the fourth and a little broader; last segment of maxillary palpi rather short, securiform.

Pronotum one-third broader than long, finely punctured; hind angles obtuse; basal lobe at middle, in front of scutellum, prominent, broadly rounded.

Elytra reticulate and finely punctured; anal style moderately long.

Length: to apices of elytra, 2.25-3.25 mm.; to tip of anal style, 3.5$4.5 \mathrm{~mm}$.

REMARKS.-This species is rather prettily marked and does not resemble any other of our species of Mordellistena, although J. B. Smith placed two species, hebraica and leporina, in synonymy with it. Both of these last mentioned species are valid and cannot be closely allied to pubescens, since the antennae and palpi, as well as the color pattern, differ entirely. The present species is somewhat variable in marking's and color, ranging from black to reddish brown, but the general pattern is always about the same in specimens not mutilated or rubbed. The M. modesta in Melsheimer's collection, in the Museum of Comparative Zoology, is no doubt the same as the present species. It is by no means common, but it is more abundant than are hebraica and leporina. It is found on flowers, such as Cornus an $\mathrm{A}$ Viburnum, and appears from April to August.

Previous Records.-North America (Fabricius); central and southern states (Leconte) ; New York (Smith); southwestern Pennsylvania (Hamilton); Cincinnati, Ohio (Dury); Lawrence, Douglas County, Kansas 
(Snow); Iowa City, Iowa (Wickham); Indiana, southern third of the state (Blatchley).

Material examined.-Alabama: Chambers County (H. H. Smith, U.S.N.M.) .

Connecticut: Cornwall, June 29 (Chamberlain).

District of Columbia: Washington (U.S.N.MI.) ; Anacostia, May 7 (Myers, U.S.N.M.).

Illinois : Riverside, July 12 (Liljeblad).

Kansas: Onaga, June 3 (Knaus).

Maine: Paris and Monmouth, June 16, August 27 (Frost).

Maryland : Plummers Island, June 17, July 7 (McAtee, U.S.N.M.).

Massachusetts : Framingham, Sherborn, Natick, Essex County, and Nobscott Mountain, May 28 to June 16 (Frost).

New Jersey : Phillipsburg, August 2 (J. W. Green) ; Ridgewood, June 22 (Leonard, C.U.) ; Highlands, June 29 (Soltau, U.S.N.M.) ; Orange Mountains (Soltau, U.S.N.M.).

New York: Peekskill, April 19 (Sherman, C.U.) ; New York City, July 4 (Soltau, U.S.N.M.).

North Carolina: Asheville, May 6 (Harnach).

Pennsylvania : Inglenook, July 18 (Kirk); Enterline, July 15 (Gayton); Harrisburg, June 26 (Champlain).

Tennessee: Grassy Cove, Cumberland County, July 15 (Hubbell).

Texas : San Diego, May 18-25 (Schwarz, U.S.N.M.).

Virginia: Mount Vernon, June 17 (Chamberlain; Glencarlyn, May 30 (Knab, U.S.N.M.) ; Drummond, June 8 (Barber, U.S.N.M.).

\section{Mordellistena bihamata (Melsheimer)}

(Pl. V, Fig. 25)

Mordella bihamata Melsheimer, 1846, p. 313, Pennsylvania.

Mordellistena bihamata, Leconte, 1862, p. 51. J. B. Smith, 1882, pp. 89, 97. Blatchley, 1910, pp. 1324, 1325.

DesCRIPTION.-Posterior tibiae with three parallel, oblique ridges and a strongly marked rudiment of a fourth ridge, subapical not included; first segment of posterior tarsi with three, second with two ridges.

Linear; head black, with cinereous pubescence; antennae and palpi ferruginous; prothorax black, with the basal lateral margin more or less ferruginous, pubescence cinereous; elytra reddish brown, sometimes brown or nearly black, with humeral angle more or less reddish, and having silky yellowish pubescent spots or bands as follows: a slightly curved band from humeri downward, this sometimes connected with an elongate mark near the suture, a similar elongated mark below middle, one near suture, which sometimes is connected with a similar mark near margin (this marginal 
mark, in some specimens, extended upward and connected with the humeral band), and on the tip; underside black, with yellowish sericeous pubescence, denser on abdominal segments; anterior and middle legs ferruginous, posterior legs darker; anal style varying from black to reddish brown, pubescence gray near base, black at middle, and yellowish at tip.

Head large, finely punctured; eyes coarsely granulated and hairy; antennae filiform, in male about $2.59 \mathrm{~mm}$. long, reaching below middle of elytra, in female a little shorter, about $1.75 \mathrm{~mm}$. ; both sexes with the three basal antennal segments short; fourth a little longer than second and third segments combined, and nearly twice as broad at apex; fifth to tenth subequal in length, each as long as fourth; last segment of maxillary palpi in male securiform, with the inner and apical sides equal--longer and narrower and with inner side longer than apical in female.

Pronotum one-fourth broader than long in male, one-third broader than long in female, finely punctured; basal angles obtuse; basal lobe at middle, in front of scutellum, not very prominent but very broad and nearly truncate.

Elytra finely punctured, a little narrower than pronotum at base and tapering very little to one-fourth from tip; apex broad and nearly truncate; anal style long and slender.

Length : to apices of elytra, 3-4 mm.; to tip of anal style, 4-5.25 mm.

REMARKs.-Perfectly fresh specimens of this species are rather pretty. It is not a variety of Mordellistena pubescens, nor is it a variation of hebraica or leporina, which were placed in synonymy with pubescens. It is a good species which differs from pubescens in the color pattern, in the lack of pubescent markings on the thorax, in the more elongated spots on the elytra, and by having the antennae entirely different. Specimens with the scutellar area black have been seen from Black Mountains, North Carolina. The type of the present species has not been seen by me, and the specimens in Melsheimer's collection do not at all agree with his description, but there is no doubt that the above description, taken from specimens in my collection, will be sufficiently diagnostic for bihamata.

Previous Records.-Pennsylvania (Melsheimer); Cincinnati, Ohio (Dury); and Indiana, southern half of state (Blatchley).

Material examined.-District of Columbia : Washington, July 21 (Knab, U.S.N.M. ) .

Kentucky : Louisville, June 17 (Soltau, U.S.N.M.).

Maryland: Plummers Island, August 4 (Schwarz, U.S.N.M.) ; Montg'omery County, July 9 (A.M.N.H.).

New Jersey: Eagle Rock, July 8; Westville; Highland, July 8 (Soltau, U.S.N.M.).

New York : New York City, July 4 (Soltau, U.S.N.M.). 
North Carolina : Black Mountains, July (A.M.N.H.) ; Haywood County, July 27 (Hubbell).

Ohio: Columbus, July 19 (Liljeblad); Cincinnati, August 7 (Soltau, U.S.N.M.).

Pennsylvania : Montgomery County, July 25, and Reading, July 23 (Gerhard); Hummelstown, Portage, and Charter Oak, June 3 to August 10 (Knull).

Virginia : Fredericksburg, June 16-19 (Soltau, U.S.N.M.).

\section{Mordellistena hebraica Leconte}

(PI. V, Fig. 27)

Mordellistena hebraica Leconte, 1862, p. 51, central and southern states.

DESCRIPTION.-Posterior tibiae with three parallel, oblique ridges, and a rudiment of a fourth, the subapical one not included; first segment of posterior tarsi with three ridges, in the female also with a rudiment of a fourth; second segment with two ridges.

Subcuneiform; head in male mostly ferruginous, but vertex black, with somewhat bluish green reflections; head of female entirely black or with only mentum ferruginous; antennae and palpi ferruginous; prothorax in male ferruginous with an elongate or oval spot at middle near base, in female entirely black; elytra black with sericeous, cinereous pubescent markings as follows: a narrow sutural line, an oblique basal band from humeral angle to suture, a rather broad transverse band behind middle, and a narrow submarginal line connecting basal and middle bands and enclosing an elongate black spot on each elytron at middle, and apex; underside black, with cinereous pubescence; anterior and middle pair of legs ferruginous; posterior legs with femora black, tibiae and tarsi fuscous, sometimes ferruginous; anal style black, rarely lighter at tip, with cinereous pubescence near base.

Head finely, rather densely punctured; eyes finely granulated, hairy; antennae filiform, very long, reaching nearly to middle of elytra; third segment shortest, about one-third shorter than fourth; first three segments about as long as fourth and fifth combined; fourth to tenth subequal in length, but fourth much the narrowest at base; last segment of maxillary palpi elongate, with inner side about one-fifth longer than apical.

Pronotum fully one-third broader than long; surface rather coarsely punctured; hind angles subacute; basal lobe at middle prominent, broad.

Elytra very little narrower than pronotum, tip somewhat pointed, surface reticulate and more coarsely punctured; anal style long and slender.

Length : to apices of elytra, $2.5-3.25 \mathrm{~mm}$.; to tip of anal style, $3.5-4.5 \mathrm{~mm}$.

REMARKs.-This species, although placed in synonymy under pubescens by J. B. Smith (1882:97), is without doubt valid and cannot be at all allied 
to that species. It differs from pubescens in its much longer antennae and in having the fourth antennal segment much longer than the third; the last segment of the maxillary palpi is much longer than in the other species. The pubescent markings on the elytra also readily separate the two forms, for hebraica has a submarginal line connecting the basal and middle bands. This species differs from leporina in having the tip of the elytra with cinereous pubescence, whereas in the other form the pubescence occurs in a subapical band one-fourth the distance from the apex. A specimen from Pittsburgh has the elytra dark ferruginous, but the markings are the same, although the middle band is a little broader. The supposed type or first specimen in the Leconte collection, in the Museum of Comparative Zoology, is a male from Columbus, Texas, which agrees with the above description.

Previous RECORDs.-Central and southern states (Leconte).

Material examined.-Alabama: Langdale (H. H. Smith, U.S.N.M.) ; Clay County (H. H. Smith, U.S.N.M.).

Arizona: southwestern part (Palm, A.M.N.H.).

District of Columbia : Washington (U.S.N.M.).

Georgia : no locality (Ulke, U.S.N.M.).

Illinois: Mount Carmel, July 2 (I.S.N.H.S.) ; Makanda, June 4 (I.U.) ; Villa Ridge, June 4 (McElfrech, I.U.).

Indiana: Crawford County, June 24 (Blatchley).

Kentucky: Wickliffe (Hary, I.U.).

Maryland: Plummers Island, June 30 (Fisher) and July 3 (Barber, U.S.N.M) ; Jacksons Island, June 17 (Shannon and Barber, U.S.N.M.).

Michigan : Ann Arbor, Washtenaw County, June 28 (Hubbell).

Missouri: St. Louis, July 4 (Liljeblad).

New Hampshire: Rumney, July 25, on wild cherry (Darlington).

North Carolina: Southern Pines, May 25 (Manee); Black Mountains, July (A.M.N.H.) ; Crestmont, Haywood County, July 25 (Hubbell).

Pennsylvania: Pittsburgh and Bloomfield, June 3 (Knull).

Virginia: Fredericksburg, June 6-15 (Richardson) ; Rosslyn, August 7 (H. H. Smith, U.S.N.M.).

\section{Mordellistena liturata (Melsheimer)}

(Pl. V, Fig. 28)

Mordella liturata Melsheimer, 1845, p. 314, Pennsylvania.

Mordellistena liturata, Leconte, 1862, p. 51. J. B. Smith, 1882, pp. 89, 97. Blatchley, 1910, pp. 1324, 1325.

Description.-Posterior tibiae with three parallel, oblique ridges and rudiment of fourth, which is well-marked in female, subapical not included; first segment of posterior tarsi with three and second with two ridges.

Cuneiform; head fusco-luteous with cinereous pubescence; antennae and 
palpi luteous; prothorax with color like that of head, but with faint indication of three basal clouds; elytra usually darker brown one-third from base and with markings of silky yellowish pubescence as follows: an oblique band from humerus to suture, a rather large oblique spot at middle, a broad spot at apex, and a narrow sutural line (these pubescent areas are rather difficult to distinguish in some specimens); underside and legs rufo-testaceous; abdomen densely covered with yellowish gray pubescence; anal style like elytra in color.

Head minutely aciculate and finely punctured; eyes rather coarsely granulated, hairy; antennae subfiliform, a little shorter in female; third segment shortest, one-fourth shorter than fourth; fifth much longer and broader than fourth and one-fifth longer than sixth; sixth to tenth subequal in length; last segment of maxillary palpi in male scalene triangular, with inner and apical sides about equal in length, in female more elongate with apical side shorter than inner.

Pronotum one-third broader than long, its surface like that of head; basal angles obtuse ; basal lobe at middle, in front of scutellum, broadly rounded.

Elytra a little narrower than pronotum at base, finely punctured, apex narrowly rounded; anal style long and slender.

Length: to apices of elytra, $2.5-3 \mathrm{~mm}$; t to tip of anal style, $3.5-4.5 \mathrm{~mm}$.

REMARKs.- - This species is rather easy to identify, after the ridges have been examined; it is pale and has three, somewhat oblique, pubescent markings on the elytra, although the latter are sometimes difficult to distinguish in old and greasy specimens. The middle marking's vary somewhat in shape and size. In certain lights the elytra seem to be darker one-third from base, and in such circumstances the markings are very well defined. The supposed type in the Melsheimer collection in the Museum of Comparative Zoology has been examined by me, and it agrees with the above description. The specimens appear from May to July.

Previous ReCords.-Pennsylvania (Melsheimer); central and southern states (Leconte); southwestern Pennsylvania (Hamilton); Cincinnati, Ohio (Dury) ; Knox and Posey counties, Indiana (Blatchley) ; Jamaica, New York (Nicolay); Aqueduct, New York (Shoemaker); Staten Island, New York (Davis).

Material EXAmined.-Alabama: Oak Grove, June 11 (Soltau, U.S.N.M.).

Georgia: Dahlonega, June 7 (U.M.).

Illinois : Quincy, June 11, July 12 (I.U.).

Kansas : Douglas County, July (Tucker, K.U.).

Maryland: Cabin John Br. (H. Barber, U.S.N.M.) ; Plummers Island, July 15 (Knab), June 23 (Barber), July 12 (Schwarz, U.S.N.M.).

Michigan : Pigeon, Huron County, June 29 (Hussey).

New Jersey : Phillipsburg, July 19, August 2 (J. W. Green) ; Eagle Rock, 
July 8 (Mason) ; Woodbury, July 7 (Crew coll., C.U.) ; Highlands, June 29 (Soltau, U.S.N.M.).

New York: Flatbush, Long Island, July 10 (U.S.N.M.) ; New York City, July 4 (Soltau, U.S.N.M.).

North Carolina: Southern Pines, May 25 (Manee).

Ohio : Columbus, July 16 (Liljeblad).

Pennsylvania: Point Pleasant, July 26 (J. W. Green) ; Angora, June 25 and Manayunk, June 16 (Mason) ; Hummelstown, June 16 (Knull) ; Marietta, July 12; Inglenook and Jeannette, July 18 (Kirk).

Virginia : Fredericksburg, June 15 (Richardson, U.S.N.M.) ; Glencarlyn, July 14 (Heidemann, U.S.N.M.) ; L. Drummond, June 8 ( H. S. Barber, U.S.N.M.).

\section{Mordellistena pulchra Liljeblad}

(Pl. V, Figs. 29 and 30)

Mordellistena pulchra Liljeblad, 1917, p. 12, Bowmanville, Illinois (female); 1921, pp. 185, 196, Edgebrook, Illinois (male).

DESCRIPTION.-Posterior tibiae with three oblique ridges, upper less strongly indicated and a little more oblique, subapical not included; first segment of posterior tarsi with four, second with three small ridges. Some male specimens have the first segment of the posterior tarsi with three ridges and a rudiment of a fourth, and the second segment with two ridges and sometimes with a rudiment of a third ridge.

Nearly parallel, more robust in female; head ferruginous, sometimes more rufous; antennal segments at apex and last segment of maxillary palpi rather dark brown; prothorax ferruginous with a dark median streak from base to middle (this is sometimes absent) and with basal margin more or less black; elytra black, with fine, rather long, cinereous pubescence; in male with a rufous vitta from base nearly to apex, but in many specimens this is only visible near base; the female has the vitta usually much broader; legs and undersurface more or less ferruginous, but usually darker in female; anal style black, with ferruginous base.

Head rather large, minutely aciculate and punctured; eyes finely granulated, hairy; antennae short, filiform, not reaching base of thorax; third segment one-fourth longer than fourth in male, equal in length in female; fifth segment one-third longer than fourth in male; sixth to tenth subequal in length, each one-fourth shorter than fifth; last segment of maxillary palpi securiform.

Pronotum one-third broader than long, finely aciculate and more coarsely punctured; hind angles obtuse, nearly acute in male; basal lobe at middle, in front of scutellum, broadly rounded.

Elytra a little narrower than pronotum at base, surface finely punctured; 
anal style long and slender in male, shorter in female; male with long setae on inner side of anterior femora.

Length: to apices of elytra, $3.5 \mathrm{~mm}$; t to tip of anal style, $4.75 \mathrm{~mm}$.

Remarks.-The female of this species somewhat resembles that of $M$. attenuata in respect to the elytral vittae, but attenuata is broader and differs entirely in the ridges and somewhat in color. The present form is readily recognized by the ferruginous or nearly rufous vittae on the elytra, especially in the female. It has been taken on the flowers of Helianthus. It is rather abundant around Chicago, Illinois, but undoubtedly has been overlooked on account of its habits, as it attaches itself firmly to the flowers and can scarcely be shaken off. It appears in August and September. The type is in the collection of the Museum of Zoology, University of Michigan (Liljeblad coll.).

Previous Reconds.-Bowmanville and Edgebrook, Illinois (Liljeblad). Material examined.-Arkansas : Fayetteville, August 15 (Knaus).

Illinois: Palos Park, Willow Springs, August and September (Gerhard, Wolcott, Selinger, and Liljeblad) and no locality (I.U.).

Kansas: Salina and Benedict, September (Knaus).

Michigan: Washtenaw County, August 5 (Hatch).

Pennsylvania : Jeannette, August (Knull).

\section{Mordellistena caliginosa, new species}

Trpe.-From Clear Lake, Utah. A male, collected on July 2 by H. F. Wickham; in the collection of the Museum of Zoology, University of Michigan (Liljeblad coll.).

Allotrpe.-A female, same data as type; in the collection of $H$. F. Wickham.

Description.-Posterior tibiae with three short, parallel ridges, subapical not included; first segment of posterior tarsi with three, second with two ridges.

Subcuneate, rather broad; head and thorax fusco-ferruginous, covered with yellowish gray pubescence; apical segments of antennae a little more fuscous.

Elytra with ground color fuscous brown, densely covered with yellowish brown pubescence, more silvery gray in female; underside same as elytra; anterior legs pale; otherwise like $M$. blandula, except that the basal lobe of the thorax in front of the scutellum is truncate.

Length : to apices of elytra, 3.5-4 mm.; to tip of anal style, $4.5-5.25 \mathrm{~mm}$.

REMARKs.-This species somewhat resembles $M$. blandula, but the elytral ground color and underside in that species are very pale ferruginous, whereas in caliginosa they are very dark or nearly black, and the basal lobe at the middle of the thorax is truncate. 
Mordellistena tantula, new species

(Pl. V, Fig. 19)

Type.-From Indo, California. A male (?), collected on August 19 by H. F. Wickham; in the Museum of Zoology, University of Michigan (Liljeblad coll.).

PARAtype-A female (?), same data as type; in the collection of $\mathrm{H}$. F. Wickham.

DesCRIPTION.-Posterior tibiae with three short, parallel, oblique ridges, subapical not included; first segment of posterior tarsi with three, second with two ridges.

Elongate oval; head dark brown, front testaceous; antennae and palpi fuscous; thorax, elytra, and underside black, covered with brownish gray pubescence; anterior and middle femora and tibiae pale, tarsi fuscous; posterior legs reddish brown; anal style black.

Head large, minutely aciculate and punctured; antennae short, scarcely reaching base of thorax; third and fourth segments subequal in length, uarrow; fifth to tenth about equal in length, each much broader at apex; last segment of maxillary palpi elongate, inner side nearly twice as long as apical; eyes moderately granulated, hairy.

Pronotum about as broad as long, finely aciculate and punctured, basal angle acute, basal lobe at middle, in front of scutellum, well defined and rounded.

Elytra oval, finely aciculate and punctured; anal style short.

Length: to apices of elytra, $2.5-2.75 \mathrm{~mm}$; to tip of anal style, $2.75-$ $3.25 \mathrm{~mm}$.

REMARKs.-This short, oval species does not resemble any other in this group. After the ridges have been examined, it is readily recognized by the short antennae, the short anal style, and the elongated apical segment of the maxillary palpi.

\section{Mordellistena palmi, new species}

Type.-From Prescott, Arizona. Collected by Charles Palm and named in his honor ; in the collection of the American Museum of Natural History.

Paratypes.-Two specimens, same data as type; one paratype in the Museum of Zoology, University of Michigan (Liljeblad coll.).

Description.-Posterior tibiae with three small, somewhat oblique ridges, subapical not included; first segment of posterior tarsi with three, second with two ridges.

Moderately elongate; head and thorax testaceous, the latter with the narrow basal margin black, covered with fine grayish pubescence; maxillary palpi testaceous, except at tip, which is fuscous; four basal segments of antennae testaceous; fifth to eleventh segments fuscous at tip; elytra fuscous, with base, humeri, and sides to near middle testaceous, heavily 
covered with rather coarse, silvery gray pubescence; underside fusco-ferruginous, with abdomen nearly black; legs more or less testaceous; anal style nearly black.

Head minutely aciculate and punctured; eyes moderately large, hairy, with a narrow margin, scarcely or not at all emarginate; antennae filiform, slightly widened toward apex, reaching to base of thorax; all segments nearly equal in length, except first and eleventh, which are the longest; third and fourth segments narrow ; last segment of maxillary palpi elongate, broadened toward apex, with inner angle not very sharply defined and outer side shorter than inner.

Pronotum about one-fourth broader than long, a little broader than elytra at base, evenly rounded to apex; hind angles obtuse; surface finely aciculate and punctured.

Elytra a little narrowed toward apex; surface like pronotum; anal style moderately long, pointed.

Length : to apices of elytra, $3.5 \mathrm{~mm}$; to tip of anal style, $4.5 \mathrm{~mm}$.; width, $1.4 \mathrm{~mm}$.

REmaris.-This species does not resemble any of the other species of Mordellistena. It is readily recognized by its uniform testaceous color on liead and thorax and by its dark elytra, with base and humeral testaceous.

\section{Mordellistena blandula, new species}

\section{(Pl. V, Fig. 18)}

Type--From Salton, California. A male, collected at an elevation of 265 feet on August 20 by H. F. Wickham; in the Museum of Zoology, University of Michigan (Liljeblad coll.).

Allotype.-A female, same data as type; in the collection of $\mathrm{H}$. F. Wickham.

Description.-Posterior tibiae with three short, parallel ridges, subapical not included, female with rudiment of fourth ; first segment of posterior tarsi with three, second with two ridges, all short.

Subcuneate, rather broad; ground color entirely pale ferruginous, covered with fine, sericeous, yellowish white pubescence; antennae with segments five to eleven fuscous.

Head large, finely punctured; antennae with all segments nearly equal in length, third and fourth segments narrow, fifth a little broader at tip; sixth segment broadest; last segment of maxillary palpi elongate, scalene triangular, inner side longer than apical; eyes coarsely granulated, hairy.

Pronotum one-third broader than long, sides gradually rounded from base to apex when viewed from above; basal angles subacute; basal lobe at middle, in front of scutellum, broad, nearly truncate.

Elytra a little narrower than pronotum, finely punctured; anal style short. 
Length: to apices of elytra, 3.5-4 mm.; to tip of anal style, $4.5-5.25 \mathrm{~mm}$.

REMARKs.- This species is rather broad, uniformly pale reddish in color, with rather coarse yellowish white pubescence; the color, antennae, and palpi readily separate this western Mordellistena from all the other species.

\section{Mordellistena ambusta Leconte}

(P1. V, Fig. 20)

Mordellistena ambusta Leconte, 1862, p. 50, southern states. J. B. Smith, 1882, pp. 88, 96. Blatchley, 1910, pp. 1322, 1323.

DescriPtion.-Posterior tibiae with three strongly marked, oblique ridges, subapical not included; first segment of posterior tarsi with three, second with two ridges; ridges on tibiae longer and more oblique than usual. There is also a rudimentary ridge on the tibiae and first segment of tarsi, especially of female.

Subcuneate, more parallel in female; entirely fusco-ferruginous or dark reddish brown; head usually a little lighter, covered with silky yellowish brown pubescence, a little longer and denser on elytra, where it forms a slight indication of a sutural line; underside a little darker.

Head rather large, densely and minutely punctured; eyes moderately large, finely granulated, hairy; antennae long, subfiliform, reaching below thorax; third and fourth segments small; fifth much broader at apex and nearly as long as third and fourth segments combined; sixth to tenth subequal in length to fifth; last segment of maxillary palpi elongate scalene triangular.

Pronotum one-third broader than long, its surface aciculate and with fine punctures; basal angles obtuse; basal lobe broadly rounded at middle in front of scutellum. Scutellum rather large, rounded at tip.

Elytra reticulate with somewhat large, deep punctures; apex rounded in male, subtruncate in female, with distinct margin; anal style short.

Length : to apices of elytra, 3.5-4.5 mm.; to tip of anal style, 4-5 mm.

REMARKs.-This species has always been rather easy to distinguish from the others in this group by the color and by the longer and more strongly oblique ridges on the tibiae. A slight difference in color and in the segments of the antennae occurs in some specimens, but not enough to justify their separation. The male is usually lighter in color than the female and has the suture more closely covered with bright yellowish pubescence, and the antennal segments are narrower and more parallel-sided. Two specimens in the Leconte collection, in the Museum of Comparative Zoology, may be taken as the types of this species; the first is a female and the second a male; both agree with the above description.

Previous REcords.- Southern states (Leconte); New York (Smith); Cincinnati, Ohio (Dury); Harrington, Canada (Hague); southwestern 
Pennsylvania (Hamilton) ; and Vigo, Knox, and Crawford counties, Indiana (Blatchley).

Material examined.-Alabama: Pyzilon, Clay County (H. H. Smith, U.S.N.M.) .

Arizona: southwestern part (Palm, A.M.N.H.).

District of Columbia: Washington, June 26 (Hubbard and Schwarz), July 12 (Barber, U.S.N.M.).

Georgia: Spring' Creek, Decatur County, June 7-23 (Bradley, C.U.) ; no locality (J. B. Smith, U.S.N.M.).

Illinois : Palos Park, Cook County, July 20 (Liljeblad) ; Edgebrook, July 21 (Harnach) ; Aldridge, August 11 (Hart and Shiga) ; Springfield, July 2 (Hart, I.U.).

Indiana: Mineral Springs, July 4 (Liljeblad).

Kansas : Lawrence, July (K.U.).

Kentucky : Louisville, June 22 (Soltau, U.S.N.M.).

Maryland: Plummers Island, June 21 (Knab), August 4 (Schwarz, U.S.N.M.) .

New Jersey : Phillipsburg, August 14 (J. W. Green).

New York: Ithaca, July 19 (C.U.) ; Olcott, July 10 (Dietrich); Long Beach, Long Island (A.M.N.H.).

North Carolina: Tryon, May 30 (W. S. Fisher, U.S.N.M.).

Ohio : Cincinnati, June 26 (Soltau, U.S.N.M.).

Pennsylvania: Linglestown, June 18 (W. S. Fisher, U.S.N.M.) ; Shiremanstown, June 3, reared in Hickory (W. S. Fisher, U.S.N.M.) ; Hummelstown, July 12 (Knull) ; Canonsburg, July 12, August 6 (Akerlind) ; Inglenook, July 18 (Kirk).

Virginia: Rosslyn, August 7 (H. H. Smith, U.S.N.M.) ; L. Drummond, June 8 (H. S. Barber, U.S.N.M.).

West Virginia: Berkeley (Hubbard and Schwarz, U.S.N.M.).

\section{Mordellistena fuscipennis (Melsheimer)}

(Pl. VI, Fig. 1)

Mordella fuscipennis Melsheimer, 1845, p. 314, Pennsylvania.

Mordellistena fuscipennis, Leconte, 1862, p. 50. J. B. Smith, 1882, pp. 88, 95.

Mordellistena pityptera Leconte, 1862, p. 51. J. B. Smith, 1882, pp. 89, 97.

DESCRIPTION.-

Rufous; elytra fuscous, 2 L. Long. Pennsylvania (fuscipennis, Melsheimer).

Hind tibiae with four oblique ridges besides the subapical one. First joint of hind tarsi with three, second with two, third with two, all the ridges very strongly marked. Ferruginous, elytra black, with the humeri indistinctly ferruginous, and the suture and lateral margin narrowly pale sericeous, 23. Pa. (pityptera). (Leconte)

REMarks.-Both fuscipennis Melsheimer and pityptera Leconte were described from Pennsylvania and the two, according to the descriptions, do 
not seem to differ very much except in the ridges. According to Leconte and Smith, fuscipennis should have three ridges on the tibiae, three on the first segment of the tarsi and two on the second segment, and pityptera should have four on the tibiae, three on the first segment of the tarsi, two on the second segment, and two on the third. The supposed type of this species, a female in Melsheimer's collection in the Museum of Comparative Zoology, has been examined by me. It has three ridges and a rudimentary fourth one on the tibiae, three and a rudiment on the first segment of the hind tarsi, two on the second segment, and only a rudiment on the third. Leconte's type of pityptera has four ridges on the tibiae, four on the first segment of the tarsi, two and a rudiment on the second segment and two small ones on the third.

The several specimens that I have examined all seem to agree fairly well in color with the two descriptions, but no specimen has a real, full, fourth ridge on the posterior tibiae, but at most a more or less rudimentary one. Some specimens have a rudimentary fourth ridge on the first segment of the posterior tarsi, some have only one small ridge on the third segment, and others have a second rudimentary ridge, and sometimes these rudimentary ridges differ on the two legs. The color also varies to some extent, for some specimens do not have the lateral margin pale.

From these observations I am convinced that some allowance must be made for variations. J. B. Smith, in his synoptic description of pityptera, did not say that the thorax has a dark spot at the middle, but his plate plainly shows such a spot. Furthermore, he said : "Margin narrowly pale," but no such thing is shown in the figure. The figure of the tarsal segments shows four ridges on the first segment, two on the second, and none on the third, but in his table Smith said that there are three ridges on the first segment, two on the second, and two on the third. In consequence, I cannot separate pityptera from fuscipennis.

REDESCRIPTION.-Posterior tibiae with three well-marked, oblique, parallel ridges and in some specimens rudiment of a fourth, subapical not included; first segment of posterior tarsi with three ridges, second with two, third with one ridge and sometimes rudiment of a second.

Elongate, nearly parallel to near apex; head and thorax ferruginous, sometimes with dark cloud at base; antennae with four basal segments ferruginous; fifth to eleventh segment black; palpi ferruginous; elytra black or brownish black, with base, subhumeral angles, suture, and sometimes lateral margins more or less ferruginous and with golden yellow, sericeous pubescence; underside ferruginous, sides of pectus and metasternum somewhat blackish; legs more or less ferruginous; anal style ferruginous, with dark shading in some specimens.

Head rather large, minutely punctured; antennae subfiliform in male, 
slightly serrate in female, a little longer than head and thorax; male with third and fourth segments about equal in length; fifth a little longer than third and fourth combined; sixth and seventh each equal in length to fifth; eighth to tenth each a little shorter; eleventh oval; female with antennae shorter, segments shorter, broader, and more rounded on inner side ; last segment of maxillary palpi scalene.

Pronotum a little broader than elytra at base, evenly rounded, but broadest at middle and finely punctured; sparsely covered with black and yellowish pubescence.

Elytra rather widely separated at apex, surface more coarsely punctured; anal style short and pointed.

Length: to apices of elytra, $3.5-5 \mathrm{~mm}$.; to tip of anal style, $4.5-6.5 \mathrm{~mm}$.

This species is easily recognized by the more or less ferruginous head and thorax, the nearly black or dark brown elytra having the suture, the lateral margin and a humeral or subhumeral spot with silky golden yellow pubescence. The color is somewhat variable, some specimens being darker than others, and the ridges also vary a great deal in regard to rudimentary spinules. The insect is rather scarce.

Previous Records.-Pennsylvania (Melsheimer and Leconte); Kentucky (Leconte) ; central states and New York (Smith) ; Catskill Mountains, New York (Nicolay); and southwestern Pennsylvania (Hamilton).

Material examined.-Illinois : McHenry, July 31 (I.U.).

Maine: Cape Rocier, August 24 (Darlington).

Michigan : Gogebic County (U.M.).

New Hampshire: Rumney, July 24-28 (Darling'ton).

Nova Scotia: Portaupique, August 5 (Frost).

Ontario : Toronto, July 10 (Crew coll., C.U.).

Pennsylvania: Tioga County (Liljeblad coll.); Philadelphia, July 10 (Mason).

Virginia : Falls Church, July 20 (Cushman, U.S.N.M.).

\section{Mordellistena badia, new species}

Type.-From Kansas. A male, collected by T. B. Ashton; in the collection of Purdue University.

Description.-Posterior tibiae with three ridges, subapical not included; first segment of posterior tarsi with three ridges, second with two, and third with one ridge and rudiment of a second; all rather short and parallel.

Nearly linear; head very dark reddish brown or nearly black, sparsely covered with sericeous, yellowish pubescence; antennae testaceous; maxillary palpi testaceous; eyes black; thorax dark reddish brown or nearly black, with bluish green luster, sparsely covered with sericeous, yellowish pubescence; elytra castaneous, a little darker toward apex, sparingly covered with 
rather coarse, stiff, yellowish pubescence; underside a little lighter than elytra and with a slight appearance of bluish green reflections in certain lights; sides of metasternum darker; legs testaceous; anal style castaneous, finely pubescent.

Head large, nearly as wide as elytra at base, minutely punctured; antennae filiform; first and second segments equal in length; third and fourth about equal in length, each one-third shorter and much narrower than second; fifth to tenth slightly decreasing in length, fifth a little longer than third and fourth combined; eleventh oval, as long as tenth; maxillary palpi with last segment scalene triangular; eyes coarsely granulated.

Pronotum rather convex, finely punctured, a little broader than elytra at base, rounded and slightly converging toward apex, with a faint impression each side in front of scutellum, base at middle truncate or very feebly rounded; scutellum triangular.

Elytra nearly parallel, more coarsely punctured; underside moderately punctured but more densely and coarsely on sides of metasternum; anal style long and slender.

Length: to apices of elytra, $3.75 \mathrm{~mm}$.; to tip of anal style, $4.25 \mathrm{~mm}$; breadth, $1.25 \mathrm{~mm}$.

REMARKs.- This species is somewhat unlike all other North American Mordellistenae and can easily be recognized by the ridges of the posterior legs and by the color of the head, thorax, and elytra.

\section{Mordellistena singularis Smith}

Mordellistena singularis Smith, 1882, pp. 88, 96, Georgia. Blatchley, 1910, p. 1322.

DESCRIPTION.-Posterior tibiae with three short oblique ridges, the subapical one not included; first segment of posterior tarsi with three, second with two, and third with two oblique ridges.

All the ridges strongly marked; ferruginous, elytra black; pubescence fine and dark. $5 \mathrm{~mm}$; ; Georgia.

The figure shows the combination of tibial and tarsal ridges peculiar to this species only. Well marked by the uniform ferruginous color and the deep black elytra. One specimen only, Georgia; Coll. Dr. Horn. (Smith)

REMarks.-The type has not been located, and the species is entirely unknown to me.

\section{Mordellistena unicolor Leconte}

(PI. VI, Fig. 8)

Mordellistena unicolor Leconte, 1862, p. 50, central, southern, and western states. J. B.

Smith, 1882, pp. 88, 96. Blatchley, 1910, pp. 1322, 1323.

DESCRIPTION.-Posterior tibiae with three slightly oblique, parallel ridges, subapical not included; first segment of posterior tarsi with four, second with two ridges. 
Nearly parallel; entirely black, rather densely covered with brownish yellow or grayish brown pubescence.

Head moderately large, finely and densely punctured; eyes finely granulated, hairy; antennae short, reaching to a little below middle of thorax; fourth to tenth segments serrate; first three segments small, about equal in length; fourth a little longer and broader than third; fifth and sixth subequal in length, each nearly twice as broad as third; seventh to tenth each a little shorter than sixth; last segment of maxillary palpi scalene triangular in male, elongate and securiform in female.

Pronotum one-fourth broader than long, finely punctured; posterior angles acute; basal lobe at middle, in front of scutellum, broad, slightly emarginate.

Elytra nearly parallel to near apex, which is rounded and with distinct margin; surface finely reticulate and with fine raised punctures; anal style long and slender.

Length : to apices of elytra, $4.5 \mathrm{~mm}$.; to tip of anal style, 5-6 $\mathrm{mm}$.

REMARKS.- This is one of the species that has puzzled many collectors on account of its uniform dark color, which is common in many of the species of Mordellini. It is, however, comparatively easy to distinguish this species by its ridges and by the antennal segments and maxillary palpi. The antennae are short and rather broad from the fourth segment to the tip and are about the same in both sexes, but the last segment of the maxillary palpi differs in the two sexes as mentioned above. J. B. Smith said that he collected a good series from Dakota, which varied from black to pale yellow. This is doubtful, as no species of Mordellistena has that much variation in color; the yellow form must belong somewhere else. Fall, in his note under $M$. sericans, said that unicolor has the posterior third tarsal segments with two ridges. If such is the case, which I question, Leconte, Smith, and Blatchley are wrong in their accounts of this species.

The supposed type or first specimen in the Leconte collection, now in the Museum of Comparative Zoology, is not what was described as unicolor. I cannot be persuaded that Leconte, while constructing his synopsis (1862), made such an error with regard to his species as to forget to take notice of the ridges on the third segment of the posterior tarsi, or that Smith (1882: 88), who is known to have studied Leconte's types, did not observe these ridges in his synopsis, or that later, Blatchley, in his Coleoptera of Indiana, did not correctly determine their number and position. Aside from this, I do not believe that Leconte would have used the name unicolor for a species with two colors. The second specimen in the Leconte collection is no doubt nearer the description, but this individual is, unfortunately, without tarsi. Specimens nos. 1, 3, and 9 are like Mordellistena versa Liljeblad, and nos. $4-8$ are of other different forms. In view of the above facts, I am 
convinced that the first specimen in Leconte's collection under the name of unicolor is not the specimen decribed by him.

\section{Mordellistena marginalis (Say)}

Mordella marginalis Say, 1824, p. 278, Pennsylvania; 1859, p. 165.

Mordellistena marginalis Leconte, 1862, p. 50. J. B. Smith, 1882, pp. 88, 96. Blatchley, 1910, p. 1322.

DESCRIPTION.-Posterior tibiae with three short, oblique, parallel ridges, the subapical one not included; first segment of posterior tarsi with four ridges and in some females with a rudiment of a fifth; second segment with two ridges.

Black; head before and thorax dull rufous.

Inhabits Pennsylvania.

Hypostoma and anterior part of the front dull yellow-rufous; antennae black: thorax dull yellow-rufous, with a black quadrate oblong spot extending from the middle to the scutel, and another at each lateral angle; elytra immaculate: beneath dull golden sericeous. Length more than three-twentieths of an inch. (Say)

Remarks.-This species is perhaps most nearly allied to Mordellistena cervicalis Leconte, which may be only a variation of the present species, as the ridges and a slight variation in color appear to be the only differences. Say did not mention any ridges, which were added to the description by Leconte thirty-eight years later, nor did he mention any difference in the sexes; perhaps he had only one sex. The series at hand for examination shows a little difference in the color as well as in the ridges, and the females agree exactly with the above description.

Previous Records.-Pennsylvania (Say); central states (Leconte and Smith) ; Orange Mountains, New Jersey (Smith) ; Cincinnati, Ohio (Dury); New York state (Nicolay) ; Colorado (Wickham) ; Ames, Iowa (Osborn list, Wickham); Camp San Saba, Texas (Wincheel) ; southwestern Pennsylvania (Hamilton); and Indiana (Blatchley).

Material EXAMined.-Illinois : northern part (Peabody coll., I.U.) ; Willow Springs, August 8 (Liljeblad); Fort Sheridan, August 14 (Wolcott and Liljeblad); Edgebrook, August 17, September 6 (Liljeblad); Palos Park, Cook County, August 4 (Gerhard), September 4 (Liljeblad); Bowmanville, August 1 (Liljeblad).

Indiana: Hessville, August 22 (Liljeblad).

Kansas : Sumner County (U.S.N.M.).

Manitoba: Aweme, June 26 (Criddle).

Maryland: Plummers Island, September 4 (Schwarz).

Massachusetts: Monterey, August 1 (Frost); Framingham, Sherborn, and Malden, August 12-25 (Frost).

New Brunswick : Penobsquis, July 29 (Frost). 
New Jersey: Westville, August 16 (J. W. Green); Woodbury, June 7 (Mason).

North Carolina: Valley of Black Mountains, August 6 (Beutenmuller, A.M.N.H.).

Ohio: Columbus, July 12-22 (Liljeblad) ; Salineville (C.U.).

Pennsylvania : Pocono Lake, August 31 (J. W. Green) ; Delaware County, June 20 (J. W. Green) ; Chester County, June 20 (Mason).

Texas : no locality (Palm, A.M.N.H.).

\section{Mordellistena divisa Leconte}

(Pl. VI, Fig. 13)

Mordellistena divisa Leconte, 1859, p. 17, Platte River; 1862, p. 51. Fall, 1907, p. 257. Blatchley, 1910, pp. 1322, 1323.

Description.-Posterior tibiae with three oblique, parallel ridges, subapical not included; first segment of posterior tarsi with four, second with two ridges.

Cuneate; black with head and thorax partly rufo-testaceous, sometimes more yellow and somewhat cloudy along basal margin; antennae and palpi rufo-testaceous; prothorax with basal half black, apical half rufo-testaceous (in normal specimens the black outline is very sharply defined and bisinuate, and in some females the entire thorax is black or with only a small margin rufo-testaceous); elytra black, covered with dense, silky, brownish yellow pubescence, sometimes more silvery; some specimens with a rather wellmarked dark pubescent vitta extending from humeral angle obliquely downward to one-fourth distance from apex; underside black with cinereous pubescence; anterior legs, middle femora, and tibiae rufo-testaceous; anal style black.

Head large, nearly as broad as elytra at base, very minutely aciculate and rather densely and finely punctured; eyes normal, finely granulated, not hairy; antennae short, reaching to middle of thorax; third and fourth segments triangular, equal in length, each a little shorter than fifth, which is longest; sixth to tenth each subequal in length and a little shorter than fourth; last segment of maxillary palpi scalene triangular, narrower in female.

Pronotum one-third broader than long, broadest a little before base; surface minutely aciculate and finely punctured; basal angles obtuse, basal lobe broadly rounded at middle in front of scutellum; scutellum triangular, rather broad at tip.

Elytra more cuneate in male, nearly parallel in female; surface somewhat reticulate and finely punctured; apex rounded; anal style rather long and pointed in male, shorter in female.

Length: to apices of elytra, $2.75-3.75 \mathrm{~mm}$; to tip of anal style, $3.75-5$ $\mathrm{mm}$. 
Remarks.-This species, when freshly captured, is rather pretty; the shining pubescence on the black ground color attracts attention at once, as does the sharp, distinct demarcation of the colors on the thorax. It was placed by J. B. Smith as a synonym of marginalis, but the two forms are distinct, differing in color as well as in the antennal segments. The supposed type in the Leconte collection, in the Museum of Comparative Zoology, has been examined by me; it agrees with the above description. The species is not very rare; I have taken a number of specimens near Chicago, Illinois.

Previous Records.-Platte River (Leconte) ; Pecos, New Mexico (Cockerell); and Lake County, Indiana (Blatchley).

Material ExAmined.-Arizona : no locality (Knaus).

Colorado: Denver, August 24 (Soltau, U.S.N.M.).

Illinois: Waterman, August; Normal, October 1-10; Paloma; Vandalia, September 24 (I.U.) ; Champaign, September 20 (Hart, I.U.) ; Algonquin, September 4 (I.U.); Urbana, August 25 (Hart, I.U.); Palos Park, Cook County, Edgebrook, Glen View, Willow Springs, July 24 to September 19 (Gerhard, Wolcott, and Liljeblad); Kankakee, August 18 (Wolcott).

Indiana: Millers, May 14. (Liljeblad).

Iowa: Nichols, September 26 (Stoner).

Kansas: Wallace County (Snow, U.S.N.M.) ; Topeka (Ashmead, U.S.N.M.) ; Doniphan County, August 22 (Brown and Guentert, K.U.) ; Sedgwick County (Warren).

Manitoba: Aweme, July 29 to August 24 (Criddle).

Michigan: Washtenaw County, October 6 (Hatch).

Nebraska: Malcolm, June 20 (Oertell) ; Lincoln (Soltau, U.S.N.M.).

New Jersey: Arlington, August 22 (A.M.N.H.).

North Dakota: Turtle Mountains, August 6 (Hubbell, U.M.) ; Devils I sake, August 12 (Hubbell, U.M.).

\section{Mordellistena sericans Fall}

Mordellistena sericans Fall, 1907, p. 256, New Mexico.

\section{DEsCRIPTION.-}

Hind tibiae with three short moderately oblique ridges, the upper one sometimes smaller and a rudimentary fourth one present in some specimens. First joint of hind tarsi with four ridges, the upper one at times feeble; second joint with two ridges.

Slender, black, rather densely clothed with grayish silky pubescence; base of antennae and front and middle legs more or less pale. Terminal joint of maxillary palpi about twice as long as wide; fourth antennal joint slightly shorter and narrower than the fifth. Length $3-3 \frac{1}{2} \mathrm{~mm}$.

New Mexico (Gallup, Highrolls, Elba); California (Pomona). An apparently common species in the southwest, specimeris of which bear the name unicolor in some collections. The latter is a stouter species with rather less silky pubescence, abdomen pale at apex, and the third tarsal joint with two ridges. (Fall) 
Remarks.-I have not examined the type of this species. A specimen of this species, however, was kindly presented to me by Fall, collected at Mesilla, New Mexico, July 31, and from this the following observations were made.

Posterior tibiae with two rather well-marked ridges and rudiment of third ridge, subapical not included; first segment of posterior tarsi with three ridges and rudiment of fourth; second with two ridges.

Slender; entirely black, except four basal segments of antennae and anterior and middle legs, which are more or less testaceous; surface entirely covered with fine, very dense, silky, silvery gray pubescence, which, in certain lights, has a greenish reflection; head minutely aciculate and punctured; eyes finely granulated and with fine hairs; antennae short, subfiliform, reaching nearly to base of thorax; third and fourth segments about equal in length, each very little shorter than fifth; sixth to tenth each about equal in length to fourth; last segment of maxillary palpi elongate, somewhat securiform.

Pronotum one-third broader than long; surface finely punctured; basal angles obtuse; basal lobe broadly rounded at middle in front of scutellum.

Elytra finely reticulate and finely punctured; apex rounded; anal style rather short, pointed.

Length: to apices of elytra, $3.26 \mathrm{~mm}$; to tip of anal style, $3.75 \mathrm{~mm}$.

This species is readily recognized, after the ridges have been examined, by its black color and dense grayish pubescence. As far as known it is found only in the South and Southwest.

Previous Records.-New Mexico and California (Fall).

Material exAmined.-Colorado: La Veta (Hubbard and Schwarz, U.S.N.M.) ; Caddoa (Snow, K.U.).

Florida: Jacksonville (U.S.N.M.).

Kansas: Hodgeman County, July 17 (K.U.) ; Douglas County, August (Tucker, K.U.) ; Rawlins County (Williams, K.U.).

North Carolina: Swannanoa Valley, May 21 (A.M.N.H.).

Texas: Columbus, July 9 (Hubbard and Schwarz, U.S.N.M.) ; Brownsville, June 19 (Townsend, U.S.N.M.), June 14 (McMillan and Marsh, U.S.N.M.) ; San Diego, June 24 (Schwarz, U.S.N.M.) ; Sharpsburg, May 10 (Schwarz, U.S.N.M.).

\section{Mordellistena leporina Leconte}

(Pl. VI, Fig. 2)

Mordellistena leporina Leconte, 1862, p. 51, middle and western states.

Description.-Posterior tibiae with three oblique, parallel ridges, and rudiment of fourth in some specimens, subapical not included; first segment of posterior tarsi with four, second with two ridges. 
Oblong, ovate; color of head and thorax fusco-ferruginous; antennae with three basal segments fusco-ferruginous, remainder fuscous; palpi fulvous; pubescence on head yellowish gray, on thorax black, except a few scattered hairs at apex, and a basal line yellowish gray; elytra fuscous, or somewhat brownish in some specimens, with humeral angle fulvous; a sutural line extended around base to humeri, where it is curved, running obliquely downward to near suture one-fourth from base; this humeral line ends onefourth flom apex, where it is connected with a transverse band that reaches to lateral margin; an interrupted band a little below middle, sometimes in form of quadrate spots, not reaching suture or lateral margin, with yellowish gray pubescence, sometimes more silvery in certain lights; anal style nearly black except extreme tip, which is pale; underside testaceous, sides of abdominal segments and apical half of last segment, fuscous.

Head moderate in size, very minutely or not at all punctured; eyes finely granulated and sparsely covered with fine hairs; antennae long, reaching nearly to middle of elytra, male with third antennal segment small, triangular; fourth segment nearly as long as first three combined; fifth to tenth about equal in length, each a little shorter than fourth; eleventh oval; female with fourth segment much narrower and shorter than in male; last segment of maxillary palpi scalene triangular, somewhat rounded on inner angle.

Pronotum broader than long, seen from above evenly rounded to apex, finely punctured; base broadly rounded at middle in front of scutellum; scutellum triangular, rounded at apex.

Elytra rather broad, with fine, granulated punctures; underside finely punctured; anal style long and slender.

Length : to apices of elytra, $3.75 \mathrm{~mm}$; to tip of anal style, $5 \mathrm{~mm}$.

REvaRKs.-This rather oddly marked species does not resemble any other North American Mordellistena, differing mainly in the color pattern and in the segments of the antennae, of which the fourth segment in the male is nearly as long as the first three combined. It was placed in synonymy under M. pubescens by J. B. Smith (1882:97), but in reality it is a valid species. Three specimens have been examined by me which agree exactly with Leconte's description and differ entirely from $M$. pubescens in color, markings, antennae, and palpi. Both pubescens and hebraica have the apex of the elytra with cinereous pubescence, but in this species the markings are subapical, not reaching the tip. The supposed type or first specimen in the Leconte collection, in the Museum of Comparative Zoology, has been examined by me; it agrees with the above description, although the markings on the type are not very distinct. It is apparently very rare.

Previous ReCords.-Central and western states (Leconte).

Material examined.-Maryland: Plummers Island, June 28 (Knab, I.S.N.M.), June 28 to August 11 (Schwarz and Barber, U.S.N.M.). 
North Carolina: Asheville, May 6 (Harnach).

Tennessee: Grassy Cove, Cumberland County, July 10 (Hubbell).

Virginia : Fredericksburg, July 22, 23 (Richardson, U.S.N.M.).

\section{Mordellistena schauppi Smith}

Mordellistena schauppi Smith, 1882, pp. 88, 96, New York.

Description.-Posterior tibiae with three short, oblique, parallel ridges, the subapical one not included; first segment of posterior tarsi with four and second with two ridges.

"Ferruginous; elytra black, with a small, indistinct humeral spot ferruginous; abdomen blackish, anterior margin of ventral segments rufous; legs pale. $3 \mathrm{~mm}$; N New York"' (Smith).

Remarks.-This species may be the same as the male of Mordellistena pulchra Liljeblad, wrongly described. The elongated basal spot at the middle of the elytra may have been taken by Smith for a humeral spot. The type, however, has not been located, and, therefore, I do not wish to place pulchra in synonymy. A specimen identified as schauppi has been located in the United States National Museum, but this cannot be the type since it is labeled New Jersey instead of New York. The original citation of type locality can scarcely be a typographical error, since New York is given also in Smith's note on page 96.

\section{Mordellistena vera Liljeblad}

(PI. VI, Fig. 11)

Mordellistena vera Liljeblad, 1917, p. 11, St. Louis, Missouri.

Description.-Posterior tibiae with three parallel, slightly oblique ridges and rudiment of fourth, subapical not included; first segment of posterior tarsi with four, second with two, and third with two small ridges.

Cuneate; black, covered with silky, brownish or reddish brown pubescence, less dense on head and thorax; elytral suture very dense, forming a narrow sutural line; antennae, mouth parts, and legs rather reddish brown; black beneath, with testaceous pubescence; abdominal segments reddish brown at apex.

Head minutely punctured; eyes coarsely granulated and with sparse hairs; antennae very long, subfiliform, reaching nearly to middle of elytra when head is recumbent; third and fourth segments short, subequal in length; fifth nearly as long as second, third, and fourth combined; sixth to tenth subequal in length, each very little shorter than fifth; eleventh as long as tenth, elongate oval, blunt at tip; last segment of the maxillary palpi scalene, rather elongate, longer and narrower in female.

Pronotum finely punctured, one-fifth broader than long, very little 
broader than elytra at base; basal lobe at middle, in front of scutellum, broad, nearly truncate; scutellum triangular.

Elytra gradually narrowing to rounded tip; margin set with short spinules; surface reticulate and with fine punctures; anal style longer in male than in female.

Length : to apices of elytra, $4 \mathrm{~mm}$; t to tip of anal style, $5.5 \mathrm{~mm}$.

REMarks.-This species is readily recognized by its color, which on the whole upper surface is black, but the dense reddish brown pubescence on the elytra makes the insect appear as bicolored; the antennae are unusually long, and each of the fifth to tenth segments is longer than the third and fourth segments combined. The ridges vary a little on the tibiae and the first segment of the tarsi. The beetle is rather rare. The type is in the Museum of Zoology, University of Michigan (Liljeblad coll.).

Previous Records.-St. Louis, Missouri; Paw Paw Lake, Michigan; and Evanston, Illinois (Liljeblad).

Material EXAMiNeD.-District of Columbia: no locality (U.S.N.M.).

Illinois: Urbana, July 23 (McElfreshm, I.U.) ; Palos Park, July 18 (Psota).

Maryland : Plummers Island, July 7 (McAtee, U.S.N.M.).

Massachusetts : Framingham, July 17 (Frost).

Michigan: Ann Arbor, July 6 (Hubbell).

New Jersey: Highlands, July 22 (A.M.N.H.) ; Phillipsburg, July 19 (J. W. Green).

New York : Flatbush, July 2 (Zabriskie, A.M.N.H.).

Pennsylvania: Point Pleasant, July 26 (J. W. Green); Natrona and Industry (Trimble); Jeannette, July (Knull); Marietta, July 12 (Gayton).

\section{Mordellistena lodingi, new species}

Type.--From Mobile, Alabama. Collected on May 2, 1916, by H. P. Loding, in whose honor it is named; in the Museum of Zoology, University of Michigan (Liljeblad coll.).

Description.-Posterior tibiae with three slightly oblique ridges, subapical not included; first segment of posterior tarsus with four slightly oblique ridges, upper a little less strongly indicated; second and third segments with two oblique ridges. All ridges well indicated on the ferruginous legs.

Cuneate; head nearly black, a little paler near mouthparts; antennae brown; maxillary palpi nearly black; eyes black; prothorax yellowish, with large, somewhat quadrate black spot and a narrow, half circle, black mark near head; scutellum fuscous yellow; elytra seemingly dark ferruginous with the suture narrowly black, a dark dash near scutellum, side margin darker and whole surface iridescent; anal style black at middle, ferruginous 
at base, apex fulvous; undersurface black, except lower half of metasternum and third and fourth abdominal segments, which are ferruginous; anterior and middle legs brown; posterior legs ferruginous.

Head rather large, surface finely and densely punctured and with short grayish pubescence; eyes elongate oval, finely granulate, hairy; antennae short, filiform, reaching to base of thorax, first three segments narrow, subequal in length, fourth segment one-third longer than third and one-fourth broader at apex, fifth to tenth segments subequal in length to fourth, each very slightly serrate, eleventh a little longer than tenth, pointed; terminal segment of maxillary palpi elongate club-shaped, nearly twice as broad at apex, which is blunt or nearly subtruncate, three times as long as preceding segment.

Prothorax one-fifth broader than long, slightly broader at middle than elytra at base; basal lobe at middle broadly rounded in front of scutellum; surface minutely aciculate and slightly reticulate with minute punctures and fine sericeous pubescence; scutellum triangular, rounded at tip.

Elytra nearly three times longer than broadest part near base, evenly tapering to apex, each elytron separately rounded; surface reticulate and finely punctured and with brownish pubescence; anal style one-third as long as elytra, tapering to a sharp point; posterior femora very little longer than first segment of tarsus.

Length : to apices of elytra, $4 \mathrm{~mm}$; t to tip of anal style, $5 \mathrm{~mm}$.

Remarks.- This insect does not resemble any of the described species in Mordellistena except in its general shape. It was sent to me labeled Mordellistena singularis Smith and belongs in the same section as that species, but the latter is described as being "well marked by the uniform ferruginous color and the deep black elytra." The specimen at hand is a male, and it may be possible that Smith's type of singularis from Georgia is the female of this species, but the type has not been located by me. The difference in color should, however, be sufficient to separate the two.

\section{Mordellistena aequalis Smith}

Mordellistena aequalis Smith, 1882, pp. 88, 96, Illinois; 1883, p. 4. Blatchley, 1910, p. 132.

\section{DESCRIPTION.-}

Hind tibiae with three short, oblique, parallel ridges. First joint of hind tarsi with four, second with three oblique ridges.

Narrow, linear; entirely black. $5 \mathrm{~mm}$.; North Illinois.

Peculiar by the combination of ridges on tibia and tarsi; resembles several other species in the uniform black color. (Smith)

REMarks.-I have not been able to locate the type of this species. Several specimens seen agree with the above description both in color and ridges, 
but it is very hazardous to attempt to verify these black forms by ridges alone before the type has been examined for the characters of palpi and antennae. The type was recorded from Illinois, and a second specimen from California was seen by Smith. From this it appears that the species has a very wide range.

\section{Mordellistena conformis Smith}

Mordellistena conformis Smith, 1883, p. 4, Texas.

\section{Description.-}

Posterior tibiae with three, first joint of posterior tarsi with four, second with three oblique ridges.

Body and elytra black, head and thorax rufous. $6 \mathrm{~mm}$. Hab. Texas.

This adds another to those species in which the head and thorax are wholly or partly red or yellow and the elytra and body are black. The tibial and tarsal ridges are exactly as in $M$. aequalis, and it is possible though not probable that at some future time this will be accounted only a variety of the preceding (aequalis). As species go now this is entitled to rank as such. Two specimens: numbered 9 and 10. (Smith)

REMarks.-This species is undoubtedly very closely allied to M. texana Smith and differs from it only in the ridges and by having the elytra rather heavily covered with gray pubescence. The type of this species, now in the United States National Museum, has been seen by me and agrees with the above description, except for the gray pubescence on the elytra, which Smith failed to mention. It cannot be associated with aequalis, which is entirely black. At least until the type of texana can be found and examined, this species will stand as valid.

Previous Records.-Texas (Smith).

Material examined.-Texas: Neuecest, April 28 (Marlatt, U.S.N.M.) ; New Braunfels, June 16 (Wickham).

\section{Mordellistena incommunis Liljeblad}

(Pl. VI, Fig. 5)

Mordellistena incommunis Liljeblad, 1921, p. 185, Riverside, Illinois.

Description.-Posterior tibiae with three rather well-marked, parallel, oblique ridges, subapical not included; first segment of posterior tarsi with four, second with three small ridges; upper ridge on tibiae and tarsi sometimes rudimentary.

Linear, slightly cuneiform; black, in certain light showing bluish green, iridescent luster; head and prothorax rather sparsely covered with yellowish brown pubescence; antennae black; elytra with golden yellow or sometimes silvery white pubescence along suture and on a rather broad vitta on each elytron, which extends from near humeral angle to a little beyond middle; undersurface black, with sparse yellowish brown pubescence; legs black.

Head a little narrower than prothorax, finely punctured; eyes small and hairy; antennae filiform, or very slightly serrate; third segment one-fourth 
shorter and a little narrower than the fourth; fifth longest; sixth to tenth segments nearly equal in length and width, each being very little longer than fourth; eleventh elongate-ovate, one-fourth longer than tenth; last segment of maxillary palpi more securiform than scalene triangular.

Pronotum finely punctured, as broad as long, widest one-fourth the distance from base, slightly rounded and converging to apex; basal lobe truncate at middle in front of scutellum; scutellum triangular.

Elytra very little wider than pronotum, widest at middle, and slightly tapering to apex, moderately punctured; inner edge of femora and tibiae of anterior legs with long setae in male, finely pubescent in female; anal style long and very slender, with cinereous pubescence at base.

Length : to apices of elytra, 3.5-4 mm.; to tip of anal style, 4-5 $\mathrm{mm}$.

REMARKs.- This species somewhat resembles $M$. suturella Helmuth, but differs in having the fourth to tenth antennal segments much shorter and very slightly serrate rather than elongate and parallel, in coloration it has no trace of vittae on the disk of the elytra. The type is in the Museum of Zoology, University of Michigan (Liljeblad coll.).

Previous Records.-Riverside, Illinois; Sawyer Dunes, Berrien County, Michigan, and Aweme, Canada (Liljeblad).

Material examined.-Alberta : Banff, August 11 (Bradford, A.M.N.H.).

Connecticut: Cornwall, July 22 (Frost).

Illinois: Galena, June 29 (Hart and Shiga, I.U.).

Maryland: Plummers Island, May 21 and June 2 (Schwarz and Barber, U.S.N.M.).

Michigan: Washtenaw County, July 26 (Hatch).

Montana: no locality (J. B. Smith, U.S.N.M.).

New Jersey: Hopatcong (Palm, A.M.N.H.) ; Paterson, June 27 (A.M.N.H.).

New York: Aurora, July 24 (Zabriskie, A.M.N.H.).

\section{Mordellistena husseyi, new species}

Type.-From Sand Point, Huron County, Michigan. A male collected on June 23, 1922, by R. F. Hussey, to whom the species is dedicated; in the Museum of Zoology, University of Michigan (Liljeblad coll.).

Allotype.-A female, same data as type.

PARATYPES.-Three males, same data as type.

Description.-Posterior tibiae in male with three oblique ridges, subapical not included; second ridge almost crossing outer face of tibiae; first segment of posterior tarsi with four small marginal ridges, second segment with two.

Elongate parallel in male, a little broader and more rounded in female; entirely black, except four basal segments of antennae, two basal segments 
of maxillary palpi, base of anterior femora, and hind tibial spurs, which are fusco-ferruginous; rather densely covered with sericeous, yellowish brown pubescence, more silvery gray on underside.

Head large, nearly as broad as elytra at base, minutely punctured; surface between punctures very minutely aciculate; eyes rather large, finely granulated and with short, fine hairs; antennae filiform, reaching a little below thorax, slightly broader in female; third segment in male a little shorter than fourth; third and fourth equal in female; fifth segment as long as third and fourth segments combined in male, one-third longer than fourth in female; sixth to tenth about equal in length, each one-fourth shorter than fifth and slightly decreasing in width to tenth; eleventh oval; all segments densely covered with fine hairs ; last segment of the maxillary palpi similar in both sexes, in shape nearly an isosceles triangle with apical side almost as long as outer.

Pronotum about as long as broad, at middle broader than elytra; seen from above, evenly rounded at apex; seen from side margin, nearly straight; surface rather coarsely punctured; base at middle, in front of scutellum, broadly rounded or very slightly emarginate; scutellum small, rounded at apex.

Elytra parallel to near apex in male, more rounded in female, slightly separated at apex ; surface with fine raised punctures ; underside finely punctured, more so on abdominal segments; anal style long and slender, pointed.

Length : to apices of elytra, 4-5 mm.; to tip of anal style, $5.75-6.75 \mathrm{~mm}$.

REMARKS.-This is another almost entirely black species of Mordellistena, with the second tibial ridge crossing the outer face. It is much longer and broader than $M$. nigricans Melsheimer and M. nigerrima Helmuth, which it resembles, except in size, but it may readily be distinguished from these other species by its unusually long anal style and by the characters of the antennae and the last segment of the maxillary palpi.

\section{Mordellistena fuscata (Melsheimer)}

Mordella fuscata Melsheimer, 1845, p. 313, Pennsylvania.

Mordellistena fuscata, Leconte, 1862, p. 51. J. B. Smith, 1882, pp. 89, 97. Blatchley, 1910, pp. 1324, 1325.

Description.-

Hind tibiae with four oblique ridges besides the subapical one. First joint of hind tarsi with three, second with two oblique ridges (Leconte).

Dark fuscous, golden sericeo-pubescent; anterior feet rufous. $1 \frac{1}{2} \mathrm{~L}$. long. Pennsylvania.

Mordella fusca, Melsh. Catal.

Dark brown, densely dull golden pubescent, punctulate and shagreened as in common; antennae filiform, hardly serrate, testaceous, dusky from before the middle to the tip; mouth and palpi testaceous; beneath and posterior feet blackish, glossy: two front pairs of feet dull rufous; anal style moderately elongate. (Melsheimer) 
REMARKs.-I have not located the type of this species. The specimen without locality label in Melsheimer's collection, named as Mordellistena fuscata, can hardly be the original type specimen, since it does not agree with the description in regard to color or ridges. This specimen has the head and thorax black and the elytra reddish brown; the posterior legs have two ridges on the third tarsal segment. Melsheimer did not mention any ridges in his description; they were added by Leconte in his synopsis, no doubt after he examined the type, and no ridges on the third tarsal segment were then included. Smith and Blatchley, in their synopses of the genus, did not mention anything about the color or ridges possessed by this supposed type, except that Smith said "color is uniform."

In view of the above details, supported by the fact that three well-known entomologists have failed to observe the described characters on this supposed type, I believe that the specimen now in Melsheimer's collection under the name of Mordellistena fuscata cannot be the original type.

What the real fuscata is I am unable to say, but from the description it seems probable that it resembles very closely a female of $M$. ambusta Leconte, which also has a rather strong rudimentary fourth ridge on the posterior tibiae. This belief is strengthened by the fact that fuscata in the Leconte collection is a specimen of ambusta. Until further evidence can be obtained, however, $M$. fuscata will remain for me a species of doubtful identity.

\section{Mordellistena rufescens Smith}

Mordellistena rufuscens Smith, 1882, pp. 89, 97, Nevada; 1883, p. 5.

\section{DESCRIPTION.-}

Hind tibiae with four short oblique, parallel ridges; first joint of hind tarsi with four, second with two oblique ridges.

Rufo-piceous; mouth, antennae, legs and elytra paler; pubescence finer sericeous. $6 \mathrm{~mm}$; Nevada.

The figure shows the tibial and tarsal ridges peculiar to this and the two following species (cinereo-fasciata and aethiops). The color is uniform and affords no indication to the species. One specimen only, Nevada; coll. Dr. Horn. (Smith)

REMARKs.-The type of this species has not been located. In a later paper by Smith (1883:5) appears the following note on this species: "No. 16, La. Agrees in all respects with the type in Dr. Horn's collection." If the specimen from Louisiana mentioned above, now in the United States National Museum, is exactly like the type, then this species is the same as $M$. liturata Melsheimer, for that specimen has been examined by me.

\section{Mordellistena masoni Liljeblad}

(Pl. VI, Fig. 3)

Mordellistena masoni Liljeblad, 1918, p. 157, Hemlock Falls, New Jersey. 
Description.-Posterior tibiae with four parallel, oblique ridges, subapical not incluled; first segment of posterior tarsi with four, second with two ridges.

Subcuneate; head and thorax dark reddish brown, covered with fine golden yellow pubescence; antennae, legs, and underside a little paler; elytra dark brown, with silky golden pubescence forming the following pattern : an oblique band from humeri nearly to suture, an entire marginal line widest at middle, where it forms an abbreviated band, a sutural streak, an apical blotch connected with the marginal line, and several spots between the bands.

Head minutely punctured; eyes coarsely granulated and hairy; antennae reaching to a little below thorax, fifth to tenth segments slightly serrate; third and fourth segments narrow; fifth broadest, nearly twice as broad at apex as fourth ; sixth to eleventh slightly diminishing in width; last segment of maxillary palpi scalene triangular.

Pronotum one-third broader than long; sides evenly rounded to apex; surface minutely aciculate and finely punctured; basal angles rounded; basal lobe broadly rounded at middle in front of scutellum; scutellum triangular, rounded at tip.

Elytra a little narrower at base than pronotum and tapering to near apex, which is rounded; surface minutely aciculate and finely punctured; anal style slender one-third from base.

Length: to apices of elytra, $3.75-4 \mathrm{~mm}$.; to tip of anal style, $4.75-5 \mathrm{~mm}$.

REMARKs.-This species most nearly resembles $M$. discolor and liturata, but may readily be recognized by the sutural and marginal lines, by its basal and middle bands, and by the several small spots between the bands. The bands in some specimens are a little variable. The type is in the Museum of Zoology, University of Michigan (Liljeblad coll.).

Previous Records.-Hemlock Falls, Eagle Rock, and Westville, New Jersey (Liljeblad).

Material examined.-Florida: Biscayne, April 5 (U.S.N.M.) ; Saint Lucie (U.S.N.M.) ; Monticello, May 11 (Craighead, U.S.N.M.) ; Crescent City, April 24 (Van Duzee, A.M.N.H.).

New Jersey: Highlands, July 8 (Soltau, U.S.N.M.) and same locality, July 22 (A.M.N.H.).

\section{Mordellistena aethiops Smith}

(Pl. VI, Fig. 10)

Mordellistena aethiops Smith, 1882, pp. 89, 98, Colorado; 1883, p. 5.

Description.-Posterior tibiae with four ridges and rudiment of fifth in female, subapical not included; first segment of posterior tarsi with four ridges and rudiment of fifth in female; second with two ridges. All ridges more or less indistinct and uneven in length. 
Subcuneiform, rather long and narrow; entirely black, except mouth parts, basal segments of antennae, and anterior and middle femora in male, which are ferruginous; female entirely black; pubescence brownish gray.

Head moderately large, minutely aciculate and finely punctured; eyes finely granulated, not hairy; antennae filiform, somewhat broad, reaching to base of thorax; third and fourth segments short, each a little shorter than fifth; fifth and sixth subequal in length; seventh to tenth each one-fifth shorter than sixth; last segment of maxillary palpi securiform, with inner and apical sides about equal.

Pronotum one-third broader than long, basal angles acute, basal lobe at middle, in front of scutellum, broad, somewhat truncate at middle; surface finely punctured.

Elytra at base a little narrower than pronotum, finely punctured; apex rounded; anal style long and slender.

Length : to apices of elytra, $3.25-4 \mathrm{~mm}$; t to tip of anal style, $4.25-5 \mathrm{~mm}$.

Remarks.-This species resembles $M$. aemula Leconte, but differs from that form by not having the elytra mottled. The type has not been located, but several specimens have been examined that agree with Smith's description. The form is rather rare.

Previous Records.-Colorado and Nebraska (Smith) ; La Juncta, Colorado (Wickham); and Fort Collins, Colorado (Wickham).

Material examined.-Arizona: Adamana, July 12 (Miss E. W. Mank).

Colorado: Mount Lookout, Golden, June 26 and no locality (Palm, A.M.N.H.) .

Louisiana: Opelousas (Pilate, U.S.N.M.).

\section{Mordellistena texana Smith}

Mordellistena texana Smith, 1882, pp. 89, 98, Texas.

Mordellistena insolita Liljeblad, 1917, p. 11.

Description.-Posterior tibiae with four oblique, parallel ridges, the subapical one not included; first segment of posterior tarsi with four and a rudimentary fifth in some specimens and second with three ridges. Texas.

Black, with sericeous pubescence; head, thorax and front legs ferruginous. $5 \mathrm{~mm}$.;

Another of those species having the thorax red and elytra and body black, and therefore distinguishable only by the ridges of tibia and tarsi. Two specimens, Texas; Coll. Dr. Horn and myself. (Smith)

REMarks.-I have been unable to locate the type of this species. Several specimens have been seen that no doubt belong to this species, but with only a line of description for a guide and without having seen the type, it is difficult to identify specimens with absolute certainty. It seems unquestionable, however, that texana has the thorax ferruginous without dark markings and the elytra shiny black with a little reddish brown pubescence, not at all gray 
as in conformis. It also resembles cervicalis, but this has the thorax with dark markings. $M$. insolita Liljeblad, also from Texas, was based on a specimen with two small ridges on the third tarsal segment, but these ridges were later seen to be of rudimentary character and too small to be considered true ridges, so that the species without doubt is the same as texana. Until the type of texana can be examined, the above notes must serve to identify the species.

\section{Mordellistena hoosieri Blatchley}

Mordellistena hoosieri Blatchley, 1910, pp. 1324, 1325, Kosciusko County, Indiana.

\section{DESCRIPTION.-}

Hind tibiae with only four ridges besides the subapical one. First joint of hind tarsi with five ridges; second joint with three ridges, third with none.

Color reddish brown.

More slender and paler reddish brown than fuscata, the pubescence sparser and a little longer ; antennae, front and middle legs wholly dull reddish yellow. First joint of hind tarsi with five distinct ridges. Length $3.5-4.5 \mathrm{~mm}$. Kosciusko County; rare. June 19. Described from two specimens taken by sweeping low herbage in dense woods. (Blatchley)

REMARKS.-I have not seen the type, nor any specimen that agrees with the above description. M. fuscata Melsheimer is mentioned by Blatchley as being somewhat like the above species. This, however, is also unknown to me, for the specimen under that name in Melsheimer's collection cannot be considered the type (see note under fuscata).

\section{Mordellistena suturella Helmuth}

Mordellistena suturella Helmuth, 1864, p. 105, Illinois. J. B. Smith, 1882, pp. 89, 98.

Blatchley, 1910, pp. 1325, 1326.

Description.-Posterior tibiae with four parallel, oblique ridges, upper one sometimes rudimentary, subapical not included; first segment of posterior tarsi with five and second with three ridges.

Cuneiform, female a little more robust; entirely black, except basal half of anterior femora in male, which is ferruginous, covered with fine, sericeous, cinereous pubescence on head and thorax; the elytra have a narrow sutural cinereous line ; underside (more or less) and base of anal style with cinereous pubescence.

Head moderately large, finely punctured; eyes finely granulated and hairy ; antennae filiform, somewhat narrow toward the tip ; third and fourth segments subequal in length, each one-fourth shorter than fifth; sixth to tenth subequal, each a little shorter than fifth; last segment of maxillary palpi cultriform or nearly so.

Pronotum about one-fourth broader than long, finely punctured; posterior angles slightly produced backward and pointed; basal lobe at middle, in front of scutellum, prominent, broadly rounded. 
Elytra narrower than pronotum at base; tip rounded; surface somewhat coarsely punctured; anal style long and slender.

Length : to apices of elytra, 3.5-5 mm.; to tip of anal style, $4.5-7 \mathrm{~mm}$.

REMARKs.-This species is readily recognized for it is entirely black except for the basally ferruginous anterior femora of the male and the narrow silvery white sutural line on the elytra. It somewhat resembles Mordella lunulata Helmuth, but that species has no ridges on the posterior legs and has a short humeral vitta on the elytra. The type is probably destroyed, but a neotype has been selected by me from Palos Park, Illinois, May 28, 1922. It is rather abundant near Chicago, Illinois, and appears from May to June, being taken on wild rose.

Previous RECORDs.-Illinois (Helmuth) ; Colorado and District of Columbia (Smith) ; Cincinnati, Ohio (Dury) ; Tippecanoe County, Indiana, June 21-25 (Blatchley).

Material examined.-Illinois: Palos Park, June 25 (Gerhard, Wolcott, and Liljeblad) ; Riverside, June 27 (Selinger); Elgin, May 29 (Bristol); Litchfield, Champaign, Villa Ridge, and Urbana, May 23 to June 29 (Martin and Mally, I.S.N.H.S.) ; Pesotum, June 5 (Hart, I.U.).

Indiana: Lafayette, June 21 (Wolcott).

Kansas: Onega County (Knaus) ; Linn County (Beamer, K.U.) ; Clark County, May (Snow, K.U.).

Manitoba: Aweme, June 19-July 3 (Criddle).

\section{Mordellistena gigas Liljeblad}

(Pl. VI, Fig. 4)

Mordellistena gigas Liljeblad, 1917, p. 13, Edgebrook, Illinois.

DESCRIPTION.-Posterior tibiae with four ridges, subapical not included; first segment of posterior tarsi with four ridges and rudiment of fifth; second segment with two ridges and third with one ridge.

Subcuneiform; head, thorax, four basal segments of antennae, palpi, and all legs rufous; elytra black, with humeral angle, basal margin, and suture with golden yellow pubescence; rest of elytra sprinkled with reddish brown iridescent pubescence; underside rufo-testaceous with mesosternum, hind coxal plates, and basal margin of first and second abdominal segments fuscous; anal style rufous, fuscous at apex.

Head large, shining, finely punctured, and minutely aciculate; eyes small, not reaching occiput, finely granulated, and with very fine hairs; antennae short, reaching a little below thorax, subfiliform, fourth segment shortest, one-fourth shorter than third, fifth nearly as long as third and fourth combined and nearly twice as broad near apex as fourth; sixth to tenth subequal in length, each one-fifth shorter than fifth; last segment of maxillary palpi short, securiform. 
Pronotum more coarsely punctured, one-third broader than long; basal angle rounded; basal lobe at middle, in front of scutellum, not very prominent, broad and truncate at middle; scutellum comparatively small, rather broadly triangular, rounded at tip.

Elytra nearly as broad as pronotum at base; surface with raised punctures; apex rounded; anal style short, rather blunt at tip.

Length : to apices of elytra, $6 \mathrm{~mm}$.; to tip of anal style, $6.5 \mathrm{~mm}$.

REMARKS.-This is one of the largest species of Mordellistena and is a rather handsome beetle. It may to some extent resemble $M$. fuscipennis in color, but not otherwise. Only one specimen, the type, has been found, at Edgebrook, Illinois, July 10, by me; in the Museum of Zoology, University of Michigan (Liljeblad coll.).

\section{Mordellistena fusco-atra Helmuth}

Mordellistena fusco-atra Helmuth, 1864, p. 105, Illinois. J. B. Smith, 1882, pp. 89, 98; 1883 , p. 80 .

\section{Description.-}

Hind tibiae with four ridges. First joint of hind tarsi with four, second and third each with three ridges.

Very slender, dark fuscous, four basal joints of antennae, anterior and middle feet piceous, pubescence brown sericeous. '14. (Helmuth)

REMARKS.-I have not seen any specimen that agrees with the diagnosis; the type is no doubt destroyed.

\section{Mordellistena rufiventris Helmuth}

Mordellistena rufiventris Helmuth, 1864, p. 105, Illinois. J. B. Smith, 1882, pp. 89, 98.

\section{Description.-}

Hind tibiae with four ridges; first joint of hind tarsi with five, second with three, third with two ridges.

Black, pubescence of head and thorax brownish, of elytra black, with the suture narrowly gray, abdomen rufous, varied with black. $\cdot 20$. Illinois. (Helmuth)

REMarKs.-Only two specimens have been seen by me that seem to agree with Helmuth's description; one is in the American Museum of Natural History and the other in the Carnegie Museum, and from the former the following description has been taken.

Posterior tibiae with three ridges and rudiment of fourth, subapical not included; first segment of posterior tarsi with four and rudiment of fifth ridge, second segment with three, third with two ridges.

Elongate; head and thorax black with fine, short, yellowish gray pubescence, but the black ground color is not at all concealed by the lighter pubescence; antennae and palpi ferruginous; elytra black, densely covered with reddish brown pubescence which, on the suture, is laid longitudinally 
and thereby shows a narrow sutural line; underside black with apical abdominal segment more or less rufous; anterior and middle legs rufous; posterior legs a little more fuscous.

Head rather large, minutely aciculate and finely punctured; eyes small, not quite reaching back of head, somewhat coarsely granulated and hairy; antennae filiform, reaching a little below thorax; third and fourth segments shortest, fourth a little shorter than third; fifth a little longer than third and fourth combined; sixth to tenth subequal in length, each about onefourth shorter than fifth; last segment of maxillary palpi elongate, inner side twice as long as apical edge.

Pronotum one-third broader than long, broadly rounded to apex; hind angles subacute; basal lobe broadly rounded in front of scutellum; surface minutely aciculate and with fine punctures.

Elytra at base a little narrower than pronotum; sides nearly parallel to near tip; surface with fine raised punctures; underside very finely punctured; anal style moderately long and slender.

Length: to apices of elytra, $4 \mathrm{~mm}$.; to tip of anal style, $5.5 \mathrm{~mm}$.; width, $1.75 \mathrm{~mm}$.

This species was placed as a variety of $M$. suturella Helmuth (Junk, 1915 : 44), but judging by Helmuth's description as well as by the specimens examined, I cannot associate this species with suturella, which does not have any ridges on the third tarsal segments and has the abdomen black.

Previous Records.-Illinois (Helmuth).

Material EXAmined.-New Jersey: Highlands, July 22 (A.M.N.H.).

\section{Mordellistena angusta Leconte}

Mordellistena angusta Leconte, 1862, p. 51, Georgia. J. B. Smith, 1882, pp. 89, 98.

\section{DESCRIPTION.-}

Hind tibiae with four oblique ridges besides the subapical one. First joint of hind tarsi with five, second with four and third with three small oblique ridges.

Very slender, entirely black, pubescence fine and dark. 23. Georgia. (Leconte)

Remarks.-This species is entirely unknown to me. Leconte's supposed type, in the Museum of Comparative Zoology, which appears to be a female, has only two ridges on the third tarsal segment.

\section{Mordellistena attenuata (Say)}

(Pl. VI, Fig. 6)

Mordella attenuata Say, 1826, p. 243, Rocky Mountains; 1859, p. 308.

Mordellistena attenuata Leconte, 1862, p. 51. J. B. Smith, 1882, pp. 90, 98.

Mordellistena vittigera Leconte, 1862, p. 51.

DesCRIPTION.-Posterior tibiae with five ridges, subapical not included; first segment of posterior tarsi with four ridges, second with one ridge; all ridges very small and usually uneven. 
Rather broad, nearly parallel or very slightly tapering to near apex; head except eyes rufous; antennae with basal segments rufous, otherwise fuscous or dark reddish brown; thorax in male rufous or rufo-testaceous with a large black spot on anterior disk which, in some specimens, is extended at middle in a line to base; female entirely black, with fine yellowish brown pubescence, longer, coarser and denser at base and sides; elytra black with an oblique, humeral, rufous or rufo-testaceous vitta from base to slightly below middle; this vitta covered with fine, golden yellowish pubescence, which extends beyond vitta to near tip, where it is as broad as at base but rounded in form; in this manner the pubescence forms a vitta nearly the full length of elytra, leaving a rather broad sutural streak broadest at base, a marginal streak broadest at middle, and the tip black; underside black, covered with silky golden pubescence; anterior legs reddish brown; posterior legs nearly black in male, fuscous in female.

Head large, about one-third narrower than thorax at base, very finely punctured; eyes small, hairy, rather coarsely granulated; antennae filiform in male, very slightly serrate in female, with second to fourth segments about equal in length; third and fourth more triangular in shape; fifth as long as third and fourth combined but a little broader at apex; sixth a little shorter than fifth; seventh to tenth about equal in length, each a little shorter than sixth; eleventh one-fourth longer than tenth, bluntly rounded at tip ; last segment of maxillary palpi scalene triangular.

Pronotum about one-fourth broader than long, very slightly curved at sides, finely punctured; basal lobe broadly rounded at middle in front of scutellum; scutellum triangular, broadly rounded at apex.

Elytra a little narrower than pronotum, finely reticulate and punctured; apex rounded; anal style moderately long and very pointed.

Length : to apices of elytra, $4 \mathrm{~mm}$.; to tip of anal style, $5.25 \mathrm{~mm}$.

REMarKs.-This is one of our species that has been placed in many collections under two names: attenuata for the male and vittigera for the female. It is a rather pretty insect and may very readily be recognized by the peculiar vitta on the black elytra, which is rufous on the chitinized basal part, broad at base, and very pointed a little below the middle; the rest of the entire vitta is formed by the pubescence and reaches nearly to the tip of the elytra. The only difference in the sexes is in the color of the thorax and posterior legs, and in the antennae, which are slightly serrate in the female, not at all so in the male. The ridges are very short and uneven and therefore difficult to distinguish.

Previous Records.-Rocky Mountains (Say); Pennsylvania (Leconte); New York (Smith); southwestern Pennsylvania (Hamilton).

Material examined.-Alabama: Langdale, Chambers County (H. H. Smith, U.S.N.M.). 
Kentucky : no locality (Dury).

North Carolina: Asheville, May 6 (Harnach).

Virginia: Mount Vernon, June 17 (Chamberlain).

\section{Mordellistena aemula Leconte}

(Pl. VI, Fig. 9)

Mordellistena aemula Leconte, 1859, p. 16, Platte River. J. B. Smith, 1882, pp. 90, 98.

DESCRIPTION.-Posterior tibiae with five small ridges, apical longest, subapical not included; first segment of posterior tarsi with five and second with two ridges.

Linear; entirely black above and beneath, covered with rather dense, silvery gray pubescence which is more or less mottled on elytra.

Head rather large, minutely aciculate and finely punctured; eyes small, finely granulated and hairy; antennae short, subfiliform, reaching to about base of thorax; fourth segment a little longer than third; fifth and sixth subequal in length, each one-fifth longer than fourth; seventh to tenth equal in length, one-fourth shorter than sixth; last segment of maxillary palpi scalene triangular, inner side a little longer than apical edge.

Pronotum about one-fourth broader than long in male and one-third in female; surface minutely aciculate and punctured; basal angles obtuse; basal lobe at middle, in front of scutellum, broad, rounded.

Elytra a little narrower than pronotum at base; surface firmly punctured; sides parallel to near apex; anal style long and slender.

Length: to apices of elytra, 3-4 mm.; to tip of anal style, 4-5 mm.

Remarks.-This species has often been taken to be the same as $M$. aethiops, but it can readily be recognized by its more or less mottled elytra. The ground color is entirely black. To place it properly the ridges should be carefully examined, as the upper ones are very small. From specimens on hand for examination, I find that great variation prevails in the ridges. In his original description Leconte stated that there are six or seven ridges on the tibiae on the superexternal margin, five on the first segment of the tarsi, and two on the second segment, but in his synopsis he noted only five or six very small ridges on the tibiae. Leconte's supposed type in the $\mathrm{Mu}$ seum of Comparative Zoology has been examined and found to agree with the above description. On the basis of the specimens examined, not more than four of the tibial ridges can be said to be real; the others are more or less rudimentary, with one or two spinules on the very margin. In two examples there are really only three ridges on the tibiae. The tarsal segments are as stated, although small, and in two or three specimens a rudimentary third ridge is to be seen on the second tarsal segment.

The pubescence is somewhat variable, ranging from an uneven mottling to more or less pronounced spots. The antennal segments also differ a little 
in width, and some are more triangularly shaped, whereas others have the sides a little more parallel; all the segments are shorter in the female. The species is rather rare in collections.

Previous Records.-Platte River (Leconte); Kansas (Smith); West Cliff, Pueblo, Platte River, La Veta, Manitau, Garland, Colorado (Wickham); Davenport, Iowa (Putnam record).

Material examined.-Arizona: Adamana, July 12 (Miss E. W. Mank).

California: Los Angeles County (Coquillet, U.S.N.M.).

Colorado: Denver, July 11 (Frost).

Kansas: Gove, Logan, and Rawlins counties (Williams, K.U.) ; Douglas County, August 1 (Hoffmann, K.U.); Bourbon and Sumner counties (Beamer, K.U.) ; Reno County, August 13, and Hodgeman County, July 17 (K.U.).

Nebraska: Cambridge, June 24, July 2 (A.P.M., Frost coll.) ; Sand Hills, July (U.S.N.M.).

New Mexico: Las Vegas (I.U.).

North Dakota: Stump Lake, Nelson County, July 24 (Hubbell).

\section{KEY TO GENERA OF ANASPINI}

Anterior and middle tarsi with fourth segment about equal to third 2

Anterior and middle tarsi with fourth segment very small ................................................................ 3

2. Antennae long, scarcely thickened externally, with third and fourth segments about equal in length

Antennae shorter, last segments broader; segments four to six short

(p. 196) Pentaria

Antennae very short; the elytra strigate only at base, species very small

(p. 202) Naucles

Head small, compressed, the neck not visible unless the head is extended; labial palpi crescent-shaped; elytra entirely transversely strigate, species very small

(p. 206) Sphingocephalus

3. Antennae gradually thickened externally, third abdominal segment in the male with movable appendages (p. 207) Anaspis

Third abdominal segment in the male without movable appendages

4. Epipleura long, distinctly visible to the third abdominal segment

\section{4}

5. First segment of posterior tarsi distinctly shorter than the tibiae (p. 219) Silaria

First segment of posterior tarsi at least as long as the tibiae, abdominal segments at middle with long setae (p. 220) Larisia

6. Posterior tibiae shorter than the first and second tarsal segments combined

(p. 222) Nassipa

\section{DICLIDIA LECONTE}

Diclidia Leconte, 1862, p. 43. J. B. Smith, 1882, pp. 74, 75. Champion, 1891, p. 250.

DESCRIPTION.-Scutellum rounded triangular; last dorsal segment not prolonged, sixth ventral visible; posterior tibiae slender, without ridges; fourth segment of anterior and middle tarsi emarginate, not smaller than 
the third; claws dilated at base; posterior femora small; mesosternum compressed, elevated; eyes coarsely granulated, with a small emargination; antennae long and slender, slightly thickened externally, not serrate; third and fourth segments each nearly equal to first and second combined; fifth and sixth a little shorter; the sculpture consists of fine transverse lines.

In the male, if the genitalia are extruded, are two long appendages, one on each side of the aedeagus, which are variable in form.

REMarks.- This genus differs from Anthobates in the form of the antennae, which are long and slender, very slightly thickened externally, in the form of the mesosternum and in the sexual characters.

In the present genus nine species, so far as known, occur in North America. Four, sexmaculata, obscura, spinea, and sordida, are here recorded for the first time. The type, by monotypy, is Diclidia laetula Leconte.

\section{KEY TO SPECIES}

Color more or less banded 2

Color uniform or nearly so

2. Elytra yellow with scutellar cloud and two bands black, apex pale; male appendages long, gradually increasing in width to apex, which is oblique and slightly sinuate near the tip ; Pl. VI, Fig. 16 (p. 188) lactula

Elytra testaceous, basal cloud at middle and two bands black, apex pale; male appendages long and pointed; Pl. VI, Fig. 17 .............................. (p. 189) sexmaculata

Elytra with scutellar cloud, median band, and apex black (female); Pl. VI, Fig. 18 (p. 190) propinqua

Elytra with scutellar cloud and apical half fuscous; male with appendages long, broad, flattened, and emarginate at apex; Pl. VI, Fig. 15

3. Entirely testaceous or flavo-testaceous; male appendages gradually increasing in width to an obliquely truncate apex; Pl. VI, Fig. 14 ............................... (p. 192) greeni

Flavo-testaceous, scutellar cloud, suture to middle and apical half fuscous; lower margin of posterior femora with a short spine; male appendages gradually broadened and flattened at tip (p. 193) spinea

Entirely fulvous; male appendages narrow, pointed at apex (p. 194) gilva

Dark reddish brown; male appendages long, dilated and rounded at apex

(p. 194) inyocnsis

Entirely fusco-testaceous or fusco-rufous, legs paler (p. 195) sordida

\section{Diclidia laetula (Leconte)}

(Pl. VI, Fig. 16)

Anaspis laetula Leconte, 1858, p. 76, Texas.

Diclidia lactula (Leconte), 1862, p. 43. Packard, 1883, p. 168. J. B. Smith, 1882, p. 75.

DESCRIPTION.-Elongate, somewhat oval; yellow or reddish yellow, with a black or dark cloud below scutellum; a black abbreviated band at middle not reaching suture and a broader black band near tip.

Head moderately large; antennae long and slender, slightly thickened externally, not serrate; third and fourth segments each nearly equal in 
length to first and second combined; fifth and sixth a little shorter; last segment of maxillary palpi elongate, cultriform; eyes coarsely granulated with a small emargination.

Pronotum one-third broader than long, scarcely narrower than elytra at base; sides evenly rounded to apex; surface finely, transversely strigate and punctured; hind angles obtuse; scutellum rounded, triangular at tip.

Elytra a little tapering to rounded apex; surface finely, transversely strigate; last dorsal segment not prolonged; sixth ventral visible; posterior tibiae slender, without ridges; fourth segment of anterior and middle tarsi emarginate, not smaller than third ; claws dilated at base.; mesosternum compressed, much elevated; fifth ventral segment, in male, broadly emarginate, and at each side of the aedeagus, if extruded, is a long, strongly dilated appendage; this appendage is convex on upper side and somewhat concave beneath; at tip it is oblique, slightly curved inward and sparsely covered with hairs.

Length : $3 \mathrm{~mm}$.

REMARKs.-This species is rare in collections. It can be distinguished readily by the markings of the elytra and by the male appendages. The black marking's on the elytra are variable; the scutellar and middle bands are sometimes absent; the middle band varies in size, being sometimes abbreviated (as in the drawing of the type) or entirely crossing the elytra in some specimens. The spot near the tip is, however, always present. The females are usually more strongly marked with black.

I have examined comparatively few specimens besides the type and other specimens in the Leconte collection, in the Museum of Comparative Zoology. Of these No. 1 is the type, bearing a red label (Gulf states); No. 2, Texas; No. 3, no label; and No. 4, Manitou, Colorado.

Previous records.-Texas (Leconte); Ohio (Smith); Manitou, Colorado (Packard).

Material examined.-California: Santa Monica, May 1 (I.U.).

Colorado: Pikes Peak (Hubbard and Schwarz) ; Buena Vista (Hubbard and Schwarz); Manitou, April 3 (I.U.).

Texas : Newecest, April 26-29 (Marlatt) ; Brownsville (Townsend) ; San Diego, May 1-31 (Schwarz).

\section{Diclidia sexmaculata, new species}

(Pl. VI, Fig. 17)

TrPe.-From Chiricahua Mountains, Arizona. A male, collected June 8-11 by Hubbard and Schwarz; in the collection of the United States National Museum.

Allotype.-A female, same data as type; in the collection of the United States National Museum. 
PARATyPes.-Fifty-two specimens, same data as type; in the collections of United States National Museum and Museum of Zoology, University of Michigan (Liljeblad coll.).

DESCRIPTION.-Oblong oval, female usually much stouter than male; head testaceous, antennae and palpi a little paler; eyes black; thorax fusco-testaceous, with a darker cloud at middle in most specimens; elytra with middle of base, suture, a broad band at middle, and another band near apex, black, leaving a curved band near base, one below middle, and a narrow apex testaceous; female with dark basal markings more extended; underside with abdomen more or less black; legs testaceous; upper surface with very fine grayish pubescence.

Head one-half width of pronotum, surface minutely strigate; eyes rather coarsely granulated, not hairy or only with a few setae near hind margin, and with a small emargination behind antennae; antennae long, with four segments reaching below thorax; third and fourth segments about equal in length, each nearly as long as first and second combined; fifth one-third shorter than fourth; sixth a little shorter than fifth, slightly dilated at apex; seventh to tenth about equal in length, each as long as fifth and dilated at apex; eleventh elongate, nearly twice as long as tenth, pointed; last segment of maxillary palpi triangular, with outer side one-third longer than inner.

Pronotum fully one-third broader than long, broadest at base and evenly narrowed to apex; basal angles subacute; surface very finely strigate and minutely punctured.

Elytra broadest a little before middle; surface transversely strigate and finely punctured.

Abdomen with sixth ventral segment visible. Male with two long, narrow, somewhat pointed appendages, one each side of the aedeagus; these can be seen only when the genitalia are extruded.

Length : $2.5-3.5 \mathrm{~mm}$.

REMARKS.-The female of this species resembles $D$. propinqua Liljeblad, which was described from two female specimens collected at Jemez Mountains, New Mexico, but as no males of that species have been examined, it cannot be ascertained if the present species is the same. In color pattern it resembles to some extent $D$. laetula Leconte, but that species is paler in color and has the male appendages broadly dilated at apex.

This species is somewhat variable in the markings of the elytra; some specimens have the basal spot just visible and others have both the basal and middle bands partly obliterated.

\section{Diclidia propinqua Liljeblad}

(Pl. VI, Fig. 18)

Diclidia propinqua Liljeblad, 1918, p. 153, Jemez Mountains, Arizona. 
Description.-Moderately elongate, with very fine, silvery pubescence; head behind antennae dark reddish brown; mouth parts, antennae, and thorax testaceous; elytra with a scutellar cloud, suture to middle, a broad median band, and apex black or very dark brown; abdomen nearly black; legs testaceous.

Head small, about one-half size of thorax; surface circularly strigate; antennae with first and second segments equal in length, each one-third shorter than third; third and fourth equal in length, each nearly as long as first and second combined; fifth one-third shorter than fourth; sixth to tenth each a little shorter than fifth and converging to apex; eleventh elongate, pointed at tip ; last segment of maxillary palpi somewhat scalene triangular; eyes oblong, coarsely granulated, not hairy, and with a small emargination behind antennae.

Pronotum one-fourth broader than long; sides rounded and rapidly converging from middle to apex; surface finely, transversely strigate; mesosternum very little compressed and elevated.

Elytra at base slightly broader than pronotum, broadest at middle; apex abruptly curved; surface finely, transversely strigate and punctured; sixth ventral segment not visible unless the genitalia are extruded.

Length : $3.75 \mathrm{~mm}$.

REMARKS.-This species somewhat resembles $D$. laetula Leconte and sexmaculata Liljeblad, but can readily be distinguished from them by the color of the elytra, which are pale at their apices in these species and black in propinqua. Only the type, a female, has been recorded by me from the Jemez Mountains, New Mexico, collected by Woodgate; in the Museum of Zoology, University of Michigan (Liljeblad coll.).

\section{Diclidia obscura, new species}

(Pl. VI, Fig. 15)

Trpe-From Baboquivari Mountains, Arizona. A male, collected by H. C. Fall in the Fall collection in the Museum of Comparative Zoology.

Allorype.-A female, Sabino Canyon, Tucson, Arizona, collected by J. F. Tucker ; in the Museum of Zoology, University of Michigan (Liljeblad coll.).

Paratrypes.--One, Sabino Canyon, Tucson, Arizona, collected by J. F. Tucker; three, Oracle, Arizona, June 10, collected by Hubbard and Schwarz; two, Fort Grant, Pinaleno Mountains, Arizona, July 15, Cornell University; two from Kits Peak, Rincon, Baboquivari Mountains, Arizona, August 1-9, American Museum of Natural History; paratypes in the collections of C. A. Frost, United States National Museum, American Museum of Natural History, and Cornell University.

Description.-Oblong oval; upper surface entirely covered with fine, 
silky, light yellowish brown pubescence; head fusco-testaceous; palpi testaceous; antennae with seventh to eleventh segments fuscous; eyes black; thorax testaceous; elytra testaceous with a scutellar cloud, suture to middle, and apical half fuscous; underside testaceous, abdomen a little darker in male.

Head one-half width of thorax, finely, circularly strigate; eyes coarsely granulated, with a rather deep emargination near antennae; antennae with third and fourth segments about equal in length; fifth one-third shorter than fourth; sixth a little shorter than fifth; seventh to the tenth equal in length, gradually increasing in width; eleventh elongate, twice as long as tenth, pointed at tip ; last segment of maxillary palpi cultriform.

Pronotum one-third broader than long, slightly broader than elytra at base, finely transversely strigate; sides rounded and converging to apex; posterior angles acute.

Elytra finely, transversely strigate, broadest at middle and broadly rounded at apex; male with two long, rather broad, flattened appendages, emarginate at apex, one each side of the aedeagus.

Length : $3 \mathrm{~mm}$.

REMarKs.-This species somewhat resembles $D$. greeni Liljeblad, but differs from that species by having the outer segments of the antennae nearly black, the apical half of the elytra fuscous, and the male appendages deeply emarginate at tip, whereas in $D$. greeni the color is entirely pale and the appendages are not at all emarginate.

\section{Diclidia greeni Liljeblad}

(Pl. VI, Fig. 14)

Diclidia greeni Liljeblad, 1918, p. 153, Chisos Mountains, Texas.

Description.-Moderately elongate, a little broader in female; almost entirely pale testaceous or flavo-testaceous; head a little darker; eyes nearly black; some specimens with an indication of a dark transverse cloud near apex of elytra; surface densely and very finely pubescent.

Head small, scarcely one-half width of thorax, surface finely, circularly strigate; antennae long, with four apical segments reaching below base of thorax; third and fourth segments equal in length, each as long as first and second combined; fifth one-third shorter than fourth; sixth shorter than seventh; seventh to tenth nearly equal in length and a little broader than sixth; eleventh twice as long as tenth.

Pronotum about twice as broad as long, sides rounded and rapidly converging from a little before base; basal angles acute; surface finely, transversely strigate; mesosternum very much compressed and elevated.

Elytra nearly as broad as pronotum, broadest at middle, slightly rounded to near apex, which is rather broadly rounded; surface like pronotum. Male with two long, flattened appendages, one each side of aedeagus; these ap- 
pendages widened distally and obliquely truncate at apex, not visible unless genitalia are extruded.

Length : 3-3.75 $\mathrm{mm}$.

Remarks.-This species differs notably from $D$. laetula in the nearly uniform pale color and in the obliquely truncate male appendages. The type is in the Museum of Zoology, University of Michigan (Liljeblad coll.).

Previous Records.-Davis and Chisos Mountains, Texas (Liljeblad).

Material examined.-Arizona, Baboquivari Mountains (Snow, K.U.).

Texas: Dallas, June 26 (Schwarz and Pratt) and San Antonio (Soltau coll.).

\section{Diclidia spinea, new species}

Type.-From Huachuca Mountains, Arizona. A male, collected on July 11-30 by H. W. Wenzel; in the collection of Ohio State University.

Alcorype.-A female, same data as type.

Paranypes.--Three males and two females, same data as type; in the Museum of Zoology, University of Michigan (Liljeblad coll.).

Description.-Oblong-oval; head and thorax and palpi flavo-testaceous, antennae with six basal segments flavo-testaceous, apical segments fuscous; eyes black; elytra flavo-testaceous with a scutellar cloud, suture to middle and apical half fuscous or nearly black toward apex; underside in male flavo-testaceous; abdomen fuscous, female with underside fuscous.

Head one-half width of thorax, irregularly strigate; eyes coarsely granulated and with a small emargination behind antennae; antennae long, reaching below thorax; first and second segments short; third and fourth segments each nearly as long as first and second combined; fifth one-third shorter than fourth; sixth to ninth gradually increasing in width; eighth to tenth moniliform; eleventh oval, nearly twice as long as tenth; last segment of maxillary palpi in male nearly an isosceles triangle, in the female scalene triangular.

Pronotum one-third broader than long, a little broader than elytra at base, finely transversely strigate; sides rounded, converging to apex; posterior angles obtuse.

Elytra slightly cuneiform, transversely strigate, rounded at apex, finely margined at tip; male with two long appendages, gradually broadened and flattened to apex, which is slightly oblique and with long setae, one each side of aedeagus, these not visible unless the genitalia are extruded; posterior femora on lower margin near the middle with a short obtuse spine; female like male, but without spine.

REMarks.-This species resembles $D$. obscura Liljeblad, but has the apical segments of the antennae elongate and the male appendages emarginate at tip and has no spine on the posterior femora. 


\section{Diclidia gilva Liljeblad}

Diclidia gilva Liljeblad, 1921, p. 182, Inyo Mountains, California.

Description.--Subcuneate or nearly parallel; upper surface entirely fulvous except eyes, which are black; underside of abdomen fuscous; legs fulvous.

Head comparatively large; eyes coarsely granulated and with a rather deep emargination; antennae with second segment a little shorter than first; third and fourth segments about equal in length, each about as long as first and second combined; fifth one-third shorter than fourth; sixth a little shorter and broader than fifth; seventh to tenth about equal in length but much broader than sixth; eleventh twice as long as tenth.

Pronotum about one-third broader than long, as broad as elytra at base, its sides converging toward apex; surface finely, transversely strigate; mesosternum compressed and much elevated.

Elytra slightly tapering toward apex and rounded at tip; sixth ventral segment visible, nearly truncate or very slightly emarginate; surface like pronotum; at apex are two short, narrow appendages, pointed at tip and covered with comparatively long seta-like hairs.

Length : $2.5 \mathrm{~mm}$.

Remarks.-This species somewhat resembles $D$. greeni Liljeblad, but differs slightly in size and color and notably in the shape of the male appendages, which in that species are gradually broadened to the apex and truncate. The type is in the Museum of Zoology, University of Michigan (Liljeblad coll.).

Previous Records.--Inyo Mountain, California (Liljeblad).

Material examined.-Arizona : Chiricahua Mountains, May 10 to June 9 (Hubbard and Schwarz, U.S.N.M.) ; Bill William Fork (Snow, K.U.).

\section{Diclidia inyoensis Liljeblad}

Diclidia inyoensis Liljeblad, 1921, p. 181, Inyo Mountains, California.

Description.-Body elongate, nearly parallel in male, more robust in female; head dark reddish brown; mouth parts fusco-testaceous, except for dark brown palpi; eyes black; antennae reddish brown, a little lighter toward base; pronotum and elytra dark reddish brown; undersurface dark brown, except prosternum in male, which is much lighter in color; legs testaceous in male, fusco-testaceous in female.

Head large, about one-third narrower than thorax; eyes rather coarsely granulated and emarginated behind antennae, not hairy ; antennae with first and second segments about equal in length, each one-fourth shorter than third, which is a little shorter than fourth in male; third and fourth segments equal in female and subequal in length to second segment, sixth to tenth segments in both sexes about equal in length, each widening toward 
apex and each shorter than fifth; eleventh segment pointed at tip, twice as long as tenth.

Pronotum one-third broader than long, broadest at base, its sides rapidly converging to apex; basal angles acute; surface finely, transversely strigate; mesosternum compressed and slightly elevated.

Elytra as wide as thorax at base, rather abruptly rounded at apex, especially in male; sixth ventral segment visible. The males have, on each side of the aedeagus, a rather long, flattened, dilated appendage, rounded at apex, and covered with setae (these appendages, however, can only be seen when the genital organ is extruded).

Length: (male) $2 \mathrm{~mm}$; (female) $2.25 \mathrm{~mm}$.

Remarks.-This species somewhat resembles Anthobates fusculus Leconte, but the antennae are longer, with the third and fourth segments about equal in length, the fourth not being reduced in size as it is in Anthobates. The type is in the Museum of Zoology, University of Michigan (Liljeblad coll.).

Prevrous Records.--Inyo Mountains, California (Liljeblad).

\section{Diclidia sordida, new species}

Type.-From Chiricahua Mountains, Arizona. A male, collected June 1-11 by Hubbard and Schwarz; in the collection of United States National Museum.

Allotype.-A female, same data as type.

Paratypes.-Eleven specimens, same data as type. Two from Santa Rita Mountains, Arizona, June 9-14; in the collections of United States National Museum and Museum of Zoology, University of Michigan (Liljeblad coll.).

DESCRIPTION.--Elongate; uniformly fusco-testaceous or fusco-rufous in male, fusco-piceous in female, legs a little paler.

Head rather large, about one-fourth narrower than thorax at middle; surface with minute transverse strigation; eyes moderately large, rather coarsely granulated, not hairy, and with a small emargination behind antennae; antennae very long, filiform, reaching nearly to middle of elytra; third and fourth segments equal in length, each as long as first and second combined; fifth to tenth about equal in length, each one-fourth shorter than fourth; sixth to tenth slightly dilated at apex; eleventh one-third longer than tenth, oval; last segment of maxillary palpi unusually long and narrow, with apical side nearly as long as outer.

Pronotum one-fourth broader than long, broadest at middle, evenly rounded to apex; surface transversely strigate; posterior angles subacute.

Elytra at base very little broader than thorax at base, surface trans- 
versely strigate and with very faint indications of two striae near suture in front of middle. Sixth ventral segment visible in male.

Length : $2.42-3.5 \mathrm{~mm}$.

Remarks.-This species does not resemble any of the other known species of Diclidia. It may be confused with Anthobates fuscula or Anaspis sericea, but the long antennae, with the third and fourth segments equal in length, each as long as the first two combined, separate this species from Pentaria or Anaspis.

\section{PENTARIA MULSANT}

Pentaria Mulsant, 1856, p. 391. J. B. Smith, 1882, pp. 74, 75. Blatchley, 1910, p. 1309. Mequignon, 1937, p. 278.

Anthobates Leconte, 1850 (nec Gistel, 1848), p. 231; 1862, p. $44 . \quad$ Liljeblad, 1918, p. 154. Anthobatula Strand, 1929, p. 23 (n. n. for Anthobates Leconte, nec Gistel).

Description.--Scutellum rounded triangular; last dorsal segment of abdomen not prolonged; sixth ventral segment visible; hind tibiae without ridges, more slender than in Anaspis; third segment of anterior and middle tarsi not lobed, fourth equal to third and emarginate; claws dilated at base. Hind coxae smaller than in Anaspis. Eyes coarsely granulated and with a small emargination; antennae with fourth to sixth segments short and seventh to eleventh thickened, not serrate; last segment of maxillary palpi triangular, acute at tip.

REMarks.-This genus differs from Diclidia in the antennal segments and in the not compressed mesosternum. The species are small, narrow, finely pubescent insects whose sculpture consists of very fine transverse lines.

\section{KEY TO SPECIES}

Color of elytra in bands or spots 2

Color of elytra uniform or nearly so ………............................................................................................................ 3

2. Body fuscous; head, thorax, feet and base of antennae testaceous; elytra yellow, with base, tip, and a median band black; length $3-4$ mm.; Pl. VII, Fig. 1.

(p. 197) trifasciata

Body narrow; yellow, with a broad fuscous band on the elytra at middle; length $2.5 \mathrm{~mm}$; Pl. VII, Fig. 2

(p. 198) trifasciata var. nubila

Subcuneate; with fine silvery pubescence; head and thorax testaceous or flavotestaceous; elytra black, with an oblong testaceous or flavo-testaceous humeral spot, reaching to near the middle of the elytra and an indistinct subapical pale spot; length $2.5 \mathrm{~mm}$.; PI. VII, Fig. 3

(p. 199) dispar

Subcuneate, rather robust, densely and very finely pubescent; head and thorax black; elytra testaceous or flavo-testaceous, with a dark scutellar cloud and narrowly black suture; legs testaceous, with femora darker; length $2.5-3 \mathrm{~mm}$.

(p. 199) bicolor

3. Body slender; pubescence fine; entirely fuscous or piceous; legs, mouth parts, and base of antennae paler; length $2.5-3.5 \mathrm{~mm}$.

(p. 200) fuscula

Body robust, pubescence coarse, fuscous; head, venter, legs, and antennae pale orange; length $1.5 \mathrm{~mm}$.

(p. 201) hirsuta

Moderately elongate; entirely testaceous or flavo-testaceous except the antennae, which are black; length $2-3 \mathrm{~mm}$. (p. 201) pallida 


\section{Pentaria trifasciata (Melsheimer)}

(PI. VII, Fig. 1)

Anaspis trifasciatus Melsheimer, 1845, p. 312, Pennsylvania.

Anthobates trifasciata, Leconte, 1850, p. 231.

Pentaria trifasciata, Leconte, 1862, p. 44 . J. B. Smith, 1882, p. 76. Blatchley, 1910, p. 1309.

Description.-Elongate; head, thorax, five basal segments of antennae, and palpi pale testaceous, six apical segments of antennae black; elytra testaceous or yellowish testaceous, with base, suture, a broad median band, and apex black; underside more or less fuscous; legs pale; surface covered with yellowish pubescence.

Head moderately large, minutely aciculate and punctured, finely strigate in circular lines; antennae with first and second segments large, third segment about as long as second but narrower at base; fourth and fifth segments subequal in length, each one-third shorter than third; sixth subequal in length to fifth, much broader at apex; seventh to tenth about equal in length, each not much longer than sixth but somewhat broader; last segment of maxillary palpi in male cultriform or somewhat like an isosceles triangle, with outer and apical sides about equal, in female scalene triangular; eyes coarsely granulated with a small emargination behind antennae.

Pronotum about one-third broader than long, minutely aciculate and punctured, finely and transversely strigate; hind angles nearly acute; sides evenly rounded to apex.

Elytra very little narrower than thorax; apex rounded; surface like thorax; sixth ventral segment visible. Male with two long appendages, one each side of aedeagus at base, slightly curved, dilated toward tip, bluntly rounded at apex, sparsely covered with hairs; these appendages cannot, however, be seen unless the genital organ is extruded.

Length : 3-4 mm.

REMARKs.-This species is very readily distinguished by the yellowish brown color and the black bands on the elytra. In some specimens these bands are less strongly indicated, although always present, and the middle band is the broadest. Some western specimens are rather chestnut brown, shining, and the yellow markings are also stained a little brown. Melsheimer's type, in the Museum of Comparative Zoology, agrees with the above description. The species seems to have a very wide range and is rather common in certain localities.

Previous records.-Pennsylvania (Melsheimer); Lake Superior (Leconte); Ohio (Dury); Montrose, Ouray, Fort Collins, Colorado Springs, Palmer Lake, and La Veta, Colorado (Wickham).

MATERIAL EXAMINED.-Arizona: Fort Grant (U.S.N.M.).

California : Carmel, June 15 (Hubbs). 
District of Columbia: Rock Creek (Hubbard and Schwarz).

Illinois: Palos Park, July 23 and Bowmanville, August 15 (Liljeblad);

Urbana and Quincy, July 3 (I.U.).

Indiana: Battle Ground, May 23 (Wolcott).

Iowa: Iowa City, June 25 (Stoner).

Kansas: Douglas County (Snow); Miami County (Beamer).

Kentucky : Frankfort, July 4 (Soltau, U.S.N.M.).

New Mexico : Jemez Mountains (Woodgate).

New York : New York City, July 4 (Soltau, U.S.N.M.).

Ohio : Columbus, July 14-20 (Liljeblad).

Oregon: Josephine County (Nunenmacher).

Pennsylvania: Philadelphia, July 11 (Myers, U.S.N.M.) ; Harrisburg, July 9 (Myers, U.S.N.M.).

Utah: Ogden Canyon, June 24 (Knaus).

\section{Pentaria trifasciata var. nubila Leconte}

(Pl. VII, Fig. 2)

Anaspis nubila Leconte, 1859, p. 78, Tejon, California.

Pentaria nubila Leconte, 1862, p. 44. J. B. Smith, 1882, p. 76.

Description.- "Linearis, flava pubescens, subtiliter dense punctulata, thorace latitudine fere duplo breviore, semicirculari, elytris fascia lata media interminata nigra, antennis nigris, basi flavis; subtus fusca, pedibus flavis ; long. '09', (Leconte).

REMARKS.-Except as indicated in Leconte's description this variety is like typical trifasciata Melsheimer.

This variety, judging from specimens that have been studied, is very closely allied to Pentaria $t$. trifasciata (Melsheimer). I have been unable to find any differences from that form except in color markings. Usually, the elytra have a dark band at the middle, which often does not reach the suture, but sometimes a specimen is found which has the apex also a little dark. This circumstance, as well as the fact that no differences can be found in the male appendages, has led me to believe it a color variety of trifasciata. It appears to be peculiar to the west and south, since no specimens from the middle and eastern states have been seen with this color difference, although hundreds of $t$. trifasciata have been collected. Leconte's type, in the Museum of Comparative Zoology, has been seen by me and found to agree with his above copied description. Pentaria nubila was described from Tejon, California, and all other records are from that state, except one from Florida.

Previous Records.-Tejon, California (Leconte).

Material examined.-Arizona: Catal Springs, May 4 (Hubbard and Schwarz, U.S.N.M.). 
California : Riverside, April 11 (I.U.) ; Los Angeles County (Coquillet) ; Isabella, Kern County (Ralph Hopping).

Florida: Paradise Key (U.S.N.M.).

Washington: Wenatchee, June 24 (Newcomer, U.S.N.M.).

Wyoming : National Park, July 31 (U.S.N.M.).

\section{Pentaria dispar (Liljeblad)}

(Pl. VII, Fig. 3)

Anthobatcs dispar Liljeblad, 1918, p. 154, Jemez Mountains, New Mexico.

Description.-Subcuneate, clothed with very fine silvery pubescence; head testaceous or flavo-testaceous; antennae with six basal segments testaceous; seventh to eleventh fuscous; eyes black; thorax testaceous or flavotestaceous; elytra black, with an oblong testaceous humeral spot, which reaches nearly to middle and an indistinct, paler, subapical spot; abdomen black.

Head moderately large; antennae with first and second segments nearly equal in length; second a little stouter; fourth to sixth equal in length; seventh to tenth gradually becoming wider distally ; eleventh elongate, onethird longer than tenth; last segment of maxillary palpi somewhat scalene, acute at tip ; eyes elongate, very slightly emarginate behind antennae, moderately granulated.

Pronotum widest at middle, then rapidly converging toward apex, subrectangular at base; surface finely, transversely strigate; mesosternum rather compressed and elevated.

Elytra nearly as broad as thorax at base; sides evenly curved to near apex; surface like thorax. The male bears two rather long and broad appendages, one each side of the aedeagus; these appendages are equal in width to apex, which is bluntly rounded.

Length : $2.5 \mathrm{~mm}$.

Remarks.-This species does not resemble any other of our species of Pentaria; it may be recognized by the humeral spot on the elytra. The type is in the Museum of Zoology, University of Michigan (Liljeblad coll.).

Previous Records.-Jemez Mountains, New Mexico (Liljeblad).

Material Examined.-Arizona: Globe, June 1 (Duncan); Oracle, June 29 to July 8 (Hubbard and Schwarz, U.S.N.M.) ; Chiricahua Mountains, June 9 (Hubbard and Schwarz, U.S.N.M.).

Virginia: Pennington Gap, July 2 (Hubbard and Schwarz, U.S.N.M.).

\section{Pentaria bicolor (Liljeblad)}

Anthobates bicolor Liljeblad, 1918, p. 155, Davis Mountains, Texas.

Description.-Subcuneate, rather robust, densely and very finely pubescent; head black; mouth parts and six basal segments of antennae testa- 
ceous; eyes black; prothorax black; elytra testaceous or flavo-testaceous, with a dark scutellar cloud and narrowly black suture; legs testaceous, femora darker; underside of body black.

Head moderately larg'e; antennae with first and second segments equal in length, rather broad; third to fourth segments about equal in length, each a little shorter than second; sixth a little shorter than fifth; seventh to tenth gradually increasing in width; eleventh elongate; last segment of maxillary palpi somewhat scalene triangular; eyes coarsely granulated and with a rather deep emargination behind antennae.

Pronotum one-third broader than long, rapidly converging from base to apex; basal angles obtuse; surface finely, transversely strigate.

Elytra a little narrower at base than thorax; surface similar to thorax; sixth ventral segment scarcely visible. The male has, on each side of the aedeagus, a rather short, narrow, elongate appendage, somewhat rounded at tip; this, however, can only be seen if the sexual organ is extruded.

Length : $2.5-3 \mathrm{~mm}$.

ReMARKS.-This species somewhat resembles Anaspis flavipennis in color, having the head and thorax black and the elytra paler. It differs, however, in the antennae and in the anterior and middle tarsi and by not having any abdominal appendages on the third segment. In dissecting specimens of this species for examination of the genitalia, I did not succeed as well as I did with other species in showing the complete structure, but so far as seen, the organ appeared to be somewhat as in Pentaria dispar, although shorter and broader at the apex. The species is recognized readily by its color. The type is in the Museum of Zoology, University of Michigan (Liljeblad coll.).

Previous records.-Davis and Chisos Mountains, Texas (Liljeblad).

\section{Pentaria fuscula Leconte}

Pentaria fuscula Leconte, 1862, p. 44, Texas and New Mexico. J. B. Smith, 1882, p. 76.

DESCRIPTION.-Elongate oval; black, with elytra a little browner; basal segments of antennae, palpi, and leg's yellowish testaceous; pubescence very fine, silvery gray.

Head moderately large, rather coarsely, circularly strigate and finely punctured; antennae about as long as head and thorax; first and second segments stout, equal in length; third segment about as long as second but more slender, elongate; fourth to sixth segments subequal in length, each one-fourth shorter than third and each a little broader toward apex; seventh to tenth each gradually broadened; last segment of maxillary palpi somewhat cultriform; eyes coarsely granulated and emarginated behind antennae.

Pronotum one-third broader than long, finely aciculate, punctures, and transversely strigate; basal angles rounded. 
Elytra about as broad as thorax; surface finely, transversely strigate; apex rounded; sixth ventral segment visible.

Length : $2-3 \mathrm{~mm}$.

Remarks.-This species is recognized by its uniform dark color and pale legs. In the specimens that I have examined, no special male appendages have been discovered. The color varies a little; some specimens have the elytra more brownish than black. Specimens have been taken on the flowers of Clematis ligustifolia. They are rather rare.

The supposed type or first specimen of this species in Leconte's collection, in the Museum of Comparative Zoology, is not considered by me to be the original type specimen. It is a female bearing a green tag which, according to the color key, means that it came from Kansas, Nebraska, Colorađo, or westward, whereas Leconte's description records Texas and New Mexico.

Previous records.-Texas and New Mexico (Leconte) ; from the following localities in Colorado: Upper San Juan, Durango, Big Narrows of Poudre, Dixon Canyon, Fort Collins, Livermore, Manitou, lower slopes of Pikes Peak (Wickham); and from the following places in New Mexico: Gallup (Wickham); Pecos and Glorieta (Cockerell); Cloudcroft (Knaus); Santa Fe (Fenyes); Alamogordo and Highrolls (Viereck).

Material examined.-California : Los Angeles (Coquillet, U.S.N.M.).

Colorado: Colorado Springs, August 27 (Soltau, U.S.N.M.) ; Pikes Peak (Soltau, U.S.N.M.).

New Mexico: Cloudcroft, August 9 (Knaus); James Spring (Miss E. W. Mank).

Texas: Jemez Mountains, July 27 (Woodgate).

\section{Pentaria hirsuta Smith}

Pentaria hirsuta Smith, 1882, p. 76, California.

DESCRIPTION.-

Body robust; pubescence coarse, fuscous; head, venter, legs, and antennae pale orange. $1.5 \mathrm{~mm}$; California.

Readily distinguished from the other species in this genus by the exceedingly small size, the robust form, and the long and unusually coarse pubescence. It is most nearly allied to fuscula. One specimen only; Coll. of Dr. Horn. (Smith)

Remarks.--This species is entirely unknown to me. I have been unable to locate the type and have seen no specimens that fully agree with the description.

\section{Pentaria pallida (Liljeblad)}

Anthobates pallidus Liljeblad, 1918, p. 156, New Mexico.

Description.-Moderately elongate; entirely testaceous or flavo-testaceous, except that the antennae have the five apical segments fuscous and 
that the eyes are black; densely and very finely covered with pale yellow or silvery gray pubescence.

Head moderately large, about one-third narrower than thorax; antennae with first to third segments about equal in length, first and second more robust; fourth and fifth about equal in length, each shorter than third; sixth to tenth gradually increasing in width; eleventh elongate, narrow, one-third longer than tenth; last segment of maxillary palpi somewhat scalene triangular, concave on distal margin, pointed at tip; eyes rather coarsely granulated, with a shallow emargination.

Pronotum one-third broader than long; sides evenly rounded from base to apex; apical angles subacute; a slight impression present on middle of each side; surface finely, transversely strigate.

Elytra a little broader than thorax at base; surface like pronotum. The male has two short appendages, one on each side of the aedeagus, very narrow at base, rather abruptly broadened and rounded at apex, and hairy; sixth ventral segment scarcely visible.

Length : 2-3 mm.

Remarks.-This species somewhat resembles Pentaria bicolor (Liljeblad), but differs notably in the color of the head, thorax, and undersurface, which are black in that species. The type is in the Museum of Zoology, University of Michigan (Liljeblad coll.).

Previous records.--Jemez Mountains, New Mexico (Liljeblad).

Material EXAMined.-Arizona : Chiricahua Mountains, May 8 to July 29 (Hubbard and Schwarz, U.S.N.M.) ; Catal Spring, May 5 (Hubbard and Schwarz, U.S.N.M.) ; Santa Rita Mountains, June 14 (Hubbard and Schwarz, U.S.N.M.) ; Tucson, May 1 (Hubbard and Schwarz, U.S.N.M.).

California : Los Angeles County (Coquillet, U.S.N.M.).

Colorado: Garden of the Gods, July 5 (Miss E. W. Mank).

Kansas: Hodgeman County, July 17-25 (K.U.) ; Rawlins County (Williams, K.U.) ; Douglas County, August (Hoffman and Tucker, K.U.).

New Mexico: Jemez Springs (Miss E. W. Mank); Gallup (Linell, U.S.N.M.).

Texas : Brownsville, June 5 (Hubbard and Schwarz, U.S.N.M.) and September 19 (I.U.).

\section{NAUCLES CHAMPION}

Naucles Champion, 1891, p. 257. Type: Naucles tibialis.

DESCRIPTION.-The chief characters given by Champion for this genus are as follows: mandibles toothed; last segment of maxillary palpi very obliquely truncate at apex and acuminate; mentum strongly transverse; antennae short, somewhat clavate, apical segments transverse; eyes coarsely granulated; fourth segment of anterior and middle tarsi bilobed, as broad 
as, but shorter than, the third; all tibiae short and compressed, considerably dilated toward apex, posterior pair not longer than, or scarcely as long as, first two segments of posterior tarsi united; upper surface very densely and minutely punctured, with only faint strigation on pronotum and extreme base of elytra; ventral segments similar in both sexes, sixth covered by fifth; body oblong, subovate.

REMARKs.-Only three species of the present genus occur, so far as is known, in North America. One of these, N. pusio, has hitherto been placed erroneously under Anaspis, to which genus it cannot belong, since the male does not possess any external appendages on the third abdominal segment.

The characters of this genus are very nearly those of Pentaria, but the short dilated tibiae, the very slender and acuminate apical segment of the labial palpi, and the very stout second segment, preclude association with that genus. The four anterior tibiae are broader at the apex and more compressed than in Anaspis, and the hind pair are similarly shaped. The general shape is shorter and more ovate than in Pentaria. In the sculpture of the upper surface this genus differs from all other genera of Anaspini in that there is searcely a trace of transverse strigation on the greater part of the elytra.

\section{KEY TO SPECIES}

Upper surface uniform in color 2

Upper surface not uniform in color 3

2. Entirely pale yellowish brown; Pl. VII, Fig. 4 ......................................................... (p. 203) pusio

Entirely testaceous or reddish testaceous (p. 204) tibialis

3. Head and thorax fusco-ferruginous, the latter with a dark cloud at middle; elytra piceous with a faint oblique reddish spot near base and one near the apex; $\mathrm{Pl}$. VIT, Fig. 5 (p. 205) basalis

\section{Naucles pusio (Leconte)}

(PI. VII, Fig. 4)

Anaspis pusio Leconte, 1858, p. 76, California; 1862, p. 45. J. B. Smith, 1882, pp. 77, 78.

Description.-Oblong ovate; entirely pale yellowish brown, covered with silky yellowish pubescence.

Head about half as broad as thorax, very minutely, transversely strigate and punctured; antennae short, reaching to about base of thorax; third to sixth segments short, narrow; seventh to eleventh much broader, forming an elongate club; ninth segment broadest; last segment of maxillary palpi cultriform, pointed; eyes coarsely granulated, broadly emarginated behind antennae.

Pronotum nearly twice as broad as long; surface minutely, transversely strigate and punctured; basal angles obtuse; base at middle broadly rounded; scutellum at apex rather broadly rounded. 
Elytra a little broader than thorax at base, evenly rounded to near tip; surface finely, transversely strigate only near base; remainder finely punctured; tibiae on all legs broadly dilated toward apex.

Length : $1.25-1.5 \mathrm{~mm}$.

Remarks.-Leconte's type from California, in the Museum of Comparative Zoology, agrees with the above description. It does not have any abdominal appendages on the third (or fourth) ventral segment and is scarcely at all strigate on the greater part of the elytra. It cannot, therefore, be placed in the genus Anaspis.

This is one of the smallest species of Anaspini in North America and is very easy to distinguish by its pale color. It appears only in the western states from April to September. The males can scarcely be separated from the females unless the genitalia are extruded. The aedeagus sheet is elongate and at its apex appear several both long and short bristle-shaped appendages.

Previous Records.-Fort Yuma, California, and Colorado Desert (Leconte); Galinas Canyon, New Mexico (Snow).

Material examined.-Arizona: Winslow (Wickham); Nogales, Santa Cruz, August 30 (Nunenmacher) ; Adamana, July 12 (Miss E. W. Mank).

California: Brawly, Imperial County, August 8 (Bradley); Pasadena, April (Fenyes) ; Jamul, May 10 (Hubbs); Willow Creek, Humboldt County, June 12 (Psota) ; Furnace Creek Ranch, Death Valley, August 16 (" R \& H') ; Riverside, July 17 (Miss E. W. Mank).

Texas: San Diego, April 24 (E. A. Schwarz, U.S.N.M.).

Utah: American Fork, June 24 (Hubbard and Schwarz, U.S.N.M.).

\section{Naucles tibialis Champion}

Naucles tibialis Champion, 1891, p. 257, Guatemala.

Description.-Oblong, ovate; entirely testaceous or sometimes reddish testaceous; upper surface densely covered with fine silky pubescence.

Head comparatively large, very minutely aciculate and somewhat circularly strigate; antennae rather long, reaching to base of thorax when head is extended; first and second segments large, oblong, subequal in length; third to sixth segments very small, the first being the smallest; seventh to eleventh much longer and broader, forming an elongated club ; last segment of maxillary palpi somewhat cultriform, with inner side as long as apical, which is pointed; labial palpi with second segment stout and ovate, apical segment slender and pointed; eyes coarsely granulated and emarginate behind antennae.

Pronotum one-half broader than long, evenly rounded to apex; hind angles subacute; surface minutely aciculate and transversely strigate.

Elytra a little broader at middle than thorax, gradually tapering to apex, 
which is rounded; surface transversely strigate only at base, otherwise reticulate. All the tibiae are dilated toward the apex. No sexual characters have been discovered.

Length : 1.25-1.5 mm.

REMARIKS.-This species was described from Guatemala and has not been recorded before from the United States. It is very small and is perhaps best recognized by its color.

Naucles quercus Champion seems to be very closely allied to the present species, so much so that I am unable to separate the two by their descriptions. The specimens at hand, however, all agree very well with tibialis.

Previous ReCords.-Guatemala (Champion).

Material examined.-California: Alameda County, January, 1890 (Koebele).

\section{Naucles basalis Champion}

(Pl. VII, Fig. 5)

Naucles basalis Champion, 1891, p. 257, Guatemala.

DESCRIPTION.--Oblong ovate; head and thorax fusco-ferruginous, latter with a dark cloud at middle; antennae and palpi a little paler; elytra piceous, densely covered with silvery gray pubescence and having a very faint oblique reddish spot a little below base, not reaching sides or suture, and a similarly colored area near apex, which in some specimens is extended to sides; underside dark.

Head comparatively large; sculpture on vertex circularly strigate; antennae short, somewhat clavate; first and second segments long; third to sixth segments very small, the four altogether about as long as first two combined; seventh to tenth much broader, forming a club; the eleventh oval; last segment of maxillary palpi narrow, cultriform, pointed at tip; eyes coarsely granulated and emarginated behind antennae.

Pronotum nearly twice as broad as long, gradually rounded to apex; hind angles nearly acute; surface finely, transversely strigate; scutellum triangular.

Elytra at base about as broad as pronotum, finely, transversely strigate only at base, or on about basal one-fourth; otherwise reticulated and minutely punctured; anterior tibiae broadly dilated and rounded at apex.

Length : $1.5 \mathrm{~mm}$.

Remarks.-Two specimens of this species have been examined. These agree so closely with Champion's description that I do not find them worthy of a new specific name. It is rather difficult to distinguish the shape of the reddish elytral spots, for they can be seen only in a certain light or if the elytra are raised. The two specimens at hand differ slightly in color, the one from Katherina being much lighter. 
Previous Records.-Capetillo and San Geronimo, Guatemala (Champion).

Material examined.--Texas: Brownsville, August 31, and Katherina, December 3.

\section{SPHINGOCEPHALUS, NEW GENUS}

Description.-Small, oblong-oval; head compressed in front of eyes, neck deeply inserted in the thorax. Antennae inserted at middle in front of the eyes and gradually broadened to tenth segment. Last segment of maxillary palpi long, somewhat cultriform, inner side very short. Labial palpi with second segment small, oblong-oval, and narrow at base, apical segment crescent-shaped. Abdomen with sixth ventral segment visible. Upper surface very finely, transversely strigate; otherwise like Naucles.

REMarks.-This genus differs from Naucles mainly in the shape of the labial palpi which, in that genus, have the second segment very stout and the apical segment slender and acuminate; also in having the elytra strigate only at base.

The type of the genus is the following new species.

\section{Sphingocephalus ovalis, new species}

(Pl. VI, Fig. 19)

Type.-From Biscayne, Florida. A male, collected on May 16-25 by Hubbard and Schwarz; in the collection of United States National Museum.

Allotype.-A female, same data as type.

Paratypes.-Three males, same data as type; two in the Museum of Zoology, University of Michigan (Liljeblad coll.).

DESCRIPTION.-Oval; entirely testaceous except the black eyes; entirely covered with somewhat long, yellowish pubescence.

Head small, very compressed in front of the eyes, neck inserted deep into thorax, not visible unless head is extended; surface very minutely aciculate and punctured, faintly, transversely strigate between the eyes; antennae short, reaching to base of thorax when head is extended; first and second segments oblong oval; third to tenth segments gradually increasing in length and width; eleventh segment twice as long as tenth, oval; last segment of maxillary palpi elongate, apical side nearly as long as outer, inner side onehalf length of broadest part; last segment of labial palpi crescent-shaped; second segment small, oblong-oval, narrow at base; eyes oval, rather coarsely granulated, emarginated behind antennae.

Pronotum one-half broader than long, a little broader than elytra at base; sides gradually decreasing in width to apex; basal angles nearly acute; basal lobe at middle not very prominent; surface transversely strigate.

Elytra broadest at middle and tapering to rounded apex; surface trans- 
versely strigate and finely punctured, more strongly near base. Abdomen with sixth segment very faintly visible. The male has a peculiar, ornamented aedeagus sheath, on each side of which is seen, when viewed from above, a broad appendage with four points, open in the middle; this is not seen unless the genitalia are extruded.

Length: $2 \mathrm{~mm}$.

REMARKS.-This species is unlike any other form of North American Anaspini. It is darker than Naucles pusio and otherwise differs from that species by having the entire elytra transversely strigate and by having the last segment of the labial palpi crescent-shaped.

\section{ANASPIS GEOFFROY}

Anaspis Geoffroy, 1762, p. 315. Costa, 1854, p. 28. Back, 1856, p. 253. Mulsant, 1856, p. 87. Leconte, 1862, p. 44. Emery, 1876, p. 8. J. B. Smith, 1882, pp. 74, 76. Schilsky, 1899, p. D. Blatchley, 1910, pp. 1309, 1310.

Description.-Last segment of maxillary palpi cultriform, more or less elongated; that of labial palpi largely triangular; mandibles bifurcated; labrum square, transverse; head subrounded; eyes oval, oblique, reaching occiput, emarginated behind antennae; antennae slightly subfiliform, enlarging toward tip; prothorax transverse, truncate in front, with anterior angle bent downward, and with a very short median lobe; scutellum small, triangular; elytra truncate at base, gradually attenuated toward tip ; posterior tibiae slightly thickened; fourth segment of anterior and middle tarsi very small, received upon the third segment, which is lobed; transverse strigation very fine.

The males are distinguished from the females by the presence of movable appendages, which proceed from the apex of the third abdominal segment at the middle, except in $A$. rufa (which has a short second pair proceeding from the apex of the fourth segment), and by having the last segment more or less cleft or emarginate at apex.

REMARKS.-Leconte, in his Synopsis (1862: 44), said that "in the male two long slender appendages are seen proceeding from between the fourth and fifth ventral segments"; J. B. Smith, in his Synopsis (1882: 77), followed Leconte but admitted "that he had been entirely unable to discover these processes, although he had examined hundreds of specimens of $A$. rufa to this end alone. Males I found with the excavated ventral segment, but never the processes." Schwarz (1890: 76, 77) gave a very interesting account of these processes in Anaspis and their structure and said: "It seems strange that there should be such difference of opinion regarding this character in our Anaspis, which by no means rank among the smallest Coleoptera, but the superficial appearance of this structure is, indeed, a most deceptive one." He must have overlooked the real starting point of these processes 
and should not have followed Leconte and Smith in saying that they arise from the apex of the fourth ventral segment. All species formerly placed in the North American genus Anaspis (except pusio, which does not belong to this genus), have the appendages proceeding from the apex of the third abdominal segment, not from the fourth.

\section{KEY TO SPECIES}

Abdominal segment in male with two movable appendages .............................................................. 2

Abdominal segment in male with four movable appendages .................................................................. 9

2. Upper surface entirely black .......................................................................................................................... 3

Upper surface partly black .................................................................................................................................... 4

3. Thorax twice as broad as long ……………................................................................ (p. 208) nigrina

Thorax one-half broader than long; Pl. VII, Fig. 6 ...................................... (p. 209) atrata

4. Elytra not black ....................................................................................................................................................... 5

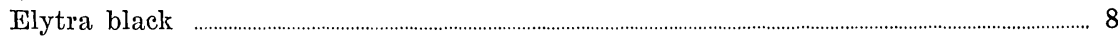

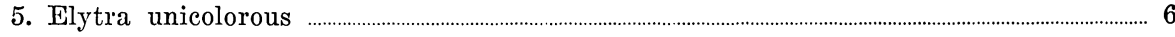

Elytra bicolored ...................................................................................................................................................... 7

6. Elytra brownish black; abdominal appendages short, reaching a little below the apex of the fourth segment; Pl. VII, Fig. 7 ................................................ (p. 211) seposita

Elytra piceous brown; abdominal appendages long; Pl. VII, Fig. 8 (p. 212) sericea

Elytra brownish yellow; Pl. III, Fig. 9 .................................................... (p. 213) flavipennis

7. Elytra with a large testaceous basal spot; Pl. VII, Fig. 10 .................... (p. 214) militaris

Elytra fusco-ferruginous with a dark basal cloud; Pl. VII, Fig. 11 ........ (p. 216) duryi

8. Thorax with basal angles testaceous; Pl. VII, Fig. 12 .............................. (p. 214) beardsleyi

Thorax entirely yellow-testaceous; Pl. VII, Fig. 13 .................................... (p. 215) collaris

9. Head, thorax, and elytra brownish yellow ; Pl. VII, Fig. 14 ................................. (p. 217) rufa

\section{Anaspis nigrina (Csiki)}

Hallomenus nigra Haldeman (nec Mordella nigra Rossi, 1792, p. 55) = Anaspis nigra

(Rossi), 1848, p. 99, Upper Mississippi.

Anaspis nigra, Leconte, 1862, p. 45. J. B. Smith, 1882, p. 77.

Anaspas nigrina (Csiki), 1915, p. 69 (n. n.).

\section{DESCRIPTION.-}

Shining black, sparsely clothed with fine prostrate hair; mouth and antennae (?) brown: prothorax impunctate and with the elytra finely pubescent, the latter minutely and obsoletely scarious. 1 $\frac{1}{2}$ L. long. Upper Mississippi. (Haldeman)

REMARKs.-Haldeman's description differs a great deal from the following description by Leconte :

Body entirely black; transverse striae exceedingly fine: Thorax twice as wide as long; base of antennae, palpi and front legs testaceous, 13-15, L. Superior and Hudson's Bay Terr. Male with the ventral segments broadly channeled. Hallomenus niger Hald.

The type of this species has not been found by me and is probably destroyed. The first three specimens of this species in the Leconte collection have the thorax twice as broad as long, but have no indication of abdominal appendages. The next four are Anaspis atrata Champion. 
Schwarz (1890: 76, 77), in his note on North American species of Anaspis, said that he has seen the male of Anaspis nigra with two slender abdominal appendages, but he did not remember in what collection.

I am unable to tell from the short description of Haldeman whether the above nigrina really belongs to the genus Anaspis, but take it for granted that Leconte, before placing it in that genus, probably saw the type before redescribing the species.

Seven specimens, five males and two females, are at Ohio State University, in the H. W. Wenzel collection. These seven specimens, collected at Robson, British Columbia, July 7, by F. R. Mason, will, no doubt, prove to be the long missing Hallomenus nigra Haldeman, although his description does not fully agree with the specimens at hand, for nothing is mentioned in regard to sexes and the usual appendages on the abdominal segments in the male and shape of the prothorax. Leconte, however, gave the shape of the thorax and said "male with the ventral segments broadly channeled," which may so appear if the appendages are placed close to the segments. The following description will serve for purposes of identification.

Entirely shining black, except clypeus, basal segments of antennae, palpi, and anterior leg's, which are more or less fusco-testaceous; surface with fine, silky, grayish white pubescence, which on male is a little brownish in color. Male somewhat cuneate, about one-fourth narrower than female, which is more parallel in shape.

Head finely scabrous; antennae subfiliform, a little longer than head and thorax; last segment of maxillary palpi somewhat cultriform, apical side nearly as long as outer; eyes rather coarsely granulated and emarginated behind antennae.

Pronotum about as broad as long in male, twice as broad as long in female; surface minutely punctured and transversely strigate; scutellum rather broadly triangular.

Elytra scarcely narrower than pronotum; surface finely, transversely strigate and minutely punctured; posterior tibiae in male one-fourth longer than first segment of tarsi, in female nearly twice as long; the male has two long, slender, movable appendages, pointed at apex and extending from middle of the third abdominal segment at apex, very slightly separated at base and diverging to apex of fifth abdominal segment.

Length : $2.5-3 \mathrm{~mm}$.

\section{Anaspis atrata Champion}

(Pl. VII, Fig. 6)

Anaspis atra Leconte (nec Fabricius, 1792, p. 115), 1851, p. 157, California; 1862, p. 45.

J. B. Smith, 1882, p. 77.

Anaspis atrata Champion (nec atra Leconte), 1891, p. 259.

Description.-Entirely black, except clypeus, three basal segments of antennae, and palpi, which are more or less fusco-testaceous. 
Head rather coarsely punctured and somewhat rugose; antennae subfiliform, a little longer than head and thorax; fourth segment about one-fourth longer than third; fifth to tenth subequal in length, each one-third shorter than fourth; seventh to tenth a little thickened outwardly; last segment of maxillary palpi cultriform; eyes coarsely granulated and emarginated behind antennae.

Pronotum one-half broader than long in male, in female nearly twice as broad as long; surface coarsely punctured and transversely strigate; basal angles obtuse; scutellum triangular.

Elytra a little broader than pronotum; surface transversely strigate and finely punctured; posterior tibiae very little longer than first segment of posterior tarsi; male with two long, slender, movable appendages extending from middle of apex of third abdominal segment, slightly separated at base and diverging somewhat to apex of fifth abdominal segment; these appendages are as long as fourth and fifth abdominal segments combined, broadest at base and gradually narrowed to a point; fifth abdominal segment rather deeply emarginated and depressed from emargination to base.

Length : $2.75-3 \mathrm{~mm}$.

REMARKS.-This species is almost entirely black and, aside from its color, may be recognized only by the structure and possession of the male appendages, which lie nearly parallel or slightly divergent. To judge from its color it may be closely allied to Anaspis nigrina Champion, from which it has been separated by previous writers only by its narrower thorax and less robust form. I have examined the type of atrata in the Museum of Comparative Zoology; it agrees with the above description.

Previous RECords.-California (Leconte) ; Colorado (Smith); and from the following localities in Colorado: Durango, Little Willow Creek, Montrose, Dolores, Ouray, Veta Pass, La Veta, South Park, Dome Rock, Micaber Mine, Estes Park, Little Beaver, Rocky Ford, Georgetown, Beaver Brook, Bowditch, Pike's Peak, Colorado Springs, Breckenridge, and Leadville (Wickham).

MAterial EXAmined.-Alberta : Banff, August 11 (Bradford, A.M.N.H.).

British Columbia: Carbonate, July 7 (Bradley); Kaslo, June 17 to July 16 (Caudell, U.S.N.M.) ; and Princeton, July 30 (Hopping).

California : Madera County, July 18 (Dietrich) ; Camp Baldy, Los Angeles, June 15 (Muchmore); Carmel, June 18 and Mount Diablo, July 15 (Hubbs); Pasadena, June (Fenyes); Mariposa and Humboldt counties, May 3, June 3 (Nunenmacher) ; Tahoe, August 24 (Miss E. W. Mank) ; Santa Cruz Mountains (Koebele); Los Angeles County, June (Coquillet); Santa Anna River, June 23 (I.U.) ; and Scotia, May 20 (H. S. Barber, U.S.N.M.).

Canada: Beaverfoot Range, Rocky Mountains (Wenman, A.M.N.H.). 
Montana : Missoula (Adams).

New Mexico: Cloudcroft, June 12 (Knaus) and Jemez Mountains, June 18 (J. W. Green).

Oregon : Gold Hill (Biedermann, U.S.N.M.).

Utah: Mammoth Top, Parawan Mountains (Knaus, Nidinger, and Hoover).

Washington : Easton (Koebele) and Tenino (U.S.N.M.).

\section{Anaspis seposita, new species}

(Pl. VII, Fig. 7)

Type.--From Hope, British Columbia. A male, collected on August 7, 1893 ; in the collection of the American Museum of Natural History.

PARATYPES.-Four males, same data as type; two in collection of the American Museum of Natural History, two in the Museum of Zoology, University of Michigan (Liljeblad coll.).

Description.-Moderately elongate; black or brownish black, above densely covered with fine, silky, grayish white pubescence; head before antennae, maxillary palpi, and three or four basal segments of antennae yellowish; apical segments of antennae and legs more or less brown.

Head finely, circularly strigate; antennae long, four segments reaching below thorax, subfiliform, slightly thickened externally; fourth segment longest, one-fourth longer than third and one-third longer than fifth segment; sixth to tenth each subequal to fifth in length; eleventh a little longer than tenth, oval; last segment of maxillary palpi cultriform; eyes somewhat coarsely granulated, emarginated behind antennae.

Pronotum one-third broader than long; surface finely, transversely strigate; basal angles obtuse; basal lobe in front of scutellum broadly rounded; scutellum triangular, rounded at apex.

Elytra nearly parallel to near apex; surface finely, transversely strigate and punctured; elytra not covering fifth abdominal segment. Male with two short, movable appendages extending from middle of apex of third abdominal. segment and not separated at base; these appendages broadest at base and very little curved to a point at tip, very hairy and in normal condition very little or not at all separated, reaching to a little beyond apex of fourth abdominal segment; fifth abdominal segment somewhat hollow at middle to near base and rather deeply emarginated at apex; no female has been available for study.

Length : $2.5 \mathrm{~mm}$.

REMARKs.-This species resembles a very small Anaspis atrata, but that species does not have the brownish tint on the elytra and the abdominal appendages are much longer, being more divergent and reaching to the apex of the fifth abdominal segment. 


\section{Anaspis sericea Mannerheim}

(Pl. VII, Fig. 8)

Anaspis sericea Mannerheim, 1843, p. 288, Sitka. Leconte, 1862, p. 45 . J. B. Smith, 1882, pp. $77,78$.

Anaspis luteipennis Leconte, 1851, p. 157.

Description.-Head black; mentum testaceous; antennae with first to fourth segments testaceous; fifth to eleventh black; palpi testaceous; thorax black, with fine gray pubescence; elytra piceous brown, darker at suture; underside black; anterior and middle legs fusco-testaceous, posterior legs darker.

Head somewhat shining, rugose and minutely punctured; antennae with first to eighth segments subfiliform; ninth to eleventh widened; third and fourth segments longest, each nearly as long as first and second combined; fifth one-fourth shorter than fourth; sixth to tenth about equal in length, each a little shorter than fifth; last segment of maxillary palpi somewhat cultriform; eyes rather coarsely granulated and emarginated behind antennae.

Pronotum one-fourth broader than long, surface rather coarsely, transversely strigate and finely punctured; basal angle subacute, basal lobe broadly rounded at middle in front of scutellum.

Elytra a little broader than thorax, evenly rounded to apex; surface rather strongly, transversely strigate and finely punctured, covered with fine yellowish gray pubescence. Male with two long appendages extending from middle of apex of third abdominal segment, united at their origin and slightly divergent and curved to apex; these appendages are movable, gradually widen toward apex, and are covered sparsely with fine hairs; fourth abdominal segment with a very small emargination at middle; fifth cleft one-fourth from apex and from there narrowly excavate to near base; female a little broader, but otherwise like male, with no appendages and no excavation on fifth ventral segment.

Length : $2.5-2.75 \mathrm{~mm}$.

RemarKs.-Only a few specimens of this species have been examined that fully agree with the original description by Mannerheim; the type has not been examined. Specimens are recognized by the black head and thorax and the dark brown elytra. Apparently they are very rare.

Previous Records.--Sitka, Alaska (Mannerheim).

Material examined.-British Columbia: Whitmans Creek, Vernon, July 1 (R. Hopping) ; Vancouver Island (Hy. Edw. coll., A.M.N.H.).

California: Carmel, June 13 (Hubbs); Toulumne, May 13 (Nunenmacher) ; Siskiyou County, July (Koebele, U.S.N.M.).

Idaho: Fort Sherman, June (Merrill), U.S.N.M.).

Oregon : Portland (U.S.N.M.).

Washington : Easton (Koebele, U.S.N.M.). 


\section{Anaspis flavipennis Haldeman \\ (Pl. VII, Fig. 9)}

Anaspis flavipennis Haldeman, 1848, p. 100, Lake Superior. Leconte, 1862, p. 45. J. B. Smith, 1882, pp. 77, 78. Blatchley, 1910, p. 1310.

DESCRIPTION.-Head black; mentum fusco-testaceous; antennae black, with four basal segments fusco-testaceous ; palpi testaceous; prothorax black, covered with rather long, silky, grayish white pubescence; elytra brownish yellow; underside black; all femora black, tibiae and tarsi paler.

Head strongly, transversely strigate; antennae thickened externally; third segment longest, nearly one-third longer than fourth ; fifth one-fourth shorter than fourth; sixth to tenth beadlike, about equal in length, much broader than fourth; last segment of maxillary palpi small, cultriform; eyes rather coarsely granulated and with a deep triangular emargination behind antennae.

Pronotum nearly twice as broad as long, transversely strigate and finely punctured; hind angles subacute.

Elytra a little broader than pronotum, transversely strigate and finely punctured. Male with two long, movable appendages extending from middle of apex of third abdominal segment, united at base and very slightly divergent to apex; these appendages as long as fourth and half of fifth abdominal segments combined, broadest from base to middle, then tapering to apex, densely covered with fine hairs; fifth segment cleft to near middle and very feebly excavated to base; fourth very narrowly excavated at middle from base to apex. Female like male but without abdominal appendages or excavation.

Length : $2.5-3 \mathrm{~mm}$.

REMARKS.-This species is rather common, especially in the eastern United States. It somewhat resembles Anaspis sericea, but the elytra are paler and the antemnae are entirely different; the sixth to tenth segments are beadlike, and the thorax is much broader.

Previous Records.-Lake Superior (Haldeman); Georgia and Minnesota (Leconte); New York (Smith); New York state (Nicolay); Rist Canyon, Colorado (Wickham); Steuben, Marion, Putnam, and Jennings counties, Indiana (Blatchley).

Material examined.-British Columbia: Boisdale, July 18 (A.M.N.H.).

Illinois: Edgebrook, June 14 (Liljeblad); Algonquin (Nason coll., I.S.N.H.S.).

Maine: Paris, Wales, Aziscoos Lake, and Monmouth, June 15 to July 13 (Frost) ; Rangeley, August 15 (A.M.N.H.).

Massachusetts : Framingham and Hopkinton, April 27 (Frost).

Michigan : Detroit, May 30 (Wolcott).

New Hampshire: Durham, June 29 (I.U.).

New York: Ringwood and Ithaca, May 24 (Dietrich). 
Nova Scotia: Truro, July 26 (Matheson).

Pennsylvania: Hummelstown and Carlisle Junction, May 3 to June 27 (Knull) ; Rockville, May 4 (Champlain) and May 20 (Craighead) ; Ognota and Darby, May 9 to 17 (J. W. Green).

Virginia: Fredericksburg, May 7 and June 30 (Richardson, U.S.N.M.).

\section{Anaspis militaris Smith}

(Pl. VII, Fig. 10)

Anaspis militaris Smith, 1882, p. 77, California; 1883, p. 3.

DESCRIPTION.-Head black; mentum rufo-testaceous; antennae black, three or four basal segments rufo-testaceous; palpi testaceous; thorax black; elytra with entire apical half and suture black, remainder testaceous or with a large basal spot testaceous ; epipleura testaceous ; underside black ; anterior legs testaceous, middle and posterior legs darker.

Head somewhat coarsely punctured and with fine gray pubescence; antennae with sixth to tenth segments gradually thickened; first to fifth segments narrow, equal in length, each a little longer than sixth; last segment of maxillary palpi cultriform, apical side nearly as long as outer; eyes coarsely granulated and emarginated behind antennae.

Pronotum a little broader than elytra at base, one-third broader than long; surface finely, transversely strigate and minutely punctured, covered with fine, silky gray pubescence; basal angle obtuse; basal lobe truncate at middle in front of scutellum; scutellum triangular.

Elytra broadest at middle; surface finely, transversely strigate and finely punctured. Male with two long appendages extending from middle of apex of third abdominal segment, united at base, slightly divergent and somewhat curved at apex; these appendages as long as fourth and fifth abdominal segments combined, about equal in width midway and then obliquely tapered to tip and covered with fine hairs; fourth and fifth abdominal segments broadly, triangularly emarginate at apex or nearly $V$-shaped; color of female like that of male, but basal spot smaller and nearer humeral angles and abdominal segments without emargination at middle.

Length : $3 \mathrm{~mm}$.

REMARKs.-This species can readily be distinguished by the testaceous basal spot on the elytra. The type has not been located.

Previous RECORDS.-California (Smith).

Material exAmined.-California: Shasta County, June 2, and Sonoma County, May 19 (Nunenmacher).

\section{Anaspis beardsleyi, new species}

(Pl. VII, Fig. 12)

TrPe.-From Paradise Valley, Kings River, California. A male, col- 
lected on July 18 by R. L. Beardsley, to whom the species is dedicated; in the Museum of Zoology, University of Michigan (Liljeblad coll.).

Description.-Head black, with mentum testaceous; antennae with four basal segments testaceous ; fifth to eleventh segments black; palpi testaceous ; thorax black, with basal angles and underside testaceous; elytra and undersurface black; anterior legs testaceous, middle and posterior femora black, tibiae and tarsi fuscous.

Head finely punctured, slightly rugose, and with fine gray pubescence; antennae with four apical segments dilated; first and second segments short, third and fourth long, each nearly as long as first two segments combined; fifth one-fourth shorter than fourth; sixth to tenth equal in length, each a little shorter than fifth; eleventh oval; last segment of maxillary palpi cultriform; eyes coarsely granulated, emarginated behind antennae.

Pronotum one-third broader than long, very finely, transversely strigate, minutely punctured and covered with fine gray pubescence; basal angles obtuse; basal lobe broadly rounded at middle in front of scutellum; scutellum triangular.

Elytra finely, transversely strigate, rather closely covered with fine gray pubescence. Male with two long appendages extending from middle of apex of third abdominal segment, united at base and divergent to apex; these nearly as long as fourth and fifth abdominal segments combined, slightly curved and about equal in width throughout, sparsely covered with fine hairs; fifth abdominal segment emarginated one-third from apex and from there excavated to near base.

Length : $2.5 \mathrm{~mm}$.

REMArKs.-Only one male specimen of this interesting species has been seen. The light spot at the basal angles of the thorax distinguishes this from other species.

\section{Anaspis collaris Leconte}

(Pl. VII, Fig. 13)

Anaspis collaris Leconte, 1851, p. 157, San Diego, California; 1862, p. 45 . J. B. Smith, 1882, pp. 77, 78.

DEscription.-Head black; clypeus yellow testaceous; antennae with three or four basal segments testaceous; palpi testaceous; prothorax yellow testaceous; elytra black, covered with very fine, silky, yellowish gray pubescence; body beneath black; anterior legs more or less testaceous; middle and posterior legs darker, in female black.

Head finely, transversely strigate or somewhat rugose; antennae long; four or five segments reaching below thorax, subfiliform; outer segments dilated; fourth segment longest, one-third longer than third; all other segments subequal in length, except eleventh, which is a little longer than tenth and oval; last segment of maxillary palpi cultriform; eyes coarsely granulated and emarginated behind antennae. 
Pronotum very little broader than long, transversely strigate and finely punctured; hind angles subacute; basal lobe broadly rounded at middle; scutellum triangular.

Elytra a little broader than thorax, gradually tapering to apex, transversely strigate and finely punctured. Male with two long movable appendages extending from middle of apex of third abdominal segment, very slightly separated at base; these appendages about equal in width and nearly straight to middle, then curved outward and inward to apex, reaching nearly to apex of fifth abdominal segment; fifth abdominal segment emarginated at apex or cleft and slightly hollowed at middle; female like male, but with antennae a little shorter and abdominal segments without appendages.

Length : $3.25 \mathrm{~mm}$.

REMARKs.-This species is readily recognized by the black head and elytra and the pale thorax. Apparently, it is rather rare and only a few specimens have been available for study. The type, from California, is in the Leconte collection, in the Museum of Comparative Zoology, and agrees with the above description.

Previous Records.-San Diego, California (Leconte); Santa Catalina, California (Fall).

Material examined.-California: Pine Hills, June 29 (Psota); Giant Forest, July 21-26 (Bradley) ; San Gabriel, June 5 (Grinnell, Jr.) ; Paradise Peak, July 19 (Beardsley); Strawberry Valley, July 17 (Frost); Los Angeles (Coquillet, U.S.N.M.) ; Figueroa Peak, Station Barbara, N. F., June 2 (Hopping).

Nevada: Ormsby County, July 6 (Baker, I.U.).

\section{Anaspis duryi, new species}

(Pl. VII, Fig. 11)

TyPE.-From Leone Heights, California. A male, collected on September 7, 1908, by Charles Dury, to whom the species is dedicated; in the Museum of Zoology, University of Michigan (Liljeblad coll.).

Allotrpe.-A female, same data as type.

Paratypes.-Two, same data as type; five, Vancouver, British Columbia, May 10, 1931, and July 13, 1932; one, Grouse Mountains Trail, Vancouver, British Columbia, July 10; four, Salmon Arm, British Columbia, June and July; and one, Haslam Creek, Nanaimo, British Columbia, July 19, collected by H. B. Leach, taken on Betula occidentatis; in the collections of Charles Dury and H. B. Leach.

DESCRIPTION.-Subcuneate; head black, except near mouth parts, where it is ferruginous; antennae with four or six basal segments fusco-ferruginous; palpi ferruginous; thorax fusco-ferruginous ; elytra fusco-ferruginous, with a narrow basal cloud; female a little darker, finely covered with silky 
gray or white pubescence ; underside dark brown or nearly black; legs fuscoferruginous; femora nearly black in some females.

Head finely strigate, minutely aciculate and punctured; antennae long, with four or five segments reaching below thorax in male, a little shorter in female; third and fourth segments longest, fourth a little longer than third; fifth and sixth subequal in length, each one-fourth shorter than fourth; seventh to tenth each a little shorter than sixth and dilated at apex; last segment of the maxillary palpi cultriform; eyes somewhat coarsely granulated and emarginated behind antennae.

Pronotum nearly twice as broad as long; sides evenly rounded, widest at middle, slightly bisinuate at base; surface finely, transversely strigate, minutely aciculate and punctured.

Elytra at middle a little broader than thorax; apex rounded; surface finely, transversely strigate, more strongly on basal half and minutely punctured; underside minutely punctured; male with fifth abdominal segment triangularly cleft at apex and broadly excavated to base; from apex of third abdominal segment at middle extend two short movable appendages united at base and divergent to middle of fifth segment; these appendages rather broad, when viewed from side and oblique at tip; fourth abdominal segment slightly excavated at middle (when the appendages are pressed down to the segment they indicate a rather deep excavation) ; female with fifth abdominal segment normal and rounded at apex, with no appendages.

Length : $2.26-2.64 \mathrm{~mm}$.

REMARKs.-When viewed from above, this rather interesting species resembles the western variety of Anaspis rufa Say in color, but differs from it in the abdominal appendages of the male; rufa has four movable appendages that are very much separated at the apex and curved, whereas in this species there are only two, which are united at the base.

\section{Anaspis rufa Say \\ (Pl. VII, Fig. 14)}

Anaspis rufa Say, 1825, p. 244, Rocky Mountains; 1859, p. 309 . Leconte, 1862, p. 45.

J. B. Smith, 1882, pp. 77, 78. Schwarz, 1890, p. 76. Blatchley, 1910, p. 1310.

Anaspis filiformis Leconte, 1850, p. 231.

Anaspis nigriceps Leconte, 1862, p. 45.

Anaspis pallescens Mannerheim, 1843, p. 288.

Anaspis dimidiata Melsheimer, 1845, p. 312.

Anaspis ventralis Melsheimer, 1845, p. 312.

DESCRIPTION.-Head, thorax and elytra brownish yellow; antennae with four basal segments pale, fifth to eleventh black; underside pale, except abdomen, which is black or nearly so; legs pale.

Head. finely strigate and punctured; antennae long, nearly filiform; four apical segments reaching below thorax, seventh to tenth segments only 
slightly thickened; third and fourth segments longest, equal in length, each nearly as long as first and second segments combined; fifth and sixth equal in length, each one-fourth shorter than fourth; seventh to tenth equal in length, each about one-fourth shorter than sixth; last segment of maxillary palpi cultriform, rather long; eyes somewhat coarsely granulated and emarginated behind antennae.

Pronotum one-third broader than long, finely, transversely strigate and punctured; basal angles obtuse; basal lobe broadly rounded at middle in front of scutellum; scutellum triangular.

Elytra at middle a little broader than pronotum; finely, transversely strigate and punctured. Male with apex of third abdominal segment broadly emarginate at middle; from each side of this emargination extends a long, curved, movable appendage as long as fourth and fifth abdominal segments combined, sparsely covered with fine hairs; fourth abdominal segment is nearly evenly rounded at middle and at each side directly beneath the abovementioned appendage extends a narrower appendage, one-half as long as the fifth abdominal segment, slightly curved but a little broader toward apex, sparsely covered with fine hairs; fifth abdominal segment cleft to near middle and excavated from base to apex, excavated part wholly without pubescence; these appendages, lying in their normal condition, are closely pressed to the two last abdominal segments, forming an elevated ridge from apex of third segment to tip of fifth, and in this position it seems as if both segments are excavated at middle, but if these appendages are relaxed and raised it will be seen that only the fifth segment is hollowed out; female like male but without appendages, emargination or excavation of abdominal segments.

Length : $3-4 \mathrm{~mm}$.

REMARKs.-This species is rather common and sometimes is present in great numbers. I have collected hundreds at Pentwater, Michigan, on flowers of the red-stemmed dogwood ; Ralph Hopping has taken a great number on Pinus ponderosa at Midday Valley, British Columbia. The color varies a little, but aside from that, there are no divergencies. Some differences of opinion have appeared as to the position of the male appendages, as mentioned under the notes of the genus. I believe that $A$. rufa has two pairs of movable appendages, one pair long, extending from the apex of the third abdominal segment and another pair, shorter, starting from the fourth abdominal segment, and that the fifth segment is slightly cleft and excavated from base to apex. The type has not been examined by me.

Previous RECords.-Rocky Mountains (Say); central and western states, Canada and Sitka (Leconte) ; southern, central, and western states (Smith); Wallace and Gove counties, Kansas (Snow); Dome Rock, Platte Canyon, Colorado (Snow) ; Cincinnati, Ohio (Dury); Kosciusko, Fulton, Putnam, 
and Crawford counties, Indiana (Blatchley); Galinas Canyon, New Mexico (Snow); Charity Island, Michigan (Andrews).

Material eXamined.-British Columbia : Mount Robson, July 7 (Mason) ; Sinclair Creek, Banff, July 22 (Hopping) ; Lorna, August 5 (H. Richmond); Midday Valley, Merritt, July 19 to August 4 (Hopping) ; Boisdale, July 18 (A.M.N.H.) .

California : Maria County, May 15 (Nunenmacher) ; Tule River, July 2 (Daggett) ; San Diego, June 12 (Hubbs) ; Siberian Outpost, Tulare County, August 2 (Diven) ; Giant Forest, August 5 (Bradley); Tahoe, August 21 (Miss E. W. Mank) ; Santa Anna River, April 23 (Hart, I.U.).

Idaho : Fort Sherman, August (Merrill, U.S.N.M.).

Kansas: Douglas County, August (Tucker, K.U.) ; Decatur County (Williams, K.U.) ; Hodgeman County, July 17 (K.U.).

Maine: Monmouth and Paris, July 13 and 15 (Frost).

Maryland : Plummers Island, June 17 (McAtee, U.S.N.M.).

Massachusetts : Sudbury and Monterey, July 4 (Frost).

Michigan : Pentwater, July 20 (Liljeblad).

Montana: Glacier Park, July 18 (Miss E. W. Mank).

Newfoundland: Codroy, July (Gratacap, A.M.N.H.) ; Spruce Brook, July (A.M.N.H.).

New York: Ithaca, July 25, and Ringwood, July 24 (Dietrich).

Nova Scotia: Truro, July 4 (Matheson).

Ontario: Scotia Junction, July 27 (Wenzel).

Pennsylvania: Charter Oak and Cresses, July 10 and 21 (Kirk) ; Harrisburg, July 8 (Knull) ; Easton, May 30 (J. W. Green).

Washington: Easton (U.S.N.M.).

\section{SILARIA MULSANT}

Silaria Mulsant, 1856, pp. 39, 426.

DEschiption.-

Repli des élytres diminuant rapidement de largeur dès la base, nul ou presque nul au niveau du premier segment du ventre (Silaria Muls.).

Premier article des tarses postérieurs bien plus court que le tibia; $5^{\text {e }}$ segment ventral du ồ non fendu, échancré au bout, quelquefois caréné; espêces plus grandes souvent ornées de dessins de différentes couleurs sur les élytres. (Mulsant)

Epipleurae short and broad, only visible to first abdominal segment; first segment of posterior tarsi distinctly shorter than tibiae; fifth abdominal segment at apex indistinctly emarginated; species variable in color.

\section{Silaria revelstokei, new species}

Type.-From Revelstoke Mountain, British Columbia. A male, collected on July 16, 1925, by Mrs. Katherine Hopping; in the Canadian National collection at Ottawa. 
Allotype.-A female, same data as type; in the Canadian National collection.

PARATYPES.-Six males and two females, same data as type; in Canadian National collection and in the Museum of Zoology, University of Michigan (Liljeblad coll.).

DESCRIPTION.-Elongate; black, except basal three or four segments of antennae, palpi, and base of femora, which are more or less fusco-testaceous; pubescence sparse gray.

Head moderately large, with scarcely no visible neck, somewhat closely and deeply punctured; antennae reaching a little below base of thorax, eighth to eleventh segments gradually broadening; third segment longest; fourth to tenth segments nearly equal in length, each about one-fifth shorter than third; eleventh twice as long as tenth; last segment of maxillary palpi cultriform, rather broad near base, inner side very short; eyes large, deeply emarginated, not hairy.

Pronotum nearly twice as broad as long, broadest near base; sides rounded to apex; basal angles broadly rounded; surface transversely strigate and finely punctured; scutellum small, triangular.

Elytra five times as long as pronotum; sides nearly parallel, a little broader at middle in female; apex rounded and with distinct margin; epipleura visible to apex of first abdominal segment; surface transversely strigate, minutely punctured and with very slight indications of longitudinal ridges; anterior tarsi with third segment broad and bilobed, fourth segment very small; first segment of posterior tarsi one-fourth shorter than tibiae of same pair of legs; abdomen with five segments visible and without appendages ; fifth segment at apex in male deeply notched at middle, sides rounded and slightly concave from middle of notch to near base of segment; female with fifth segment rounded at tip.

Length : 2.5-3 mm.

REMARKs.-This species, when viewed from above, resembles Anaspis atrata Champion, but differs from that species by having a much shorter epipleural fold and no abdominal appendages visible-characters which Mulsant used for the separation of his subgenus Silaria from Anaspis. Therefore, I introduce revelstoke $i$ as the first Silaria recorded from North America.

\section{LARISIA EMERY}

Larisia Emery, 1876, p. 13.

\section{DESCRIPTION.-}

Repli des élytres diminuant rapidement de largeur dès la base, nul ou presque nul au niveau du premier segment du ventre. (Silaria Muls.).

Premier article des tarses postérieurs à peine plus court que le tibia; 5e segment ventral du $\hat{o}$ longitudinalement impressionné ou profondément fendu. Espèces trèspetites, ordinairement unicolores. (Emery) 
Epipleura short and broad, only visible to first abdominal segment; first segment of posterior tarsi scarcely as long as tibiae ; fifth abdominal segment at middle with a deeply emarginated impression; species uniformly colored.

\section{Larisia nigricolor, new species}

Trpe.-From Mount Robinson, Alberta, Canada. A male, collected July 20 ; in the Museum of Zoology, University of Michigan (Liljeblad coll.).

Allotype.-A female, same data as type.

Paratypes.-Forty specimens : two, Carbonate, Columbia River, British Columbia, elevation 2600 feet, July 7-12 (Bradley); ten, Beaver Creek, Montana, elevation 6300 feet, August (Hunter); one, Norris, Yellowstone Park (Bradford, A.M.N.H.) ; one, National Park, Wyoming, August; four, Pikes Peak, Colorado (Hubbard and Schwarz); seven, Ainsworth, British Columbia, July 10-11 (Currie, U.S.N.M.) ; three, Glacier Park, Montana, July 9 to August 18 (Miss E. W. Mank) ; two, East Spanish Peak, Huerfano County, Colorado, July 28, taken on skunk cabbage, elevation 8300 feet (Gaige) ; four, "off Lake, Ontario, Canada" (Brimley) ; one, Terrace, British Columbia (Mrs. Hippisley) ; four, Lorna, British Columbia, August 12 (C. Hopping); and one, Midday Valley, British Columbia, July 15 ( $\mathrm{R}$. Hopping); paratypes in collection of United States National Museum, American Museum of Natural History, Cornell University, University of Michigan, Kansas University, Mr. Brimley, Mrs. Hippisley, and Miss E. W. Mank.

Description.-Head black, mouth parts, four basal segments of antennae, and palpi rufo-testaceous; thorax, elytra, and underside entirely black; anterior and middle legs rufo-testaceous, posterior legs a little darker.

Head finely punctured, somewhat rugose; antennae a little longer than head and thorax, seventh to tenth segments much broadened at apex; first and second segments equal in size; third as long as first and second combined; fourth one-third shorter than third, fifth to tenth subequal in length, each one-fourth shorter than fourth; eleventh oval, longer than tenth; last segment of maxillary palpi triangular, with apical side longer than inner and somewhat sinuate; eyes emarginate behind antennae, finely granulated.

Pronotum twice as broad as long, very little broader than elytra at base; surface very finely, transversely strigate; hind angles obtuse; basal lobe at middle not very prominent, with a small, shallow dentation on each side; scutellum triangular, rather pointed at tip.

Elytra with sides nearly parallel to near apex, covered with very fine silky gray pubescence and finely, transversely strigate and finely punctured; epipleura reaching to first abdominal segment; abdominal segments at middle without appendages, but with long setae at middle; third segment at apex somewhat broadly emarginate at middle; fourth segment with less 
broad emargination; fifth segment ovally cleft to near base, appearing excavated at middle. At the side of the aedeagus are seen two long needle-like appendages a little longer than fifth abdominal segment; these appendages cannot be seen unless the sexual organ is extruded. Posterior tibiae with two long, pale spurs, outer one extending to middle of first segment of posterior tarsi, inner one a little shorter; first segment of posterior tarsi about as long as tibiae; abdominal segment not visible from above. Female very much like male, but the abdominal segment lacks the setae at middle and the last segment of the abdomen is visible from above.

Length : $2.5 \mathrm{~mm}$.

Remarks.-This species to some extent resembles Anaspis nigrina Csiki (nec nigra Haldeman) and has been placed with it in collections on account of its dark color and because its thorax is twice as broad as long. The male, however, does not possess any movable appendages on the third abdominal segment and cannot, therefore, be placed in the genus Anaspis. This genus has been subdivided by Emery, and the specimens of the present species agree very well with the Emery subgenus Larisia (here recognized as a full genus), which has not been previously recorded from North America.

\section{NASSIPA EMERY}

Nassipa Emery, 1876, p. 13.

\section{Description.-}

Repli des élytres diminuant insensiblement de largeur de la base à l'extrémité; encore bien visible au niveau du premier segment du ventre (Anaspis Muls.).

Antennes moniliformes ou submoniliformes, leurs articles 6-10 subégaux. (Emery)

Epipleura long, visible to the third abdominal segments, or longer; antennae moniliform or submoniliform; sixth to tenth segments subequal in length.

\section{Nassipa hoppingi, new species}

Type.-From Midday Valley, British Columbia. A male, collected July 20, 1923, by Ralph Hopping ; in the Canadian National collection at Ottawa.

Allotrpe.-A female, type locality, collected July 22, 1923, by Ralph Hopping; in the Canadian National collection.

Paratypes.-Three males and five females: six, Midday Valley, British Columbia, collected July 6 to August 7, 1923, by Ralph Hopping; two, same locality, July 12 and 18, 1925, collected by William Mathers; one, same locality, June 14, 1925, collected by J. Stanley; and one, Midday Creek, Indian Meadows, British Columbia, July 13, 1920, collected by Ralph Hopping; all taken on Pinus ponderosa; paratypes in the Museum of Zoology, University of Michigan (Liljeblad coll.).

Description.-Elongate, nearly parallel; head nearly black, except in front of antennae, where it is yellow testaceous, basal segments of antennae 
yellow testaceous, three or four apical segments more or less black; palpi testaceous; eyes black; thorax yellow testaceous, with a black spot or cloud on each side, these spots in some specimens so extended as to cover entire apical half of thorax; scutellum testaceous or fusco-testaceous; elytra testaceous, with a sutural scutellar cloud, which appears variable, in some specimens covering more than half of elytra in width from base to near apex, whereas in others it constitutes only a long, triangular, black cloud or spot near base; undersurface black; legs testaceous, with femora somewhat cloudy; surface with fine yellowish pubescence.

Head about one-half as broad as thorax, surface finely strigate; antennae long, reaching a little below base of thorax, fifth to tenth segments submoniliform, gradually increasing in width; third and fourth segments each a little longer than fifth; last segment of maxillary palpi triangular, with inner side slightly shorter than apical; last segment of labial palpi a little longer than broad, broadest at apex and emarginate, with sides bent slightly downward; eyes rather coarsely granulated and with a deep emargination behind antennae.

Pronotum twice as broad as long, a little broader than elytra at base; sides rounded; basal angles nearly acute; surface finely strigate and aciculate; scutellum triangular, rounded at apex.

Elytra broadest at middle, slightly tapering to rounded apex; surface transversely strigate and finely punctured; epipleura long and narrow, distinctly visible to third abdominal segment; abdomen with five visible segments and without appendages; fifth segment in male slightly concave at middle and at tip somewhat triangularly notched or emarginate, in female rounded; posterior tibiae shorter than first and second tarsal segments combined; fourth segment of anterior and middle tarsi very small, scarcely visible.

Length : 2.5-2.75 $\mathrm{mm}$.

REMARKs.-This species in form, as well as in many other characters, resembles several of our Anaspis, but it cannot be associated with that genus, for it does not possess any abdominal appendages. It agrees so closely, however, with the genus Nassipa of Emery, that I do not find it necessary to erect a new genus.

The color pattern of the elytra is extremely variable. In the male and female types the black scutellar, sutural stripe is rather broad and nearly parallel to near the apex, but in some other specimens it differs, consisting only of a short scutellar dash, broadest near the base and scarcely reaching the middle of the elytra. 
Bach, Michael

\section{BIBLIOGRAPHY}

1856 Nächtrage und Verbesserungen zur Käferfauna von Nord- und Mittel-Deutschland. Stett. Ent. Zeit., 17: 241-47.

BLATCHLEY, WiLLis $\mathrm{S}$.

1910 On the Coleoptera Known to Occur in Indiana. Ind. Dept. Geol. and Nat. Res., Bull., 1: 1-1386.

Böving, AdaM G.

1929 On Classification of Beetles According to Larval Characters. Bull. Brk. Ent. Soc., 24: 55-80.

Casey, Thomas L.

1884-85 Contributions to the Deseriptive and Systematic Coleopterology of North America. Philadelphia: Collins. 2 pts. 198 pp.

Champion, George C.

1891 Coleoptera. Biologia Centrali-Americana, 4, 2, 1-494, 5 pls.

1896 On the Heteromerous Coleoptera of St. Vincent, Grenada, and the Grenadines. Trans. Ent. Soc. London, pp. 1-54, Pl. I.

Costa, AchiLle

1854 Mordellidea. Fauna dell Regno di Napoli. 32 pp., 6 col. pls.

Csiki, E.

1915 Mordellidae. In Coleopterorum Catalogus. Berlin: W. Junk. Pars 63: 1-84. Dury, Charles

1906 Ecological Notes on Some Coleoptera of the Cincinnati Region, Including Seven New Species. Journ. Cincinnati Soc. Nat. Hist., 20 : 251-56.

EMERY, C.

1876 Mordellidae (essai monographique). L'Abeille, 14: 1-128.

FABRicius, Johann C.

1775 Systema entomologiae. . . Flensburg and Lipsiae: Officina Libraria Kortii. Pp. $30+832$.

1792-94 Entomologica systematica. . . Hafniae: C. G. Proft. 4 vols.

1798 Supplementum entomologiae systematicae. Hafniae: Proft and Storch.

1801 Systema eleutheratorum. . . Kiliae: Bibliopolii Acad. Novi. 2 vols.

Fall, Henry C.

1907 [Descriptions.] In The Coleoptera of New Mexico, by Cockerell and Fall. Trans. Amer. Ent. Soc., 33: 145-272.

Frost, C. A.

1913 Notes on Tomoxia bidentata Say and lineella Lec. Ent. News, 45: 126-29. GEOFFroy, ÉTIENNE L.

1762 Histoire abrégée des insectes qui se trouvent aux environs de Paris, dans laquelle ces animaux sont rangés suivant un ordre méthodique. Paris: Durand. 2 vols.

Germar, ERnst F.

1824 Insectorum species novae aut minus cognitae, descriptionibus illustratae. Halae: J. C. Hendelii et filii. Pp. 1-624, 2 pl.

GYLLENHAL, LEONHARD

1827 Insecta Suecica descripta. Scaris: F. J. Leverentz. 4: 1-760.

Haldeman, Samuer S.

1848 Descriptions of North American Coleoptera, Chiefly in the Cabinet of J. L. Leconte, with References to Described Species. Journ. Acad. Nat. Sci. Phila., (2) 1: 95-110. 
Helmuth, C. A.

1864 New Species of Mordellistena Collected in Illinois. Proc. Acad. Nat. Sci. Phila., 16: 105.

1865 New Species of Mordellidae Collected in Illinois. Ibid., 17: 96.

LECONTE, JoHN L.

1850 General Remarks upon the Coleoptera of Lake Superior. In Louis Agassiz, Lake Superior. . . . Boston: Gould, Kendall, and Lincoln. 4: 201-42.

1854 Some Corrections in Nomenclature. Proc. Acad. Nat. Sci. Phila., pp. 216-20.

1858 Descriptions of New Species of Coleoptera, Chiefly Collected by the U. S. and Mexican Boundary Commission under Major W. Emory. Ibid., pp. 59-89.

1859 The Coleoptera of Kansas and Eastern New Mexico. Smithson. Contrib. Knowl., 11: 1-58.

1862 Synopsis of the Mordellidae of the United States. Proc. Acad. Nat. Sci. Phila., 14: 43-51.

Leconte, JoHn L., and E. A. Schwarz

1878 Coleoptera of Florida. Proc. Amer. Phil. Soc., 17: 353-472.

Leng, Charles W.

1920 Catalogue of the Coleoptera of America, North of Mexico. Mount Vernon, N. Y.: John D. Sherman, Jr. Pp. $x+470$.

Leng, Charles W., and Andrew J. Mutchler

1927 Supplement (1919-1924) to the Catalogue of the Coleoptera of America, North of Mexico. Mount Vernon, N. Y.: John D. Sherman, Jr. Pp. 78.

LiLJEBLAd, EMIL

1917 New Species of Coleoptera of the Genus Mordellistena. Can. Ent., 49: 9-13.

1918 Descriptions of Eight New Species of the Family Mordellidae. Ibid., 50: 153-58.

1921 Notes on Mordellidae, with Descriptions of New Species. Ibid., 53: 181-86.

1922 A Revision of the Species of Mordella Related to Mordella melaena. Ibid., $54: 51-58$.

LiNell, MaRtin J.

1887 Notes on Some Coleoptera. Ent. Amer., 3: 171.

LINNE, CARL VON

1758-59 Systema naturae. ... 10th ed.; Holmiae: L. Salvii. 2 vols.

Mannerheim, Carl G.

1843 Beitrag zur Käferfauna der Aleutischen Inseln, der Insel Sitka und NeuCalifornien. Bull. Moscou, 16: 175-314.

Melsheimer, Friedrich E.

1846 Descriptions of New Species of Coleoptera of the U. S. Proc. Acad. Nat. Sci. Phila., 2: 26-43, 98-118, 134-60, 213-23, 302-18; 3: 53-66, 158-81.

Mequignon, A.

1937 Observations sur quelques noms de genre. II. Synonymies proposées par Embrik Strand. Bull. Soc. Ent. Fr., 42: 276-79.

MULSANI?, ETIENNE

1856 Histoire des Coléoptères de France (Barbipalpes, Longipèdes, Latipennes et Latigènes). Ann. Soc. Linn. Lyon, n. s., 3: 193-522.

MULSANT, ETIENNE AND REY

1858 Description d'une espèce constitutant un genre nouveau dans la famille des Mordelliens. Ann. Soc. Agr. Lyon, ser. 3, 2: 313-15.

PaCKard, Alpheus S.

1883 Report. Bull. U. S. Geol. Surv., 3: 168, Fig. 9. 
Paykull, Gustaf von

1800 Fauna Suecica. Insecta. . . U Upsala: J. F. Edman. 3: 1-459. Rossi, Pietro

1792-94 Mantissa insectorum, exhibiens species naper in Etruria collectas, adjectis faunae Etruscae illustrationibus ac emendationibus. Pisa: Giovanelli. Pp. $148+154,8$ col. pl.

SAY, THOMAS

1823-24 Descriptions of Coleopterous Insects Collected in the Late Expedition to the Rocky Mountains. Journ. Acad. Nat. Sci. Phila., 3: 139-216, 238-82, 298331, 403-62; 4: 83-99.

1824 American Entomology, or Descriptions of the Insects of North America. ... Philadelphia: S. A. Mitchell. 3 vols.

1835 Descriptions of North American Coleopterous Insects and Observations on Some Already Described. Boston Journ., 1, 2 : 151-203.

1859 The Complete Writings of Thomas Say on the Entomology of North America, Ed. by John L. Le Conte, with a Memoir of the Author by George Ord. New York: Baillière Bros. 2 vols.

SCHILSKY, JULIUS

1895 Die Käfer Europa's; nach der Natur beschrieben. Nürnberg: Bauer and Raspe. (In Küster, Kraatz, and Schilsky.) Hft. 31.

1899 Die Käfer Europa's; nach der Natur beschrieben. Nürnberg: Bauer and Raspe. (In Küster, Kraatz, and Schilsky.) Hft. 36.

Schwarz, Eugene A.

1890 Coleoptera Common to N. A. and Other Lands. Proc. Ent. Soc. Wash., 1: 182-94.

SHARP, DAVID

1901 Insects. In Cambridge Natural History. London and New York: Macmillan

SMITH, JоHN B.

Co. 6: 268, Fig. 139, a-d.

1882 A Synopsis of the Mordellidae of the United States. Trans. Amer. Ent. Soc., 10: 73-100, Pls. I-III.

$1883 a$ New Mordellidae and Notes. Bull. Brk. Ent. Soc., 5: 80-81.

$1183 b$ Mordellidae, Notes and Descriptions. Ibid., 6: 3-5.

STRAND, EMBRIK

1929 Zoological Nomenclatorial Notes. Acta Univ. Latviensis, 20: 1-29.

STURM, JACOB

1843 Catalog der Käfersammlung. Catalog de meiner Insekten Sammlung. 2d ed.; Nürnberg: Kosten des Verfassers. Pp. $12+386,6$ col. pl.

Trost, Patriz

1801 Kleiner Beytrag zur Entomologie in einem Verzeichnisse der Eichstettischen bekannten und neuendeckten Insecten mit Anmerkungen für kenner und Liebhaber, Pt. 1. 71 pp. 
PLATES 


\section{PLATE I}

FIG. 1. Position of the carinated ridges on the posterior legs in the subfamily Mordellini.
a. Glipodes.
b. Conalia.
c. Isotrilophus.
d. Glipa and Mordella.
e. Tomoxia.
f. Mordellistena.

FIG. 2. Glipodes sericans Melsheimer, male.
a. Antennae of male.
b. Maxillary palpi of male.
c. Posterior leg.

Fig. 3. Conalia helva Leconte.
a. Antennae of male.
b. Maxillary palpi of male.
c. Posterior leg.

FIG. 4. Isotrilophus erratica Smith, male.
a. Antennae of male.
b. Maxillary palpi of male.
c. Posterior leg.

FIG. 5. Glipa hilaris Say, male.
a. Antennae of male.
b. Maxillary palpi of male.
c. Posterior leg.
d. Mesosternum.

FIG. 6. Glipa oculata Say.
a. Antennae of male.
b. Maxillary palpi of male and female.
c. Scutellum.
d. Mesosternum of male.

FIG. 7. Glipa octopunctata Fabricius.
a. Antennae of male.
b. Maxillary palpi of male.
c. Scutellum.
d. Mesosternum of male and female.

Fig. 8. Glipa bidentata Say.
a. Antennae of male.
b. Maxillary palpi of male.
c. Posterior leg.
d. Mesosternum.
e. Seutellum. 
PLATE I

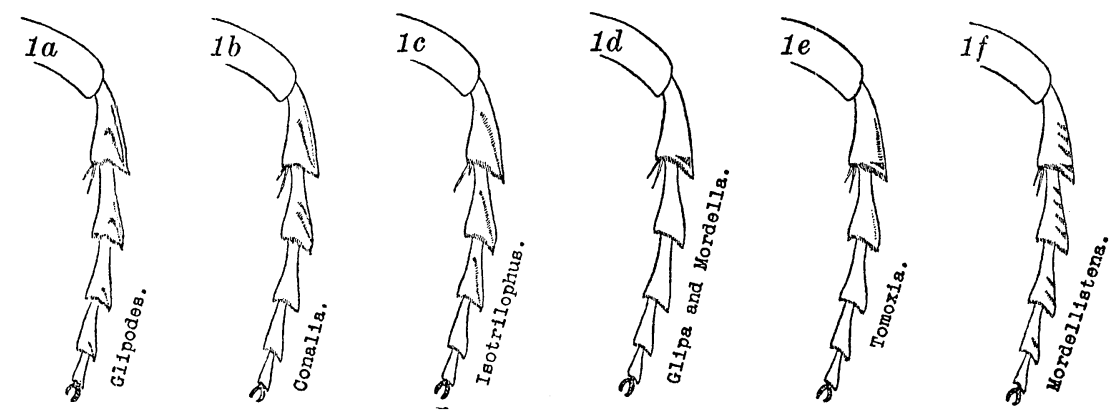

Fig. $\overline{1}$

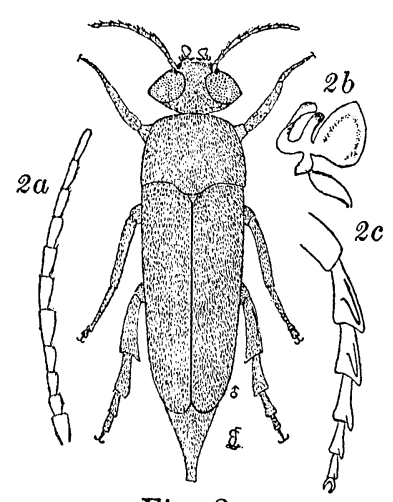

Fig. 2

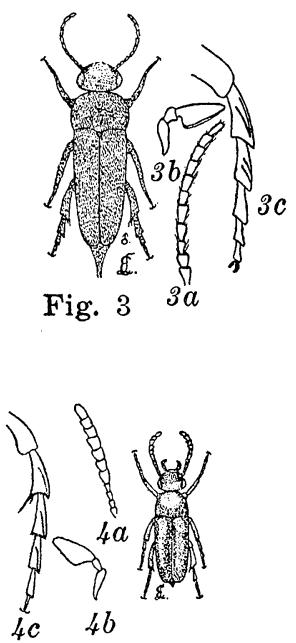

Fig. 4

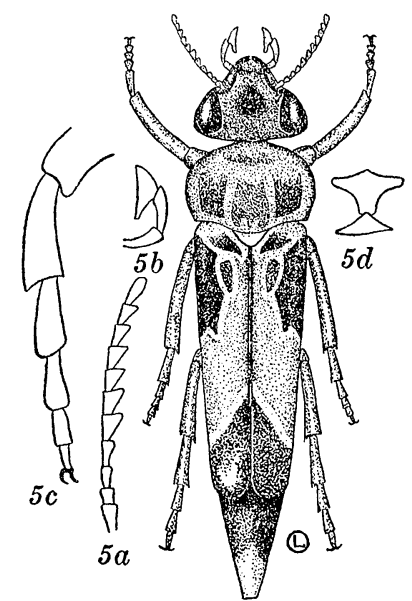

Fig. 5

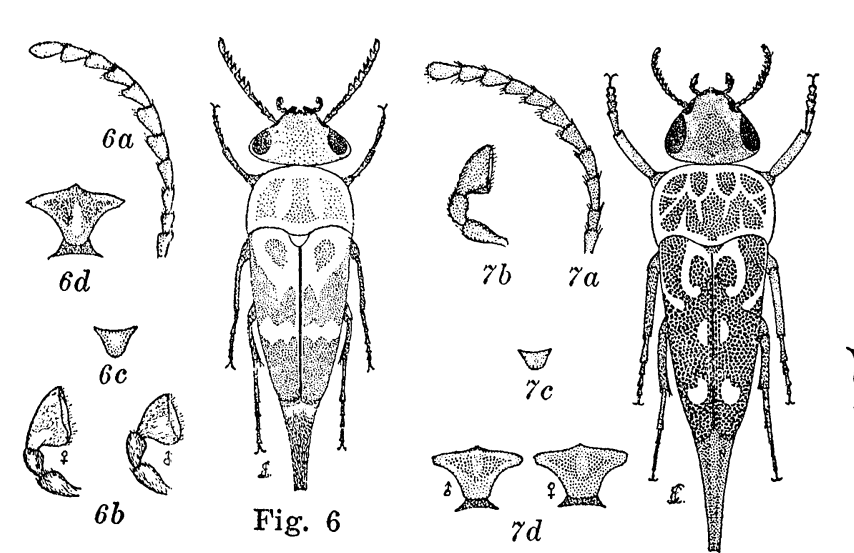

Fig. 7

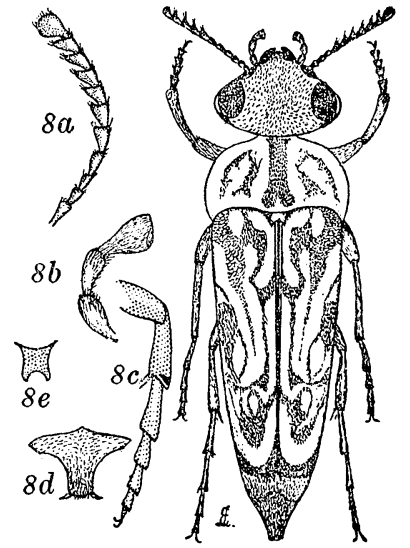

Fig. 8 


\section{PLATE II}

FIG. 1. Glipa inflammata Leconte.
a. Antennae of male.
b. Maxillary palpi of male.
c. Scutellum.
d. Mesosternum of male.

Fic. 2. Glipa perlineata Fall.

a. Antennae of male.

$b$. Maxillary palpi of male.

FIG. 3. Mordella knulli Liljeblad.
a. Antennae.
b. Maxillary palpi.
c. Scutellum.

FIG. 4. Mordella signata Champion.
a. Antennae.
b. Maxillary palpi.

Fig. 5. Mordella schwarzi, new species.
a. Antennae.
b. Maxillary palpi.

FIG. 6. Mordella quadripunctata Say.
a. Antennae of male.
b. Maxillary palpi of male.

Fig. 7. Mordella lunulata Helmuth.
a. Antennae of male.
b. Maxillary palpi of male.
c. Mesosternum of male and female.

Fig. 8. Mordella obliqua Leconte.
a. Antennae of male.
b. Maxillary palpi of male.
c. Scutellum.

FIG. 9. Mordella melaena Germar.
a. Antennae of male.
b. Maxillary palpi of male.
c. Mesosternum of male.
d. Scutellum.

FIG. 10. Mordella brevistylis Liljeblad.
a. Antennae of male.
b. Maxillary palpi of male.
c. Scutellum. 
PLATE II

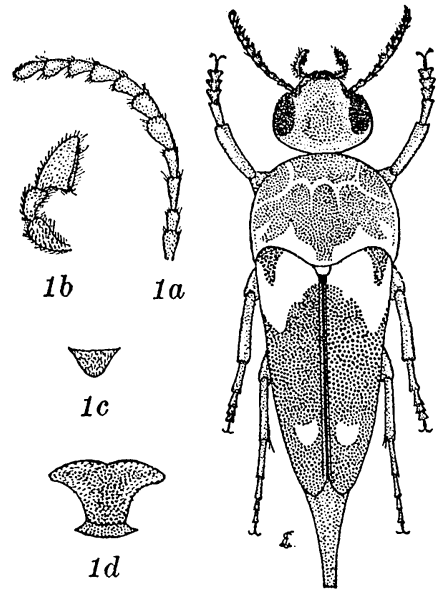

Fig. 1

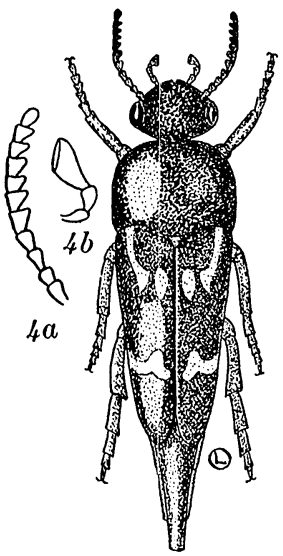

Fig. 4

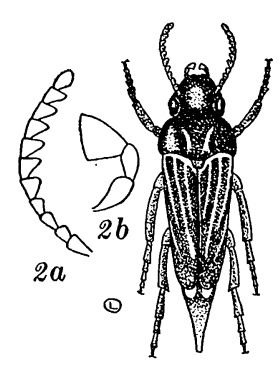

Fig. 2
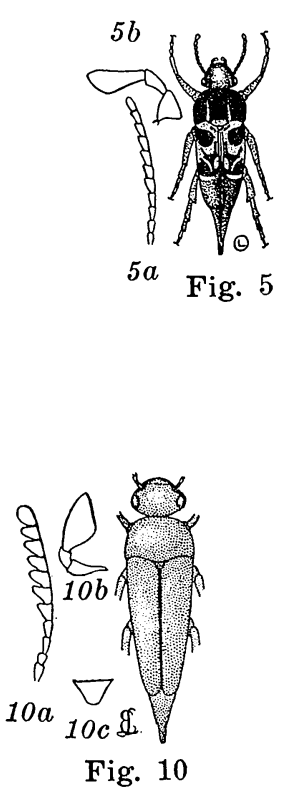

Fig. 10

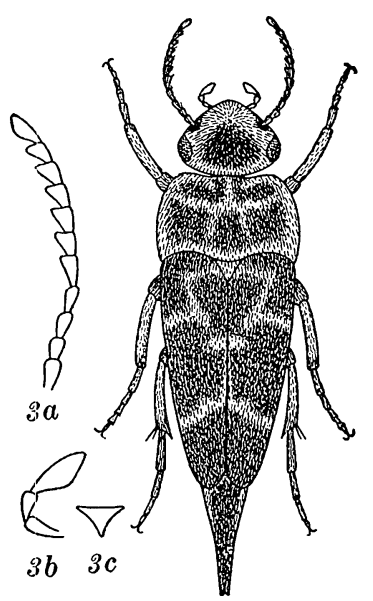

Fig. 3

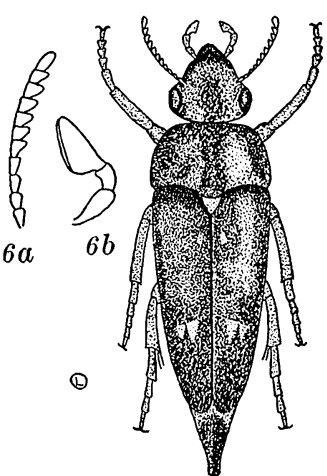

Fig. 6
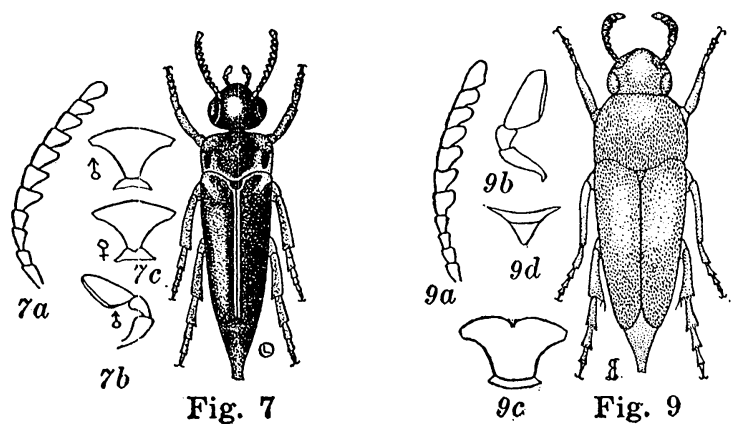

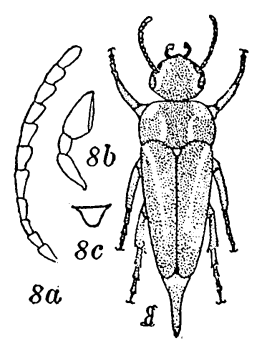

Fig. 8 


\section{PLATE III}

FIG. 1. Tomoxia serval Say.

b. Maxillary palpi of male.

a. Antennae of male.

c. Posterior leg.

b. Maxillary palpi of male.

d. Scutellum.

c. Posterior leg.

d. Scutellum.

e. Mesosternum of male.

Frg. 2. Mordella insulata Leconte.

e. Mesosternum of male and female

FIG. 14. Tomoxia borealis Leconte.

a. Antennae of male.

b. Maxillary palpi of male and female.

c. Scutellum.

d. Mesosternum of male.

a. Antennae of male.

b. Maxillary palpi of male.

c. Posterior leg.

d. Scutellum.

e. Mesosternum of male.

FIG. 3. Mordella marginata Melsheimer.

a. Antennae of male.

b. Maxillary palpi of male and female.

FIG. 4. Mordella marginata Melsheimer.

Fig. 5. Mordella cinereoatra, new species.

a. Maxillary palpi of male.

FIG. 6. Mordella atrata Melsheimer.

a. Antennae of male.

b. Maxillary palpi of male.

c. Maxillary palpi of female.

d. Scutellum.

Fig. 7. Mordella angulata Leconte.

FrG. 8. Mordella deserta Casey, elytra.

FIG. 15. Tomoxia fascifera Leconte.

a. Antennae of male.

b. Maxillary palpi of male.

FIG. 16. Tomoxia lineella Leconte.

a. Antennae of male.

b. Maxillary palpi of male.

c. Posterior leg.

d. Scutellum.

e. Mesosternum of male.

FIg. 17. Tomoxia undulata Melsheimer.

a. Antennae of male.

b. Maxillary palpi of male.

c. Posterior leg.

d. Scutellum.

$e$. Mesosternum of male.

FIG. 9. Mordella albosuturalis Liljeblad. FIG. 18. Tomoxia discoidea Melsheimer.

a. Antennae of male.

a. Antennae of male.

b. Maxillary palpi of male.

c. Maxillary palpi of female.

d. Scutellum.

b. Maxillary palpi of male and female.

c. Posterior leg.

d. Scutellum.

$e$. Mesosternum of male.

FIG. 10. Mordella hubbsi Liljeblad.

a. Antennae of male.

b. Maxillary palpi of male.

c. Maxillary palpi of female.

d. Scutellum.

Fig. 11. Mordella grandis Liljeblad.

a. Antennae of male.

b. Maxillary palpi of male.

c. Maxillary palpi of female.

d. Scutellum.

Tomoxia triloba Say.

a. Antennae of male.

b. Maxillary palpi of male and female.

c. Posterior leg.

d. Scutellum.

e. Mesosternum of male.

FIG. 12. Mordella invisitata, new species.

FIG. 20. Tomoxia carinata Smith.

a. Antennae of male.

b. Maxillary palpi of male.

a. Antennae of male.

b. Maxillary palpi of male.

c. Posterior leg.

d. Scutellum.

e. Mesosternum.

a. Antennae of male. 


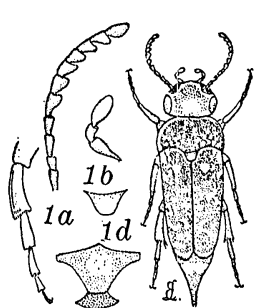

1c 1e Fig. 1

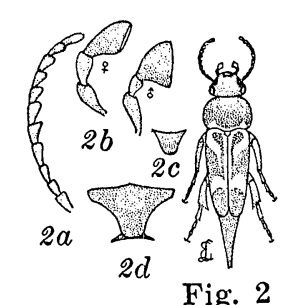

Fig. 2

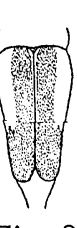

Fig. 8

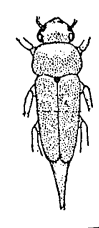

Fig. 7

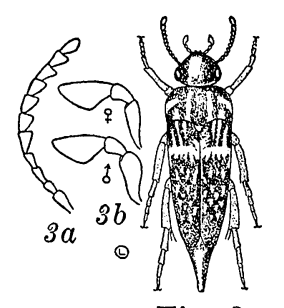

Fig. 3

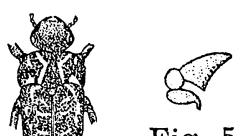

Fig. 5

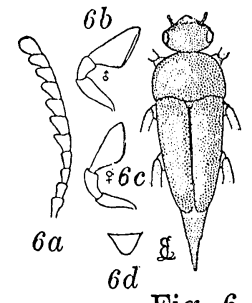

Fig. 6

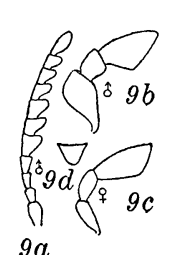

Fig. 9

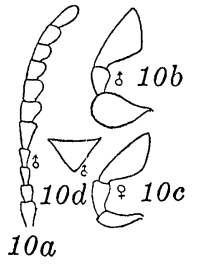

Fig. 10

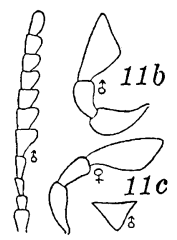

11a 11d

Fig. 11

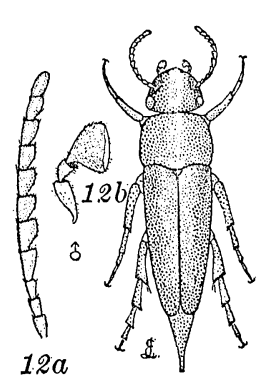

Fig. 12
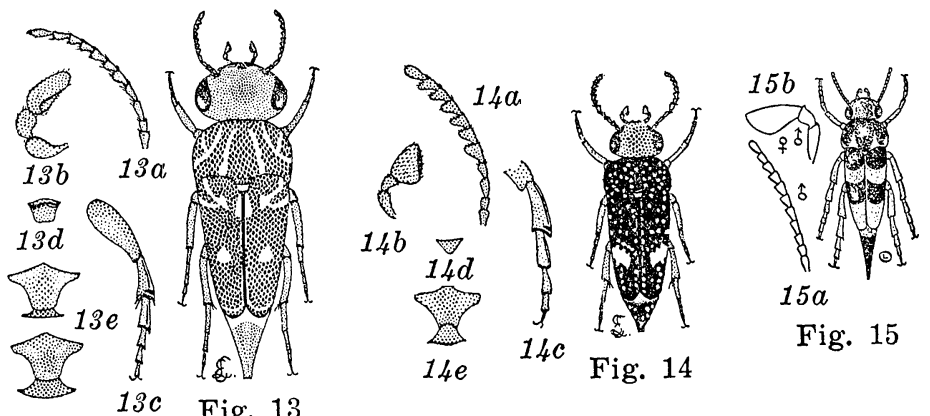

Fig. 15
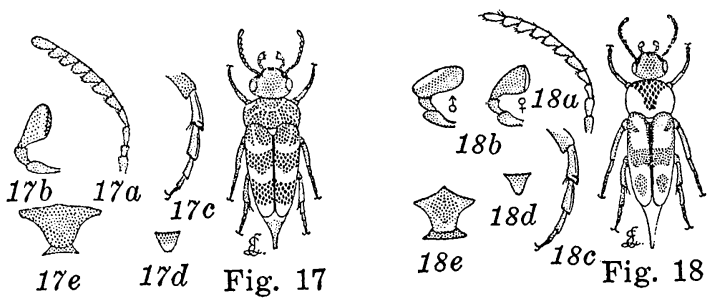

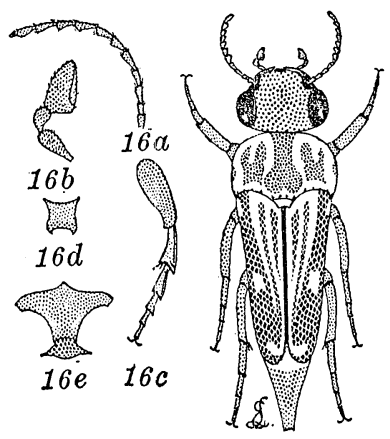

Fig. 16
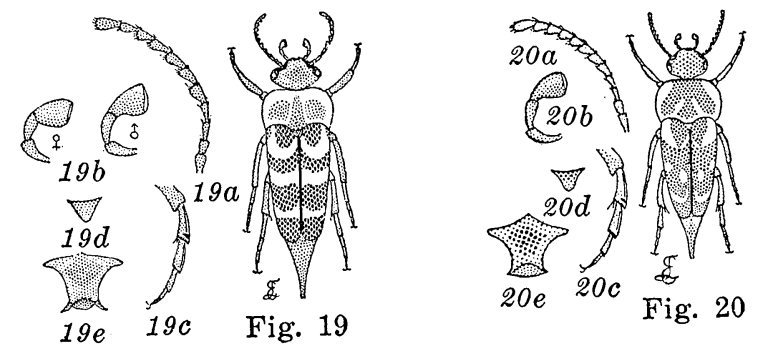


\section{PLATE IV}

Frg. 1. Mordellistena frosti Liljeblad.

a. Antennae of male.

b. Maxillary palpi of male.

c. Posterior leg.

FIG. 2. Mordellistena arida Leconte.
a. Antennae of male.
b. Maxillary palpi of male.
c. Maxillary palpi of female.
d. Posterior leg.

FIG. 3. Mordellistena bicinctella Leconte.
a. Antennae of male.
b. Maxillary palpi of male and female.
c. Posterior leg.

FIG. 4. Mordellistena tarsalis Smith, elytra.
a. Posterior leg.

FIg. 5. Mordellistena vilis Leconte.
a. Antennae of male.
b. Maxillary palpi of male.

FIg. 6. Mordellistena pauxilla new species.

a. Antennae of male.

b. Maxillary palpi of male.

Fig. 7. Mordellistena vapida Leconte.

a. Antennae of male.

$b$. Maxillary palpi of male.

FIG. 8. Mordellistena intermixta Helmuth.
a. Antennae of male.
$b$. Maxillary palpi of male.

Fig. 9. Mordellistena trifasciata Say.
a. Antennae of male.
b. Maxillary palpi of male.
c. Posterior leg.

FIG. 10. Mordellistena sexnotata Dury.

FIG. 11. Mordellistena scapularis Say.
a. Antennae of male.
b. Maxillary palpi of female.
c. Maxillary palpi of male.
d. Posterior leg.

Frg. 12. Mordellistena limbalis Melsheimer. a. Antennae of male. b. Maxillary palpi of male.

c. Maxillary palpi of female.

d. Posterior leg.

FIG. 13. Mordellistena dimidiata Helmuth.

a. Antennae of male.

b. Maxillary palpi of male.

c. Maxillary palpi of female.

FIG. 14. Mordellistena nebulosa, new species.

a. Antennae of male.

b. Maxillary palpi of male.

FIG. 15. Mordellistena ornata Melsheimer.

a. Antennae of male.

b. Maxillary palpi of male.

c. Maxillary palpi of female.

FIG. 16. Mordellistena argenteola, new species.

Frg. 17. Mordellistena syntaenia Liljeblad.

FrG. 18. Mordellistena egregia, new species.

a. Antennae of male.

b. Maxillary palpi of male.

Fig. 19. Mordellistena comata Leconte.

a. Antennae of male.

$b$. Maxillary palpi of male.

c. Posterior leg.

Frg. 20. Mordellistena cervicalis Leconte.

a. Antennae of male.

b. Maxillary palpi of male.

c. Maxillary palpi of female.

FIG. 21. Mordellistena aspersa Melsheimer.

a. Antennae of male.

b. Maxillary palpi of male.

Fig. 22. Mordellistena rufilabris, new species.

a. Antennae of male.

b. Maxillary palpi of male.

Fig. 23. Mordellistena rubrilabris Helmuth.

a. Antennae of male.

b. Maxillary palpi of male.

Fig. 24. Mordellistena pullata, new species.

a. Antennae of male.

b. Maxillary palpi. 


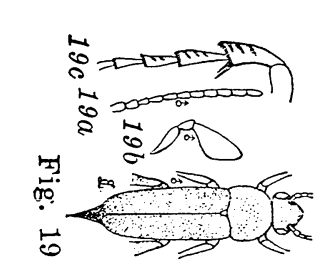

응 500000000000

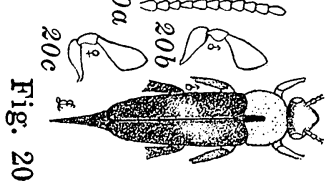

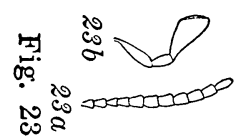

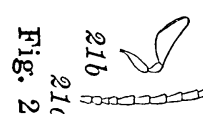

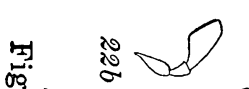

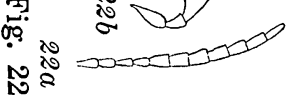

कृ की

का

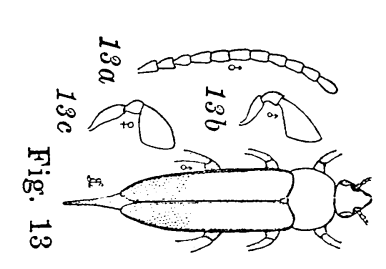

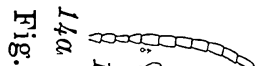

活 会/

ثै

蛋

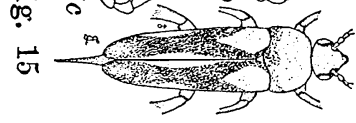

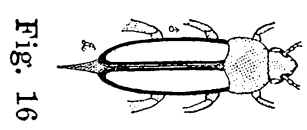

穴

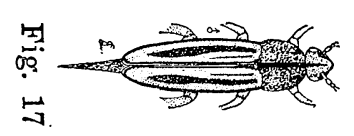

牙岕

i $\infty$
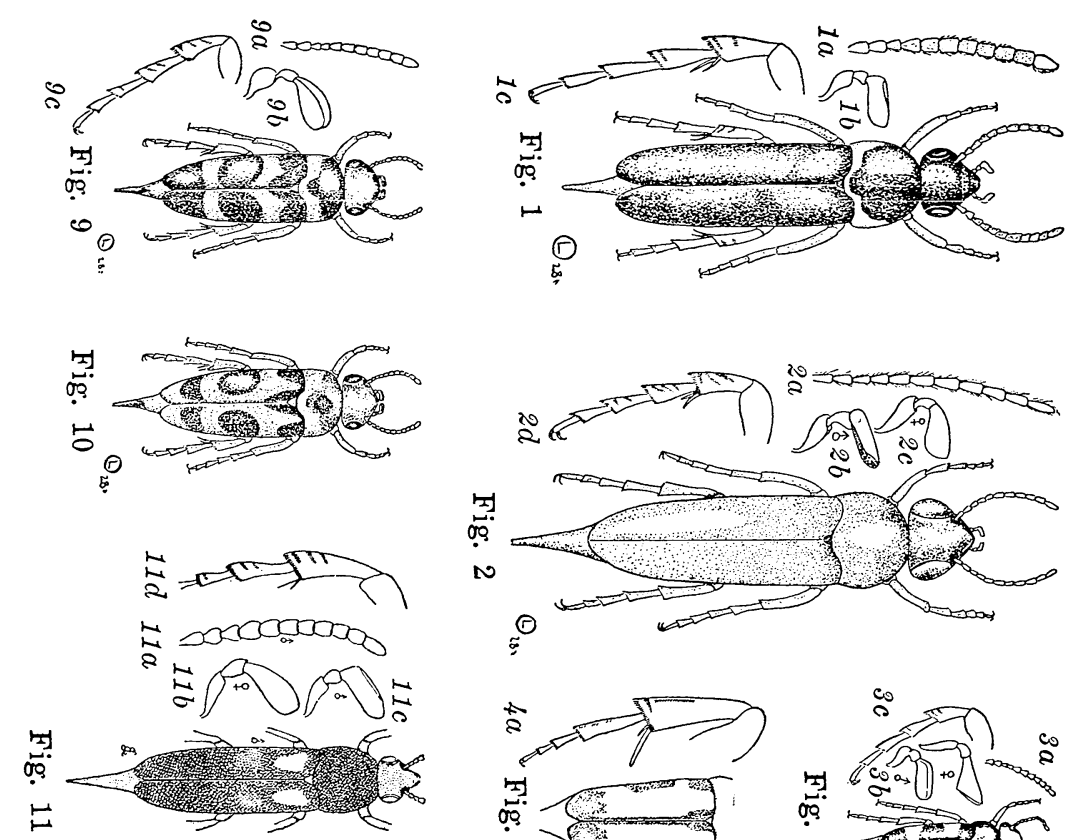

है $=\mathrm{W}$

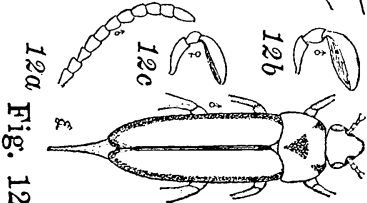

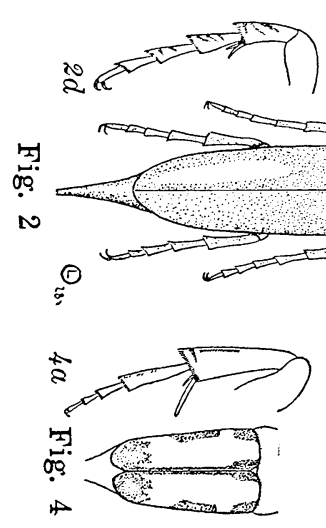

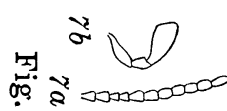

$\checkmark$

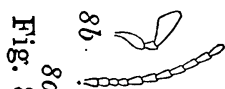

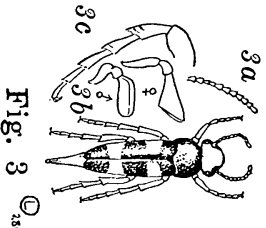

为 or 0200000000

or gr

身 


\section{PLATE V}

FIG. 1. Mordellistena minuta Smith.
a. Antennae of male.
b. Maxillary palpi of male.

c. Posterior leg.

Fig. 2. Mordellistena picilabris Helmuth.

a. Antennae of male.

b. Maxillary palpi of male.

FIG. 3. Mordellistena minutalis, new species.

a. Antennae of male.

b. Maxillary palpi of male.

Fig. 4. Mordellistena infima Leconte.

a. Antennae of male.

b. Maxillary palpi of male.

c. Posterior leg.

FIG. 5. Mordellistena andreae var. andreae Leconte, male.

a. Maxillary palpi of male and female.

b. Posterior leg.

FIG. 6. Mordellistena andreae var. andreae Leconte, female.

FIG. 7. Mordellistena andreae var. ancilla Leconte, male.

Frg. 8. Mordellistena andreae var. ancilla Leconte, female.

FIG. 9. Mordellistena andreae var. ustulata Leconte.

FIG. 10. Mordellistena semiusta Leconte.

a. Antennae of male.

b. Maxillary palpi of male.

Fig. 11. Mordellistena guttulata Helmuth.

a. Antennae of male.

b. Maxillary palpi of male.

FIG. 12. Mordellistena nigricans Melsheimer.

a. Antennae of male.

b. Maxillary palpi of male.

FIg. 13. Mordellistena parva, new species.

a. Antennae of male.

$b$. Maxillary palpi of male.

FIG. 14. Mordellistena subfucus, new species.

a. Antennae of male.

b. Maxillary palpi of male.
Fig. 15. Mordellistena wickhami, new species.

a. Antennae of male.

b. Maxillary palpi of male.

FIG. 16. Mordellistena ruficeps Leconte.

a. Antennae of male.

b. Maxillary palpi of male.

FIG. 17. Mordellistena floridensis Smith.

a. Antennae of male.

b. Maxillary palpi of male.

Fig. 18. Mordellistena blandula, new species.

a. Antennae of male.

b. Maxillary palpi of male.

Fig. 19. Mordellistena tantula, new species.

a. Antennae of male.

b. Maxillary palpi of male.

Frg. 20. Mordellistena ambusta Leconte.

a. Antennae of male.

b. Maxillary palpi of male.

FIG. 21. Mordellistena nunenmacheri Liljeblad.

a. Antennae of male.

b. Maxillary palpi of male.

FIG. 22. Mordellistena pustulata Melsheimer.

FIG. 23. Mordellistena convicta Leconte.

FIG. 24. Mordellistena discolor Melsheimer.

a. Antennae of male.

$b$. Maxillary palpi of male.

FIG. 25. Mordellistena bihamata Melsheimer.

a. Antennae of male.

b. Maxillary palpi of male.

c. Maxillary palpi of female.

FIG. 26. Mordellistena pubescens Fabricius.

a. Antennae of male.

b. Maxillary palpi of male.

Frg. 27. Mordellistena hebraica Leconte.

a. Antennae of male.

$b$. Maxillary palpi of male.

FIG. 28. Mordellistena liturata Melsheimer.

a. Antennae of male.

b. Maxillary palpi of male.

c. Maxillary palpi of female.

FIG. 29. Mordellistena pulchra Liljeblad, male FIG. 30. Mordellistena pulchra Liljeblad, female 

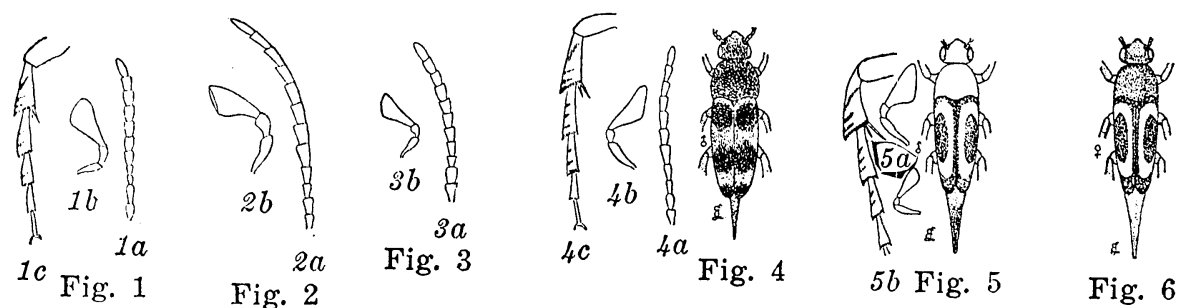

Fig. 4

56 Fig. 5

Fig. 6

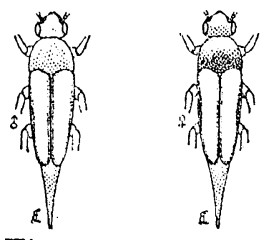

Fig. 7 Fig. 8

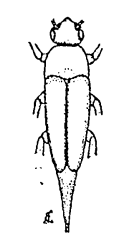

Fig. 9

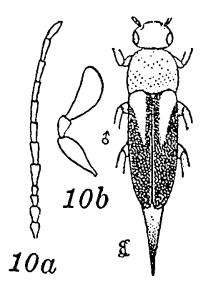

Fig. 10

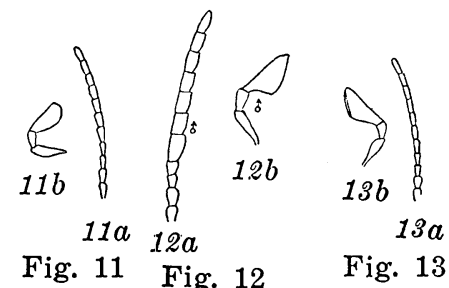

Fig. 11 Fig. 12 Fig. 13

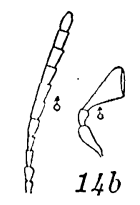

14a Fig. 14

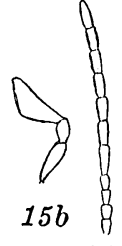

$15 a$
ig. 15

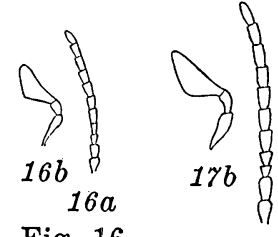

$17 a$
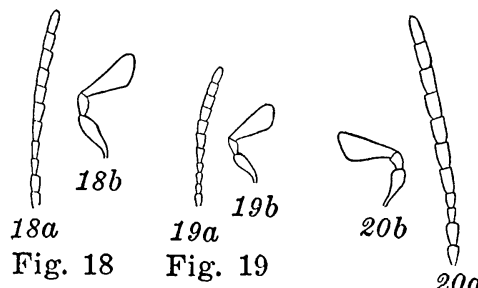

$20 a$

Fig. 20

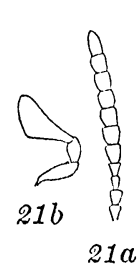

Fig. 21

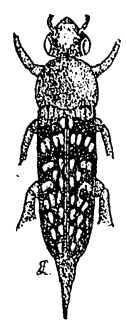

Fig. 22

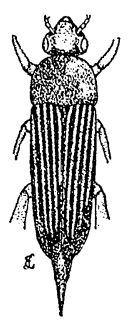

Fig. 23

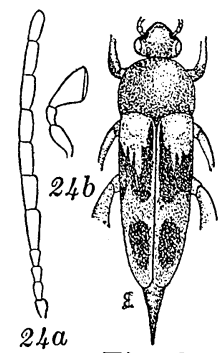

Fig. 24

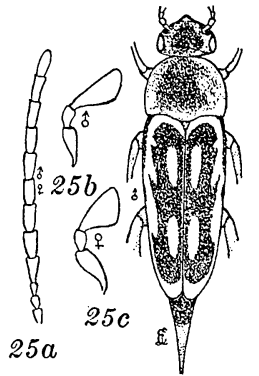

Fig. 25

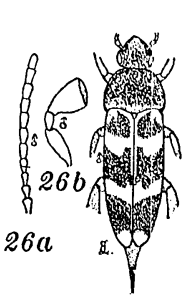

Fig. 26

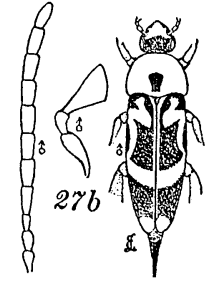

$2 \% a$

Fig. 27

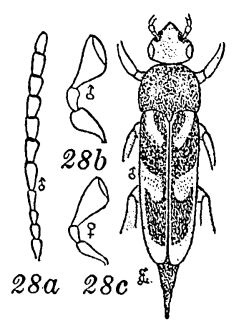

Fig. 28

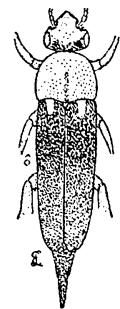

Fig. 29

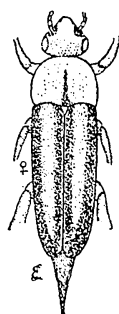

Fig. 30 


\section{PLATE VI}

FIG. 1. Mordellistena fuscipennis Melsheimer.

a. Antennae of male.

b. Maxillary palpi of male.

c. Posterior leg.

FIG. 2. Mordellistena leporina Leconte.

a. Antennae of male.

b. Antennae of female.

c. Maxillary palpi of male.

d. Posterior leg.

FIG. 3. Mordellistena masoni Liljeblad.

FIG. 4. Mordellistena gigas Liljeblad.

a. Antennae.

b. Maxillary palpi.

FIG. 5. Mordellistena incommunis Liljeblad.

a. Antennae of male.

b. Maxillary palpi of male.

c. Posterior leg.

FIG. 6. Mordellistena attenuata Say.

FIG. 7. Mordellistena husseyi, new species.

a. Antennae of male.

$b$. Maxillary palpi of male.

c. Posterior leg.

FIG. 8. Mordellistena unicolor Leconte.

a. Antennae of male.

b. Maxillary palpi of male.

c. Maxillary palpi of female.

FIg. 9. Mordellistena aemula Leconte.

a. Antennae of male.

b. Maxillary palpi of male.

FIG. 10. Mordellistena aethiops Smith.

a. Antennae of male.

$b$. Maxillary palpi of male.

FIG. 11. Mordellistena vera Liljeblad.

a. Antennae of male.

b. Maxillary palpi of male.

Fig. 12. Mordellistena splendens Smith.

a. Anteunae of male.

$b$. Maxillary palpi of male.

FIG. 13. Mordellistena divisa Leconte.

a. Antennae of male.

b. Maxillary palpi of male.

c. Maxillary palpi of female.

FIG. 14. Diclidia greeni Liljeblad.

a. Male appendages.

FIG. 15. Diclidia obscura, new species.

a. Male appendages and genitalia.

FIG. 16. Diclidia laetula Leconte.

a. Male appendages and genitalia.

Fig. 17. Diclidia sexmaculata, new species.

a. Male appendages and genitalia.

FIG. 18. Diclidia propinqua Liljeblad.

FIG. 19. Sphingocephalus ovalis, new species.

a. Antennae of male.

b. Maxillary palpi of male.

c. Labial palpi of male.

d. Male appendages and genitalia. 

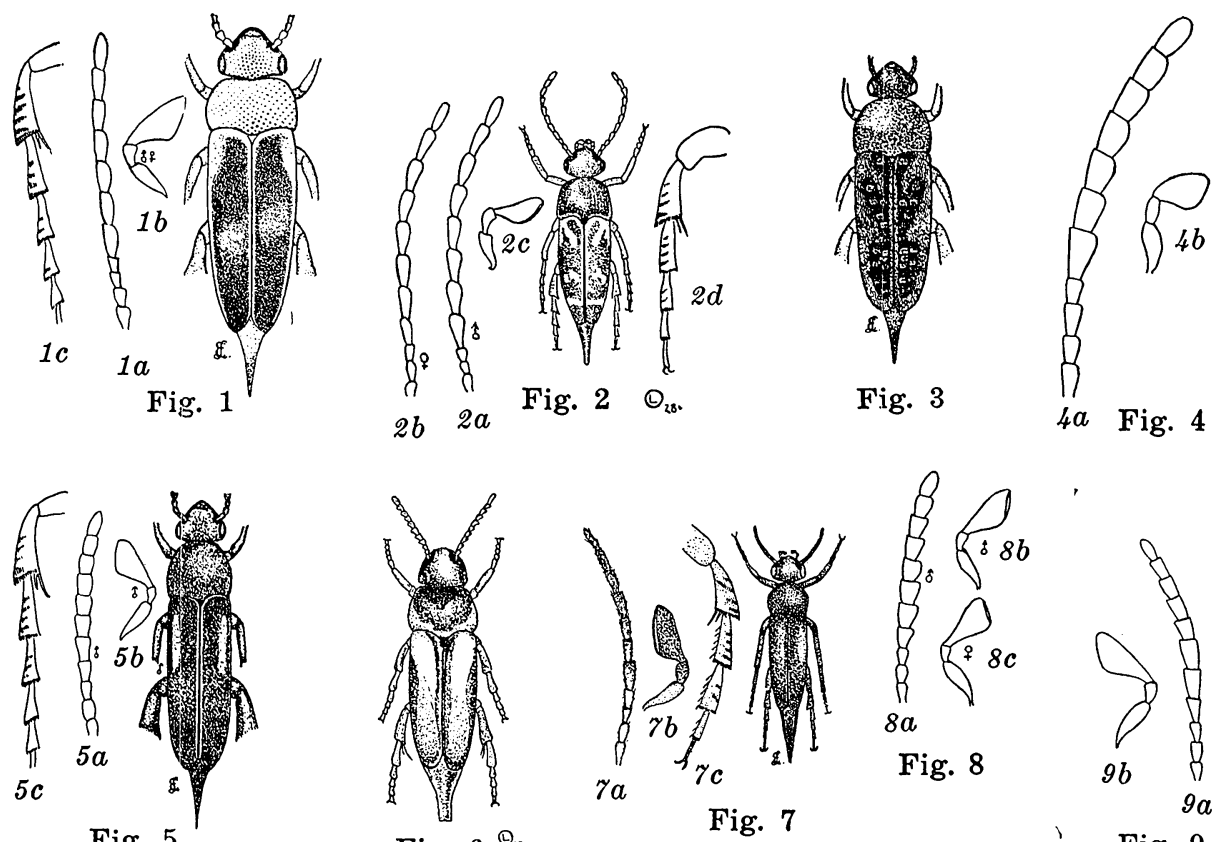

Fig. $6^{\oplus}$

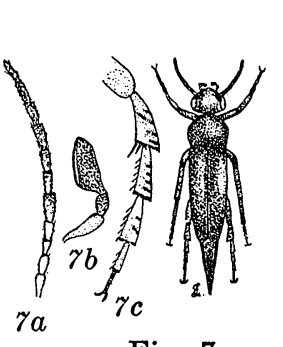

Fig. 7

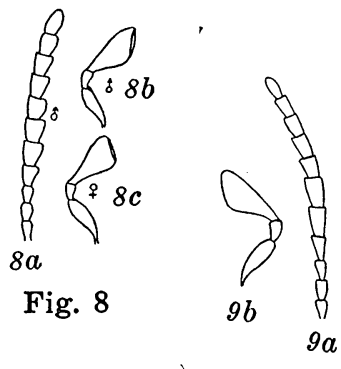

Fig. 9

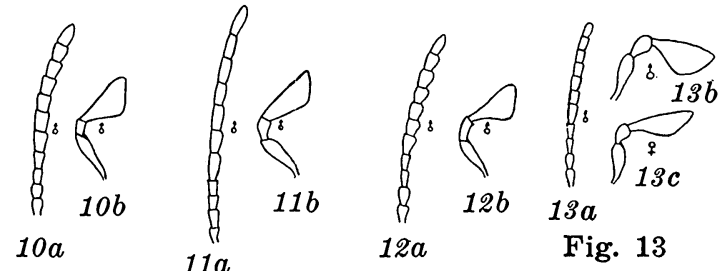

Fig. $10 \quad$ Fig. $11 \quad$ Fig. 12

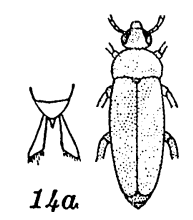

Fig. 14

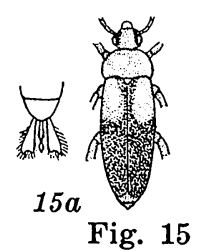

Fig. 15

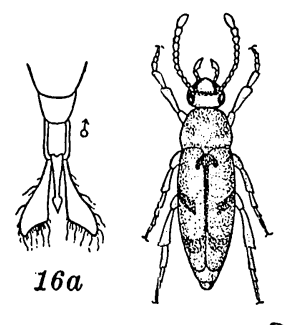

Fig. $16 \stackrel{\mathbb{C}_{22}}{ }$.

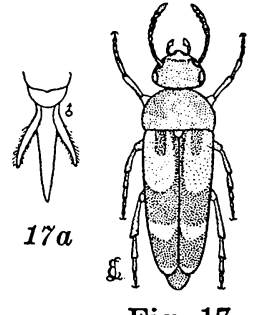

Fig. 17

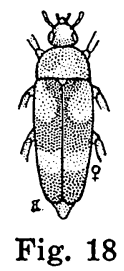

Fig. 18

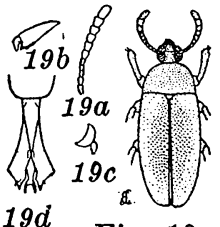

$19 d$ Fig. 19 


\section{PLATE VII}

FIg. 1. Pentaria trifasciatus var. trifasciatus Melsheimer.

FIg. 2. Pentaria trifasciatus var. nubila Leconte.

FIg. 3. Pentaria dispar Liljeblad.

a. Male appendages and genitalia.

Fig. 4. Naucles pusio Leconte.

a. Antennae.

b. Maxillary palpi.

c. Male genitalia.

Fig. 5. Naucles basalis Champion.
a. Antennae.
b. Maxillary palpi.
c. Labial palpi.

FIG. 6. Anaspis atrata Champion.
a. Antennae male.
b. Maxillary palpi of male.

FIG. 7. Anaspis seposita, new species. Abdomen, position of appendages.

a. Side view of appendage.

FIg. 8. Anaspis sericea Mannerheim. Abdomen, position of male appendages.

Frg. 9. Anaspis flavipennis Haldeman. Abdomen, position of male appendages.

a. Antennae of male.

b. Maxillary palpi of male.

FIG. 10. Anaspis militaris Smith.
a. Antennae.
b. Maxillary palpi.

FIG. 11. Anaspis duryi, new species. Abdomen, position of male appendages.

a. Side view of appendage.

Fig. 12. Anaspis beardsleyi, new species. Abdomen, position of male appendages.

a. Antennae male.

b. Maxillary palpi of male.

Frg. 13. Anaspis collaris Leconte. Abdomen, position of male appendages.

a. Antennae of male.

FIG. 14. Anaspis rufa Say. Abdomen, position of male appendages.

a. Antennae male.

b. Maxillary palpi of male.

o. Side view of abdomen, the two appendages from the third and fourth segments. 


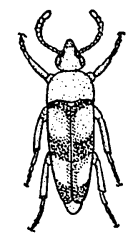

Fig. 1

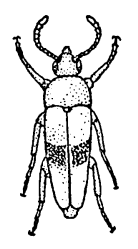

Fig. 2

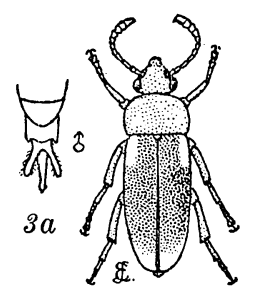

Fig. 3

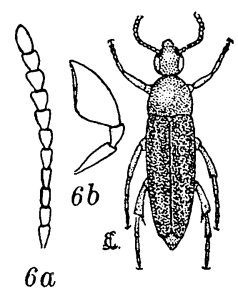

Fig. 6

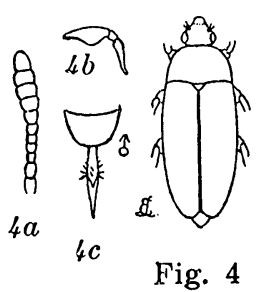

Fig. 7
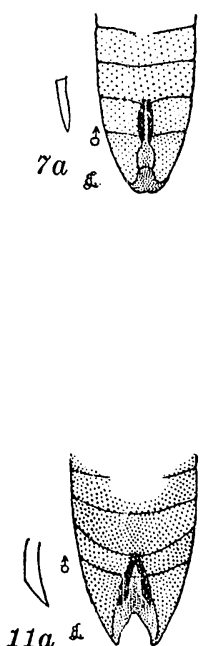

Fig. 11

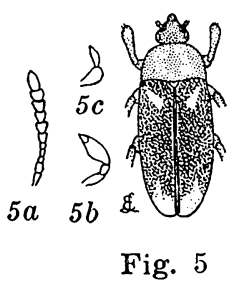

Fig. 9

\begin{abstract}
Fig. 8
\end{abstract}
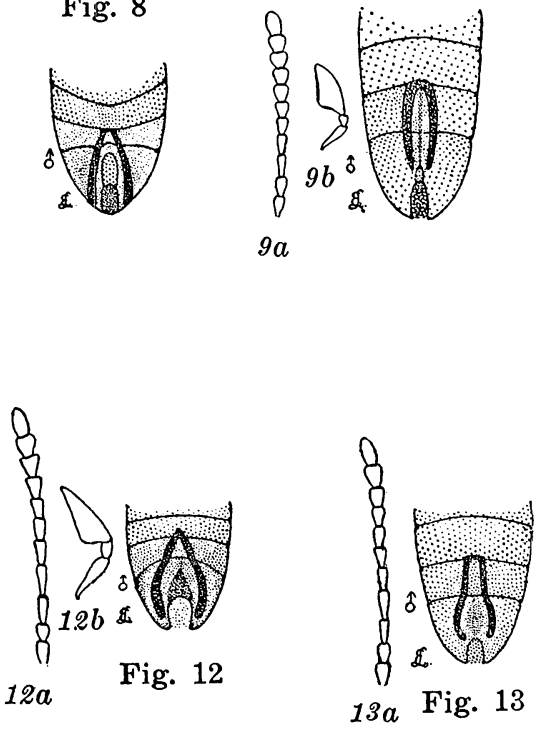

Fig. 10
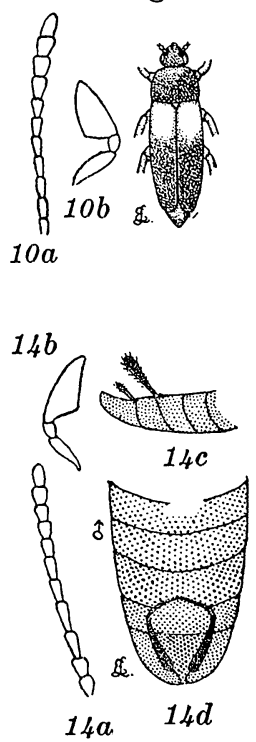

Fig. 14 
$$
\text { . }
$$ 


\section{INDEX OF GENERA AND SPECIES}

aculeata, 30

aemula, 186

aequalis, 174

aethiops, 179

albosuturalis, 50

ambusta, 161

amica, 83

ANASPIS, 207

ancilla, 125

andreae, 123

andreae var. ancilla, 125

andreae var. andreae, 125

andreae var. ustulata, 126

angulata, 42

angusta, 184

ANTHOBATES, 196

Anthobatula, 196

argenteola, 104

arida, 8

aspersa, 111

atra, 209

atrata (Anaspis), 209

atrata (Mordella), 45

atrata var. lecontei, 47

atriceps, 97

attenuata, 184

auricoma, 109

badia, 164

basalis, 205

baudii, 17

beardsleyi, 214

bicinctella, 76

bicolor, 199

bidentata, 26

biguttata, 54

bihamata, 152

biplagiata, 87

bipustulata, 97

blandula, 160

blatchleyi, 133

borealis, 57

brevistylis, 41

bucephala, 54

caliginosa, 158

capillosa, 35 carinata, 65

cervicalis, 109

cinereoatra, 41

cinereo-fasciata, 149

collaris, 215

comata, 108

CONALIA, 16

conformis, 175

confusa, 78

convicta, 146

crinita, 136

decorella, 102

delicatula, 130

deserta, 49

DICLIDIA, 187

dimidiata (Anaspis), 217

dimidiata (Mordellistena), 91

discoidea, 66

discoidea var. flaviventris, 67

discolor, 149

dispar, 199

divisa, 168

duryi, 216

ebenina, 18

egregia, 107

elegantula, 90

elegantulus, 90

errans, 98

erratica, 18

exilis, 109

falli, 86

fasciata, 54

fascifera, 60

ferruginoides, 135

festiva, 86

filiformis, 217

flavipennis, 213

flaviventris, 67

floridensis, 140

frosti, 77

fulvicollis, 95

fusca, 177

fuscata, 177

fuscipennis, 162 
fusco-atra, 183

fuscocinerea, 47

fuscula, 200

gigas, 182

gilva, 194

GLIPA, 20

GLIPODES, 14

grammica, 123

grandis, 52

greeni, 192

guttulata, 129

HALLOMENUS, 208

hebraica, 154

helva, 17

hieroglyphica, 22

hilaris, 22

hirsuta, 201

hirticula, 148

hoosieri, 181

hoppingi, 222

hubbsi, 51

husseyi, 176

immaculata, 49

impatiens, 130

inclusa, 56

incommunis, 175

indistincta, 111

infima, 122

inflammata, 28

inornata, 118

insolita, 180

insulata, 43

intermixta, 97

invisitata, 48

inyoensis, 194

irrorata, 47

ISOTRILOPHUS, 18

jovialis, 23

knausi, 82

knulli, 32

laetula, 188

LARISIA, 220

lecontei, 47

lepidula, 83 leporina, 170

limbalis, 89

lineata, 45

lineella, 58

liturata, 155

lodingi, 173

lunulata, 37

lutea, 80

luteipennis, 212

marginalis, 167

marginata, 44

marginata var. lineata, 45

masoni, 178

melaena, 39

militaris (Anaspis), 214

militaris (Mordellistena), 104

minuta, 119

minutalis, 121

modesta, 150

MORDELLA, 30

MORDELLISTENA, 68

morula, 142

NASSIPA, 222

NAUCLES, 202

nebulosa, 101

nigella, 116

nigerrima, 131

nigra, 208

nigricans, 131

nigriceps, 217

nigricollis, 83

nigricolor, 221

nigrina, 208

nubila, 138

nunenmacheri, 143

obliqua, 38

obscura, 191

octopunctata, 25

oculata, 23

ornata, 101

ovalis, 206

pallens, 118

pallescens, 217

pallida, 201

pallipes, 99

palmi, 159

paradisa, 94 
parva, 133

pauxilla, 93

pectoralis, 102

PENTARIA, 196

perlineata, 29

picicornis, 109

picilabris, 120

picipennis, 99

pityptera, 162

pratensis, 98

propinqua, 190

proxima, 157

pubescens (Mordella), 150

pubescens (Mordellistena), 150

pulchra, 157

pulchra var. proxima, 157

pullata, 115

pusio, 203

pustulata, 144

quadrinotata, 128

quadripunctata, 35

quercus, 205

revelstokei, 219

lubrifascia, 113

rubrilabris, 114

rufa (Anaspis), 217

rufa (Mordellistena), 141

rufescens, 178

ruficeps, 137

rufilabris, 113

rufiventris, 183

rutila, 81

scalaris, 149

scapularis, 87

schauppi, 172

schwarzi, 34

scutellaris, 45

semiusta, 127

seposita, 211

sericans (Glipodes), 15

sericans (Mordellistena), 169

sericea, 212 serval, 62

sexmaculata, 189

sexnotata, 86

signata, 33

SILARIA, 219

singularis, 165

smithi, 142

sordida, 195

SPHALERA, 30

SPHINGOCEPHALUS, 206

spinea, 193

splendens, 139

subfucus, 134

suspecta, 148

suturella, 181

syntaenia, 106

tantula, 159

tar'salis, 78

testacea, 135

texana, 180

tibialis, 204

TOMOXIA, 54

tosta, 117

trifasciata (Mordellistena), 83

trifasciata (Pentaria), 197

trifasciata var. nubila, 198

trifasciata var. trifasciata, 197

triloba, 63

undulata, 61

unicolor, 165

ustulata, 126

vapida, 96

varians, 125

ventralis, 217

vera, 172

vilis, 92

viridescens, 78

vittigera, 184

wenzeli, 79

wickhami, 135

wolcotti, 149 

No. 24. A Comparative Life History Study of the Mice of the Genus Peromyscus. By A.RThur Svihua. (1932) Pp. 39

No. 25. The Moose of Isle Royale. By AdoLPH Murie. (1934) Pp. 44, 7 plates $\$ 0.70$

No. 26. Mammals from Guatemala and British Honduras. By AdoLPH MurIE. (1935) Pp. 30, 1 plate, 1 map insert

No. 27. The Birds of Northern Petén, Guatemala. By Josselyn VAN Tyne. (1935) Pp. 46, 2 plates, 1 map

No. 28. Fresh-water Fishes Collected in British Honduras and Guatemala. By CARL L. HUBBS. (1935). Pp. 22, 4 plates, 1 map ................................................

No. 29. A Contribution to a Knowledge of the Herpetology of a Portion of the Savanna Region of Central Petén, Guatemala. By L. C. STUART. (1935) Pp. 56, 4 plates, 1 figure, 1 map

No. 30. The Darters of the Genera Hololepis and Villora. By CARL L. HuBBs and MotT DWIGHT Cannon. (1935) Pp. 93, 3 plates, 1 figure ............. No. 31. Coniobasis of the Coosa River, Alabama. By Calvin GoodricH. (1936)
Pp. 60, 1 plate, 1 figure

No. 32. Following Fox Trails. By AdolPH MuRIE. (1936) Pp. 45, 6 plates, 6 figures

No. 33. The Discovery of the Nest of the Colima Warbler (Vermivora crissalis). By Josselyn VaN TxNe. (1936) Pp. 11, colored frontis., 3 plates, 1 map

No. 34. Mollusca of Petén and North Alta Vera Paz, Guatemala. By CaLviN GOODRICH AND HENRY VAN DER SCHALIE. (1937) Pp. 50, 1 plate, 1 figure, 1 map

\section{$\$ 0.50$}

No. 35. A Revision of the Lamprey Genus Ichthyomyzon. By CARL L. HUBBS AND Minton B. Trautman. (1937) Pp. 109, 2 plates, 5 figures, 1 map ......

No. 36. A Review of the Dragonflies of the Genera Neurocordulia and Platycordulia. By C. Francis Brens. (1937) Pp. 36, 8 plates, 4 maps ...........

No. 37. The Birds of Brewster County, Texas. By Josselyn VAN TyNe AND GeORGE MIKSCH SUTTON. (1937) Pp. 115, colored frontis., 5 plates, 1 map

No. 38. Revision of Sciurus variegatoides, a Species of Central American Squirrel. By WilliaM P. HARRIs, JR. (1937) Pp. 42, 3 plates (2 colored), 3 figures, 1 map

\section{$\$ 0.50$}

No. 39. Faunal Relationships and Geographic Distribution of Mammals in Sonora, Mexico. By William H. Burt. (1938) Pp. 77, 26 maps ...... $\$ 0.75$

No. 40. The Naiad Fauna of the Huron River, in Southeastern Michigan. By HENRY VAN DER SCHALIE. (1938) Pp. 83, 12 plates, 28 figures, 18 maps .

No. 41. The Life History of Henslow's Sparrow, Passerherbulus henslowi (Audubon). By A. SIDNeY HYDE. (1939) Pp. 72, 4 plates, 3 figures, 1 map $\$ 0.75$

No. 42. Studies of the Fishes of the Order Cyprinodontes. XVI. A Revision of the Goodeidae. By Carl L. Hubbs and C. L. Turner. (1939)'

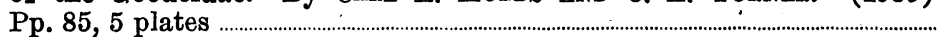

No.43. Aquatic Mollusks of the Upper Peninsula of Michigan. By CALviN GOODRICH AND HENRY VAN DER SCHALIE. (1939) Pp. 45, 2 maps ............

No. 44. The Birds of Buckeye Lake, Ohio. By Muton B. Tradtman. (1940) Pp. 466, 15 plates and a frontis., 2 maps ........................................................

No. 45. Territorial Behavior and Populations of Some Small Mammals in South-
ern Michigan. By WILLIAM H. BuRT. (1940) Pp. 58, 2 plates, 8

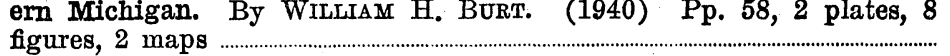

No.46. A Contribution to the Fcology and Faunal Relationships of the Mammals of the Davis Mountain Region, Southwestern Texas. By W. Frank Blarr. (1940) Pp. 39, 3 plates, 1 map ............................................

No.47. A Contribution to the Herpetology of the Isthmus of Tehuantepec. IV. By Norman HARTWEg AND James A. OuIVer. (1940) Pp. 31 ................
Revision of the Black Basses (Micropterus and Huro) with Descrip-

No. 48. A Revision of the Black Basses (Micropterus and Huro) with Descrip-
tions of Four New Forms. By CARL L. HUBBS AND REEVE M. BAILEY. (1940) Pp. 51, 6 plates, 1 figure, 2 maps 
No. 49. Studies on Neotropical Colubrinae. VIII. A Revision of the Genus Dryadophis Stuart. By L. C. STUART. (1941) Pp. 106, 4 plates, 13 figures, 4 maps

No. 50. A Contribution to the Knowledge of Variation in Opheodrys vernalis (Harlan), with the Description of a New Subspecies. By ARNoud B. GrobmaN. (1941) Pp. 37, 2 figures, 1 map

No. 51. Mammals of the Lava Fields and Adjoining Areas in Valencia County, New Mexico. By EMMeT T. Hooper. (1941) Pp. 47, 3 plates, 1 map. $\$ 0.50$

No: 52. Type Localities of Pocket Gophers of the Genus Thomomys. By Eмmet T. HOOPER. (1941) Pp. 26, 1 map

No. 53. The Crane Flies (Tipulidae) of the George Reserve, Michigan. By J. SPEED Rogers. (1942) Pp. 128, 8 plates, 1 map

No. 54. The Ecology of the Orthoptera and Dermaptera of the George Reserve, Michigan. By IRving J. CANTRALL. (1942) Pp. 182, 10 plates, 2 maps

No. 55. Birds from the Gulf Lowlands of Southern Mexico. By PIERCE BrodKORB. (1943) Pp. 88, 1 map

No. 56. Taxonomic and Geographic Comments on Guatemalan Salamanders of the Genus Oedipus. By L. C. Stuart. (1943) Pp. 33, 2 plates, 1 map

No.57. The Amnicolidae of Michigan: Distribution, Ecology, and Taxonomy. By Elmer G. Berry. (1943) Pp. 68, 9 plates, 10 figures, 10 maps ........

No.58. A Systematic Review of the Neotropical Water Rats of the Genus Nectomys (Cricetinae). By PhiliP Hershkovitz. (1943) Pp. 88 4 plates, 5 figures, 2 maps

No. 59. San Francisco Bay as a Factor Influencing Speciation in Rodents. By

EMMET T. Hooper. (1943) Pp. 89, 5 plates, 18 maps ...............................
No. 60. The Fresh-Water Triclads of Michigan. By Roman KeNK. (1943) Pp. 44, 7 plates, 5 figures.

No.61. Home Range, Homing Behavior, and Migration in Turtles. By FRED R. CAGLE. (1944) Pp. 34, 2 plates, 4 figures, 1 map

No. 62. Monograph of the Family Mordellidae (Coleoptera) of North America, North of Mexico. By EMIL LILJEBlad. (1945) Pp. 226, 7 plates .......... \$2.00

Price lists are available for the Occasional Papers, Handbook Series, and Circulars of the Museum of Zoology. 